\author{
UNIVERSIDADE DE SÃO PAULO \\ FACULDADE DE FILOSOFIA, LETRAS E CIÊNCIAS HUMANAS \\ DEPARTAMENTO DE FILOSOFIA \\ PROGRAMA DE PÓS-GRADUAÇÃO EM FILOSOFIA
}

ALEXANDRE FILORDI DE CARVALHO

HISTÓRIA E SUBJETIVIDADE

NO PENSAMENTO DE MICHEL FOUCAULT

SÃO PAULO - SP 
ALEXANDRE FILORDI DE CARVALHO

\section{HISTÓRIA E SUBJETIVIDADE \\ NO PENSAMENTO DE MICHEL FOUCAULT}

Tese apresentada ao Departamento de Filosofia da Faculdade de Filosofia, Letras e Ciências Humanas da Universidade de São Paulo, sob a orientação da Prof $^{\mathrm{a}} \mathrm{Dr}^{\mathrm{a}}$ Scarlett Z. Marton, como requisito parcial para obtenção de título de Doutor em Filosofia.

De acordo:

Prof $^{\mathrm{a}} \mathrm{Dr}^{\mathrm{a}}$ Scarlett Z. Marton

São Paulo, agosto de 2007 
DEDICATÓRIA

Este trabalho é dedicado à memória de

Maria T. Pereira Alves, em quem tudo começou. 


\section{AGRADECIMENTOS}

À Scarlett Marton, pela impecável orientação, presença intelectual, incentivo e amizade.

Aos amigos e amigas do GEN, espalhados por todo Brasil, pelas discussões, companheirismo e cumplicidade.

Ao Carlos Eduardo Ribeiro, amigo e companheiro próximo na partilha foucaultiana.

À Mariana Barbosa Corrêa Filordi de Carvalho, que soube entender, esperar e agir ao longo de toda esta vereda.

Ao Tarcísio, Marli, Daniella, Camila, Samuel, Lívia, Enrico, José, Lourdes e Suzana - a grande família.

Ao Edson Furlan e Natercia Beer Furlan, as pessoas mais afetuosas e iluminadas que já conheci.

Ao Henk e Gérard, mais do que amigos mesmo além-mar.

Ao Conselho Nacional de Desenvolvimento Científico e Tecnológico - CNPq, pelo apoio financeiro recebido ao longo do desenvolvimento da pesquisa. 
Connais-tu, comme moi, la douleur savoureuse, Et de toi fais-tu dire: “Oh! l'homme singulier!”

(Conheces tu, como eu, essa dor saborosa, E que te faz dizer: "Oh, o homem singular!")

Baudelaire As flores do mal

Todos estão loucos, neste mundo? Porque a cabeça da gente é uma só, e as coisas que há e que estão para haver são demais de muitas, muito maiores diferentes, $e$ a gente tem de necessitar de aumentar a cabeça, para o total.

"Riobaldo" Grande sertão: veredas 


\section{RESUMO}

CARVALHO, A. F. de. História e subjetividade no pensamento de Michel Foucault. 2007. 242 f. Tese (Doutorado) - Faculdade de Filosofia, Letras e Ciências Humanas. Departamento de Filosofia, Universidade de São Paulo, São Paulo, 2007.

Defendemos que a problemática do sujeito recobre globalmente a trajetória do pensamento de Michel Foucault. As transformações atinentes a este campo não podem ser apreendidas e demonstradas a não ser pelo entendimento das distintas maneiras e abordagens dispensadas a uma série de empreendimentos históricos, cujo cerne é a da descontinuidade. Entendemos que o constante esforço de modificação no exercício e domínio da história tem por objetivo colocar em evidência os campos e níveis heterogêneos de problematizações, transformações e experiências nas quais o sujeito tem a sua constituição. Para tanto, ficará demonstrado que a crítica ocupa lugar central, por um lado, no registro metodológico como caminho de constante reposicionamento do pensamento que se debruça sobre a relação história e sujeito, notadamente nas dimensões arqueológica e genealógica. Por outro, no registro dos lugaresdiscursos-práticas das experiências que são recobertas essencialmente por relações de forças nos processos históricos, cujas estratégias se voltam para o sujeito enquanto término de formas de sujeição, e cujo centro de transformação dessas relações evoca o enfrentamento enquanto acontecimento histórico para a constituição de processos de dessujeição ou de um sujeito ativo. Sempre no âmbito da história enquanto problematização e acontecimento, o sujeito irá tornar-se experiência histórica aberta. Isto, além de colocar em xeque as condições de seu destino, seu ser e estar na história, conduz-nos à análise das atitudes-experimentais possíveis a ele como força de criação ou produção de si mesmo. Modificar a si mesmo é modificar a história; modificar a história é modificar a si mesmo.

\section{PALAVRAS-CHAVE}

História; subjetividade; sujeito, relações de forças; poder-saber; crítica. 


\begin{abstract}
CARVALHO, A. F. de. History and Subjectivity in the Thinking of Michel Foucault. 2007. 242 f. Thesis (Doctoral) - Faculdade de Filosofia, Letras e Ciências Humanas. Departamento de Filosofia, Universidade de São Paulo, São Paulo, 2007.
\end{abstract}

We support the idea that the problem of the subject covers the whole pathway of Michel Foucault's thinking. The changes concerning this field cannot be grasped and conveyed except by understanding the different ways and approaches directed to a series of works of historic engagement whose core is the question of discontinuity. We understand that the constant effort to change in the course of history aims at bringing forth the different fields and levels of approach, changes and experiences that build up the subject. In this respect it will be shown that criticism plays a central part in this project. On the one hand in a methodological key as a way of constant repositioning of the thinking that focuses on the relationship between history and the subject, especially in archaeological and the genealogical dimension. On the other hand, in the key of the places/discourses/practices of the experiences that are essencially coveredby relations of power in the historic process whose strategies are directed to the subject as the end of the forms of subjugation, and in which the center of change in these relationships evokes conflict as a historic factor for the constitution of a liberation process and of an active subject. Always in the view of history as questioning and achievement, the subject is bound to become an open historic experience. This, besides questioning the conditions of his destiny and his position in history, leads us to an analysis of the experimental attitudes in his reach as a force for creating himself in history. Changing himself is changing history; changing history is changing himself.

\title{
KEY-WORDS
}

History; subject; subjectivity; relations of power; power-knowledge; criticism 


\section{SUMÁRIO}

Introdução

I. A história como espetáculo do mundo

1.1 Multiplicidades: figuras históricas em espaços de dispersão

1.2 Campos de problematizações, campos de transformações

1.3 História crítica do pensamento

II. Para uma arqueogenealogia: o método de Foucault

2.1 Arqueologia

2.2 Genealogia

III. As relações de forças nos processos históricos de constituição de subjetividades

3.1 O campo das situações estratégicas para o entendimento das subjetividades

3.2 As relações de forças na produção de subjetividades

3.3 Das técnicas às tecnologias políticas: o uso e aplicação das forças nos processos de sujeição

3.4 Acontecimento e dessujeição: a constituição do sujeito da ação ou a força produtiva de si

Conclusão

Bibliografia 


\section{INTRODUÇÃO}

\section{Não existem fatos eternos: assim como não existem verdades absolutas. - Portanto o filosofar histórico é doravante necessário, e com ele a virtude da modéstia.}

Friedrich Nietzsche, Humano, demasiado humano

Destituído de uma assinatura definida e portador de uma discursividade heterogênea às suas transformações ulteriores, donde um amplo número de possibilidades incertas de aplicações se sucede, o trabalho de Michel Foucault faz explodir incontáveis feixes de problematizações. $\mathrm{O}$ alvo das investigações seguintes está focalizado no encaminhamento de determinadas questões decisivas: como abordar um pensamento talhado numa tensão constante, cujas linhas temáticas são movediças a ponto de criar rupturas e distanciamentos temáticos tão múltiplos e que, ao mesmo tempo, compõem uma obra? Em função de todas as oscilações presentes na obra, qual a relevância e implicância que a história exerce em um pensamento de calibre filosófico, a que veio o pensamento de Foucault nitidamente cortado por um trabalho de ênfase histórica? E qual o seu alcance nos limites desta especificidade? Enfim, sob condições de análises históricas assumidamente descontínuas, quais seriam as conseqüências se buscássemos um tipo de problema em prospecção? Seria mesmo isto possível? A fim de quê?

Concernente à obra, sustentamos que todo trabalho exegético e interpretativo consignado a ela advém de certas opções de "entrada" no delineamento de seu campo. Isto é determinante quanto à nossa abordagem. De sua explicitação, qualquer plausibilidade é fiadora. De saída, é preciso mencionar e reconhecer que, em nosso caso, obra não sugere unidade de escrita, nem unidade estilística ou temática. Não pretende autenticar certos resultados de um discurso individual, homogêneo e de filiação identificadora, pois é uma constante abertura de espaço onde "o sujeito escritor não cessa de desaparecer". Foucault destrói a idéia ordinária de obra para fazer circular uma crítica inicial aos espaços definidores de saber. Que importa quem fala? De onde fala? Como fala?

Não é somente pelo fato de nos depararmos com um princípio organizador instável que a questão se coloca: qual nível de coerência é possível exigir de um percurso de 
pensamento travado na multitude composta de "entrevistas, prefácios, conferências, cursos", como bem assinala Chartier ${ }^{1}$, além é claro de, ainda, inéditos, traduções e títulos publicados convencionalmente? É certo que, nestas condições, não é difícil de enxergar a ausência nítida de coerência, o que teria feito Habermas argumentar que o pensamento foucaultiano é o da "contradição instrutiva", ou melhor, da "contradição produtiva", Mas não nos ofereceria este estatuto da obra e sua própria estrutura uma margem de alcance para além da contradição, isto é, implodindo mesmo todo ideal de sistematicidade? Neste aspecto, é preciso pensarmos com a força do argumento. Acaso, em termos de obra, linearidade, continuidade e unidade são condições sine qua non de uma coerência?

"Uma coerência difícil", nos termos de Judith Revel, é claro, não implica necessariamente em inviabilidade. É preciso, contudo, assumir a ordem nada evidente que há no percurso do pensamento de Foucault. Os problemas e questões decorrentes disto fazem, justamente, a composição de profundidade de um jogo fractal que não pretende reduzir ou esgotar as múltiplas possibilidades de investigação conceituais que a obra pode comportar. Mas, apesar de caminharmos nesta direção, ainda persiste um nódulo não solvente de seu percurso, a saber. Se levarmos em consideração três blocos de produção intelectual, simplesmente de modo didático: década de 1960, década de 70 e anos 80; uma questão crucial emerge. Noções e conceitos tão díspares como o de épistétemè, acontecimento, transformação, problematização, práticas, governamentalidade, governo de si e cuidado de si, por exemplo, devem ser tratados como? Há uma superação? Há um esquecimento e repressão de um termo ao outro? Há uma contradição que se impõe entre um pensamento que aceita a determinação de um saber invisível e poderoso na formação das ações e comportamentos humanos, portanto limitador, e um que evoca as práticas individuais como contra-força do estabelecido? Enfim, o tratamento da obra não deixa de ser problemático mesmo quando aceitamos que as suas "cadeias de variáveis", sob a atenção de Deleuze, são imanentes ao pensamento de Foucault.

Nestes termos, se assumirmos as rupturas, precisamos buscar um entendimento que não viabilize um impasse interpretativo. Para tanto, sustentaremos que a própria obra, e esta leitura, a nosso ver, não pode ser forjada numa cronologia crescente, mas sim numa ordem lógica de termos que se explicitam, às vezes, de trás para frente, ou seja, de expressões já maturadas no percurso genealógico incidindo na etapa arqueológica como eco conseqüente e

\footnotetext{
${ }^{1}$ CHARTIER, R. Au bord de la falaise: L'histoire entre certitudes et inquiétude, p.191.

${ }^{2}$ HABERMAS, J. Une fleche dans le coeur du temps présent. In. Critique - Michel Foucault du monde entier, $\mathrm{N}^{\circ} 471-472,1986$, p.799.
} 
desdobrável de uma base que se alargou com a estrutura, configura-se, assim, efeito específico do pensamento de Michel Foucault. Por conseguinte, a sua filosofia, antes de tratar de um feixe discursivo-conceitual e de plasmar determinados empreendimentos, encontra-se, em sua forma, reflexos de questões que o seu pensamento alcança, funda, explora e desdobra. Concernente a isto, caberá a nós evidenciar que a "revolução" que Foucault faz na história, na indicação de Veyne, é atestada pelas próprias torções e disjunções presentes no percurso de sua produção. E mais, disto encontramos um transbordamento de questões que vão se aprofundando, enraizando-se de modo rizomático, marginalizando-se, pois a todo instante o epicentro se modifica, distendendo, assim, o campo erodido de um pensamento. Mas como? Por quê?

O punctum saliens, a nosso ver, é a questão descontinuidade que opera em três níveis. Primeiro, a obra quebra uma identidade absoluta de uma linearidade lógica. Afastando-se de um modelo evidente de progressão de pensamento, deparamo-nos, como bem nos fez enxergar Judith Revel, com uma "coerência não linear; melhor, uma coerência precisamente devido à crítica da linearidade, que refuta a identidade, com a intenção de não produzir uma unidade" 3 . Desta maneira, a diversidade temática impede uma unidade, mas, mesmo em planos múltiplos, não desabona uma coerência. Lógico, é preciso lembrar que estamos diante do filósofo que usa a desordem da palavra contra a ordem do discurso. Ademais, não podemos esquecer que Foucault vai além de todo e qualquer caráter sólido e estático dos conceitos consagrados, o que não exclui a própria acepção de obra. Mas, com isto, os conceitos tornamse operadores, instrumentos de pensamento. Entender o "gesto verbal" foucaultiano, para nos valermos da excelente expressão de Butler, é levar em conta os golpes desferidos pela força de um pensamento que, ciente da finitude do saber, por vezes, utiliza termos já consagrados e bem situados na história do pensamento ocidental justamente para livrá-los das amarras da discursividade. Então é preciso mostrar que o filósofo age "por uma manipulação hábil que livra os termos de suas coações discursivas habituais, da pretensão que só se pode pronunciar um termo sabendo por antecipação qual deve ser sua ancoragem" ${ }^{\text {"4 }}$. Contudo, isto não significa que ele faça valer uma sorte de "arte retórica", como pretendem Dreyfus e Rabinow $^{5}$, porém muito mais uma técnica de um franco-falar que se engaja numa

\footnotetext{
${ }^{3}$ REVEL, J. Expérience de la penspée: Michel Foucault. Paris: Bordas, 2005, p.26.

${ }^{4}$ BUTLER, J. Qu'est-ce que la critique? Essai sur la vertu selon Foucault. Paris: Karthala, 2005, p.98.

${ }^{5}$ DREYFUS, H. L. e RABINOW, P. Habermas et Foucault - Qu'est-ce que l'age d'homme ? In. Critique Michel Foucault du monde entier, n.471-472, 1986, p.854-872. A expressão é retirada do seguinte trecho: "O avanço interpretativo organizado por Foucault consiste em identificar o que, a seus olhos, constitui nosso problema atual; descrever, sem embaraço, como esta situação se apresentou, usando de sua arte retórica para
} 
especificidade de saber e de ordem política advinda do pensamento, que encontraremos sua mais profunda modalidade e alcance em sua trajetória dos anos $80^{6}$.

Segundo, é forçoso estarmos atentos para a seguinte questão: é evidente que nenhum tipo de método consagrado poderia urdir o aspecto fractal da obra. Se há, também, uma descontinuidade entre arqueologia e genealogia, como seria possível tomar o conjunto de seu percurso como objeto de investigação sem fazer ressaltar as diferenças de objetos que os métodos acampam? E mais, tais diferenças distanciam as temáticas pertinentes a cada tipo metodológico ou são capazes de aproximá-las? Quais conseqüências são advindas desta dinâmica? Será forçoso demonstrar que arqueologia e genealogia se organizam em torno de uma tensão constitutiva nos elementos de um método. Contudo não deixam de transparecer certo "fio vermelho", em filigrana, que torna cada vez mais vertiginosa e evidente a descontinuidade presente no pensamento e na história do Ocidente. Por conseguinte, a manière de faire de Foucault não é "nem um postulado, nem um resultado"7 que justificariam as rupturas, transições ou negações contidas entre etapa arqueológica ou genealógica. Os motivos de mudanças metodológicas estão mais no sentido de uma dilatação de problematizações. Evidente que é o nosso working progress definir quais são. Vale, contudo, ressaltar, uma outra vez nos valendo da preciosa argumentação de Judith Revel, que, "antes de ser genealógico, o pensamento foucaultiano é descontínuo - ou mais exatamente, é a descontinuidade que torna inevitável a assunção da dimensão genealógica”. Assim, é forçoso pensarmos em explicitar como uma coerência entre elas, embora problemática, seja possível, uma vez que

se a história genealogicamente dirigida 'intenta fazer aparecer todas as descontinuidades que nos atravessam', ela já está presente em Foucault nos anos de $1960 \mathrm{em}$ forma de uma atenção extrema aos acontecimentos, quer dizer, às quebras temporais que se manifestam em forma de fatos isolados ou através da emergência de novas convergências epistêmicas gerais que se dão sempre no fundo de ruptura. ${ }^{8}$

repercutir e amplificar o mal-estar que ele divide conosco, em face do perigo inoportuno, que sua conclusão nos apresenta." p.865.

${ }^{6}$ Nota bene - Eis, aí, um exemplo da dificuldade que uma interpretação linear possui. O franco-falar, termo explorado a partir da compreensão da parrhysía grega, embora situado na trajetória tardia de Foucault, pode servir como chave de compreensão de um estilo que transborda os limites da formalidade conceitual. Neste registro, quando temos expressões como "liberdade original", "estrutura", "experimentos", "ontologia", precisaremos examiná-las dentro do contexto, por vezes, alheio à história dos conceitos e suas filiações, mas que recebem um tratamento instrumental que fazem valer o pensamento foucaultiano na especificidade de seus termos, o que não deixa de ser um problema para a própria filosofia, notadamente enquanto trabalho conceitual.

${ }^{7}$ REVEL, J. Opus cit, p.38.

${ }^{8}$ REVEL, J. La pensée verticale : une éthique de la problématisation. In. GROS, F. (Org.). Foucault, le courage de la vérité. Paris: PUF, 2002, p.66. 
A julgar pela forma que a descontinuidade se interpõe na trama da obra e do campo metodológico, um terceiro problema emerge munido de grande força: como balizar um pensamento da descontinuidade que, ao mesmo tempo, põe em marcha a descontinuidade do pensamento? Aos poucos, como será necessário evidenciar, vão se armando as dificuldades presentes e características do tratamento específico que Foucault dispensa à história. Se há uma operação arquitetada em favor de um desencantamento da história contínua, que tipo de demarcação axial estaria em voga capaz de realizar tal façanha? E como ela operaria, principalmente sob o registro de uma coesão?

Mas, antes de nos debruçarmos sobre este ponto fulcral, é imprescindível notarmos suas conseqüências preliminares. Dado o estatuto da obra, um aspecto problemático diz respeito ao que podemos designar de problema de filiação filosófica atribuída a Foucault, sem contar as diversas vias de campos disciplinares em que seu pensamento foi, e ainda é, apropriado ${ }^{9}$. A topografia das escolhas interpretativas e filosóficas que alguns intérpretes promanam revelam o tamanho da complexidade da questão. Para Deleuze, Foucault é um "novo arquivista"; Veyne o concebe como o "primeiro historiador a ser completamente positivista", com o que concordará Descombes, não, porém, sem acrescentar ao positivista o termo "niilista". Numa outra perspectiva, Wahl, depois de rejeitar qualquer possibilidade positivista em Foucault, elege-o como um "pragmático". Há aqueles, como Dosse, que não se esqueceram de um Foucault "estruturalista". Para Rajchman, não se trata de nada disto, porém o filósofo francês seria um "cético", mais do que isto, "cético" de cunhagem "nominalista", o que não deixa de encontrar eco nos comentários de Védrine, Davidson e mais uma vez Veyne ao ressaltar o caráter nominalista de Foucault. Outrossim, o filósofo bem que pode ser um pensador vinculado a uma "analítica interpretativa", como querem Dreyfus e Rabinow. ${ }^{10}$

Para além da perspectiva oferecida por meio das mais distintas tentativas de situar as transformações evidentes do pensamento foucaultiano numa singularidade qualquer, deparamo-nos, também, com o problema da herança filosófica encontrada em seu trabalho,

\footnotetext{
${ }^{9}$ Psicanálise, psiquiatria, sociologia, crítica literária ou artística, educação, administração de empresas, são exemplos de campos que se apropriam, ampliam e transformam a obra de Foucault como objeto de múltiplas interpretações e numerosos comentários. Frédéric Gros nos chama a atenção para este aspecto em Michel Foucault, une philosophie de la vérité. In. Michel Foucault, philosophie: antologie. Paris: Gallimard, 2004, p.11.

${ }^{10} \mathrm{O}$ desenvolvimento destas questões, per se, nos permitiria realizar um trabalho de grande fôlego. Todavia tal perspectiva não corresponde ao propósito de nosso intento. Queremos somente chamar a atenção para uma questão que não deixa de ser uma problemática no que tange às abordagens teóricas do pensamento de Foucault. Para nós, o filósofo francês está na vertente antidogmática de pensamento que não comporta nenhuma cunhagem capaz de acampar, que seja de modo sintético ou identitário, o alcance do conjunto de sua obra. Aliás, é bom relevarmos, Foucault tinha consciência de que cada pequena peça de seu mosaico pode dar margens a formas distintas de interpretação, contudo fazia questão de rejeitar qualquer forma de "etiqueta arbitrária", cf. Structuralisme et poststructuralisme. Dits et Écrits IV, $\mathrm{N}^{\circ} 330,1983$, p.431-467.
} 
melhor ainda, do problema da tradição da história da filosofia. As diferenças são tantas que, além de contribuir para a diversidade de aplicações e refletir a diversidade mesmo da obra, colocam para nós, senão em xeque, a viabilidade de uma leitura em conjunto. Trata-se, como bem ressalta Frédéric Gros, de saber "se é possível encontrar um fio vermelho que corta de atravessado o conjunto de sua obra e de recentrá-la em torno de uma interrogação propriamente filosófica" ${ }^{11}$. Concernente a isto, é possível encontrarmos uma discussão acerca de um estofo webberiano em Foucault ${ }^{12}$; da presença marcante de um Marx do livro II de $O$ Capital $^{13}$; um possível relevo marcante e indelével das temáticas associadas à Escola de Frankfurt, notadamente numa abordagem relacionada às questões adornianas ${ }^{14}$ não está descartado. Ademais, não estão afastados “os insuspeitáveis momentos de convergência e de analogia com certos temas hegelianos", conforme a proposta de Fimiani, sobretudo referente à consciência de $\mathrm{si}^{15}$; ainda, segundo a mesma intérprete, é possível “entrever, em filigrana, a persistência - e talvez a preeminência - de uma inspiração kantiana nas diferentes fases de pesquisas conduzidas durante quase trinta anos por Foucault" ${ }^{\prime 16}$. Aliás, a relevância da força de Kant, sobretudo no que tange à constituição da acepção de crítica em seu pensamento, é notada pelos mais diferentes pensadores e dos mais distintos calibres ${ }^{17}$. Numa outra dimensão, como a de Deleuze, é o filósofo da transvaloração, Nietzsche, que é evocado como impressão digital indelével para uma filosofia que pretende superar o anúncio da morte do homem ${ }^{18}$. Finalmente, sem a pretensão de restringir as abordagens, pois a lista comporta outras associações, não podemos deixar de mencionar a evidente associação de Foucault aos mais distintos campos da Filosofia Antiga ${ }^{19}$.

\footnotetext{
${ }^{11}$ GROS, F. Michel Foucault, une philosophie de la vérité. In. Michel Foucault, philosophie: antologie. Paris: Gallimard, 2004, p.11.

12 CLEGG, S. Weber and Foucault: social theory for the study of organizations. In. Organization Articles. London, Vol. 1 (1): p.149-178. O’NEILL, J. The disciplinary society: from Weber to Foucault. In. The British Jounal of Sociology, Vol. XXXVII, N.1. p.42-60.

${ }^{13}$ REVEL, J. Expérience de la pensée: Michel Foucault. Paris: Bordas, 2005.

${ }^{14}$ HONNETH, A. Foucault et Adorno: Deux formes d'une critique de la modernité. In. Critique - Michel Foucault du monde entier, n. 471-472, 1986, 800-815p.

${ }^{15}$ FIMIANI, M. Le véritable amour et le souci commun du monde. In. GROS, F. (Org.). Foucault, le courage de la vérité. Paris: PUF, 2002. p.87-126.

${ }^{16}$ FIMIANI, M. Foucault et Kant: critique, clinique, étique. Paris: L’Harmattan, 1998.

17 BUTLER, J. Qu'est-ce que la critique? Essai sur la vertu selon Foucault. In. GRANJON, Marie-Christine (Org.). Penser avec Michel Foucault - théorie critique et pratiques politiques. Paris: Karthala, 2005. p.75-101; DREYFUS, H. L. e RABINOW, P. Habermas et Foucault: qu'est-ce que l'age d'homme? 857-872. HABERMAS, J. Une flèche dans le coeur du temps présent. In. Critique - Michel Foucault du monde entier, n. 471-472, 1986, p.794-799. Critique - Michel Foucault du monde entier, n. 471-472, 1986,

${ }^{18}$ DELEUZE, G. Foucault. Paris: Les Éditions de Minuit, 1986. Especialmente o anexo entitulado: Sur la mort de l'homme et le surhomme. p.131-141.

${ }^{19}$ Há uma gama de autores que exploram esta temática. De nossa parte, destacamos: HADOT, P. Réflexions sur la notion de "culture de soi". In. Michel Foucault philosophe. Rencontre internationale. Paris 9, 10, 11 janvier 1988. Paris: Seuil, 1989, p.261-270; Exercices spirituels et philosophie antique. Paris: Albin Michel, 1993.
} 
Em que pese todas essas questões quanto ao tratamento interpretativo dispensado à obra de Foucault, é importante sublinhar que a pletora de divergências exegéticas e de propostas de linha de condução temática ocorrem, a nosso ver, pela própria fecundidade do seu pensamento, mas também pela falta de um entendimento e abordagem que por vezes gerarão três deficiências de longo alcance que a nossa pesquisa pretende problematizar. De um lado, temos a própria questão da descontinuidade e de sua recepção como aspecto de importância preponderante, que por vezes não recebe a atenção necessária. Donde, numa outra perspectiva, ocorre uma real dificuldade para se entender as ramificações que interligam a vertente arqueológica de Foucault com a etapa genealógica. Aliás, ao tomá-las por procedimentos distintos e desconexos, muitos intérpretes deram fôlego demasiado a certas questões em detrimento de outras, prejudicando, assim, uma visão e abordagem de conjunto da obra. É comum, desta forma, se pensar que a arqueologia foi superada pela genealogia; que a genealogia resgatou temáticas suprimidas do universo foucaultiano. Não sem sentido, comentadores como Ferry e Renaut podem apostar que os impasses e fissuras na estrutura do pensamento de Foucault fizeram emergir uma espécie de amálgama capaz de servir aos mais variados propósitos e desígnios. Além disto, é claro, surgem núcleos distintos de temáticas que ora se concentram nas questões históricas levantadas por Foucault, ora se concentram numa busca meta-histórica, extrapolando os próprios movimentos internos do conjunto da obra, com a intenção de se forjar uma constelação de temas pouco íntima à sua trajetória. É o que acontece, por exemplo, quando se concentra no eixo das questões genealógicas, como se o filósofo tivesse negado ou rejeitado todo o restante de seu percurso intelectual.

A partir do enquadramento destas questões, a nós nos parece que será vital tomar o próprio pensador, seguindo de perto as ponderações de Chartier, como um "leitor dele mesmo", o que não significa, contudo, que Foucault estivesse "numa situação melhor que a de seus comentadores, sempre divididos entre a evidência enganosa das noções que permitem falar das obras e a radicalidade de rupturas que impõe, ela mesma, ao empreendimento foucaultiano" ${ }^{20}$. Tanto é que o próprio Foucault fez oscilar, por várias vezes, à sua interpretação, séries distintas de vetores temáticos que comporiam o epicentro de uma trajetória, talvez convergente, no intuito de viabilizar uma chave de leitura geral que pudesse permitir um entendimento dos grandes desvios, a nosso ver, e não "pequenos desvios" como

LÉVY, C. e GROS, F. (Orgs.). Foucault et la philosophie antique. Paris: Kimé, 2003. PRADEAU, J-F. Le sujet ancien d'une éthique moderne. À propos des exercices spirituels anciens dans l'Histoire de la sexualité de Michel Foucault. In. GROS, F. (Org.) Foucault, le courage de la vérité. Paris: PUF, 2002, p.131-154.

${ }^{20}$ CHARTIER, R. Au bord de la falaise: l'histoire entre certitudes et inquiétude. Paris: Albin Michel, 1998. p.194. 
pretende Chartier, presentes em seu percurso filosófico ${ }^{21}$. Sob este prisma, é urgente nos posicionarmos nesta espécie dinâmica de contração e dilatação temática que circula, implicando, assim, em determinadas escolhas. Como ficamos, então?

Desde o instante em que o empreendimento foucaultiano pôs em foco uma série de pesquisas atinentes às descontinuidades, transformações relativas ao entendimento da história, ao tratamento dispensado aos eventos, à ênfase nos processos e nos jogos de transformações específicas, às diferenças que existem e pairam sobre estas múltiplas transformações, cada qual marcada por condições e regras específicas, ligadas a esquemas de dependências que podem ser encontradas e determinadas em suas e por suas práticas; enfim, desde lá, a história passou a ser problematizada como análise descritiva dos processos de transformações e de suas condições não à guisa de um caráter extensivo, quantitativo, porém, intensivo ${ }^{22}$. Com isto, a própria filosofia da história; as periodizações concernentes à ciência história; o tratamento dispensado aos seus documentos; a centralidade dos acontecimentos e suas respectivas valorizações; os atores relacionados a ela, suas ações e pensamentos; a expectativa quanto ao vir-a-ser de um homem histórico, circunscrito a uma temporalidade e existência; para nos valermos de algumas questões, passaram a ter um outro tipo de fundamento e a receber um questionamento inovador.

Atentos a isto, queremos sustentar que há uma intensidade incoativa de questões e conceitos que operam, como gostaríamos de designar, sob a dinâmica de um múltiplo acumulado, desprendendo-se sob a especificidade de uma compreensão de história que faz circular o conjunto de problemas que o pensamento de Foucault pode comportar. Isto significa que há uma espécie de força motriz conceitual necessária à obra que permite o entendimento das distintas etapas de seus trabalhos em campos tão distintos. Mas se pode ser

\footnotetext{
${ }^{21}$ Destacamos alguns pontos: em 1977, Foucault classifica a sua obra numa grade de leitura que centraliza a questão do poder: aspectos "jurídicos e negativos" e suas "técnicas e estratégias" (Cf. Les rapports de pouvoir passent à l'intérieur des corps. Dits et Écrits III, No 197 , 1997, p.228-236). Um ano adiante, 1978, Foucault tenta organizar o seu percurso em "livros de exploração e livros de método" (cf. Entretien avec Michel Foucault. Dits et Écrits $I V, \mathrm{~N}^{\circ}$ 281, 1980, p.42). Na aurora da década de 1980, o filósofo propõe um novo corte retrospectivo, organizado conforme os deslocamentos temáticos que seu percurso de empreendimentos promove: agora se trata de uma "história da subjetividade" (cf. Subjectivité et vérité. Dits et Écrits IV, № 304, 1981, p.213 ss) - diz-nos "não é o poder, mas o sujeito que constitui o tema geral de minhas pesquisas" (cf. Le sujet et le pouvoir. Dits et Écrits IV, $\mathrm{N}^{\circ} 306,1982, \mathrm{p} .223$ ). Avançando-nos anos oitenta adentro, encontramos duas tentativas distintas: em 1983, é a relação sujeito com os jogos de verdade - verdade e veridicção - que vêm a lume por meio de "uma história que não seria aquela do que pode e deve ter de verdadeiro nos conhecimentos; mas uma análise dos "jogos de verdade", dos jogos do verdadeiro e do falso, através dos quais o ser se constitui historicamente como experiência, quer dizer, podendo e devendo ser pensado. Por meio de quais jogos de verdade o homem se permitiu pensar seu ser próprio quando se percebe como louco, quando se olha como doente, quando se reflete como ser vivo, que fala e trabalha, quando se julga e se pune como criminoso?" (Usage des plaisirs et techniques de soi. Dits et Écrits IV, $\mathrm{N}^{\circ} 338,1983$, p.542). Enfim, um ano mais tarde, Foucault tenta nomear a sua "empresa de História crítica do pensamento" (cf. Foucault. Dits et Écrits IV, No 345,1984, p.631).

${ }^{22}$ Cf. Linguistique et sciences sociales. Dits et Écrits I, 1954-1975, No 70, 1969, p.849-874.
} 
assim, afinal de contas, a que veio a história empreendida pelo filósofo francês? Constatar um novo regime de mudanças e transformações? Esclarecer o que pode ser uma "história efetiva"? Prometer algum fundo revolucionário? Destruir falsas evidências, a fim de quê? Qual a força que exerce o pensamento deste "contemporâneo fundamental", na expressão de Lebrun, para a própria contemporaneidade? Aliás, não seria demais se indagássemos: o que permite e alcança o pensamento de Foucault quando é conjugado, e tão somente assim conjugado, com a história?

Segundo a nossa hipótese, a construção de respostas satisfatórias a este núcleo de questões atrela-se ao desenvolvimento de três aspectos nodais que, ao mesmo tempo, preparam terreno para a compreensão do lastro metodológico do qual o pensador se valeu e das implicações práticas coextensivas a este tratamento. São eles: a própria questão da história; o que é a crítica e o que vem a ser problematização. Embora tais perspectivas não se consumam de uma só vez, mas ganham espaço e importância no decorrer de seus mais distintos percursos, sustentamos que trabalham de modo indissociável, compondo um campo decisivo de compreensão dos operadores conceituais e dos desníveis presentes no âmbito geral da obra. Ademais, é por intermédio destes termos que é possível sustentar a presença de uma força coerente que delinearemos mais adiante.

Ora, que a história como questão é um foyer no pensamento de Foucault não se pode negar. Desde que ele tentou mostrar, como não nos deixa esquecer a História da loucura, a marcha dos "grandes rompimentos silenciosos do homem", passando pela tentativa de se "fazer história do passado nos termos presentes", com o intuito de se "pensar diferentemente em vez de legitimar o que já se sabe" ${ }^{23}$, um conjunto de questões começou a emergir, perturbando e inquietando os regimes das evidências e, por conseqüência, antepondo-se às próprias práticas humanas consignadas a determinadas compreensões de história. De maneira muito esquemática e preliminar, a concepção de história que Foucault põe em causa e questiona, nos termos de Revel, "a história concebida como contínua, linear, provida de uma origem e de um telos" 24 ; formula novos instrumentos para pensarmos o acontecimento, sobretudo a partir de certas periferias silenciosas e relatos aparentemente menores, para, assim, lançar luz às transformações que cindem e cortam as práticas humanas; desenvolve um tipo de análise que reformula a relação da história com o seu conteúdo, notadamente, a partir da noção de arquivo, épistémè, dispositivo, relações discursivas e não-discursivas. Outrossim,

\footnotetext{
${ }^{23}$ As indicações estão presentes, respectivamente, nas seguintes obras: Histoire de la folie à l'âge classique, p.654; Vigiar e Punir - História das violências nas prisões, p.32; História da Sexualidade - o uso dos prazeres, p.13.

${ }^{24}$ REVEL, J. Le vocabulaire de Foucault. Paris: Ellipses, 2002, p.42.
} 
põe em xeque as formas pelas quais é possível conhecer aquilo que se conhece, inclusive o próprio conteúdo da história, o que é eleito como conteúdo, pois, se ainda há um determinado tipo de filósofo, ele deve estar próximo daquele que "desempenha qualquer tipo de papel de arqueólogo, que estuda o espaço no qual se desdobra o pensamento, as condições deste pensamento e seu modo de constituição"25.

Que seja assim. Mas o que torna decisivo a presença da história nesta perspectiva? Temos de notar o tratamento específico que o filósofo dispensa à crítica. Menos que defini-la, será preciso indicar as distintas maneiras em que se configura, concretiza-se e exerce uma força relacionada ao eixo das questões práticas, pois, se há um problema a ser desdobrado, é justamente o da relação entre um tipo de trabalho que privilegiou variantes de práticas discursivas e não-discursivas como formação de meios e formas de conteúdo das discursividades. Estas perspectivas poderiam se aproximar, distanciar-se ou mesmo fundir-se? Numa certa etapa de sua obra, Foucault nomeou o conjunto de seu empreendimento de História Crítica do Pensamento ${ }^{26}$. Se indagarmos o próprio sentido de crítica e, concomitantemente, se olharmos com atenção aos movimentos de seu empreendimento, esta concepção se faz presente e marca todos os fios e direções temáticas? Imbricada à história, será preciso demonstrar que a crítica indaga sobre a possibilidade da experiência: como uma experiência humana torna-se possível ao conhecimento? Há um tipo de saber que passa $a$ saber determinado conhecimento, a falar sobre ele a ponto de modificá-lo? Como a tarefa de trabalho de cunho historiador é possível revelar o que se pode saber? Em que medida a história revela o que se pode saber? Em jogo, uma audácia do conhecimento: o que se pode e deve-se conhecer? O que legitimará, e de quais maneiras, este saber-conhecer? Mas, igualmente, pela crítica, um outro tipo de experiência humana pode emergir? Daí, a razão de investigarmos como Foucault associou o saber ao poder, poder-saber, já que a crítica afronta, inevitavelmente, toda forma e relação de verdade, jogos de verdade, consignados à constituição do que podemos saber, fazer e ser. Por quê? Porque a crítica deve permitir um exame das práticas históricas que o saber pode emergir com intuito de indagar como as formas de práticas que possibilitam o "indivíduo ser ao mesmo tempo sujeito e objeto de seu próprio conhecimento" 27 relacionam-se, transformam-se, diluem-se e caracterizam-se por intermédio de determinadas situações discursivas e práticas interpostas entre o que se sabe, o que se pode e o que se é. Saber, poder e ser, numa leitura deleuziana, seriam os eixos

\footnotetext{
${ }^{25}$ FOUCAULT, M. Qu'est-ce qu'un philosophe ? Dits et Écrits I, No 42, 1966, p.553.

${ }^{26}$ Cf. Foucault. Dits et Écrits IV, No 345,1984 , p.631.

${ }^{27}$ FOUCAULT, M. O nascimento da clínica, p.217.
} 
fundamentais de pesquisa de Foucault. Ademais, a crítica também põe em evidência as relações práticas atinentes ao que se pode aceitar ou rejeitar quando se conhece. A crítica será uma "arte da insubordinação voluntária", pois se indaga pelas formas de verdade e, ao mesmo tempo, conduz-nos às evidências dos processos históricos que nos fizeram tomar por verdadeiro, o que resguarda uma trama ampla e complexa de constituição em transformação: razão, história, loucura, poder, saber, sociedade, sexualidade, verdade, realidade, governo, vida, ética, sujeito, enfim, isso só para nos atermos a alguns exemplos.

Ocorre, contudo, que além deste aspecto fundamental da crítica, desde 1978, com Qu'est-ce que la critique? Critique e Aufklärung, Foucault não cessou de indicar a relevância da atualização desta temática kantiana ${ }^{28}$ e de instilar uma interpretação peculiar que fizesse sentido a uma questão que passou a instar a leitura que Foucault fazia de seu próprio percurso para a direção da governamentalidade. Quer dizer, a indagar pelas formas históricas que permitem que os indivíduos cumpram certas funções como sujeitos. Em causa, as relações históricas pelas quais somos sujeitados, portanto, minorados sob complexas relações de forças que constrangem, quer seja numa relação individual ou coletiva, às obediências homogêneas e sistemáticas que exercem o poder de organização das subjetividades humanas e das relações de governabilidades, focadas nos variados modos de emprego de técnicas. Qual o valor que Foucault atribui ao esclarecimento (Aufklärung)? Como isto se dá e relaciona-se com um pensamento que já tinha posto em xeque o próprio sentido de razão universal? Estaria o filósofo francês disposto a assumir princípios de condução de si conforme uma razão universal esclarecida?

A importância deste núcleo de questões não é relevante simplesmente porque se trata de um tema espinhoso e de difícil conexão com as próprias características do pensamento foucaultiano. Para nós, além de o filósofo relacionar Aufklärung com atitude, sublinhará uma interpretação e a sua atualização ao campo de uma crítica permanente ao nosso ser histórico, implicando diretamente na compreensão do que ele designou, mais tardiamente, de ontologia crítica de nós mesmos. Evidenciar isto é de suma importância para nos distanciarmos de um conjunto de interpretações associativas, isto é, que enxergam nesta questão um vínculo identificador ou redutor qualquer, mesmo que em termos gerais. Assim, mesmo que Habermas considere que a flecha no tempo presente do pensamento de Foucault, como tarefa, “não pode ser mais a de fazer sobreviver a Revolução e a Aufklärung enquanto modelos”, mas

\footnotetext{
${ }^{28}$ Também em 1984, surge Qu'est-ce que les Lumières? Cf. Dits et Écrits IV, No 339, 1984, p.562-578. Publicado originalmente como What is Enligthenment? In. RABINOW, P. The Foucault reader. New York: Pantheon Books, 1984.
} 
uma tarefa que "seria preferencialmente a de se interrogar sobre os móveis históricos particulares que triunfam e escondem-se no pensamento universalista desde o fim do século XIX"29, invocará uma associação com a qual não podemos concordar. Diz-nos Habermas:

entretanto, enquanto Foucault não tinha feito até aqui senão que seguir a pista desta vontade de saber nas formações modernas do poder, a fim de denunciá-la, ele a mostra agora sob uma outra luz já que concebe um impulso crítico que importa de ser preservado, e que é necessário de renovar, impulso que prende seu próprio pensamento ao início da modernidade ${ }^{30}$.

Causa-nos estranheza, portanto, o pensador alemão, depois de bem assinalar que "Foucault descobre em Kant o contemporâneo que transforma a filosofia esotérica em crítica do tempo presente, que responde à provocação do instante histórico" ${ }^{31}$, conceber o pensamento de Foucault sob uma força contraditória submersa "nas águas territoriais do

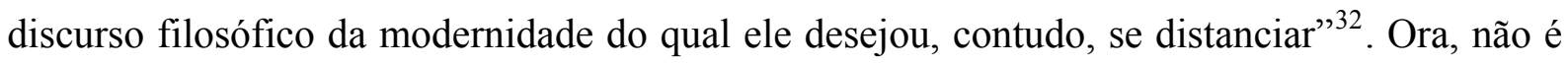
pelo fato de o filósofo indagar pelas condições do saber e, além disto, indagar pelos próprios meios de o saber alcançar a sua crítica, de se impor ou indicar caminhos para esta relação, de fato marcas da modernidade, que Foucault estará fadado aos avatares modernos ${ }^{33}$. Mais fundamental do que isso, é indagarmos pela força e ação da crítica ao tempo presente, sob o signo de um pensamento que é essencialmente anti-reducionista. Tanto é, que o percurso das pesquisas foucaultianas não pode ser constrangido ao eixo saber-poder, como salienta Habermas, mas, como bem sabemos, está para além de um recorte temporal a ser designado por modernidade. Importa, talvez, ressaltar que, para Foucault, a Aufklärung inaugura um novo modo de interrogação que não pretende dissociar os aspectos teóricos essenciais para a compreensão e leitura do presente e da atualidade em detrimento de ações práticas: o que estamos fazendo e podemos fazer conosco mesmo? Seria a questão fundamental.

Tudo isto, todavia, não deixa de ter implicância longitudinal na filosofia de Foucault. Depois de desenvolver pesquisas que levavam em conta uma dimensão de "experiências anônimas" circulantes num "fala-se anônimo", o que nos faz lembrar das forças estruturais na história; de situar o saber sob um conjunto de condições que implicam necessariamente numa

\footnotetext{
${ }^{29}$ HABERMAS, J. Une fleche dans le coeur du temps présent. In: Critique - Michel Foucault du monde entier, No 471-472, 1986, p.789.

${ }^{30}$ Ibidem, p.799.

31 Ibidem, p.795.

${ }^{32}$ Ibidem, p.799.

${ }^{33}$ Habermas considera que o texto de Kant, Was ist Aufklärung "numa certa medida, inaugura o discurso filosófico da modernidade" (cf. opus cit. p.795). Mesmo que Foucault assuma a importância do assunto como "a questão da modernidade" (cf. Qu'est-ce que les Lumières? Dits et Écrits IV, No 351, 1984, p.681), é necessário, no decorrer da pesquisa, entender o modo de emprego que o filósofo faz desta questão e, aliás, explicitar a sua engrenagem com o que podemos, sim, chamar de crítica à modernidade.
} 
determinada forma de saber; de colocar o poder atrelado ao saber numa conjugação infinita e reticular, donde não há espaço ausente de relações de poder; como seria plausível e não contraditório fomentar ações práticas diferentes das ações já estruturadas e permitidas? De que forma, se o poder já está lá, uma experiência é possível, efetivamente, para além do que o poder lhe permite? Por que, afinal, novas formas de pensar e agir poderiam ser atribuídas aos impulsos ocasionais de uma história événementiel ou as constelações particulares de uma situação histórica deliberadamente provocada? Não estaríamos inevitavelmente presos num "dilema teórico", para nos valermos de uma expressão de Honneth? Pior, não estaria Foucault apelando para um tipo de esclarecimento que nos levasse a uma espécie de "pretensão de propor soluções gerais e definitivas aos problemas filosóficos de nosso tempo", conforme a crítica de Hadot? ${ }^{34}$ São aspectos que, se por um lado não podem ser ignorados, também não devem ser empalmados sem uma reflexão maior a qual, segundo o nosso julgamento, está subsumida ao entendimento da extensão dos problemas atinentes à peculiaridade e forma filosóficas de Foucault.

Tanto é assim, que o ponto alusivo à crítica não pode ser levado em consideração sem o cultivo de um termo que marca, em especial, os anos finais da pesquisa foucaultiana. Referimo-nos à questão da problematização. Em nosso entendimento, a idiossincrasia dos trabalhos de cunho históricos realizados por Foucault está, par e passo, relacionada com o desenvolvimento da crítica e da acepção de problematização. Trata-se de colocar em evidência que não há um objeto preexistente, nem dado; muito menos um objeto que não existe. Contudo a problematização ressalta "o conjunto de práticas discursivas ou nãodiscursivas que fazem entrar qualquer coisa no jogo do verdadeiro e do falso e o constitui como objeto para o pensamento (quer seja sob a forma da reflexão moral, do conhecimento científico, da análise política etc)"35. Quer dizer que, se há uma história do pensamento em Michel Foucault, ela se apresenta sob o interesse de colocar como problema as várias formas de constituição de objeto, ou seja, ela os problematiza com o intuito de indagar a relação existente com a verdade que permite a sua representação e maneira de ser numa época dada.

Em outra dimensão, a problematização permite entendermos a engrenagem radical do empreendimento nomeado pelo filósofo francês de história crítica do pensamento. Distanciando-se da história das idéias e das mentalidades, Foucault reforça a sua originalidade por estar consciente de que "várias respostas podem ser dadas" a um objeto qualquer. Assim, mais uma vez, questiona-se a verdade como elemento fundamental da constituição dos

\footnotetext{
${ }^{34}$ HADOT, P. Exercices spirituels et philosophique antique. Paris: Albin Michel, 1993, p.311.

${ }^{35}$ FOUCAULT, M. Le souci de la vérité. Dits et Écrits IV, No 350, 1984, p.670.
} 
elementos identificadores da história ocidental. Por ora, podemos destacar dois aspectos: a constante antropológica e a variação cronológica. Problematizar pressupõe modos, portanto não se trata de uma forma; mas de uma amplificação e disseminação de análises, numa singularidade histórica, que revolvem uma série de indagações necessárias que permitiram, ao mesmo tempo, a simultaneidade da emersão de um objeto e das expressões necessárias que tornaram condições possíveis para se pensar este objeto. “Ora, o que é preciso compreender é o que os torna simultaneamente possíveis; é o ponto onde se enraízam suas simultaneidades; é o solo que pode nutrir uns e outros, em sua diversidade e a despeito, às vezes, de suas contradições" ${ }^{36}$. Não sem sentido, a problematização vincula-se a uma análise crítica e viceversa.

Ora, segundo a nossa hipótese, o desenvolvimento da concepção de problematização se desdobrará em três frentes de longo alcance. Sem intentarmos planificar os questionamentos que rodeiam o pensamento de Foucault, mas, ao contrário, levá-los às últimas conseqüências, cremos que é possível indicarmos um caminho de superação das questões que se pautam pela incoerência e impasses; que indagam pelas soluções advindas do pensamento de Foucault para o nosso tempo; ou, ainda, que intentam limitá-lo por uma identidade irrevogável. Contudo a problematização aprofunda o registro da descontinuidade, em primeiro lugar, pois não se preocupa com a moldura limitadora: os quadros históricos de Foucault não têm molduras. Segundo, enfatiza a heterogeneidade no lugar do homogêneo, quer seja no âmbito das perguntas quer seja no veio das respostas. Enfim, a problematização se opõe a uma pesquisa metódica de solução, pois a tarefa da filosofia e do pensamento não seria a de resolver, mas de problematizar, o que significa repensar e recolocar problemas e não meras perguntas e respostas. A implicância desta dinâmica, história, crítica e problematização, a nosso ver, é o que nos autoriza a buscarmos uma chave de entendimento para os problemas que arqueologia e genealogia eclodem. Ao mesmo tempo, permite-nos vislumbrar o percurso do pensamento de Foucault por uma questão que não deixa de ser onicirculante como problema e crítica: a sináptica sujeito-subjetividade. Senão vejamos.

Em nosso juízo, se há um aspecto a se intensificar no pensamento de Foucault, iremos encontrá-lo no campo temático do sujeito. Ora, se a descontinuidade é chave central e imprescindível para o entendimento da história, sendo a sua marca mais idiossincrática, não podemos ignorar que ela se opõe à perspectiva contínua de história que, por sua vez, nos termos próprios do filósofo francês,

\footnotetext{
${ }^{36}$ FOUCAULT, M. Polémique, politique et problématisations. Dits et Écris IV, $\mathrm{N}^{\circ} 342,1984$, p.597-598.
} 
é o correlato indispensável à função fundadora do sujeito: a garantia de que tudo que the escapou poderá ser devolvido; a certeza de que o tempo nada dispersará sem reconstituílo em uma unidade recomposta; a promessa de que o sujeito poderá, um dia - sob a forma da consciência histórica -, se apropiar, novamente, de todas essas coisas mantidas à distância pela diferença, restaurar seu domínio sobre elas e encontrar o que se pode chamar sua morada ${ }^{37}$.

Não é à toa, portanto, que, desde a História da Loucura até o momento final de sua obra, Foucault tenha trabalhado para elucidar os processos de mutações históricas que operam na constituição de determinados tipos de sujeitos, contudo, para "desfazer as últimas sujeições antropológicas", evidentemente com o intuito de mostrar como essas sujeições puderam se formar $^{38}$. Nada mais coerente, então, do que pensarmos um longo processo de transformações históricas, descontínuas, é importante frisar, mas que perseguem as análises das condições nas quais é possível que um tipo de indivíduo ocupe certas funções como sujeito. História e subjetividade cortam a obra de Foucault; são temas onicirculantes que se ocupam em esclarecer e compreender as maneiras pelas quais nos tornamos contemporâneos. Para que, afinal? Se tomarmos a indicação crítica e problemática da obra, será preciso evidenciar que tipo de sujeito Foucault nega, de um lado; e que tipo de sujeito o filósofo afirma. A nosso ver, esta é a relação possível entre arqueologia e genealogia.

Em 1982, em um curso denominado A hermenêutica do sujeito, encontramos uma indicação precisa e esclarecedora por parte do filósofo, que julgamos vital para o que sustentamos. Diz-nos Foucault:

o que venho pretendendo colocar há algum tempo, que é, fundamentalmente, o seguinte: como se estabelece, se fixa e se define a relação entre o dizer-verdadeiro (a veridicção) e a prática do sujeito? Ou ainda de modo mais geral: como o dizer-verdadeiro e o governar (a si e aos outros) se vinculam e se articulam um ao outro? Este é o problema que tentei abordar sob numerosos aspectos e formas - seja a propósito da loucura e da doença mental, seja a propósito das prisões e da delinqüência, etc - e que agora, a partir da questão a que me propus sobre a sexualidade, gostaria de formular diferentemente, de um modo ao mesmo tempo mais estritamente definido e ligeiramente deslocado em relação ao domínio que escolhi, e [convocando períodos] historicamente mais arcaicos e mais antigos $^{39}$.

Três questões cruciais desprendem-se a partir deste contexto. Primeiro, o Foucault leitor de Foucault apresenta uma nova frente de compreensão da obra, colocando-a sob um registro importante: o da relação sujeito e verdade; por conseguinte passa a focalizar a múltipla démarche de suas pesquisas nesta direção. Segundo, abre um espaço para indagarmos o

\footnotetext{
${ }^{37}$ FOUCAULT, M. A arqueologia do saber, p.14-15.

${ }^{38}$ Cf. opus cit. p. 17.

${ }^{39}$ FOUCAULT, M. A hermenêtica do sujeito, p.281.
} 
estatuto da relação entre seus métodos: arqueologia e genealogia; pois, se há um problema fundamental, como entender as diferenças de acentos e problemáticas encontradas entre elas? Terceiro, ressalta a descontinuidade no recorte histórico: o deslocamento do Período Clássico, presente desde o início em suas pesquisas, para os "arcaicos e mais antigos".

Mais uma vez, será preciso invocar crítica e problematização para a compreensão do método de Foucault ${ }^{40}$, pois, como bem assinalou Lebrun, "é necessário remontar ao método de Foucault - que raramente despertou interesse" ${ }^{41}$. Mas qual seria o interesse, afinal? Como nos fez ver Revel, se tomamos a subjetividade como tensão central, é preciso notar que arqueologia e genealogia põem em operação duas situações as quais, embora diferentes, oferecem motivos às mudanças de passagens, campo de interesse, intensificações temáticas e de instrumentos conceituais. De um lado, a arqueologia faz emergir os processos históricos que ativaram os mecanismos de sujeição constituidores dos sujeitos; de outro, a genealogia quer ativar os mecanismos de dessujeição dos saberes históricos e de suas verdades constituidoras de sujeitos. Assim, "a genealogia se constitui progressivamente em Foucault e do interior mesmo da arqueologia" ${ }^{\text {42 }}$. Mas também poderíamos pensar sob um registro que privilegia a verdade, como elabora Gros, ao indicar que a arqueologia presume os cálculos dos efeitos da verdade, enquanto a genealogia, os atos da verdade ${ }^{43}$. É evidente, sob este ângulo, que podemos pensar nos múltiplos planos arqueogenealógicos que são problematizados em torno da temática do sujeito, o que pressupõe, é claro, as suas distintas relações com a verdade, já que "a crítica toma assim sua forma de uma arqueogenealogia do sujeito visando liberá-lo das obrigações, das estruturas, falsamente necessárias e essenciais, que pesam sobre sua constituição"44. Mas como isto é possível?

Sustentamos que a condução empregada na análise da arqueologia e da genealogia é o que permite a via de uma coerência no decorrer do prolongamento da obra sob o viés de

\footnotetext{
${ }^{40}$ Embora saibamos que a noção de método nos remete, é inegável dizê-lo, à tarefa cartesiana de investigação, para bem conduzir a própria razão e procurar a verdade nas ciências, podemos dizer que Foucault, ao fazer da arqueologia e genealogia um método de investigação histórica e de problematização filosófica, não deixa de ser, desde a História da loucura, um antípoda de Descartes, no sentido que vai trabalhar para desnaturalizar o alcance da razão e de sua eficácia enquanto identidade de um "homem racional" ou de um sujeito fundador. Foucault quer destruir as unidades de representação. Eivado pela problemática dos enunciados e das práticas, o método inaugura uma ordem de rupturas e singularidades em que a história não mais nos remete a um cogito, nem a um sujeito transcendental ou a um eu capaz de pronunciá-la pela primeira vez. Comentadores como Adorno, Revel, Veyne e Deleuze caminham nesse mesmo sentido de apontar arqueologia e genealogia como métodos.

${ }^{41}$ LEBRUN, G. Passeios ao léu. Ensaios, p.78.

${ }^{42}$ REVEL, J. Expériences de la pensée - Michel Foucault, p.75-76

${ }^{43}$ GROS, F. Michel Foucault, une philosophie de la vérité. In. Michel Foucault. Philosophie, antologie. Paris, Gallimard, 2004, p.11-25.

${ }^{44}$ ADORNO, F. P. La tâche de l'intellectuel: le modèle socratique. In. GROS, F. (Org). Foucault, le courage de la vérité. Paris: PUF, 2002, p.49.
} 
novos caminhos enriquecedores da subjetividade. Sendo assim, nos distanciaremos da postura de Dreyfus e Rabinow ao sustentar o "fracasso da arqueologia"45. Por acentuarem demasiadamente o aspecto do discurso na arqueologia, enganam-se ao tomar o enunciado somente no plano discursivo e negligenciar seus aspectos não-discursivos. Isto ocorre por considerarem a arqueologia dentro de um ciclo que se fecharia nas obras de Foucault da década de 1960. Ao proporem que, desde Vigiar e Punir, a etapa genealógica é inaugurada, praticando uma "inversão da prioridade da teoria para a da prática" ${ }^{46}$, acentuam um caráter que não é verdadeiro por inteiro, pois nela também encontramos uma problematização das práticas fundadas num certo saber, quer dizer, das condições que um tipo de saber encontra para emergir. Também, ao que nos parece, não reforçam as noções de descontinuidade e continuidade, jogo fundamental na compreensão do pensamento foucaultiano. Além do mais, seria muito temeroso situar as pesquisas voltadas para as práticas de reclusão sob o viés do poder, sem considerar as relações existentes entre enunciados discursivos e não-discursivos, que são, notadamente, prático-concretos.

Se há "um abandono de certo número de postulados" na obra de Foucault, como assinala Deleuze, é porque "marcam um novo progresso decisivo, um novo tom, uma nova política"47 e não uma incoerência ou negação conceitual. Assim, fica difícil conceder total razão a Ewald ao sustentar "a inauguração de uma perspectiva nova" também a partir de Vigiar e Punir, pelo fato de ocorrer um afastamento de Foucault do tratamento dos discursos e dos arquivos, tendo em foco "o problema do poder e do corpo (dos corpos)" traço político da obra é reforçado pelo fôlego das análises focalizadas nas técnicas de poder. Mas a genealogia não se centraliza tão somente na questão do corpo imerso nas tramas políticas, melhor, na anatomia política da sociedade; ela focaliza também o próprio valor que é possível de se atribuir a tal análise, o que, portanto, coloca, mais uma vez, a verdade em cena.

É necessário atentar para este aspecto conflitante e crucial, interposto entre os conceitos-chave da arqueologia e genealogia. Os pontos que devem ser sublinhados, tal como concebemos, ultrapassam uma simples tomada de posição ou diagnóstico no que concerne à possibilidade ou não de relacionarmos o conjunto global de temáticas da arqueologia com o da genealogia. Mais do que isto, trataremos de mostrar que há uma transversalidade possível que, apesar de não pretender resolver os conflitos de temas, preferem amplificar as constantes

\footnotetext{
${ }^{45}$ DREYFUS, H e RABINOW, P. Michel Foucault: uma trajetória filosófica, p.89ss.

${ }^{46}$ Ibidem. p. 114.

${ }^{47}$ DELEUZE, G. Écrivain non: un nouveau cartographe. In Critique, n.343, décembre 1975, p.1208.

${ }^{48}$ EWALD, F. Anatomie et corps politiques. In Critique, n.343, décembre 1975, p.1229.
} 
problematizações que, sob a forma das fissuras alongadas, articulam questões do eixo do saber, poder e da subjetividade. Tanto é, que a análise da noção de dispositivo nos auxiliará nesta empreitada e no entendimento da descontinuidade.

Isto é vital para nos antepormos a um tipo de interpretação que defende a retomada do sujeito, como se fosse "a volta do recalcado", na consideração de Dosse. Ademais, o que estaria em jogo não seria somente esta volta, mas igualmente um "retorno do sujeito", pois, na diferente "abordagem historiadora", Foucault, ao desenvolver o "governo de si" desde o movimento final da História da Sexualidade, como insiste nosso comentador, "acentua, portanto, esse movimento do retorno do sujeito" ${ }^{, 49}$. Posta desta maneira, a arqueologia tornase impossibilitada de aspirar a qualquer pertencimento temático à genealogia ${ }^{50}$. Pior, galvanizaria um estancamento interpretativo que tem de se ater ou à arqueologia ou à genealogia. Mas é bom notar que o aspecto de coerência é mencionado: a governabilidade. Afinal, este veio de problematização não deixa de ser fulcral na subjetividade: se a história pode revelar os processos de sujeitamento do homem no Ocidente, não são as análises das práticas de governabilidade de si e dos outros um foco relevante? Não emergiriam do problema do fechamento ou aprisionamento dos indivíduos em asilos, hospitais, quartéis, escolas, prisões; da administração de corpos (indivíduos) e populações (coletividades); do controle exercido sobre a subjetividade por intermédio de jogos de verdade e veridicção, uma história a realçar os aspectos de governabilidade forjadores de práticas subjetivas por intermédio do uso e aplicação de certas forças? E isto não nos levaria a indagar por respostas contundentes: qual intervenção possível que o sujeito pode a si mesmo? E em relação aos outros? Como confrontar a relação de forças que se estabelecem entre governo de si e governo dos outros?

São as análises históricas efetuadas a partir do curso Il faut défendre la société, de 1975-76; é da radicalização política em Sécurité, territoire, population, de 1977-78 até o momento final da formalização dos dois últimos volumes da História da Sexualidade, 1984, que as questões atinentes aos processos problematizadores em torno da história e subjetividade são levadas às últimas conseqüências. Conduzindo a obra desta forma, nos

\footnotetext{
${ }^{49}$ DOSSE, F. História do Estruturalismo, v. 2, p.361 e também A história à prova do tempo. Da história em migalhas ao resgate do sentido, p.234.

50 Do mesmo modo, não podemos concordar com a perspectiva de ver na etapa genealógica uma instrumentalização temática que compensaria uma certa frustração de percurso no que diz respeito à filosofia de Foucault: "Esse desvio pela Grécia e por Roma remete, por conseguinte, em grande parte, ao não-dito do indivíduo Foucault, à sua busca desesperada e urgente de uma ética, de uma ascese espiritual compensatória de um desprendimento próximo de seu corpo, de uma libertação da culpabilidade mortífera que o habita, e de uma reconciliação final consigo mesmo. Decididamente, o sujeito está de volta". DOSSE, F. História do Estruturalismo, v.2, p.389.
} 
distanciamos das análises que, passando por Ferry e Renaut, primam por conceber uma duplicidade de registro no âmbito do pensamento de Foucault, sub-repticiamente produzindo "sérios problemas de coerência filosófica". Tal duplicidade de registro, leia-se da arqueologia à genealogia, iria se assentar na interpretação de que o filósofo francês, operador, dentre outros, da "destruição da subjetividade pela filosofia francesa dos dois últimos decênios" por intermédio de suas "obras fundamentais (História da loucura, As palavras e as coisas, Arqueologia do saber etc), que deram origem a uma espécie de 'vulgata' foucaultiana centrada notadamente sobre o tema da "morte do homem", teria tratado, em seus "últimos trabalhos publicados (História da sexualidade)", de repor, "em termos não exclusivamente críticos", o sujeito. Donde estaria Foucault preocupado, em última hora, em reconstruir uma história do sujeito ${ }^{51}$.

Mas como o próprio Michel Foucault enfatizava, deixemos os "espíritos simplistas". Há uma mobilidade perpétua na obra imbricada com a atividade de pôr em suspeição e à prova os limites do que se pode conhecer - até onde se pode saber - dos processos históricos múltiplos e aparentemente desconexos uns dos outros, que funcionam como campo gravitacional para a questão da subjetividade ocidental e atual. Neste contexto, será exigido de nós, como nos permitiu enxergar Deleuze, uma análise das “variáveis e variações” presentes no trabalho de Foucault, o que dá lugar para o aspecto do múltiplo acumulado. Assim, é imprescindível reconhecer "as variáveis do saber (por exemplo, objetos e sujeitos como variáveis imanentes do enunciado) e a variação das relações de formas; as singularidades variáveis do poder e as variações das relações de forças; as subjetividades variáveis, e a variação da dobra ou da subjetividade" ${ }^{, 52}$, atuando de modo transversal sob os domínios de uma história crítica do pensamento.

Com esta perspectiva, trazemos para o centro da discussão as distintas modalidades pelas quais o desenvolvimento tanto conceitual quanto operacional em torno da história e da subjetividade foram explorados e problematizados no travail en cours do filósofo francês. Em um nível, o sujeito que fala, trabalha ou vive sob a constituição de um discurso científico das "ciências"; um sujeito que se torna, pela operação conjunta do saber e poder, louco, doente, delinqüente, anormal; um sujeito que, atrelado a uma coletividade, passa a ter mensuradas as suas possibilidades instrumentais de vida ou morte - biopoder/biopolítica; um sujeito incitado aos exercícios e práticas de confissão nos interstícios de uma governabilidade, ou seja, a

\footnotetext{
${ }^{51}$ FERRY, L. e RENAUT, A. Pensamento 68: ensaio sobre o anti-humanismo contemporâneo, p.97-98 e 135136.

${ }^{52}$ DELEUZE, G. Foucault, p.123-124.
} 
assumir uma verdade; enfim, a constituição de um sujeito que se torna objeto dele mesmo como prática, como prática e governo de si. Incoerências? Sobreposições? Nivelamento das erosões temáticas? Ou intensificação de problemas? A história segue a trama de duas dinâmicas: a do fundo invisível e a do visível. Ter de demonstrar o desenvolvimento deste jogo foi, a nosso ver, um desafio de ensambladura para Foucault. Pois, outrossim, em cena também se encontra a trama dispersa ao redor do que a história chancela por verdadeiro ou falso. A história como "jogo de verdade" volta-se para a relação dos sujeitos consigo mesmos e com outros.

É desta forma que a subjetividade pode ser problematizada no transcurso da obra e não apenas como temática de revolução ou de mudança de rumo desde a História da sexualidade. Aliás, já a partir de seu segundo volume, o uso dos prazeres, Foucault

extrairá a conclusão de todos os livros precedentes quando ele mostrará que a verdade se dá ao saber apenas através de "problematizações", e que as problematizações se fazem apenas a partir de "práticas", práticas de ver e práticas de dizer. Essas práticas, o processo e o procedimento, constituem os procedimentos do verdadeiro, "uma história da verdade" ${ }^{, 3}$.

Notemos bem que, dessa maneira, a genealogia não prescindiu das questões centrais da arqueologia, ao contrário, serviu de desdobramento para elas. Então, sob o eixo das pesquisas foucaultianas, saber, poder e subjetividade são irredutíveis, entretanto, com implicações diversas que, apesar disto, não cessarão de ser históricas. Assim, não seria extravagante demais afirmarmos que história e subjetividade se entrecruzam, no domínio filosófico de Foucault, para nos levar à persistente indagação tríplice: “Que posso eu? Que sei eu? Que sou eu?" 54 .

A dificuldade, contudo, seria a de tentarmos entender se a concepção ao redor do sujeito é forjada por trabalho específico na história ou se, inversamente, uma determinada concepção de sujeito eclodiu e urdiu a trama histórica à Foucault. Com o intuito de levar esta indagação adiante, será preciso mostrar que a multiplicidade temática alcançada no empreendimento histórico se volta para um trabalho de prospecção que aprofunda o tema

\footnotetext{
${ }^{53}$ Ibidem. p.71. Na mesma direção, está o pensamento de Veyne, para quem "a Histoire de la sexualité não inovou". Aliás, para este comentador "a história-genealogia à Foucault preenche, pois, completamente o programa da história tradicional; não deixa de lado a sociedade, a economia etc, mas estrutura essa matéria de outra maneira: não os séculos, os povos nem as civilizações, mas as práticas; as tramas que ela narra são a história das práticas e que os homens enxergaram verdades e as lutas em torno dessas verdades" (Cf Como se escreve a história e Foucault revoluciona a história, p.279).

${ }^{54}$ Ibidem. p. 123 .
} 
subjetividade à medida que se coloca sob o eixo das práticas, o que equivale pensar na formação dos objetos e de seus possíveis conhecimentos. Pois, na indicação de Veyne,

longe de nos convidar a julgar as coisas a partir das palavras, Foucault mostra, pelo contrário, que elas nos enganam, que nos fazem acreditar na existência de coisas, de objetos naturais, governos ou Estados, enquanto essas coisas não passam de correlatos das práticas correspondentes, pois a semântica é a encarnação da ilusão idealista ${ }^{55}$.

No mesmo sentido, portanto, não podemos falar de "um" poder, saber, sujeito, enfim, ética, depois de Foucault. Se há um aspecto crítico a ser levado em consideração, neste contexto, é o do nominalismo foucaultiano, perspectiva, aliás, que o filósofo assume desde o lançamento da fórmula: “a loucura não existe", o que não significa que ela não fosse nada ${ }^{56}$. Em foco, está a relação entre sujeito e verdade e uma postura metodológica que realça um "ceticismo sistemático em consideração de todos os universais antropológicos" ${ }^{\text {"57 }}$. Então, compreender ou pensar qualquer objeto é fazê-lo pelo viés das práticas específicas, "cujas determinações devem ser expostas à luz, já que a consciência não as concebe", e o estatuto filosófíco do pensamento não poderá mais se dar pelas questões acerca da unidade do objeto. "Ter dado esse passo decisivo", afirma ainda Veyne, "na negação do objeto natural, confere à obra de Foucault sua estatura filosófica" $" 58$.

História e subjetividade estão imersas num processo de maturação lenta condicionada às linhas móveis de pesquisas que põem em marcha, diz-nos Gros, "um quadro de investigações sobre o "destino do sujeito verdadeiro no Ocidente",59, como ele se fixou, desde um longo tempo, procurando a sua verdade íntima pelo constante sujeitamento a um Outro. Os esforços de Foucault, nesta direção, seriam o de mostrar a emergência de sujeitos históricos que são talhados por práticas sociais da divisão (partage), das relações de força e poder (les pouvoirs), mas também de um sujeito que pode voltar-se para si, num processo de subjetividade, apesar de sua irredutível finitude (practique de soi même). Se há uma descontinuidade neste aspecto, ela se desenvolve na seguinte dimensão: para frações históricas e práticas diferentes, resguardam-se destinos diferentes. Mas o destino do sujeito ocidental já estaria selado?

Uma das marcas mais relevantes nos processos de subjetividade estudados por Foucault é o da direção da consciência, a qual se transforma em alma; esta, por sua vez,

\footnotetext{
${ }^{55}$ VEYNE, P. Como se escreve a história e Foucault revoluciona a história, p. 279.

${ }^{56}$ Cf. Sécurité, territoire, population, p. 122.

${ }^{57}$ Cf. Foucault. Dits et Écrits IV, No 345, 1984, p.634.

${ }^{58}$ Opus cit. p.254 e 265.

${ }^{59}$ GROS, F. Situation du cours. In. L'herméneutique du sujet, p.492.
} 
transforma-se em efeito e instrumento de uma anatomia política. A história dos conjuntos de práticas que serviram de suporte para o sujeito se constituir não se fecha, pois trata-se de "uma sujeição que nunca terminou de se completar" ${ }^{60}$. Então, os processos estão abertos, logo, passíveis de serem modificados. Como de fato isto é possível? Como um sujeito imerso num campo de verdade, poder e governamentalidade poderá ser pensado à guisa de uma constituição própria? Estaríamos vinculados, ainda, às exigências de um esclarecimento? Não há uma pretensão narcisista que se impõe à obra de Foucault: é preciso conhecer tudo isto para fazer operar uma crítica, e daí? Há um senso prático, plausível, nesta história crítica do pensamento? Por onde ele passa? Por uma tomada de consciência? Por uma ação destemperada? São indagações que se impõem e não podem ser ignoradas.

Desta maneira, será preciso mostrar o movimento existente na verticalização das transformações que o filósofo anuncia para evidenciarmos o processo de uma ontologia crítica de nós mesmos. Se a descontinuidade não é um vazio, um intervalo que se coloca na história, mas um jogo de transformações específicas, como resistir aos processos específicos de sujeitamento? Isto toca os movimentos de recusa e afronta que pretendem inaugurar uma política de dessujeição, donde serão testadas as atitudes-limite e atitudes-experimentais que a história permite ao amplo e variável campo de subjetividades.

De nossa parte, contamos chegar a um nível de investigação que mostre, tomando o percurso da obra, como o sujeito se arma em torno da condução problematizadora advinda das práticas historiadas. Se há uma coerência na obra de Foucault, ela é plasmada pelo fato de o filósofo ter mostrado historicamente que de um sujeito da ação, presente na Antiguidade greco-romana, outro conjunto de práticas fizeram uma operação de substituição a partir da modernidade ocidental, para um tipo diverso de sujeito, não, contudo, sem absorver, modificar, suprimir essas mesmas práticas, incitando a sua longa e lenta marcha a uma espera que não cansa de repor as suas próprias transformações.

\footnotetext{
${ }^{60}$ Ibid, p.146.
} 
Articulamos o presente trabalho em três capítulos. No primeiro, denominado $A$ história como espetáculo do mundo, analisaremos a posição e o desenvolvimento da história em torno do distanciamento que Foucault imprime às formas contínuas, universalistas e teleológicas desta ciência humana, como também o seu rompimento com a história das mentalidades e das idéias. Em foco, a descontinuidade e a história como diagnóstico. Levaremos em consideração a análise da noção de dispositivo, fundamental para entendermos as transformações ocorridas no percurso foucaultiano. No mesmo sentido, caberá a nós mostrar como a história se relaciona com duas outras questões cruciais: a crítica e a problematização; essenciais para a compreensão do desenvolvimento conceitual relacionado à história e subjetividade.

Esta etapa será uma espécie de esteio para as análises atinentes ao método empregado por Foucault. Designado Para uma arqueogenealogia: o método de Foucault, o segundo capítulo mostrará que arqueologia e genealogia operam num nível de coerência e verticalização da temática sustentada por nós. De um lado, um conjunto de noções, tais como enunciado, arquivo, a priori histórico, acontecimento e atualidade, será trabalhado a fim de aprofundarmos os problemas e efeitos que a obra intenta alcançar. Mas este alcance é dependente da etapa genealógica e a ela se alia. $\mathrm{Na}$ genealogia, encontramos o questionamento radical da verdade e dos valores advindos da interpretação histórica. Em causa, estará a própria forma que objeto e sujeito são postos em questão pela história. Jogos de verdade, corpos e história efetiva representam pontos centrais que abarcam a relação existente entre arqueologia e genealogia.

A especificidade e originalidade metodológica trabalham em função de desenvolver e apresentar a história dos processos de subjetividades. Assim, o terceiro capítulo, nomeado As relações de forças nos processos históricos de constituição de subjetividades, destacará desde a presença do campo de situações estratégicas para o entendimento das subjetividades, sempre tendo por eixo a discussão com o posicionamento das relações de forças nas distintas maneiras de serem efetivadas em seus usos e aplicações específicos, até chegarmos ao movimento de uma força produtiva de um sujeito de ação, de uma produção de si como acontecimento de dessujeição. Em questão, estão as variantes históricas que exerceram papel crucial na relação constituidora dos indivíduos em determinados tipos de sujeitos, que se relacionam sob um jogo constante de forças. Para nós, esta dinâmica própria da subjetividade inaugurou, a seu modo, formas de governabilidades. Por sua vez, estas formas reforçaram dimensões específicas de subjetividades. Então, temos de passar pelos domínios e estratégias 
voltados para a individualidade e a coletividade como formas de se alavancar certas práticas de subjetividade. Mas a história, ao revelar este complexo processo, está fadada às suas forças e pressões ou pode caminhar no sentido de uma libertação dos domínios? Pergunta que se refere a uma dimensão crítica em sua forma de finalização em atitudes-limite e atitudesexperimentais como tensão e força para a escultura de outras subjetividades e práticas de si, melhor, de governo de si. 


\section{A HISTÓRIA COMO ESPETÁCULO DO MUNDO}

A idéia é de que cada um de nós vive uma série de fatos, $e$ esta série de fatos pode ou não ser paralela a outras.

Por que aceitar esta idéia? É uma idéia possível; ela nos daria um mundo mais vasto, um mundo mais estranho que o atual. A idéia de que não há um tempo.

A idéia de vários tempos.

Jorge Luis Borges Borges, Oral - O tempo.

\subsection{Multiplicidades: figuras históricas em espaços de dispersão}

Colocar em causa história e subjetividade no pensamento de Foucault demanda atentarmos para a relevância da inexorável trama, cujo processo assume transformações em que as cenas vão se modificando, quadro a quadro, em favor de uma abordagem que redobra suas ações como focos de problemas que se aprofundam. Por repetidas vezes, estes quadros são esmiuçados, transformados em cacos, pontuados, meticulosamente escolhidos, a fim de evidenciar a força dos movimentos que comporão as cenas da tragédia dos homens ocidentais, isto é, "a maneira que os homens do Ocidente viram as coisas sem jamais colocar a questão se era verdadeiro ou não, a maneira que eles montaram, por eles mesmos, pelo jogo de seus olhares, o espetáculo do mundo"1. Quando percorremos a obra de Foucault, mais do que em qualquer outra parte, salta aos olhos o seu esforço no sentido de destacar a disposição destas cenas, o ritmo sincopado nelas presente, o tom que vão materializando, o modo como se tornam vivas ao olhar, assumindo sentidos, ao passo que o espetáculo do mundo se firma no seu modo de fazer história. Nesta medida, trata-se mais de saber como se produziram, como se constituíram determinadas cenas cujas especificidades tornaram possível a experiência indelével e intransferível do que somos.

\footnotetext{
${ }^{1}$ FOUCAULT, M. La scène de la philosophie. Dits et Écrits III, N 234, 1978, p. 571.
} 
Quanto a este ponto, é forçoso saber que não podemos olhar para cenas diferentes da mesma maneira. Isto significa pensar, e até mesmo o justificaria, as mutações provocadas ao longo do seu fazer história, pois o que não se deixou de levar em consideração foram as distintas demandas em face da tarefa de evidenciar que, nas cenas de loucura, doença, prisão, sexualidade, não atuava um sujeito original, mas que tais cenas deixavam pistas de que ele possuía um tipo de gênese, um tipo de formação, uma história tão diferente do que se havia imaginado quanto se havia dito ${ }^{2}$. Podemos admitir, assim, um jogo de reformulações operadas por Foucault, cujas regras de análise, eixo de questões, objetivos e conclusões se confundem com os espaços e os tempos abarcados por seu pensamento. O foco principal de nossas preocupações neste capítulo será o de demonstrar como esta dinâmica afeta, modifica e aprofunda a relação entre o seu modo de fazer história e as preocupações concernentes ao que sustentamos como história da subjetividade, o mesmo que dizer dos processos de subjetividades que funcionaram como solo de fecundidade de determinadas experiências que não podem ser separadas de nossa constituição: o cenário impôs o ritmo da cena, da ação e do papel.

Entretanto, apesar das incontáveis torções de fundo teórico presentes na obra, de afirmações outrora sustentadas se transformarem em negações, do não compromisso em desenvolver, por vezes, o que se promete, das cisões elaboradas ao longo de eixos temáticos, um escopo fundamental insiste em revitalizar, ao que pensamos, de diferentes maneiras, os modos de se fazer história em Foucault. A dificuldade crucial, é importante destacar, colocase na encruzilhada das modificações que são austeramente assumidas e das afirmações que tentam alimentar uma espécie de força motriz da obra. Segundo a nossa interpretação, a questão motriz é a subjetividade ocidental; as modificações são frutos de um trabalho de prospecção em torno deste incansável ponto historicizado, quer dizer, elas dizem respeito a um processo inquietante, inacabado, constantemente revisado que não pretende estar no mesmo nível da segurança sistemática.

Apesar disto tudo, se levarmos em consideração as distintas fases da empresa foucaultiana, a rigor, seria possível pôr em relevo o caráter eminentemente coerente de uma problemática a ser acentuada, mesmo por diversos desdobramentos? Em 1961, com a História da loucura, Foucault inaugura a história das "experiências fundamentais pelas quais uma cultura expõe os valores que lhe são próprios"3. Advogando em favor de uma análise "não no

\footnotetext{
2 "O sujeito tem uma gênese, o sujeito tem uma formação, o sujeito tem uma história; o sujeito não é original". Cf. FOUCAULT, M. La scène de la philosophie. Dits et Écrits III, Nº 234, 1978, p. 590.

${ }^{3}$ FOUCAULT, M. Histoire de la folie à l'âge classique, p. 228
} 
nível de uma crônica de descobertas, ou de uma história das idéias, porém seguindo o encadeamento de estruturas fundamentais da experiência" ${ }^{4}$, vislumbramos as transformações ocorridas no homem em relação à sua verdade. "Do homem ao homem verdadeiro, o caminho passa pelo homem louco", , diz-nos Foucault, com intuito de ressaltar as distintas formas pelas quais o tratamento dispensado à loucura acompanha a fundamentação da verdade no homem moderno. Ora, as percepções da loucura que vão se modificando também alteram a relação do homem com a verdade até chegar no ponto em que, por não ser mais o louco considerado insano, mas alienado, aquele que, sendo o que é, carrega um outro:

o homem não é mais considerado numa sorte de retirada absoluta em relação à verdade; ele é sua verdade e o contrário de sua verdade; é ele mesmo e outra coisa que ele mesmo; é tomado na objetividade do verdadeiro, mas é verdadeira subjetividade; é absorvido dentro daquilo que perde, mas não se entrega senão ao que quer fazer; é inocente porque não é o que é; e culpado de ser o que não é. ${ }^{6}$

À medida que se destaca a proximidade central entre o tema homem e verdade, passamos a enxergar as modificações implicadas nas transformações de concepções da própria verdade, prenunciando a preocupação nodal dos anos oitenta acerca da subjetividade como relação com a verdade. Mas, em nossa interpretação, foi a História da loucura que lançou as bases para a consecução deste eixo de ocupação, pois levou Foucault a notar que, do período Clássico à emersão do homem moderno, "o ser humano não se caracteriza por uma certa relação com a verdade; mas ele detém, como pertence ele próprio, ao mesmo tempo aberta e fechada, a uma verdade" ${ }^{7}$. E quais as implicâncias disto?

Pertencer a uma verdade é encontrar-se num tipo de saber ordenado, num espaço histórico delimitado que, no entanto, arregimenta os fundamentos e condições possíveis "que se oferecem nas coisas como sua lei interior" ${ }^{\prime 8}$ ou, em outros termos, é o que permite o modo de ser de certas empiricidades tornarem-se conhecidas pela experiência e pensamento. Ao examinar as diferentes cenas das empiricidades concernentes ao Ocidente, não nos deparamos apenas com o conjunto de leis patentes na interioridade de cada fenômeno sutil e escandalosamente visível que vieram a caracterizar o incontornável de nosso pensamento. Mas podemos avançar no sentido de explicar a "mecânica de um processo histórico" 9 que, como Foucault gostava de enfatizar, tendia a uma sujeição persistente e incompleta, pois o

\footnotetext{
${ }^{4}$ Ibidem, p. 653.

${ }^{5}$ Ibidem, p.649.

${ }^{6}$ Ibidem, p.651-653.

${ }^{7}$ Ibidem, p. 653 .

${ }^{8}$ FOUCAULT, M. As palavras e as coisas, p.XVI.

${ }^{9}$ FOUCUALT, M. Os anormais, p.229.
} 
saber que pesa na confluência das práticas de nossa cultura não somente ordena o jogo de representação do homem, como confere a ele códigos ordenadores e limitantes para os seus modos de ser. Assim, implicância necessária, vemos que, desde o momento em que a História ${ }^{10}$ tornou-se "o modo de ser fundamental das empiricidades, aquilo a partir do que elas são firmadas, postas, dispostas e repartidas no espaço do saber para eventuais conhecimentos e para ciências possíveis", a prática histórica não cessou de denunciar o ritmo crescente dos saberes sujeitados que falam das próprias experiências de subjetividades sujeitadas. "Por saberes sujeitados", diz-nos Foucault, "eu entendo igualmente toda uma série de saberes que estavam desqualificados como saberes não conceituais, como saberes insuficientemente elaborados: saberes ingênuos, saberes hierarquicamente inferiores, saberes abaixo do nível do conhecimento ou da cientificidade requeridos" ${ }^{\prime 1}$. Não é à toa, assim, que a instauração de uma prática historiadora na vertente de uma reviravolta de saber será imprescindível para liberar os "conteúdos históricos que foram sepultados, mascarados em coerências funcionais ou em sistematizações formais" "12. Ao que nos parece, a peculiaridade e multiplicidade de seus temas e abordagens caminham nesta direção.

Ora, será neste contexto, poderíamos dizer pressuposto teórico do pensamento foucaultiano, que a subjetividade emergirá como problemática sob a perspectiva de uma história que pretende se desraigar das formas condicionadas de saber. Essa idéia, aliás, é estofo da determinação na construção paulatina, por meio de vários contornos, desvios, retomadas e superações, da concepção de história que leva em conta as mudanças metodológicas exigentes para esculpir a heterogênese das questões históricas responsáveis por uma análise e formulação de subjetividade. Cremos que o objetivo a fortiori é afastar-se constantemente dos processos de um saber sujeitado que pudesse servir de referência na compreensão dos temas atinentes à evidência de um tipo de sujeito cujo saber histórico e filosófico não cansou de reproduzir ou sujeitar. Tanto é que podemos "dizer que toda a

\footnotetext{
${ }^{10}$ No contexto da obra As palavras e as coisas, a História maiúscula se refere à "região mais erudita, mais informada, mais desperta, mais atravancada talvez de nossa memória; mas é igualmente a base a partir da qual todos os seres ganham existência e chegam à sua cintilação" (Cf. p. 300). É evidente que em Foucault o que encontramos é uma história minúscula, ou seja, relacionada, grosso modo, aos acontecimentos segundo as suas disposições manifestas, sem a pretensão da ação global da disciplina História (Cf. p. 298). Em Foucault, como acentua Jacques Le Goff, a "história com um pequeno 'h', história dos historiadores" está para um campo metodológico da história, enquanto que a "História com um grande ' $H$ " está para a evolução das sociedades humanas que o historiador procura dominar como objeto de uma disciplina, de um saber. Ainda neste aspecto, concordamos com Le Goff que tal dificuldade de vocabulário reflete os nódulos do pensamento acerca da História, mas gostaríamos de deixar claro que não vemos uma alusão de que a História maiúscula, em Foucault, necessariamente se reporte a uma "evolução das sociedades humanas", como interpreta Le Goff. (Cf. LE GOFF, J. Foucault et la "nouvelle histoire". In. Au risque de Foucault. Paris: Centre George Pompidou, 1997, p.129139).

${ }^{11}$ FOUCAULT, M. Em defesa da sociedade, p. 12.

${ }^{12}$ Ibidem, p. 11.
} 
civilização ocidental foi sujeitada, e os filósofos não fizeram outra coisa senão estabelecer a constatação, em referência a todo pensamento e toda verdade da consciência, do Eu (Moi), do Sujeito"13. Porém, quando se leva em consideração que "o sujeito não é um, mas cindido, não soberano, mas dependente, sem origem absoluta, mas função que não cessa de modificarse"14, fica claro para nós que, ao longo da obra de Foucault, estão em pauta os desdobramentos das cenas históricas que nos levam ao entendimento não somente do tipo de sujeito problematizado, todavia, quadro semelhante, às formas de os campos de subjetividade implicadas nesta concepção, que não cessa de se transformar na medida de um percurso que não se pretende acabado ${ }^{15}$.

Ainda a propósito desta questão, é como se Foucault convocasse, a cada vez, novas plataformas capazes de elevar o seu observatório num limite ainda mais altivo. Esforçando-se para plasmar uma prática historiadora longe dos saberes sujeitados, vê no horizonte a dificuldade essencial para a qual se dirige: "o homem de que nos falam e que nos convidam a libertar já é em si mesmo o efeito de uma sujeição bem mais profunda que ele"16. Esta sujeição profunda representa o jogo e trama invisíveis das condições históricas latentes da constituição da subjetividade contemporânea que necessitam ser investigadas desde a sua raiz. As contribuições decisivas de Foucault colocam-se em duas perspectivas distintas: em sua profundidade e em sua extensão em torno "de práticas que constituem uma espécie de fenômeno extremamente importante, não somente na história das representações nem na história das noções ou teorias, mas na própria história da subjetividade ou, se quisermos, na história das práticas da subjetividade" ${ }^{17}$. Mesmo que o contexto deste excerto remetesse Foucault ao epimeleia heautou grega, ou seja, o cuidado de si mesmo, como transposição ou superação do conhecer a si mesmo, notadamente no sentido moderno, ou seja, do ponto de vista do conhecimento, de nossa parte, vemos nesta referência uma chave importante nas transmutações de temas que orbitam na constituição de uma história da subjetividade. Tanto é

\footnotetext{
${ }^{13}$ FOUCAULT, M. Qu'est-ce qu'un auteur. Dits et Écrits I, No 69, 1969, p.789.

${ }^{14}$ Ibidem, Id.

${ }^{15}$ Ao colocarmos a obra de Foucault no estatuto de que as modificações ocorridas ao longo de sua produção é fruto de uma reproblematização da subjetividade ocidental, nos afastamos do nível de interpretação que enfatiza uma dinâmica entre o desaparecimento e o retorno do sujeito. Podemos destacar, como exemplo, Dosse, o qual considera que, a partir de 1976, Foucault vai "problematizar aquilo que até então ele evitara e minorara, a ponto de fazê-lo desaparecer de seu campo filosófico: o sujeito" (cf. DOSSE, F. A história à prova do tempo. São Paulo: Unesp, 1999. p.227). É verdade que, sobretudo nas obras História da Loucura e O Nascimento da Clínica, o sujeito não está relevado, mas isto se deve justamente pelo fato de Foucault já questionar um tipo de interpretação acerca da concepção de sujeito. Não quer dizer, contudo, como será aduzido mais adiante, que não houvesse uma problematização acerca do sujeito/subjetividade. Foucault, a nosso ver, já enfatizava que o anonimato do sujeito é uma das características mais marcantes dos processos históricos de sujeição na história do Ocidente.

${ }^{16}$ FOUCAULT, M. Vigiar e Punir, p.31.

${ }^{17}$ FOUCAULT, M. A hermenêutica do sujeito, p.15.
} 
que, no mesmo curso denominando A hermenêutica do sujeito de 1982, a posse da seguinte argumentação assinala favoravelmente para a nossa interpretação:

[...] no fundo, a questão que me coloco é a seguinte: como pôde constituir-se, através deste conjunto de fenômenos e processos históricos que podemos chamar de nossa "cultura", a questão da verdade do sujeito? Como, por que e a que preço, temos nos empenhado em sustentar um discurso verdadeiro sobre o sujeito, sobre o sujeito que não somos, enquanto sujeito louco ou sujeito delinqüente, sobre o sujeito que, de modo geral, nós somos enquanto falamos, trabalhamos, vivemos, e enfim sobre o sujeito que, no caso particular da sexualidade, nós somos direta e individualmente para nós mesmo? ${ }^{18}$

Com isto, além de saltar aos olhos o corte transversal que Foucault está fazendo em sua obra em relação à temática da subjetividade, gostaríamos de destacar, já nos adiantando em relação a um aspecto nodal concernente à nossa tese, a noção de crítica, o seguinte trecho que o manuscrito deste curso traz, ausente, portanto, do corpo da argumentação central: "Se a questão da crítica é a de saber 'sob que condições gerais pode haver verdade para o sujeito', a questão que gostaria de colocar é a seguinte: 'sob que transformações particulares e historicamente definíveis, o sujeito teve que se submeter a si mesmo para que houvesse a injunção de dizer a verdade sobre o sujeito?"19 Segundo a nossa hipótese interpretativa, é o entendimento dispensado a estas transformações particulares e historicamente definíveis a chave de compreensão das distintas questões que Foucault elabora, contudo, sem se afastar da subjetividade. Sendo assim, para reverter de maneira completa o discurso que se pode elaborar acerca do sujeito, forjando uma nova perspectiva na acepção e entendimento de sua constituição, julgamos que Foucault cavará fossos para determinar seus próprios caminhos, quer dizer, forjará um princípio geral de heterogeneidade que consiste no princípio de que "a história de uns não é a história dos outros" ${ }^{20}$. Isto equivale a dizer que somos permitidos a ver na história uma função de contra-história, pois, segundo o seu julgamento, “o discurso histórico, o discurso dos historiadores, essa prática que consiste em narrar a história permaneceu por muito tempo o que era decerto na Antiguidade e o que era ainda na Idade Média: ela permaneceu por muito tempo aparentada com os rituais de poder", na mesma

\footnotetext{
${ }^{18}$ Ibidem, p.308.

${ }^{19}$ Ibidem, Id. Neste aspecto, embora seja possível interpretar a obra de Foucault no sentido da "questão da verdade", como bem faz Gros, destacando que "o homem é fundamentalmente refletido em sua obra (a de Foucault) como animal de verdade (animal de vérité), julgamos a verdade e os jogos que se estabelecem ao seu redor como um dos componentes importantes da subjetividade ocidental. No nosso caso, este é o "fio vermelho" da obra, para nos valermos de uma outra expressão de Gros, e não a temática da verdade. (Cf. GROS, F. Michel Foucault, une philosophe de la vérité. In. Michel Foucault: philosophie anthologie. Paris: Gallimard/Folio, 2004, p.11-25).

${ }^{20}$ FOUCAULT, M. Em defesa da sociedade, p.81.
} 
proporção em que "a história como os rituais, como as sagrações, como os funerais, como as cerimônias, como os relatos legendários, é um operador, um intensificador de poder" 21 . Entrementes, a alusão que nega, concomitantemente, pode afirmar. Em outros termos, se houve na história o domínio de relatos do triunfo de uns, doravante haverá a imperiosa tarefa de fazer emergir os relatos, pois da submissão de outros. Podemos dizer que se trata de uma tarefa que se põe, em revanche, na perspectiva de redistribuir o espaço outrora dado à todapoderosa dominação do tempo e espaço por uma história unívoca.

Para tanto, julgamos que a cadência e o compasso não podem, por conseguinte, nunca serem os mesmos concernentes às mutações temáticas, noções empregadas e abordagens desferidas, porque há uma "luz que divide, que aclara de um lado, mas deixa na sombra, ou lança para a noite, uma outra parte do corpo social" 22 , e a penumbra não pode ser tomada de uma só vez, pois alude às várias histórias diferentes que não conciliam “vários tempos, várias durações, várias velocidades", ao contrário, “embaralham-se uns com os outros"23. A contrahistória é o paroxismo delator daquele sofrimento anunciado por Nietzsche: sofremos de uma febre histórica delirante; ela quer "mostrar que as leis enganam, que os reis mascaram, que o poder ilude e que os historiadores mentem"; ela "será a decifração de uma verdade selada"24; ela será a decifração das dissimetrias. A este respeito, é preciso deixar claro que a inventividade de Foucault concernente ao uso da história como função de análise não está suspensa no ar. Ao contrário, em partes ecoa uma série de transformações que vinham ocorrendo nos paradigmas das ciências humanas e sociais do século XX; em partes problematiza tais transformações; em partes nega e contra-ataca outras transformações. É o caso, por exemplo, de lembrarmos que a História da loucura, de 1961, situa-se "no momento em que a antropologia interroga sobre o Outro do Ocidente, exumando as sociedades primitivas da ignorância na qual o pensamento eurocêntrico as manteve durante muito tempo" ${ }^{25}$. Além disto, a fortuna estruturalista, confessadamente devedora a Dumézil, estará presente até em $O$ nascimento da clínica e também em As palavras e as coisas, tentando “descobrir normas estruturadas de experiência cujo esquema possa ser encontrado com modificações em níveis diversos" ${ }^{26}$. Todavia o que mais pesa sobre o contexto inicial de sua obra ou da formação fundamental de sua concepção de história são as modificações realizadas na própria concepção e abordagem da história desde os Annales e também do que fícou

\footnotetext{
${ }^{21}$ Ibidem, p.76 e 77.

${ }^{22}$ Ibidem, p.81-82.

${ }^{23}$ FOUCAULT, M. La scène de la philosophie. Dits et Écrits III, No 234, 1978, p.581.

${ }^{24}$ FOUCAULT, M. Em defesa da sociedade, p.84.

${ }^{25}$ Cf. DOSSE, F. A história à prova do tempo. São Paulo: Unesp, 1999, p.196.

${ }^{26}$ FOUCAULT, M. La folie n'existe que dans une société. Dits et Écrits I, N ${ }^{\circ} 05,1961$, p. 168.
} 
conhecido como História Nova, nem sempre devidamente reconhecidos por Foucault. Aliás, o seu percurso, em parte do ponto de vista das superações de referências teóricas, em parte das cisões metodológica, dos rompantes temáticos, enfim, em boa medida, acompanham as múltiplas abordagens históricas que colocavam a sua ênfase no desaparecimento dos atores sociais, caso nítido de História da loucura, O nascimento da clínica, As palavras e as coisas; no retorno dos atores sociais, caso dos estudos sobre as Estratégias de poder, Vigiar e punir e História da sexualidade I destacam-se; e, finalmente, ênfase nas condutas dos atores como forma de oferecer possibilidades de contorno e mobilidade aos atores sociais, caso dos dois últimos volumes da História da sexualidade ${ }^{27}$. Com isto, não pretendemos tirar de Foucault o mérito como teórico e praticante da história descontínua, mas acentuarmos, mesmo que incipientemente, o quanto o filósofo francês é devedor de um campo de questões que foram as condições essenciais para balizar o espectro de suas novidades. Isso não podemos ignorar.

Mas como, então, escrever esta história? Em nosso entender, a indagação é o núcleo ativador do revisionismo foucaultiano que explode a "idade da história" como dispositivo conceitual e narrativo próprio capaz de fornecer um acabamento de sentidos ${ }^{28}$. Desde então, a história será uma dobradiça irregular destinada ao conhecimento de temáticas irregulares que, se tomada como conjunto, disporão ao pensamento a irregularidade fundamental da temática da subjetividade. É em função deste cenário, então, que Foucault vai "libertar-se de todo um jogo de noções que diversificam, cada uma à sua maneira, o tema da continuidade" ${ }^{29}$. O tempo não pode ser, assim, entendido de modo regular, como se fossem possíveis estender-se “até as menores parcelas da natureza o princípio e o movimento da destinação humana" ${ }^{30}$.

As temáticas que são construídas, propositalmente instruídas na direção de uma contra-história, passam a revelar o revés, a porosidade e as asperezas de uma

[...] grande história plana, uniforme em cada um de seus pontos, que teria arrastado num mesmo fluir, numa mesma queda ou numa mesma ascensão, num mesmo ciclo,

\footnotetext{
${ }^{27}$ Devemos esta interpretação a Jacques Revel. (Cf. REVEL, J. Machines, stratégies, conduites: ce qu'entendent les historiens. In. Au risque de Foucault. Paris: Centre George Pompidou, 1997, p.109-128)

${ }_{28}$ Colocar-se contra a "idade da história", uma expressão de Rancière, é ativar uma forma de fazer história longe e distinta das narrativas homogêneas que "não restituem nenhuma aspereza, nenhum lugar-fora ou não-lugar nos quais as palavras poderiam ser ditas", como assinala Farge. Desta forma, "a idade da história tem sido por onde os historiadores inventaram um dispositivo conceitual e narrativo próprio para neutralizar o excesso de palavras" (Cf. FARGE, A. Des lieux pour les histoires. Paris: Seuil, 1997, p.88-89). Conforme nossa interpretação, Foucault trabalha não na direção da narrativa, descrição ou inscrição equivalente de sentidos territorializados. Ao contrário, desfaz com a escrita, desterritorializa, desloca, devolve à palavra o seu excesso a partir do acontecimento desclassificado, ou melhor, até então desconhecido.

${ }^{29}$ FOUCAULT, M. A arqueologia do saber, p.24.

${ }^{30}$ FOUCAULT, M. As palavras e as coisas, p.508.
} 
todos os homens e, com eles, as coisas, os animais, cada ser vivo ou inerte, e até os semblantes mais calmos da terra ${ }^{31}$.

Com isto, Foucault pertence à seara dos pensadores que questionam os grandes blocos, períodos inequívocos da identidade baseada na repetição, a evidenciar a lenta e contínua evolução de uma civilização identificada pelo jogo do mesmo, quer dizer, das estruturas econômicas, estabilidades sociais, comportamentos políticos, hábitos técnicos, enfim, tudo o que pudesse ser submetido a um mesmo tipo de transformação. Não menos diferente, idéias e temas associados à gênese, sucessão e encadeamento dos fatos; totalização de recortes que, de uma maneira ou de outra, acabam por fazer da história uma disciplina dos começos e dos fins, descrevendo o que insiste ser visível, reconstituindo desenvolvimentos lineares, não comporão o campo gravitacional de questões a girar em torno do foco foucaultiano ${ }^{32}$.

Sob este horizonte, encontramos a construção de um novo regime de visibilidade enquanto história, trazendo inevitavelmente uma vastidão de conseqüências que persistirão no decurso da empresa de Foucault. Em um movimento cada vez mais acentuado, desde a História da Loucura, podemos verificar o relevo do caráter historiador que se afasta das “cronologias e sucessões históricas de toda perspectiva do 'progresso', restituindo à história da experiência um movimento que em nada se dá à finalidade do conhecimento ou à ortogênese do saber" ${ }^{33}$. Desta afirmação, a questão a ser sublinhada é o movimento enquanto "fenômeno de uma descontinuidade" 34 . Isto significa que, por ser o elemento fundamental de análise histórica, ela será constituída sob o regime de "uma operação deliberada do historiador", a fim de fixar os períodos que lhes são convenientes; será também o resultado de um trabalho de descrição, pois o que o historiador empreende descobrir "são limites de um processo, o ponto de inflexão de uma curva, a inversão de um momento regulador, as fronteiras de uma oscilação, o umbral de um funcionamento, a emergência de um mecanismo, o instante de desordem (dérèglement) de uma causalidade circular"; enfim, o movimento da

\footnotetext{
${ }^{31}$ Ibidem, Id.

${ }^{32}$ É preciso ter isto em mente, pois é justamente esta perspectiva que embasa e justifica os desencontros aparentes das obras de Foucault. Em nosso juízo, o desenvolvimento da obra aprofunda estas questões cada vez mais, o que provoca em muitos leitores o que poderíamos designar de vertigem de coerência, algo que, nos termos de Jacques Revel, decorre do fato de muitos "historiadores - e não somente eles - não terem prestado atenção", ou ainda, ter entrado "nos textos de Foucault em momentos diversos, com preocupações e motivações particulares, produzindo vários Foucault, às vezes mal reconhecido, em todo caso dificilmente compatível e cumulável” (Cf. Opus cit. p.110). É evidente que não asseveramos com Revel na direção de uma apologia contrária às incongruências contidas na obra de Foucault, como aduziremos à frente. Contudo ressaltamos que é característico da obra justamente um tipo de incongruência, pois, seguindo a nossa linha interpretativa, ela aborda um dos temas mais complexos da história ocidental: a subjetividade.

${ }^{33}$ FOUCAULT, M. Histoire de la folie, p.165-166.

${ }^{34}$ Ibidem, p. 144.
} 
descontinuidade não cessará de se especificar, já que "toma uma forma e uma função diferentes segundo o domínio e o nível aos quais se determinam"35.

Ao conceber a sua tarefa desde este prisma, Foucault não somente tenta avançar na explicação dos fenômenos sutis de diferentes maneiras, como também, aliás, focalizará “datas históricas precisas" ${ }^{36}$, ao que nos parece, lançando mão de uma visão ampla de seus trabalhos até meados dos anos de 1970, com o intuito de forjar a história da subjetividade que, como afirma, teria sido "empreendida estudando as divisões realizadas na sociedade em nome da loucura, da doença, da delinqüência, e seus efeitos sobre a constituição de um sujeito razoável e normal" ${ }^{37}$. Entrementes, seria temerário, a propósito desta questão, não ressaltar a démarche operada na obra a partir dos cursos no Collège de France que contemplaram a temática da governamentalidade. Entrecruzando "uma história da subjetividade e uma análise das formas de 'governamentalidade",38 numa ótica diferente, Foucault anuncia a intenção de se aprofundar nos estudos que contemplassem "a história do 'cuidado' e das 'técnicas' de si”, portanto notemos bem a diferença:

[...] uma maneira de fazer a história da subjetividade; porém, não mais através da separação entre loucos e não loucos, doentes e não doentes, delinqüentes e não delinqüentes, não mais através da constituição de campos de objetividade científica, dando lugar ao sujeito que vive, que fala e que trabalha. Mas através do empreendimento e das transformações, na nossa cultura, das "relações consigo mesmo", com seu arcabouço técnico e seus efeitos de saber. Seria possível, assim, retomar num outro aspecto a questão da "governabilidade": o governo de si por si na sua articulação com as relações com o outro (como é encontrado na pedagogia, nos conselhos de conduta, na direção espiritual, na prescrição dos modelos de vida etc) ${ }^{39}$.

Ora, a diferença decisiva de tônica opera numa direção muito precisa, a nosso ver. Com ela são sublinhadas as transformações do descontínuo, temas aparentemente desconexos entre si, mas que evocam a incidência oposta da história contínua, ou seja, longe de "fazer da consciência humana o sujeito original de todo saber e de toda prática” ${ }^{, 40}$, cuja litania, sob os auspícios da totalização do tempo, protegeu, "contra todas as descentralizações, a soberania

\footnotetext{
${ }^{35}$ Seguimos a argumentação de Foucault em Sur l'archéologie des sciences. Réponse au Cercle d'épistémologie. O texto, datado de 1968, é fruto do esforço do filósofo de se colocar em face de um conjunto de questões referentes à periodização, configuração epistêmica, método de trabalho, enfim, propostas pelo Círculo de epistemologia. Este texto servirá de plataforma para a obra A arqueologia do saber, de 1969. In. Sur l'archeologie des sciences. Réponse au Cercle d'épistémologie. Dits et Écrits I, No 59, 1968, p.698.

${ }^{36}$ FOUCAULT, M. Os anormais, p.415.

${ }^{37}$ FOUCAULT, M. Subjectivité et vérité. Dits et Écrits IV, № 304, 1981, p.214.

${ }^{38}$ FOUCAULT, M. Subjetividade e verdade (1980-1981). In. Resumo dos cursos do Collège de France; p.110.

${ }^{39}$ Ibidem, p.111.

${ }^{40}$ FOUCAULT, M. Sur l'archéologie des sciences. Réponse au Cercle d'épistémologie. Dits et Écrits I, $\mathrm{N}^{\circ} 59$, 1968, p.699.
} 
do sujeito e as figuras gêmeas da antropologia e do humanismo" ${ }^{41}$. Nessa medida, o que Foucault busca é ampliar a sua distância dos referenciais históricos postos na dimensão da história da mentalidade e das idéias.

Quanto à história da mentalidade, distancia-se das análises que primaram por "estabelecer entre fenômenos simultâneos ou sucessivos uma comunidade de sentidos, de laços simbólicos, um jogo de semelhanças e de espelhos" ${ }^{\text {"42 }}$, por entender que os feixes polimorfos de correlação entre os pensamentos dos homens e seus discursos não dependeriam de uma simetria entre condições históricas silenciosas e comportamentos correspondentes. Preocupado mais com a transformação de diferenças efetuadas à guisa de um acontecimento particular, levando em consideração a existência de enunciados que tornaram possíveis um acontecimento e não outro em seu lugar, as condições de sua emergência singular, Foucault não endossará "uma história do espírito, segundo a sucessão de suas formas ou segundo a espessura de suas significações sedimentadas" 43 . Assim, o comportamento humano não é fruto de uma mentalidade de uma época referente a uma consciência obscura ou explícita, da qual não se pode escapar. Ao contrário, será ao cabo do amadurecimento da arqueologia enquanto método que ele passará a interrogar

não os discursos sobre o que, silenciosamente, eles querem dizer, mas sobre o fato e as condições de suas aparições manifestas; não sobre os conteúdos que eles podem absconder, mas sobre as transformações que efetuaram; não sobre o sentido que se mantém neles como uma origem perpétua, mas sobre o campo onde eles coexistem, permanecem e se apagam $^{44}$.

À vista disto, o discurso será tomado não como "o lugar da irrupção da subjetividade pura", mas como "um espaço de posições e funcionamentos diferenciados para os sujeitos"

\footnotetext{
${ }^{41}$ FOUCAULT, M. A arqueologia do saber, p. 15.

${ }^{42}$ FOUCAULT, M. Sur l'archéologie des sciences. Réponse au Cercle d'épistémologie. Dits et Écrits I, No 59, 1968, p.701. A noção de descontinuidade na história não é criação de Foucault. Devedor do contexto referencial do século XX, Foucault, como bem aponta Le Goff, ficou fascinado para a questão a partir da obra $L a$ Méditarranée (1949) de Braudel (Cf. LE GOFF, J. Foucault et la "nouvelle histoire". In Au risque de Foucault. Paris: Centre George Pompidou, 1997, p.134). Mas, ao levar às últimas conseqüências a descontinuidade, no caso da história das mentalidades, o nosso filósofo torna-se "teórico e praticante da descontinuidade", o que não deixará de refletir na estrutura de seu percurso intelectual. Assim, diante da história das mentalidades, referenciada pela "sucessão dos horizontes mentais", compreendidos como "um empilhamento de camadas sedimentares definidas pelo sistema de suas diferenças, e separadas por umbrais, rupturas, 'revoluções' ou rearranjos, cada um obliterando os que são precedentes" (Cf. REVEL, J. Machines, stratégies, conduites: ce qu'entendent les historiens. In. Au risque de Foucault. Paris: Centre George Pompidou, 1997, p.114), isso não fará sentido a Foucault, pois desde a arqueologia encontramos algo profundamente diferente na dimensão dos discursos, pois estes só nascem daquilo que excluem e, portanto, permanecem inseparáveis de sua constituição e de seu desdobramento.

${ }^{43}$ FOUCAULT, M. Réponse à une question. Dits et Écrits I, № 58, 1968, p.682.

${ }^{44}$ Ibidem, p.682.

${ }^{45}$ Ibidem, p.680.
} 
Quanto à história das idéias, Foucault julga que seus temas repisam formas de análises que prescindem da gênese, continuidade e totalização, justamente por ser a história das idéias "a disciplina dos começos e dos fins, a descrição das continuidades obscuras e dos retornos, a reconstituição dos desenvolvimentos na forma linear da história»46. Por conseguinte, as tentativas de se elaborar um tipo de interpretação que busca o discurso oculto, revelador de uma profundidade mais essencial é o que permite a determinação de novidade segundo a perspectiva das idéias. Mas, para Foucault, trata-se de buscar definir "não os pensamentos, as representações, as imagens, os temas, as obsessões que se ocultam ou se manifestam nos discursos; mas os próprios discursos, enquanto práticas que obedecem a regras" ${ }^{״ 7}$. Ademais, não se pretende reconstituir a história sob a égide de uma transição contínua e lenta que pouco a pouco visou notoriedade a um domínio duplo de valores, sempre submetidos à mesma análise, em que todo elemento pudesse ser caracterizado como "antigo ou novo; inédito ou repetido; tradicional ou original; semelhante a um tipo médio ou desviante" 48 . Doravante, ao contrário, a especificidade da análise depende da ação abrupta que desfecha numa modalidade a ser historicizada, cujo relevo é de uma regularidade não mais definitiva. A farta argumentação do filósofo é explícita nesta direção:

não se deve mais procurar o ponto de origem absoluta, ou de revolução total, a partir do qual tudo se organiza, tudo se torna possível e necessário, tudo se extingue para recomeçar. Temos que tratar de acontecimentos de tipos e de níveis diferentes, tomados em tramas históricas distintas; uma homogeneidade enunciativa que se instaura não implica de modo algum que, de agora em diante e por décadas ou séculos, os homens vão dizer e pensar a mesma coisa; não implica, tampouco, a definição, explícita ou não, de um certo número de princípios de que todo o resto resultaria, como conseqüência ${ }^{49}$.

Assim, se para a história das idéias toda possibilidade de diferenças ou contradições históricas é entendida como uma "ilusão de uma unidade que se oculta ou que é ocultada" 50 , no pensamento de Foucault, as contradições são entendidas como "objetos a serem descritos por si mesmos, sem que se procure saber de que ponto de vista se podem dissipar ou em que nível se radicalizam e se transformam de efeitos em causas" ${ }^{\prime 1}$.

Admitindo este cenário, podemos sustentar que, ao longo da própria obra, somos interditados de procurar uma sistematicidade e uma ordem das sucessões cronológicas que

\footnotetext{
${ }^{46}$ FOUCAULT, M. A arqueologia do saber, p.158.

${ }^{47}$ Ibidem, p. 159.

${ }^{48}$ Ibidem, p. 160.

${ }^{49}$ Ibidem, p. 167.

${ }^{50}$ Ibidem, p. 172.

${ }^{51}$ Ibidem, p.174.
} 
evidenciassem com clareza e sem problemas o foco subjetividade. Além de ingênua, tal tomada de posição deporia contra os efeitos prático-teóricos que o tratamento dispensado à história instaura na própria trajetória das análises que privilegiam os espaços de dissensão e heterogeneidade. Neste caso, não se busca a unidade, efeito de escansão, cujo horizonte ao qual se dirige pudesse ser o de "uma ciência, uma mentalidade, uma cultura" subjetividade, acrescentaríamos nós. A história deixaria de ter um efeito unificador, portanto, para acentuar um efeito multiplicador, já que "não se destina a reduzir a diversidade dos discursos nem a delinear a unidade que deve totalizá-los, mas sim a repartir sua diversidade em figuras diferentes" ${ }^{\prime 53}$. Se colocamos a história nestes termos, é justamente porque sustentamos que, no caso da subjetividade, Foucault visa a armar o jogo das diferentes perspectivas históricas a nos afastar de uma análise e abordagem unívocas e essencialistas referentes ao sujeito ocidental e a seus jogos possíveis de constituição. Não seria inoportuno admitir que está em questão o desmantelamento de um abrangente projeto históricotranscendental caracterizado pela tentativa de

procurar, além de toda manifestação e de todo nascimento histórico, uma fundação originária, a abertura de um horizonte inesgotável, um projeto que seria um recuo em relação a todo acontecimento, e que manteria por intermédio de um esboço sempre desatado a história de uma unidade que não se conclui ${ }^{54}$.

Em nossa consideração, o delineamento deste contexto representa o desenvolvimento do campo no qual o pensamento do filósofo francês se situa com o intuito de operar um desengate de certos procedimentos históricos que poderiam ser resumidos na idéia de uma história global. Quer dizer, buscando transformações particulares e historicamente definíveis, Foucault coloca em dúvida os postulados que procuram "reconstituir a forma de conjunto de uma civilização, o princípio - material ou espiritual - de uma sociedade, a significação comum a todos os fenômenos de um período, a lei que explica sua coesão - o que se chama

\footnotetext{
52 Ibidem, p. 183.

${ }^{53}$ Ibidem, Id.

${ }^{54}$ FOUCAULT, M. Réponse à une question. Dits et Écrits $I, N^{\circ} 58,1968$, p. 675. Quando Foucault afirmou que “o mundo ignora toda lei” (Cf. La vérité et les formes juridiques. Dits et Écrits I, 1954-1975, N 139, 1974, p.1414), assinalava para a tarefa do pensamento trabalhar na direção da incansável l'oeuvre à venir, pois, como bem comenta a historiadora Farge, "nós vivemos sem referências nem coordenadas originárias numa miríade de acontecimentos perdidos: assim, desde a origem, não se teve a ordem, nem a razão, nem mesmo a liberdade. Estes postulados, longe de fornecer uma bruma definitiva sobre o caminho do historiador, permitem construir um olhar novo sobre o que Foucault denominou de desordem" (cf. FARGE, A. Des lieux pour l'histoire, p.38). Com isto, chamamos a atenção para o aspecto das intensidades diferentes, os furores secretos da obra que levam em consideração os mecanismos do jogo de desmontagem das linhas definidoras do entendimento das questões históricas atinentes aos mais distintos atores sociais.
} 
metaforicamente o 'rosto' de uma época" ${ }^{, 55}$. Assim, é com determinação que relações homogêneas, os suportes interpretativos únicos e atinentes às mesmas formas e às grandes unidades, cederão lugar a uma historicidade que refuta as análises como domínio de significantes, isto é, não se busca o sentido de um acontecimento: "a história não tem sentido, o que não quer dizer que é absurda ou incoerente. Ela é, ao contrário, inteligível e deve ser analisada até o seu menor detalhe: mas segundo a inteligibilidade das lutas, das estratégias e das táticas" $" 56$.

Este quadro nos indica que as relações existentes na história são entrecruzadas por uma mobilidade belicosa, ou seja, não pertencem a uma calmaria estática de sentidos que, globalmente, poderiam sugerir uma coesão dos fatos. Devemos notar todos estes problemas, aliás, para, doravante, podermos circunscrever a empresa de Foucault numa história geral, em que é sublinhada, mais uma vez, a idéia de quadros, senão vejamos:

o problema que se apresenta - e que define a tarefa de uma história geral - é determinar que forma de relação pode ser legitimamente descrita entre essas diferentes séries; que sistema vertical podem formar, qual é, de umas às outras, o jogo das correlações e das dominâncias; de que efeito podem ser as defasagens, as temporalidades diferentes, as diversas permanências; em que conjuntos distintos certos elementos podem figurar simultaneamente; em resumo, não somente que séries, mas que "séries de séries" - ou, em outros termos, que "quadros" - é possível constituir. Uma descrição global cinge todos os fenômenos em torno de um centro único princípio, significação, espírito, visão de mundo, forma de conjunto; uma história geral desdobraria, ao contrário, o espaço de uma dispersão ${ }^{57}$.

\footnotetext{
${ }^{55}$ FOUCAULT, M. A arqueologia do saber, p.11. Que fique claro, contudo, que é possível concebermos uma certa materialidade existente na história. Aliás, tal complexidade é abordada por Balibar, que tem por mérito enxergar a materialidade da história, em Foucault, pelo acontecimento, com o que concordamos, pois assim fica claro que somos interditos de pensar em uma materialidade, já que o acontecimento é múltiplo e fragmentado. Todavia, ao se referir ao materialismo dos corpos, indivíduos históricos que têm seus "corpos sujeitados às disciplinas, às normas e às regulamentações políticas" (Cf. BALIBAR, É. Foucault et Marx: l'enjeu du nominalisme. In. Michel Foucault philosophe. Rencontre internationale. Paris, 9, 10, 11 janvier 1988, p.74) esquece-se de que os corpos não são dados como uma afirmação material. Se devemos buscar uma materialidade na história, é de suma importância que se leve em consideração a relação de forças que envolve uma gama enorme de investimento na constituição própria dos corpos. Assim, materialidade não endossa um princípio material, mas, no limite, um jogo de forças; materialidade imanente, portanto. No caso de Foucault, isto é justamente a relação deste jogo incansável que se põe à prova. Exemplo disto é a complexa passagem do primeiro volume de a História da sexualidade: "o objetivo da presente investigação é, de fato, mostrar de que modo se articulam dispositivos de poder diretamente ao corpo a corpo, a funções, a processos fisiológicos, sensações, prazeres; longe do corpo ter de ser apagado, trata-se de fazê-lo aparecer numa análise em que o biológico e o histórico não constituam seqüência, como no evolucionismo dos antigos sociólogos, mas se liguem de acordo com uma complexidade crescente à medida que se desenvolvem as tecnologias modernas de poder que tomam por alvo a vida. Não uma 'história das mentalidades', portanto, que só leve em conta os corpos pela maneira como foram percebidos ou receberam sentido e valor; mas 'história dos corpos' e da maneira como se investiu sobre o que neles há de mais material, de mais vivo" (História da sexualidade: a vontade de saber, p.142 - grifos nossos). O que há de mais material nos corpos é o que há na multiplicidade complexa da constituição histórica do que são. Portanto Foucault não nega a realidade material na história; mas não a vê de um modo somente.

${ }^{56}$ FOUCUALT, M. Entretien avec Michel Foucault. Dits et Écrits III, No 192, 1977, p.145.

${ }^{57}$ FOUCAULT, M. A arqueologia do saber, p.11.
} 
De fato, não concebemos que se distanciará das abordagens empreendidas por Foucault o tríplice eixo de incursões históricas privilegiando séries de séries, cujos pontos de inflexão e contato sublinham a dimensão descontínua de se pensar a história - saber, poder, experiências de subjetividades. Com isto, a questão preponderante será, ao que pensamos, a dos efeitos visíveis ou enunciados, que, em uma determinada série, são capazes de permitir ao pensamento a apreensão do acontecimento pontual abordado. Conseqüentemente, todo espaço de dispersão emergirá como núcleo de força motriz a atuar, em nosso entender, nas linhas que passam a constituir a multiplicidade de abordagens encarregadas de instilar as condições históricas diferentes - séries de séries - da temática da subjetividade, que não cessa de se recompor. Ocorre, contudo, que tal dinâmica não é delineada sem os seus impasses, dificuldades teóricas e redimensionamentos de enfoques. Aliás, a perspectiva da história geral, como intenta Foucault, nos permitirá entender a razão das modificações mais profundas encontradas em sua obra que, de uma forma ou de outra, faz dela um problema à medida que o termo problema consignará a própria tentativa de superação de abordagens teóricas e práticas à guisa de seu pensamento.

Não é sem sentido que a história como diagnóstico passa a ser considerada tarefa incoativa. Devemos entender por diagnóstico a relação direta com o presente, ou seja, as contribuições decisivas que o filósofo francês desenvolve na tentativa de "dizer o que somos atualmente e o que significa, na atualidade, dizer o que nós dizemos" ${ }^{, 58}$. Mapear, por assim dizer, as ambientações nas quais vivemos não significa encontrar as identidades ou essências do que somos, mas o que fazemos para ser o que somos. Trata-se de ver na história as ações e práticas - oficinas de produção - que, sob nossos pés, constituíram um "universo de pensamento, de discurso, de cultura" ${ }^{59}$ que tornaram as condições imprescindíveis para ser o que somos. Então, diagnosticar o presente equivale a "dizer que nosso presente é diferente e absolutamente diferente de tudo o que ele não é, quer dizer, de nosso passado"60. Sendo assim, o diagnóstico serve para nos mostrar as forças que atravessam o nosso momento de ser e que não conhecemos, ou pouco conhecemos, mas que ainda constituem nossa atualidade e persistem em agitá-la. Desde que concebemos a empresa de Foucault na dimensão do diagnóstico, duas conseqüências importantes se destacam. Com a primeira, nos afastamos de uma "história de soluções", isto é, não se pretende encontrar soluções de um problema presente na solução de um outro problema colocado em "uma outra época por pessoas

\footnotetext{
${ }^{58}$ FOUCAULT, M. “Qui êtes-vous professeur Foucault?”. Dits et Écrits I, No 50, 1967, p.606.

${ }^{59}$ Ibidem, p.613.

${ }^{60}$ FOUCAULT, M. Usage des plaisirs et techniques de soi. Dits et Écrits IV, № 338, 1983, p.556.
} 
diferentes"61. A tarefa é mais no sentido de "um trabalho de problematização e de perpétua reproblematização" ${ }^{62}$ que, em nosso caso, enfatizaria os movimentos da subjetivação coletiva e individual que não cessam de problematizar a nossa constituição. Com a segunda conseqüência, contudo, temos um alcance mais abrangente enquanto dimensão de problematização, pois concerne a todas as modificações que Foucault empreendeu em suas pesquisas. Em nosso entender, o campo difuso, irregular e erodido, baseado em pressupostos e referenciais teóricos tão díspares acabarão se dinamizando com o intuito de equipotencializar o papel da história como diagnóstico. Da História da loucura de 1961 até o terceiro volume de a História da sexualidade de 1984, as mais heteróclitas modificações serão processadas, perscrutando as erupções latentes responsáveis pelo cenário no qual o homem ocidental representa determinados papéis. Com a intenção de evidenciarmos este jogo, é imprescindível nos colocarmos dentro da dinâmica do vai-e-vem da obra.

\subsection{Campos de problematizações, campos de transformações}

É marcante, desde a História da loucura, a busca pelo entendimento de experiências que pudessem isolar e, ao mesmo tempo, trazer à tona as transformações das "relações da subjetividade e da verdade" ${ }^{\$ 3}$ solidamente encadeadas no cruzamento infinito de experiências em movimento. Certo de que a loucura sempre fascinou o homem, Foucault a tomará por objeto, com a finalidade de expor as engrenagens dos "caminhos estranhos do saber" que não somente um espaço moral de exclusão fora criado, como também um tipo de perigo aberto à razão do homem, pois, "se o homem pode sempre ser louco, o pensamento, como exercício da soberania do sujeito que se coloca no dever de perceber o verdadeiro, não pode ser insensato" ${ }^{65}$. Há um vazio que se constata na linha mal traçada do tempo que separará certas experiências da loucura de outras. É justamente no intervalo desta linha que somos capazes de encontrar o que ele denominou de "experiência singular" ou "experiência

\footnotetext{
${ }^{61}$ FOUCAULT, M. À propos de la généalogie de l'éthique: un aperçu du travail en cours. Dits et Écrits IV, $\mathrm{N}^{\mathrm{o}}$ 344, 1984, p.612.

${ }^{6}$ Ibidem, Id.

${ }^{63}$ FOUCAULT, M. Histoire de la folie, p.70.

${ }^{64}$ Ibidem, p.41.

${ }^{65}$ Ibidem, p.70.
} 
fundamental” ${ }^{16}$, responsáveis por modificar o vir-a-ser da realidade histórica do homem. No caso da loucura, leva-se em consideração que tal experiência emerge dos limites culturais impulsionados por forças internas que equivalem a "gestos obscuros, necessariamente esquecidos desde que realizados, para os quais uma cultura rejeita qualquer coisa que será para ela o Exterior" ${ }^{\circ 7}$. A loucura será a exterioridade de uma interioridade e vice-versa, oxímoro inerente a Foucault, reveladora de uma "rede subterrânea estabelecida que desenha as fundações secretas de nossa experiência moderna da loucura", aliás, sobre um "domínio assim estruturado" $" 68$.

Neste caso, o jogo óptico da loucura é devedor, desde o gesto mais incipiente do internamento e exclusão, mero fenômeno de superfície, de um sistema de operações subterrâneas que forja o pronunciamento da história ao retorno indefinido de seu limite cultural; em seu limite estruturado que "obedece regras que não são todas dadas à consciência" ${ }^{\circ 9}$. A nosso ver, a problemática que se ergue deste campo refere-se ao papel que a consciência exerceu no sujeito ocidental como ponto centralizador das atenções históricas, ou melhor, como material capaz de ensejar sentido aos acontecimentos. Mas, ao buscar a singularidade de um acontecimento que pudesse sublinhar os movimentos rudimentares de uma experiência, Foucault nos deixa transparecer o que não foi capturado pelo saber consciente que busca sentido, ao contrário, enfatiza que a "história somente é possível sobre o fundo de um vazio de história, em meio deste grande espaço de murmúrios, que o silêncio espreita, como sua vocação e sua verdade" ${ }^{70}$. Assim, a heterogênese do tempo histórico não

\footnotetext{
${ }^{66}$ Ibidem, p. 228 .

${ }^{67}$ FOUCAULT, M. Préface à Folie et Déraison. Dits et Écrits I, No 4, 1961, p.161.

${ }^{68}$ FOUCAULT, M. Histoire de la folie, p.143.

${ }^{69}$ FOUCAULT, M. Réponse a une question. Dits et Écrits $I, N^{\circ} 58,1968$, p.695.

${ }^{70}$ FOUCAULT, M. Préface à Folie et Déraison. Dits et Écrits $I, N^{\circ} 04,1961$, p.163. Não julgamos que este fundo de um vazio da história justifique uma interpretação completamente estocástica da história como assevera Veyne. Para este historiador, as práticas, as ações, as marcas mais rudimentares dadas ao pensamento humano são frutos dos "acasos da história", das "saliências e reentrâncias das práticas vizinhas e de suas transformações que fazem”, por exemplo, "com que a gramática política de uma época consista em amimar crianças ou, então, a administrar os fluxos: não é uma razão que edifica um sistema coerente" (cf. VEYNE, P. Como se escreve a história e Foucault revoluciona a história, p.253). É evidente, contudo, que não há uma razão que sustente uma coerência do acontecimento histórico, embora possamos conceber que haja um processo de racionalidade. Sustentar, contudo, que a história é forjada no acaso é ignorar, em Foucault, a perspectiva criativa que tenciona evidenciar certas formas de processos de saber-poder que investiram a sociedade ocidental, como afirma Lebrun - com quem concordamos inteiramente neste aspecto - "da escola à alcova, ele (Foucault) não fala apenas de práticas, mas de estratégias e dispositivos" (cf; LEBRUN, G. Passeios ao léu. Ensaios, p.82). Assim, faz sentido a crítica que o próprio Lebrun desfere: "É verdade que Veyne talvez force um pouco a barra para conseguir conjuntos estocásticos. É pouco dizer que os homens, para ele, não sabem a história que fazem: são a tal ponto prisioneiros do imediato (para falar delicadamente) que mal sabem que estão tomando a Bastilha. Antropologia tão pessimista, que choca a minha misantropia: depois disso, não é mais possível dividir os homens em imbecis e crápulas; não existem mais crápulas" (Opus cit, p.81). Levando isto em consideração, a nosso ver, o fundo de um vazio da história é toda dinâmica não unívoca que poderia instituir um sentido ou causa primeva do acontecimento, ou seja, relaciona-se à multiplicidade espacial que compunge práticas, instituições, noções,
} 
apenas desconfigura a monarquia de sentido, como também desvela o inacessível olvidado em toda "experiência nova" que, para além do campo de nossa experiência costumeira, prepara o "rosto do novo":

fazer a história da loucura significará portanto: fazer um estudo estrutural do conjunto histórico - noções, instituições, medidas jurídicas e policiais, conceitos científicos que mantém cativa uma loucura na qual o estado selvagem jamais pode ser restituído nele mesmo; mas na falta desta inacessível pureza primitiva, o estudo estrutural deve remontar na direção da decisão que liga e separa, por sua vez, razão e loucura; ela deve visar descobrir a troca perpétua, a obscura raiz comum, o afrontamento original que dá sentido à unidade como também a oposição de sentido e da insensatez ${ }^{71}$.

É preciso atentar para os seguintes aspectos. Colocando-se na dimensão declarada de um estudo estrutural do conjunto histórico, Foucault assume a perspectiva mutatis mutandis de revelar uma experiência que somente pode ser delineada pela relação plural de substratos condicionantes da singularidade. É por esta via, então, que demonstra que as diferentes compreensões, abordagens e tratamentos dispensados à loucura testemunhavam, mais do que a inquietude de um fenômeno, os sinais furiosos de transformação dependentes justamente do jogo dado entre noções, instituições, medidas jurídicas e policiais, conceitos científicos. A loucura transforma-se de acordo com as experiências homogêneas dos condicionantes histórico-culturais, logo ela não existe. É assim que "uma experiência singular aparece enfim. As linhas simples, um pouco heterogêneas, até então retraçadas, vêm tomar seu lugar exato; cada elemento pode gravitar segundo a sua lei justa"72. Para nós, há no contexto da História da loucura a concepção de um pólo ordenador de condições que não deixam de exercer as suas forças determinantes na constituição de uma experiência que, no ritmo de sua formação, exerce a sua força transformada no pensamento e nas ações humanas. Tanto é que foi a partir das condições históricas que arregimentaram uma nova percepção da loucura que permitiu, de maneira mais profunda e complexa, a objetivação do homem. Como argumenta Foucault,

a loucura é a forma a mais pura, a forma principal e primeira do movimento pelo qual a verdade do homem passa do lado do objeto e se torna acessível a uma percepção científica. O homem não se torna natureza (nature) para ele mesmo senão na medida em que ele é capaz de loucura. Esta, por sua vez, como passagem espontânea à objetividade, é momento constitutivo no vir-a-ser-objeto (devenir-objet) do homem ${ }^{73}$.

teorias - o que Foucault designará de estrutura - enfim, na direção de uma experiência nova. Entre as distâncias que existem entre cada uma delas, há um murmúrio que Foucault pretende narrar: o acontecimento histórico.

${ }^{71}$ Ibidem, p. 164 .

${ }^{72}$ FOUCAULT, M. Histoire de la folie, p.228.

${ }^{73}$ Ibidem, p.648. 
Portanto a história na dimensão de uma experiência fundamental aponta para a direção da "presença e trabalho de uma estrutura nova de experiência" ${ }^{74}$ que, do ponto de vista da subjetividade, coloca o sujeito na dependência de um conjunto sussurrante de condições das quais ele não pode escapar. Que escolhas, então, um sujeito poderia ter na constituição de sua subjetividade?

Esta indagação não deixa de subscrever um problema para o qual ainda estamos longe de vislumbrar resposta adequada, ainda mais porque em $O$ nascimento da clínica, texto de 1963, Foucault nos faz ver que a força das condições históricas com a qual nosso olhar apreende a visibilidade "do espaço, da linguagem e da morte"75 possui suas configurações surdas "em que a linguagem se apóia", dando azo a uma "relação de situação e de postura entre o que fala e aquilo de que se fala" ${ }^{, 76}$. Não é, então, sem razão a presença marcante, aliás recorrente, da busca pela experiência fundamental de um acontecimento oriundo da disjunção que ocorre no conjunto de determinados fatores condicionantes a orientar "as formas de visibilidade que mudaram" "77. Eis a questão: "mas que experiência fundamental pode instaurar essa evidente separação aquém de nossas certezas, lá onde nascem e se justificam?"78.

No caso da experiência da clínica, ou melhor, da anatomoclínica, um campo de visibilidade dotado de forças incontornáveis, por conseguinte, condicionantes, mais uma vez, arma-se como forma dinâmica de se ter "acesso ao indivíduo" numa "estrutura comum que recorta e articula o que se vê e o que se diz" ${ }^{\prime 79}$. Ao buscar pelo acontecimento que funde condições com visibilidade, Foucault nos conduz a enxergar, na persistência do tema das transformações históricas, os vetores de suporte responsáveis pela modificação das percepções de um acontecimento que "tem valor de emergência nas estruturas fundamentais" $" 80$. Isto representa pensar que a experiência fundamental da "medicina da percepção individual, da assistência familiar e dos cuidados em domicílio só podem encontrar apoio em uma estrutura coletivamente controlada e que recobre a totalidade do espaço social" ${ }^{\prime \prime}$, daí a implicância de se falar em suporte que, sob esta perspectiva, pode ser entendido como o lugar em que se forma um saber.

Ora, a lição dos hospitais, por assim dizer, traz à tona não somente um conjunto de circunstâncias a serem historicizadas dentro de vários cruzamentos sistemáticos, confusos e

\footnotetext{
${ }^{74}$ Ibidem, p.652.

${ }^{75}$ FOUCAULT, M. O nascimento da clínica, p.V.

${ }^{76}$ Ibidem, p.VII.

${ }^{77}$ Ibidem, p 215.

${ }^{78}$ Ibidem, p.VI.

${ }^{79}$ Ibidem, p.XVI.

${ }^{80}$ Ibidem, p.30.

${ }^{81}$ Ibidem, p. 21.
} 
disformes em séries estranhas umas às outras; porém vislumbra na relação do saber médico um fato individual, a sua centralidade mesma de não "mais ser apenas o corpus de técnicas da cura e do saber que elas requerem", mas por envolver, também, "um conhecimento do homem saudável, isto é, ao mesmo tempo, uma experiência do homem não doente e uma definição do homem-modelo" ${ }^{\prime 2}$. Em jogo, estão as novas exigências do olhar que se volta para o homem, para as disposições sub-reptícias nas quais forjarão sentido para que ele possa ocupá-las e preenchê-las. Circunscrita aos espectros históricos do meado final do século XVIII, a experiência da clínica soerguerá o seu campo prático à guisa da expansão do olhar: "ver, isolar traços, reconhecer os que são idênticos e os que são diferentes, reagrupá-los, classificálos por espécies ou famílias", enfim, com o intuito muito claro de constituir novos objetos sem ignorar a implicância real com os sujeitos que podem conhecer estes objetos: "novos objetos vão se dar ao saber médico, ao mesmo tempo e na medida em que o sujeito cognoscente se reorganiza, se modifica e se põe a funcionar de uma forma nova" ${ }^{\text {}}$. Como, entretanto, esta forma nova é possível? No caso, imaginamos que a reposta vai além de acalentar o contexto do saber médico e de toda a sua intervenção, já que tem o seu estofo na dinâmica da manifestação das coisas em sua verdade que, ao mesmo tempo, é forma de iniciação na verdade das coisas: "todo o visível é enunciado e que é inteiramente visível porque é integralmente enunciável" ${ }^{\prime 84}$.

\footnotetext{
${ }^{82}$ Ibidem, p. 37.

${ }^{83}$ Ibidem, p.96 e p.97, respectivamente.

${ }^{84}$ Ibidem, p.127. Não sem importância, neste cenário, encontra-se a interpretação que Deleuze dispensa ao pensamento de Foucault concernente a este ponto: "uma 'época' não preexiste aos enunciados que a exprimem, nem às visibilidades que a preenchem. Os dois aspectos são essenciais: de um lado, cada estrato, cada formação histórica implica uma repartição do visível e do enunciável que se faz sobre ela mesma; de outro lado, de um estrato ao outro, há variação da repartição, porque a visibilidade mesma muda de modo, e os enunciados mudam eles mesmos de regime". Com isto, alude ainda Deleuze, a História para Foucault "é esta determinação dos visíveis e dos enunciáveis em cada época, que ultrapassa os comportamentos e as mentalidades, as idéias, já que ela os torna possíveis". Se estamos citando este autor, é porque o julgamos importante na compreensão da conseqüência que esta dimensão implica na temática da subjetividade. Se no caso da História da loucura é possível ver o asilo surgir como lugar de visibilidade da loucura no mesmo tempo que a medicina formulava enunciados fundamentais sobre a "desrazão"; em O nascimento da clínica, vemos surgir um domínio anatomopatológico cujo lugar de visibilidade é o do domínio hospitalar ao mesmo tempo que se sustenta na Linguagem como forma de nomear o visível: "as coisas se oferecem a quem penetrou no mundo fechado das palavras; e se essas palavras se comunicam com as coisas, é porque elas obedecem a uma regra que é intrínseca à sua gramática" ( $O$ nascimento da clínica, p.126). Pois bem, com isto Focault está desvelando os lugares da visibilidade, que nunca possuem o mesmo ritmo, a mesma história, a mesma forma de serem enunciados, mas que, no entanto, trazem conseqüências inexoráveis para a posição do sujeito na história, como assevera Deleuze: "o sujeito que vê é ele mesmo um lugar na visibilidade, uma função derivada da visibilidade" (Cf. DELEUZE, G. Foucault, respectivamente: p.56 e p.64). De acordo com a nossa interpretação, na proporção da alternância de questões históricas estudadas por Foucault, portanto ascendidas à condição de visibilidade, esta acompanha a alternância das abordagens desferidas à temática do sujeito ocidental em sua constituição aberta, com o intuito de desdobrar cada implicância adstrita das funções atinentes a determinados jogos de subjetividade que nada mais seriam que formas visíveis de tratar e retratar o aspecto movediço, histórico e situacional atinentes ao sujeito. $\mathrm{O}$ sujeito é tema que se põe ao passo que, como sujeito, é erodido.
} 
Ocorre, contudo, ser nesta chave o alcance da visibilidade enunciativa a referência incontornável das transformações de um estatuto epistemológico. A implicância disto acaba sendo estrutural na medida em que condições de visibilidade atrelam-se às condições de enunciabilidade, e vice-versa, para pôr à mostra aquilo que depende de cada nível de "experiência e segundo toda sua espessura, para finalmente oferecer a uma percepção científica o que durante muito tempo tinha permanecido como invisível visível" ${ }^{\prime 85}$. Corrobora esta nossa interpretação o fato de Foucault afirmar que "a estrutura perceptiva e epistemológica que fundamenta a anatomia clínica, e toda a medicina que dela deriva, é a da invisibilidade visibilidade" ${ } 86$. No caso, trata-se da morte como elemento invisível que entra com força pungente nas cenas dos domínios do saber a partir do instante em que ela pode enunciar um "ponto de vista absoluto sobre a vida e abertura (em todos os sentidos da palavra, até no mais técnico) para sua verdade"; a partir de então, "não é porque caiu doente que o homem morre; é fundamentalmente porque pode morrer que o homem adoece" ${ }^{\wedge 7}$. O saber plasmado nesta visibilidade é, ao mesmo tempo, molde e matéria do artífice, isto é, dos impulsos anônimos em que a história está mergulhada. Notemos bem que, dentro deste esquadrinhamento, salta aos olhos a força constritora das condições históricas que escapam da vontade humana e que criam, obscuramente, os ângulos luminosos sob os quais homens e mulheres não podem se furtar ao confronto, pois isto diz respeito ao

tipo de objetos a conhecer [...], à posição que o sujeito deve ocupar para demarcá-lo, às medidas instrumentais que the permitem dele se apoderar, às modalidades de registro e memória que deve pôr em ação e às formas de conceituação que deve praticar e que o qualificam como sujeito de um conhecimento legítimo ${ }^{88}$.

Mas, daí, chama-nos a atenção o restante da argumentação de Foucault, que põe em evidência o vigor da disposição geral do saber como elemento constituinte da visibilidade: o que se modifica, fazendo surgir a medicina anatomoclínica, não é portanto, diz-nos,

a simples superfície de contato entre sujeito cognoscente e o objeto conhecido; é a disposição mais geral do saber que determina as posições recíprocas e o jogo mútuo daquele que deve conhecer e daquilo que é cognoscível. O acesso do olhar médico ao interior do corpo doente não é a continuação de um movimento de aproximação que teria se desenvolvido, mais ou menos regularmente, a partir do dia em que o olhar, que começava a ser científico, do primeiro médico se dirigiu, de longe, ao corpo do primeiro paciente; é o resultado de uma reformulação no nível do próprio saber e não no nível dos conhecimentos acumulados, afinados, aprofundados, ajustados ${ }^{89}$.

\footnotetext{
${ }^{85}$ Ibidem, p. 188.

${ }^{86}$ Ibidem, p. 183.

${ }^{87}$ Ibidem, p. 171.

${ }^{88}$ Ibidem, p. 151.

${ }^{89}$ Ibidem, p.151-152. Grifos nossos.
} 
Mas é possível apreender todo o processo da reformulação que ocorre no nível do saber? Cremos que não. A sua manifestação já é o acontecimento apreendido pela capacidade enunciativa, de cujas teias o homem é somente um fio tênue.

Ponto não despiciendo é o conjunto de conseqüências adstritas desta formulação. A nomeada figura do invisível visível, segundo Foucault, é grade imanente que "organiza a percepção anátomo-patológica" 90 , que, por seu turno, modifica o modo pelo qual o indivíduo passa a ser concebido: “o indivíduo não é a forma inicial e mais aguda em que a vida se apresenta”, ou seja, passa a ser percebido sob outro registro, mas justamente em decorrência da mutação silenciosa do saber, quer dizer, ele "só é dado ao saber ao término de longo movimento de espacialização, do qual os instrumentos decisivos foram um determinado uso da linguagem e uma conceituação da morte" ${ }^{91}$. Com isto, a ênfase da história recai, redobradamente, nas disposições fundamentais do saber, cujos "últimos anos do século XVIII", é importante frisar, permitiram à cultura européia e, por conseguinte, à cultura do Ocidente, construir

uma estrutura que ainda não foi desatada, aliás, começamos apenas a desembaraçar alguns de seus fios que nos são ainda tão desconhecidos que os tomamos de bom grado como maravilhosamente novos ou absolutamente arcaicos, enquanto, há dois séculos (não menos e entretanto não muito mais), constituíram a trama sombria, mas sólida, de nossa experiência ${ }^{92}$.

Nesta trama toda, nos deparamos com a concepção irrefutável por mais que Foucault se esforce em dizer o contrário tempos depois, de que a condição histórica de uma medicina que recebemos como positiva é fruto da constituição de condições históricas sob as quais pairam uma "estrutura em que se articulam o espaço, a linguagem e a morte" ${ }^{93}$. Se, portanto, há um jogo de subjetividade inerente à percepção da vida e da morte à guisa dos processos anatomoclínicos, é por causa de um tipo de estrutura ainda não desatada, que não deixa de ser responsável pelos traços que delimitam os espaços de nossas experiências. Com este cenário, fica evidente o quanto o sujeito é dependente das formas de visibilidades, condicionantes históricos independentes de sua razão, vontade e consciência. O sujeito acompanha o fato individual apreendido, cada vez mais historicamente, narrado na descrição de cada acontecimento que tem "valor de emergência nas estruturas fundamentais"94. Assim, quando

\footnotetext{
${ }^{90}$ Ibidem, p. 188.

${ }^{91}$ Ibidem, p.189.

${ }^{9}$ Ibidem, p. 219.

${ }^{93}$ Ibidem, p. 216.

${ }^{94}$ Ibidem, p.30.
} 
Foucault, no final de $O$ nascimento da clínica, afirma que "a possibilidade de o indivíduo ser ao mesmo tempo sujeito e objeto de seu próprio conhecimento implica que se inverta no saber o jogo da finitude" 95 , pensamos nós que já prenuncia o vigor que esta finitude, fios amarrados a esta anonímia estruturante, desempenhará no modo de ser do homem ocidental, fato explorado, assim, em As palavras e as coisas, obra de 1966.

Quais as implicâncias para a problemática do sujeito, contudo, se indagássemos pelas inversões inacabadas, ininterruptas e incontornáveis deste jogo no âmbito do saber? Encontraríamos, e de fato é o que ocorre, um número de cunhas históricas, bem precisas, pontuais, relacionadas a campos específicos e intransferíveis de noções, práticas, instituições que engendram condições que têm por tarefa cindir perpetuamente o sujeito, ou seja, de constituí-lo ao passo que tira dele o que ele tem, o que ele é. Focadas a partir de certas relações, as condições históricas configuram o sentido daquilo que se representa historicamente, do que se transforma. Assim, o sujeito é dado relativo, não extrapola e não pode estar livre das relações a circundá-lo. Mas de que modo isto se sustenta? A tentativa de dar visibilidade às orlas de "uma certa ordem muda"96, à qual o homem pertence recentemente - séculos XVIII e XIX -, notadamente no campo de alguns saberes cuja implicância maior recai sobre as Ciências Humanas, irá nos impelir, em As palavras e as coisas, para "os códigos fundamentais de uma cultura" que "fixam, logo de entrada, para cada homem, as ordens empíricas com as quais terá de lidar e nas quais se há de encontrar" ${ }^{\text {97. }}$

Nesta passagem, extremamente rica e difícil, devemos considerar o termo fixam no âmbito de sua contundência e conseqüência. O que está fixo é o incontornável de nosso pensamento, a vazão enunciativa que faz apenas existir a subsunção de um modo de ser afirmado na disposição e repartição de espaços do saber para eventuais conhecimentos e para possíveis manobras de um homem aquiescente às regras de certos domínios deste mesmo saber que, apesar de poder ignorá-las, não poderá se furtar de suas conseqüências. Os códigos que fixam não engessam, ao contrário, dão as condições de mobilidade, fornecem o campo de transigência, margeiam sem muita rigidez os limites de onde se pode ir e alcançar. A subjetividade é este fixo de linhas movediças dependente de uma ordem, definida ao mesmo tempo por

aquilo que se oferece nas coisas como sua lei interior, a rede secreta segundo a qual elas se olham de algum modo umas às outras e aquilo que só existe através do crivo de um olhar, de uma atenção, de uma linguagem; e é somente nas casas brancas desse

\footnotetext{
${ }^{95}$ Ibidem, p. 217.

${ }^{96}$ FOUCAULT, M. As palavras e as coisas, p.XVII.

${ }^{97}$ Ibidem, p.XVI.
} 
quadriculado que ela se manifesta em profundidade como já presente, esperando em silêncio o momento de ser enunciada ${ }^{98}$.

Dois aspectos devem ser destacados deste contexto. De um lado, as casas brancas do quadriculado representam os espaços de saber inconfundíveis em suas manifestações, que "obedecem a regras que não são todas dadas à consciência", fazendo reinar um tipo de "lei sem nome" 99 , na qual pulsam condições de possibilidades para um campo epistemológico aflorar certos conhecimentos, "encarados fora de qualquer critério referente a seu valor racional ou a suas formas objetivas"; na qual os conhecimentos "enraízam sua positividade e manifestam assim uma história que não é a de sua perfeição crescente" ${ }^{\text {100 }}$. Voltamos, assim, às indicações não teleológicas da história, mais do que isto, às contingências científicas, cuja história se antepõe aos fundamentos racionais de se encontrar sentido entre o que o homem faz e o que dele é feito. De outro lado, a espera silenciosa do momento que se anuncia, já que o homem enquanto tal está exposto ao acontecimento pari passu que o engendra e vice-versa, não implica em quietude inaudível ou que a força que o impele na direção do acontecimento seja o vigor não ruidoso de um espectro desfigurado. O silêncio é o traço mais marcante dos sinais de uma ruptura profunda que foge do controle de qualquer ente, pois está na confluência de uma emersão histórica "ao mesmo tempo como saber e como modo de ser da empiricidade" ${ }^{101}$; cum grano salis, é um tino ruidoso delator: muito pouco restou ao homem, ou quase nada, desde então. Mas por quê? Porque o trabalho empreendido em As palavras e as coisas é o paroxismo de uma abordagem que vai "tentar reencontrar na história da ciência, dos conhecimentos e do saber humano aquilo que seria como o inconsciente" ${ }^{102}$. A afirmação não é destituída de sérias conseqüências, menos pelo fato de abrigar a parte mais profunda do que não se vê, de operar os efeitos inversos e incompreensíveis numa primeira visão com relação à realidade; por abrigar as contradições necessárias, supressões, jogos enganosos, lapsos, superposições, enfim; mais pelo fato de poder ser entendido como uma certa estrutura formal: "o inconsciente possui ou, antes de que ele próprio, é uma certa estrutura formal"103.

\footnotetext{
${ }^{98}$ Ibidem, Id.

${ }^{99}$ FOUCAULT, M. Réponse à une question. Dits et Écrits I, No 58, 1968, p.695. Para o bem da argumentação e de seu enriquecimento, destacamos o contexto geral desta citação: "Todos estes aqui" - Foucault refere-se aos leitores d'Esprit que lhe dirigiram questões, como também se refere, cremos de um modo irônico, a uma série de interlocutores que, a seu modo, pretendia deixar claro a sua posição - "eu bem compreendo sua enfermidade. Eles tiveram, sem dúvida, um grande mal por reconhecer que sua história, sua economia, suas práticas sociais, a língua que eles falam, a mitologia de seus ancestrais, mesmo as fábulas que se contavam na infância obedecem a regras que não são todas dadas à sua consciência".

${ }^{100}$ FOUCAULT, M. As palavras e as coisas, p.XVIII

${ }^{101}$ Ibidem, p.302.

${ }^{102}$ FOUCAULT, M. Foucault répond à Sartre. Dits et écrits I, No 55, 1968, p.665.

${ }^{103}$ FOUCAULT, M. As palavras e as coisas, p.527.
} 
Dentro desta ordem de questões, podemos entender a dimensão a que se pretende chegar, desde já, como afirma Foucault:

a história da ciência, a história dos conhecimentos, não obedece simplesmente à lei geral do progresso da razão, não é a consciência humana, não é o progresso da razão humana que é um tipo detentor das leis de sua história. Há embaixo do que a ciência conhece dela mesma alguma coisa que ela não conhece; e sua história, seu vir-a-ser (devenir), seus episódios, seus acidentes obedecem a um certo número de leis e de determinações ${ }^{104}$.

Por esta afirmação, podemos perceber quão extensa é a dimensão dos domínios anônimos a ocupar a perspectiva desta história que se desenvolve sob o registro de uma arqueologia das ciências humanas. Condizente a isto, a estratégia aplicada na análise das condições de transformações de certos campos de saberes no umbral do período clássico em direção à modernidade, em nosso entendimento, servirá como catalisador e condutor da série de rompimentos que, por conseqüência desta postura teórica, serão inerentes à trajetória foucaultiana. Ora, ao relevar que não somente o substrato do pensamento humano tal como as práticas humanas estão adstritas às condições não totalizantes, unidimensionais e ausentes dos domínios racionais, mais do que expor os valores imaginários, o halo lírico por onde a verdade ocidental se embasou e trabalhou a perspectiva retórica que pudesse justificar ou fundar as questões de saber e ser, Foucault manifesta "o fato nu de que o homem achou-se vazio de história" 105 . É dizer que "o ser humano não tem mais história: ou antes, porque fala, trabalha e vive, acha-se ele, em seu ser próprio, todo imbricado em histórias que não lhe são nem subordinadas nem homogêneas" 106 , pois se dão na fragmentação do espaço e na visualização transitória de seus cacos. Com isto o homem não existe mais, ou seja, é um objeto possível, embora sempre imaginário, adstrito aos jogos contingentes de um saber que se constrói numa mutação sem fim. Não é sem sentido, sendo assim, que todo conhecimento positivo do homem passa a ser limitado "pela positividade histórica do sujeito que conhece" ${ }^{\prime 107}$. Tentar buscar as condições de suporte histórico que engendraram esta trama da possibilidade do que se conhece é, concomitantemente, deslindar um outro fio conectado ao lento, inacabado e distorcido processo da história da subjetividade no Ocidente. Como são tramas, uma vez que a positividade nunca é a mesma, o que temos são faces caóticas de uma temática refratária de incansável reposição sob as posições que o saber ocupará no recorte do conhecimento, não mais subsumido a uma pureza, essencialidade ou natureza. Entretanto, sob

\footnotetext{
${ }^{104}$ FOUCAULT, M. Foucault répond à Sartre. Dits et Écrits I, No 55, 1968, p.665.

${ }^{105}$ FOUCAULT, M. As palavras e as coisas, p.511.

${ }^{106}$ Ibidem, p.510.

107 Ibidem, p.516.
} 
esta medida que se impõe, "todo conhecimento passa a se enraizar numa vida, numa sociedade, numa linguagem que têm história"108. Por isto mesmo, nenhum tipo de abordagem a ser historicizada poderá mais ser a mesma. As implicâncias não são somente teóricas, contudo atingirão, estiolando, certas práticas outrora sustentadas por teorias. Mas o que está em xeque, afinal?

No mínimo quatro modificações, inflexões no pensamento eurocêntrico, por assim dizer, serão aduzidas a partir deste cenário. Longe, contudo, de caracterizarem uma ordem, assinalarão mais as frentes de referências com os quais o entendimento dado à subjetividade passa a ser testado, questionado e agitado, a ponto de transformar possíveis transparências em densas camadas turvas. De fato, à luz de Foucault, não há mais sentido em se pensar por intermédio de janelas teóricas com intuito de se alcançar um entendimento a respeito de qualquer realidade social ou individual. O saber é conjugado na dependência de um recorte tão transitório e fugaz que não pode apreender de modo sistemático e contínuo as modificações das quais ele mesmo faz parte, é conseqüência e forçosamente tem de falar.

Sendo assim, Foucault se posiciona a favor de que "é sempre sobre um fundo do já começado que o homem pode pensar o que para ele vale como origem”, em primeira mão, com o propósito de desmontar o sentido da origem das coisas ${ }^{109}$. Buscar o já começado não é pensar em vias de um determinismo, é, contudo, certificar-se de que o homem não pode mais do que as condições que coincidem com aquilo que ele é. Com isto, aliás, está montada a operação de dissolução de identidade do sujeito, ou seja, a expressão individual como determinante cognitiva de que o que pensa não corresponde àquilo que se é. $\mathrm{O}$ homem é assimétrico de si mesmo, pois "o originário no homem é aquilo que, desde o início, o articula com outra coisa que não ele próprio"; ademais, para não ficarmos limitados nesta proposição,

é aquilo que introduz na sua experiência conteúdos e formas mais antigas do que ele e que ele não domina; é aquilo que, ligando-o a cronologias múltiplas, entrecruzadas,

\footnotetext{
${ }^{108}$ Ibidem, Id.

109 Ibidem, p.456. A temática da origem não somente é retratada com vigor em As palavras e as coisas, notadamente no capítulo IX, intitulado O homem e seus duplos, no subitem O recuo e o retorno p.453-563, como também será prenúncio e alicerce fundamental na constituição de uma abordagem genealógica da história que, de maneira muito pontual, Foucault passará a perseguir - sem jamais abandonar -, fincado em sua interpretação da filosofia nietzschiana que ocorreu desde dois textos crucias. No primeiro, de 1971, Nietzsche, la généalogie, l'histoire, o filósofo francês demonstrará os equívocos e imprecisões de uma Ursprung na história, problematizando, em seu lugar, as dimensões de uma Entstehung (proveniência) e de uma Herkunft (emersão), a fim de buscar condições de uma história imarcescivelmente crítica. No segundo, de 1974, La vérité et les formes juridiques, ele busca também quebrar as dimensões de uma continuidade posta numa perspectiva histórica, fundada numa Ursprung, para ceder lugar a uma dimensão de pesquisa histórica que leve em consideração a origem como Erfindung, a invenção como força que o pensamento exerce e impõe ao forjar uma interpretação. Estas questões serão trabalhadas com minúcias no capítulo seguinte. Por ora, trouxemos estas indicações, pois, como temos sustentado, os fios característicos das noções e questões foucaultianas extrapolam o limite textual em que se encontram, caso que salta aos olhos no que diz respeito à genealogia.
} 
freqüentemente irredutíveis umas às outras, o dispersa através do tempo e o expõe em meio à duração das coisas ${ }^{110}$.

Então o homem não pode ser mais um valor imprescritível. Emerso de e pertencente a um campo de conhecimento específico como um objeto possível não mais de forma radical, é o ponto de origem de toda espécie de conhecimento, pois submete-se à duração das coisas. Objeto recente, o homem anuncia o que foi possível constituir a partir de sua visibilidade na mais nova dobra da história: as ciências humanas. Elas falam e depuram de tudo que o faz, doravante, afastar-se de toda e qualquer possibilidade essencial. Este cenário é chave primordial da falta de sentido que o humanismo passa a ter, pois cada vez mais distante de ser para si mesmo seu próprio sujeito, porque subsume-se ao pensamento e práticas das quais não controla e não determina in totum, descobre que se conjumina no interior de relações cujas regras cedem espaço para o seu contorno. "O homem pertence, portanto, ao campo dos conhecimentos como objeto possível e, de outra parte, ele estava colocado de modo radical ao ponto da origem de toda espécie de conhecimento"111.

Ora, em consonância a isto, uma segunda modificação ganhará vigor. Afastada a possibilidade do humanismo, uma vez que se põem a olho nu as condições históricas responsáveis pelo nascimento do homem, podemos, então, afirmar que toda uma reelaboração da teoria do sujeito decorrerá daí, pois vemos forjar uma forma totalmente diferente de se conceber o sujeito do conhecimento. Aliás, julgamos ser este viés o fulcro primevo por onde vai se firmando, cada vez mais, a problemática da subjetividade à Foucault. As palavras e as coisas levam às últimas conseqüências as análises de como certas modificações epistemológicas agiram, constituindo o que o homem pôde pensar por intermédio da linguagem, fazer por meio do trabalho e ser em detrimento do tratamento dispensado à vida. Donde determinados aspectos da subjetividade contemporânea passam a ser regidos e conferidos dentro do jogo dinâmico de finitudes das quais o homem não escapa; dentro de certas regras de um jogo "a partir das quais vemos nascer certas formas de subjetividade, certos domínios de objeto, certos tipos de saber" ${ }^{\prime 12}$. A sua linguagem lhe conferirá o limite de seu saber; o seu trabalho conferirá o limite de seu conforto, do que pode ter; e a sua vida lhe conferirá o limite necessário para ser consciente de seu fim próximo. Desta maneira, através da história, vemos a incidência das questões preponderantes que prenunciam a constituição de um sujeito que não é dado definitivamente - falar, trabalhar e viver, já são suficientemente

\footnotetext{
${ }^{110}$ Ibidem, p.457

${ }^{111}$ FOUCAULT, M. “Qui êtes-vous professeur Foucault?”. Dits et Écrits I, No 50, 1967, p.608.

${ }^{112}$ FOUCAULT, M. La vérité et les formes juridiques. Dits et Écrits I 1954-1975, No 139, 1974, p.1409.
} 
necessários para modificar, a cada instante, a constituição de cada um no interior da história. Assim, "um sujeito se constitui no interior mesmo da história, e é a cada instante fundado e refundado pela história"113 . Podemos admitir, portanto, sujeitos cuja incidência plural não mais consignará à temática a possibilidade de se pensar em um sujeito do conhecimento. $\mathrm{O}$ que se conhece é tão fluido e dependente da história quanto quem conhece.

Mas esta pluralidade afeta também os objetos a emergir do campo histórico. Tratados de forma arqueológica, privilegiando as "descontinuidades na epistémê da cultura ocidental" 114 , fica patente que a ordem, sobre cujo fundamento pensamos, somos e praticamos conhecimentos e exercemos ações, não tem o mesmo modo de ser. Em nosso entender, Foucault produz um efeito de distanciamento de uma das mais marcantes referências teóricas de seu tempo, o marxismo acadêmico, em sua expressão preferida, por julgar que a centralidade dispensada às condições econômicas de existência, por seu turno, consistindo no substrato em que se pudesse "encontrar na consciência dos homens o seu reflexo e expressão" 115 , não condizia com a multiplicidade de forças epistêmicas responsáveis pelo configuração do rosto do homem contemporâneo. É claro que não se trata de negar o pressuposto marxista, mas de implodi-lo como chave central da compreensão da constituição de nossa subjetividade, pois em sua forma mais comum,

ele supõe que o sujeito humano, sujeito de conhecimento, as próprias formas de conhecimento são de certo modo dados prévia e definitivamente, e que as condições econômicas, sociais e políticas da existência não fazem mais do que depositar-se ou imprimir-se neste sujeito definitivamente dado ${ }^{116}$.

Finalmente, uma outra vertente, além da do marxismo, será colocada vis-à-vis em decorrência da intersecção dos efeitos que estes elementos trazem no que diz respeito ao destino do homem na história. Se estamos diante de domínios autônomos do saber, espécie de “inconsciente do saber”, não podemos nos esquecer de que eles possuem suas próprias regras "como o inconsciente do indivíduo humano tem também suas regras e determinações"117. Nisto, julgamos encontrar se não a influência ao menos o fascínio que o estruturalismo exerce no pensamento de Foucault. Aliás, será por ele que não somente o ultrapassamento do

\footnotetext{
${ }^{113}$ Ibidem, p. 1408 .

${ }_{115}^{114}$ FOUCAULT, M. As palavras e as coisas, p.XIX.

${ }_{115}^{115}$ FOUCAULT, M. La vérité et les formes juridiques. Dits et Écrits I 1954-1975, № 139, p.1406.

116 Ibidem, Id. Isto não impede, contudo, de pensadores sérios buscar e até mesmo apontar aproximações marxistas no pensamento de Foucault, como Balibar: Foucault et Marx - l'enjeu du nominalisme. In. Michel Foucault philosophe. Rencontre internationale. Paris 9, 10, 11 janvier 1988. Paris: Seuil, p.54-76. Aliás, não podemos nos esquecer de que o próprio filósofo francês reconheceu no gênio de Marx a importante modificação que o seu pensamento operou no sentido de "uma nova possibilidade de interpretação" (Cf. Nietzsche, Freud, Marx. Dits et Écrts I, No 46, 1967, p.566).

${ }^{117}$ FOUCAULT, M. Foucault répond a Sartre. Dits et Écrits I, № 55, 1968, p.666.
} 
marxismo virá a ser firmado como também a via de contestação do desejo de liberdade, aquilatado pela força do existencialismo sartriano, dando ao homem condições de assegurar o seu destino pelo que pudesse fazer por intermédio de suas escolhas conscientes, que, então, ocorrerá. Pode ainda o homem ser o que ele projeta sob o influxo de um engajamento livre e consciente em sua existência? Dificilmente, sobretudo, se atentarmos para o elogio estruturalista que Foucault, sem ser encomiástico, deixa transparecer:

a partir do momento em que se percebeu que todo conhecimento humano, toda existência humana, toda vida humana, e talvez mesmo a hereditariedade biológica do homem, se encontra recolhida no interior de estruturas, isto é, no interior de um conjunto formal de elementos que obedecem relações que podem ser descritas, seja como for, o homem cessa, por assim dizer, de ser para si mesmo seu próprio sujeito, de ser ao mesmo tempo sujeito e objeto. Descobre-se que o que torna o homem possível é, no fundo, um conjunto de estruturas, estruturas que ele pode pensar e descrever, mas das quais ele não é o sujeito, ou a consciência soberana ${ }^{118}$.

É gritante o nível de comprometimento assumido aqui por Foucault à vista do estruturalismo. Não somente pela força universalizante conferida à dimensão do conhecimento e existência humana, mas por esquadrinhar, de fato, o modus operandi com o qual, segundo entendemos, vem, até então, trabalhando, isto é, pondo em evidência o interior de um conjunto formal de elementos que obedece relações que podem ser descritas. Mas aqui devemos nos valer de uma cautela indispensável à coerência problematizante de sua trajetória, para nos afastarmos de qualquer tentativa de associar os efeitos das questões dela advindas a um registro fixo do estruturalismo como grade teórico-metodológica. O que isto significa? Significa nos posicionarmos na direção da questão de fundo que traz à tona, ao cabo de todo este contexto pesquisas históricas cujo foco concernente à estrutura vêm se destacando ${ }^{119}$, o problema incontornável e inseparavelmente residual que está em xeque. E do que se trata, afinal?

\footnotetext{
${ }^{118}$ FOUCAULT, M. “Qui êtes-vous professeur Foucault?”. Dits et Écrits I, No 50, 1967, p.608.

${ }^{119}$ Uma indicação da dificuldade que se nos impõe pode ser vista da seguinte forma. Ao que nos parece, quando Veyne afirma que "a intuição inicial de Foucault não é a estrutura, nem o corte, nem o discurso: é a raridade", se chamamos a atenção para a questão da estrutura, a nosso ver, é como se Veyne ignorasse toda dificuldade e problemática que as obras dos anos sessenta do século passado eclodem, já que, como temos mostrado, não há como passarmos ao largo das indicações deliberadamente associadas a um plano estruturalista. É lógico que concordamos com Veyne na direção da raridade, no sentido que ela indica que os "fatos humanos são raros, não estão instalados na plenitude da razão, que há um vazio em torno deles para outros fatos que o nosso saber nem imagina". Mas daí poder afirmar que a estrutura não tange em momento algum a disposição do trabalho de Foucault já é algo com o qual não nos aproximamos. Não é à toa que um outro historiador, Revel, acaba sendo mais honesto quando enxerga nas pesquisas de Foucault, circunscritas à década de sessenta, apesar de toda implicância que isto traz, uma problemática cuja órbita leva em consideração todo fundo estruturalista em voga naquele contexto. Quer dizer, as preocupações de Foucault estão remetidas a um cuidado contemporâneo a ele, "ancorado no coração do projeto estruturalista dos anos sessenta e do início dos anos setenta" - Revel refere-se ao debate das referências teóricas da ciência História. E mais, chama-nos a atenção para o que não podemos ignorar, que o interesse da História, neste contexto, é "menos político que epistemológico: dar conta das
} 
É ao redor de todos os esforços possíveis e existentes, na via da prospecção histórica, que podemos conceber certos pontos de contatos com o estruturalismo, notadamente, a fim de nos levar a ver quão necessário é atacar a "quimera obnubilante", para nos valermos de um termo do filósofo francês, denominada homem, enquanto perspectiva da temática da soberania do sujeito. Como assim? Já deve estar claro o quanto pesa o próprio fato de se abordar a história pelo viés de "nosso inconsciente histórico, feito desses milhões, desses milhares de pequenos acontecimentos que, pouco a pouco, como gotas de chuva, esburacam nossos corpos, nossa maneira de pensar, e que depois o acaso faz [com] que um destes microacontecimentos deixem traços" ${ }^{120}$. Ora, eis aí a montagem que nunca será apreendida a não ser pelos seus cacos. O homem, agora no sentido expresso por Foucault, é mais um destes cacos formados no mosaico da história. E no jogo do vinco epistemológico, ele não existe senão por aquilo que dele se fala, não, contudo, a partir dele. Acuado cada vez mais em certas profundezas, a discursividade das ciências humanas se ocupa de algo muito diferente do próprio homem: "de sistemas, de estruturas, de combinações, de formas etc ${ }^{121}$ ". Sob a mesma regra, bem diante de nossos olhos, testemunhamos não somente a explosão do homem, mas o que concernia à natureza humana, ao sujeito do conhecimento, à liberdade, ao sentido, enfim, pressupostos marcantes da composição soberana do sujeito desfazem-se na mesma poeira com a qual o homem esteve imiscuído.

Sejamos francos, então. É possível Foucault descrever estruturas de saber sem ser estruturalista? Ora, a resposta, cremos nós, alumia o foco de interesse e, daí, as suas conseqüências. Não podemos negar o fato de que o estruturalismo, reconhecido pelo próprio pensador, teve o mérito de querer "fazer uma história, e uma história mais rigorosa e sistemática" e que há diferentes empreendimentos estruturalistas ${ }^{122}$, donde um modo refratário de análises históricas sempre pôde ser concedido. Mas julgamos que, na mesma direção que surge uma análise do conhecimento, via as questões do saber e da epistemologia das ciências humanas, sem partir do cogito, temos a presença de uma estrutura que é peculiar ao interesse e aos propósitos do autor de As palavras e as coisas. Em nosso juízo, então,

estruturas que portam a sociedade enquanto tais, refutando todo subjetivismo, aquele da consciência como aquele da ação. O tema da máquina (machine) - (NB: dispositivos acéfalos, reguladores e autoreguladores que podem ser encontrados nas instituições sociais, nos discursos, nos saberes etc) - teve então por corolário o desaparecimento (effacement) dos atores". (Cf. VEYNE, P. Como se escreve a história e Foucault revoluciona a história. Brasília: UNB, 1998. p.239; REVEL, J. Machines, stratégies, conduites: ce qu'entendent les historiens. In. Au risque de Foucault. Paris: Supplémentaires, 1997, p.116.)

${ }^{120}$ FOUCAULT, M. Le retour de Pierre Rivière. Dits et Écrits III, No 185, 1976, p.118.

${ }^{121}$ FOUCAULT, M. “Qui êtes-vous professeur Foucault?”. Dits et Écrits I, No 50, 1967, p.616.

122 FOUCUALT, M. Revenir à l'histoire. Dits et Écrits $I$ - 1954-1975, No 103, 1972, p.1136. "Há diferentes empreendimentos estruturalistas, quer sejam etnológicos, lingüísticos ou literários, e poder-se-ia dizer a mesma coisa a propósito da mitologia e a propósito das ciências humanas" (p.1138). 
Foucault enxerga, na vertente de análises estruturalistas, a possibilidade de se aprofundar na elaboração de uma história que afetará para sempre a feição do sujeito, pois sublinha que "não há uma natureza do conhecimento, uma essência do conhecimento, mas que o conhecimento é, cada vez, o resultado histórico e pontual de condições que não são da ordem do conhecimento" ${ }^{\prime 23}$. E como isto é feito? Por intermédio da elaboração de uma abordagem peculiar que visa colocar à mostra o que pode ser, então, entendido, no limite, por estruturalismo na ótica foucaultiana, preparando-nos o campo para, daí, irmos à direção de uma especificidade de trabalhos históricos que, ao seu modo, anunciarão a superação do estruturalismo $^{124}$. Sob isto, teremos uma grande reviravolta na história como espetáculo do mundo.

Pois bem. Quando, deste modo, podemos afirmar que uma análise estruturalista faria jus a Foucault e o que isto significaria? No entender de nosso autor, "uma análise é estrutural quando ela estuda um sistema transformável e as condições nas quais suas transformações se efetuaram" 125 . E aqui dois movimentos se dinamizam e, no ritmo em que se explicita o que vem a ser uma análise estruturalista, são traçadas as perspectivas seminais a deslocar o estruturalismo em sua densidade, ou seja, cremos que Foucault procura diluir não somente o seu comprometimento com a questão, mas também busca, pouco a pouco, instrumentalizar o que é de seu interesse ${ }^{126}$ : em marcha, um empreendimento de superação. E como isto se dá?

\footnotetext{
${ }^{123}$ FOUCAULT, M. La vérité et les formes juridiques. Dits et Écrits I-1954-1975, № 139, 1974, p.1419.

${ }^{124}$ Dosse é mais radical na direção do estruturalismo ao afirmar que Foucault "situa-se de corpo inteiro na galáxia estruturalista, ainda que se trate de um estruturalismo particular, pois o estruturalismo de Foucault não se baseia na existência de estruturas" (cf. DOSSE, F. Michel Foucault, estruturalismo e pós-estruturalismo. In. A história à prova do tempo. Da história em migalhas ao resgate do sentido. São Paulo: Unesp, 1999, p.205). De nossa parte, vemos dois problemas nesta posição. De um lado, julgamos muito temerário situar Foucault de "corpo inteiro" no estruturalismo. Já na década de 1960, o questionamento da aparição do sentido (Cf. "Qui êtesvous, professeur Foucault?". Dits et Écrits I, No 50, 1967, p.603 e Revenir à l'histoire. Dits et Écrits I - 19541975, No 103, 1972, p.1148); a ênfase na descontinuidade (Cf. As palavras e as coisas, p.68-80 e Revenir à l'histoire. Dits et Écrits I - 1954-1975, No 103, 1972, p.1147) e a reiteração das noções de mudança e acontecimento (Cf. Revenir à l'histoire. Dits et Écrits I - 1954-1975, No 103, 1972, p.1441), para nos atermos a alguns exemplos, não nos autorizam a sustentar tal interpretação, pois este conjunto de abordagens já se dispõe, notoriamente, contra o estruturalismo. De outro lado, se vimos que é recorrente a idéia de inconsciente histórico em Foucault, como afirmaríamos que isto não é um dado a indicar a existência de estruturas? O problema, a nosso ver, é que há uma contradição, ou melhor, uma ambivalência inerente ao pensamento de Foucault com respeito ao estruturalismo que não somos capazes de resolver, justamente porque a contradição é uma das formas de sua coerência. Se não é assim, como, então, resolver a seguinte afirmação: "O estruturalismo e a história contemporânea são instrumentos teóricos graças aos quais se pode, contra a velha idéia de continuidade, pensar realmente a descontinuidade dos acontecimentos e a transformação das sociedades" (Cf. Revenir à l'histoire. Dits et Écrits I - 1954-1975, № 103, 1972, p.1147). Ora, é preciso abrir mão da filosofia como profissão de fé e ver nela a possibilidade de um instrumento que ora se aplica em certo sentido, ora se aplica em outro. De nossa parte, diríamos que este é o aspecto mais pragmático da filosofia foucaultiana.

${ }^{125}$ FOUCAULT, M. Revenir à l'histoire. Dits et Écrits I - 1954-1975, No 103, 1972, p.1144.

${ }^{126}$ Aliás, nisto reside uma certa astúcia de Foucault. Reconhecidamente, a postura do pensador é de tomar conceitos, idéias, referências, pensadores, enfim, na perspectiva e em função de seu interesse. Isto fica claro, por exemplo, numa certa abordagem dispensada a Nietzsche: "[...] tomei este texto de Nietzsche em função de meus interesses, não para mostrar que era essa a concepção nietzschiana do conhecimento [...]", e generalizadamente
} 
Em primeiro lugar, é preciso ter em mente que desde A história da loucura até As palavras e as coisas são arregimentadas as provas de que há, numa cultura determinada, a correlação entre um domínio de saberes e formas de subjetividade. A exposição dos domínios estruturados, nesta direção, evidenciou a inevitável dinâmica existente entre as práticas humanas com seus conteúdos, ou seja, que suas emersões se relacionam a um tipo de sistema que ultrapassa a superfície do sentido das coisas. Assim, embora o estruturalismo, sobretudo no âmbito da linguagem, coloque o problema das condições formais da aparição do sentido, Foucault passa a privilegiar "a modificação ou interrupção do sentido, as condições nas quais o sentido desapareceu para fazer surgir outra coisa diferente"127. O que isto significa? Afastar-se do saber estruturado enquanto significante para tentar desatar as sujeições adstritas a esta dinâmica em que, sob o anonimato da história, repousariam latentemente certos sentidos na direção do homem. Desta forma, a noção de sistema passa a ser valorada como "um conjunto de relações que se mantém, se transformam, independentemente das coisas que elas religam" ${ }^{128}$. A ênfase recairá sobre as transformações. E ao fazer isto podemos prenunciar as armas com as quais a permanência do estruturalismo, até então, passa a ser tocada, já que a transformação, como veremos, implica na verticalização da descontinuidade, da mudança e do acontecimento. Enquanto isto não ocorre, na prática, o saber que paira sobre nossas cabeças como uma espécie de inclinação predominante, ao ser materializado pelas emersões históricas, margens tênues de rugas profundas, irá nos permitir vislumbrar um breve clarão, anunciando o instante fugidio sob o qual um há permitiu um determinado eu, nós: um pensamento anônimo, um saber sem sujeito, uma teoria sem identidade, pois se,

em todas as épocas, o modo cujo as pessoas refletem, escrevem, julgam, falam (até na rua, as conversas e as escritas mais quotidianas) e mesmo o modo pelo qual as pessoas provam as coisas, em que suas sensibilidades reagem, toda conduta, enfim, está comandada por uma estrutura, um sistema, que muda com as idades e as sociedades mas que está presente em todas as idades e em todas as sociedades ${ }^{129}$.

Impõe-nos, então, indagar como mudanças ocorrem em determinados sentidos e como é possível nos liberar do imperativo destes sentidos contidos em qualquer sistema. Com isto, será preciso focar as relações de conflito, vizinhança e mudança que estão em jogo para que se efetue uma análise das transformações a que somos suscetíveis.

ao sustentar: "eu não me interesso pelos autores mas pelo funcionamento dos enunciados; pouco importa quem o disse e quando foi dito" (cf. FOUCAULT, M. La vérité et les formes juridiques. Dits et Écrits I - 1954-1975, № 139, 1974, p.1418 e 1419). Se acima havíamos mencionado um aspecto pragmático de Foucault, não sem demora, conseguimos ver aqui um desdobramento latente, como o termo interesse testemunha.

${ }^{127}$ FOUCAULT, M. “Qui êtes-vous professeur Foucault?”. Dits et Écrits I, No 50, 1967, p.603.

${ }^{128}$ FOUCAULT, M. Entretien avec Madeleine Chapsal. Dits et Écrits I, No 37, 1966, p.514.

${ }^{129}$ Ibidem, p.515. 
A conseqüência disto, em segundo lugar, é que de um âmbito geral passamos a esquadrinhar níveis que portam, cada um deles, um tipo de saber particular; "ligando comportamentos, regras de condutas, leis, hábitos ou prescrições"; formando "configurações estáveis e suscetíveis de transformação" ${ }^{130}$. Com isto, o aspecto concreto das práticas sociais, antes negligenciadas, serão consideradas de maneira obrigatória, pois tais práticas "podem chegar a engendrar domínios de saber que não somente fazem aparecer novos objetos, novos conceitos, novas técnicas, mas também fazem nascer formas totalmente novas de sujeitos e sujeitos de conhecimento" ${ }^{\prime 131}$. Notemos que, desta maneira, deverá ser sublinhada a busca pelo jogo de relações complexas de causalidade responsáveis pela existência, doravante, de um nível particular que se espraia numa teia inapreensível, num sistema, portanto, que se configura para além de qualquer estrutura. Assim, pensamos nós, estão armadas as condições para se pensar numa história dos sistemas de pensamento, para longe do registro da estrutura, definida como "as formas pelas quais numa época dada os saberes se singularizam, tomando equilíbrio e entrando em comunicação" ${ }^{132}$. Não é à toa que nos depararemos, vis-à-vis, com a busca de novas condições empírico-metodológicas exigentes a um reajustamento de ordem: "a história do pensamento nos obriga a reinterrogar o conhecimento, suas condições e o estatuto do sujeito que conhece"133. Ao fazer isto, Foucault faz, na verdade, muito mais.

Colocar a questão desta maneira é vislumbrarmos, por decorrência, a transmutação irrevogável de um procedimento que engendrou, a partir da análise dos estratos da experiência, do anonimato e totalidade cultural, a força motriz de uma máquina, cujas operações condicionam fortemente os planos históricos de toda subjetividade. Eis aí um ponto nodal para o qual Foucault não é insensível. Entretanto nisto é preciso reconhecer a força de uma verdade: numa certa medida, o próprio pensador falava a partir de uma ordem discursiva, de uma ordem de saber, de dentro das suas condições que, associadas às suas pesquisas, a partir deste contexto, terão de ser re-embaralhadas, reorientadas, redescobertas, tramadas novamente, pois, se há uma força nas condições em que se efetuam transformações no sistema, elas não podem ser despojadas de conseqüências. O brilho das certezas, então, cede lugar à opacidade anunciadora de que todo estatuto privilegiado é consagrado à transitoriedade de tudo que pode ser apreendido pelo esforço da própria história.

É assim que podemos entender o contexto do surgimento de A arqueologia do saber, texto metodológico-chave nas transformações operadas na perspectiva da relação história e

\footnotetext{
${ }^{130}$ FOUCAULT, M. Titres et travaux. Dits et Écrits I, No 71,1969, p. 846.

${ }^{131}$ FOUCAULT, M. La vérité et les formes juridiques. Dits et Écrits I-1954-1975, № 139, 1974, p.1407.

${ }^{132}$ FOUCAULT, M. Titres et travaux. Dits et Écrits I, No 71, 1969, p.846.

${ }^{133}$ Ibidem, p.846.
} 
entendimento do sujeito-subjetividade, tendo lugar no ocaso da década de 1960 e aurora dos anos setenta; e, com ela, o disparo certeiro no coração dos historiadores que "identificam, descrevem e analisam estruturas, sem jamais se terem perguntado se não deixavam escapar a viva, frágil e fremente "história""134. De certo não podemos ignorar que isto cabe ao próprio Foucault. Tanto é que, em uma longa passagem desta mesma obra de 1969, temos a elaboração de uma contundente autocrítica - "diversas correções e críticas internas" responsável por uma nova via de perspectiva à compreensão da constituição de seus empreendimentos. Atentemo-nos às suas palavras, sem reservas:

de maneira geral, História da loucura dedicava uma parte bastante considerável, e aliás bem enigmática, ao que se designava como uma "experiência", mostrando assim o quanto permanecíamos próximos de admitir um sujeito anônimo e geral da história. Em $O$ nascimento da clínica, o recurso à análise estrutural, tentado várias vezes, ameaçava subtrair a especificidade do problema colocado e o nível característico da arqueologia. Enfim, em As palavras e as coisas, a ausência de baliza metodológica permitiu que se acreditasse em análises em termos de totalidade cultural. Entristeceme o fato de que eu não tenha sido capaz de evitar esses perigos: consolo-me dizendo que eles estavam inscritos na própria empresa, já que, para tomar suas medidas, ela mesma tinha de se livrar desses métodos diversos e dessas diversas formas de história $^{135}$.

E como se deslindará o esforço para se livrar desses métodos diversos e dessas diversas formas de história? A questão, ao que nos parece, resguarda o próprio significado que a arqueologia passará a ter.

Ciente da necessidade de levar às últimas conseqüências a perspectiva da descontinuidade, segundo a nossa interpretação, Foucault pende o vigor de seu pensamento para mudança e transformação. Isto implica forjar na composição do sentido de sistema as variações de séries de séries ${ }^{136}$ em que a prática serial de história passa a dar contornos a um espaço de dispersão. Significa pensar que a "história serial não se relaciona com objetos gerais e constituídos por antecipação, como o feudalismo ou o desenvolvimento industrial”, o que não nos impede de mencionarmos o sujeito também. Mas não é só, "a história serial define seu objeto a partir de um conjunto de documentos que ela dispõe "137. Ainda que tenhamos aqui o prenúncio da transformação tanto da definição e do papel que o objeto ocupará na história serial, presságio irreversível para uma história crítica, também está pavimentada a via intransigente, embora por reformulações, com a qual não se prescindirá de questionar a origem dos sentidos e das coisas, a centralidade do sujeito, de impor ao homem

\footnotetext{
${ }^{134}$ FOUCAULT, M. A arqueologia do saber, p.13.

135 Ibidem, p. 19.

${ }^{136}$ Cf. FOUCAULT, M. Arqueologia do saber, p.12.

${ }^{137}$ FOUCAULT, M. Revenir à l'histoire. Dits et Écrits I-1954-1975, No 103, 1972, p.1144.
} 
— no viés do humanismo - uma indagação contunde, pois afinal, tudo isto não pode existir antes de a história constituir o documento. Mas isso é justamente o "estabelecimento de um certo números de relações" 138 contigenciadas num enunciado ou forma enunciativa. A sua emergência se deve a uma série singular de acontecimento apreendido na homogênese de um objeto determinado e de uma época determinada que, sendo assim, modifica-se completamente na proporção que se desloca das condições históricas que permitiram a sua emersão. É o mesmo que dizer, portanto, que, para o fundo de toda homogênese, implicará uma análise heterogênea, pois, na medida de sua consecução, o acontecimento passa a ser tratado como individualidade; particularidade irreversível.

Neste sentido, duas conseqüências de grande porte se desdobram, ambas no horizonte de distinguir Foucault do campo estruturalista de análise, como de fato ele mesmo o faz. Em primeiro lugar, por não possuir correlatos, o "enunciado existe fora de qualquer possibilidade de reaparecimento; e a relação que mantém com o que enuncia não é idêntica a um conjunto

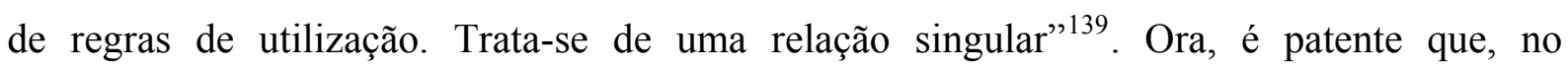
estruturalismo, o sentido se faz no âmbito de sua correlação com determinada estrutura, permitindo-nos vislumbrar a continuidade existente entre projeção de sentido e seu efeito. Mas, na ótica que se impõe, o arquivo, por representar o conjunto de discursos efetivamente pronunciados numa época, continuando a existir através da história, só pode ser analisado e existir sob a compreensão dos enunciados, implicando regras, práticas - relações discursivas e não discursivas -, e suas condições de emergência e funcionamento são apreendidos na camada de acontecimentos que se multiplicam.

Com isto, em segundo lugar, a história não tem mais a mesma duração, pois, para cada enunciado, há um tipo diferente de duração de significado, sentido da regra e do discurso e da prática. Há uma operação de explosão de perspectivas a fatiar a já velha acepção de que o saber emanava de uma atmosfera acéfala, anônima, sub-reptícia; o saber passará para uma outra grade de análise, uma vez que é devedor da "operação deliberada do historiador" "140, responsável pela descrição do "jogo de interrupções profundas"141 a marcar para sempre o nosso rosto e as nossas paisagens. Diante de todo este quadro, a descontinuidade assinala não somente os tipos de durações diferentes, doravante, exigentes à história, mas também os tipos diferentes dos fenômenos humanos consignados à história de fundo movediço fragmentado: não há mais o imperialismo do repetitivo, nem do oculto-anônimo. Desembaraçados do

\footnotetext{
${ }^{138}$ Ibidem, Id.

${ }^{139}$ FOUCAULT, M. A arqueologia do saber, p.101-102.

${ }^{140}$ Ibidem, p.10.

${ }^{141}$ Ibidem, p 04.
} 
mesmo tempo, podemos vislumbrar as condições de desamarras, outrora impossível, das condições sufocantes do saber; pois, sob um tempo sincopado, o acontecimento projeta-se de modo múltiplo. Com a mesma força que determinados saberes preparam as condições para o surgimento de um tipo de homem, agora, este mesmo homem poderá alcançar outras condições, já que se põe ao lado das miríades de acontecimentos que são liberados na proporção de seu anúncio. O homem é uma epifania inacabada e aberta; efeito enunciativo, isto é, acontecimento adstrito às regras e leis que tornaram possíveis a "existência daqueles enunciados" e não outros em seu lugar; devedor das "condições de sua emergência singular"; de sua "correlação com outros acontecimentos anteriores e simultâneos, discursivos ou não" ${ }^{142}$. Estamos, assim, caminhando-nos para longe da grade formal e estrita que havia nos estruturado:

à raiz do tempo da história, não há qualquer coisa como uma evolução biológica que carregaria todos os fenômenos e todos os acontecimentos; há, de fato, durações múltiplas, e cada uma destas durações é portadora de um certo tipo de acontecimento. É preciso multiplicar os tipos de acontecimento como se multiplica os tipos de duração $^{143}$.

E de que maneira isto tem o seu lugar e o que advém por conseqüência? Ora, o acontecimento não é mais resguardado sob o influxo daquela "certa ordem muda" que espera a confluência das condições e transformações para emergir com força inevitável. É óbvio que o descontrole da história é evidente, pois há muito se ultrapassou a Providência, o fluxo paciente e inevitável da Síntese e o domínio completo do Homem com a sua consciência sobre os fatos. Entretanto, condicionado à enunciação, o acontecimento tem a sua força consignada à fragilidade de seu anúncio. É por este motivo que "a enunciação é um acontecimento" e, enquanto tal, "não se repete", aliás, "tem uma singularidade situada e datada que não se pode

\footnotetext{
${ }^{142}$ FOUCAULT, M. Reponse à une question. Dits et Écrits I, No 58,1968 p.681

${ }^{143}$ FOUCAULT, M. Revenir à l'histoire. Dits et Écrits I - 1954-1975, № 103, 1972, p.1147-48. Neste sentido, já é gritante a diferença que podemos constatar no estatuto que o estruturalismo ocupa no empreendimento de Foucault e mesmo o sentido que passa a ter. É importante que o leitor compare esta perspectiva com aquela colocada acima, por exemplo, a partir da nota 118, na qual mencionávamos o gritante nível de comprometimento assumido por Foucault à vista do estruturalismo. Notemos bem a questão. De um lado, não podemos ignorar o quanto o foco estruturalista esteve presente nos ciclos das obras da década de 1960 e as conseqüências disto. Por evidência, não podemos assumir uma postura interpretativa, como se isto não tivesse propósito ou significado na trama do deslindamento das questões que são arroladas. Por exemplo, a nós nos parece que, quando Revel afirma que "é precisamente o arquivo, no sentido próximo da arqueologia, que permite Foucault de se distinguir do estruturalismo, uma vez que se trata de trabalhar com os discursos considerados como acontecimentos e não como sistema de linguagem geral", apesar de concordarmos com a assertiva, julgamos que ela se torna categórica no sentido de tentar se desviar, justamente, das dificuldades que a presença do estruturalismo assume neste período do pensamento de Foucault. Por outro lado, avançamos em nossa própria interpretação, já que não é somente o enunciado como argumento que desloca Foucault desta dimensão, mas, ponto não desprezível, também é a descontinuidade, como estamos sustentando acima. (cf. REVEL, J. Michel Foucault: expériences de la pensée. Paris: Bordas, 2005. p.63-64.)
} 
reduzir" ${ }^{\prime 44}$. Portadora da gama inesgotável do enunciado, firma-se por intermédio da asserção de que "um enunciado é sempre um acontecimento que nem a língua nem o sentido podem fazer esgotar" ${ }^{145}$. É forçoso enxergamos aí a multiplicação dos acontecimentos, pois, mesmo que haja um mesmo tipo de enunciado, uma materialidade repetível e estabilizada numa ordem qualquer, a enunciação nunca será a mesma; obriga e forja, a cada instante que vem a lume, um acontecimento novel. Sob este cenário, notemos como, então, o tratamento dado ao saber nos compele para a diversidade possível de nos relacionarmos com a multitude indefinida de pontos de ligações que serão os campos de constituições históricas dadas pelo vigor de cada enunciação a endossar o acontecimento. É assim, então, que ainda ao falar em épistémè, Foucault deixará bem claro o quanto se pensar em uma figura imóvel é um equívoco. E mais, sublinhará o fato de que a sua descrição "abre um campo inesgotável" que "nunca pode ser fechado" e "não tem por finalidade reconstituir o sistema de postulados a que obedecem todos os conhecimentos de uma época, mas sim percorrer um campo indefinido de relações" ${ }^{\prime 46}$. Ao que nos parece, a partir disto, podemos entender melhor a razão pela qual o homem se desvanece e, com ele, toda a forja fixa que não esteja colocada sob a dinâmica das relações. Quer dizer, se a enunciação muda a forma do acontecimento vir à tona, Foucault tem toda razão ao dizer que "se estas disposições", isto é, as condições epistêmicas que ensejaram determinados sentidos para a constituição da subjetividade ocidental, fixando-lhe chão, "viessem a desaparecer tal como apareceram, se, por algum acontecimento quando muito pressentir a possibilidade, mas de que no momento não conhecemos ainda nem a forma nem a promessa, se desvanecessem [...] então se pode apostar que o homem se desvaneceria, como, na orla do mar, um rosto de areia" ${ }^{147}$. Pois bem. Em nossa interpretação, A arqueologia do saber nos permitiu enxergar este acontecimento, doravante, colidido com a enunciação. Sob a força deste cenário, portanto, o homem, de fato, se desvaneceu e as implicâncias vão ao longe para a constituição de sua subjetividade, agora, consignada à inevitabilidade de cada acontecimento cujo frêmito não cessa de se interpor entre a face que se apaga e a ação que a redesenha. Mas o que seria, então, o acontecimento?

A nosso ver, existe uma série de confluência de questões que, antes mesmo de nos permitir apreender o alcance deste importante ponto, coloca em relevo a decisiva característica que a história assumirá a partir de A arqueologia do saber, marcando-a

\footnotetext{
${ }^{144}$ FOUCAULT, M. A arqueologia do saber, p.116.

${ }^{145}$ FOUCAULT, M. Sur l'archéologie des sciences. Réponse au Cercle d'épistémologie. Dits et Écrits I, № 59 , 1968, p.707.

${ }^{146}$ FOUCAULT, M. A arqueologia do saber, p.216.

${ }^{147}$ FOUCAULT, M. As palavras e as coisas, p.536. Chamamos a atenção para o nosso grifo.
} 
profundamente e também caracterizando-a em certo sentido. Diagnóstico, atualidade e presente não se distanciarão mais do importante sentido do acontecimento, auxiliando na constituição do que podemos assinalar como histoire de la pensée. Senão vejamos.

Concernente ao diagnóstico, é clara a postura de Foucault no final da obra acima citada a fim de reenfatizar o alcance cujo termo permitirá conferir um novo valor à história e, subseqüentemente, às disjunções de terrenos a pulverizar qualquer intenção de univocidade ao sujeito e, por incidência, à subjetividade. Assim, conduzindo-nos para percebermos os efeitos de descentração conseqüentes da formulação que a enunciação produz na história, concomitantemente, podemos ver sublinhado o quanto se evita pensar na determinação de um lugar de onde se fala, a rejeição de um "solo em que se poderia apoiar"148. Ao indicar isto, presenciamos a delineação da história como diagnóstico. Por quê? Porque, diz-nos o autor de A arqueologia do saber,

ao invés de percorrer o campo dos discursos para refazer, por sua conta, as totalizações suspensas, ao invés de procurar, no que foi dito, o outro discurso oculto, que permanece o mesmo (ao invés, portanto, de ele fazer, sem interrupção, de alegoria e de tautologia), opera sem cessar as diferenciações: é diagnóstico. ${ }^{149}$

Interpretamos que operar as diferenciações não somente indica o estatuto do diagnóstico como também põe à prova a importante charnière que ele desempenhará no sentido de dirimir a falsa impressão de que é tão evidente e inevitável as condições que nos trouxeram até aqui. Quer dizer, as margens rígidas dos contornos históricos que praticamente condicionavam a subjetividade a emanar dos empreendimentos históricos da década de 1960, doravante, sob esta nova sigla, irão nos auxiliar a enxergar, como desdobramento de potência visual, que tudo o que repetimos e continuamos a repetir, chancelando, portanto, registro dos acontecimentos, está atravessado por um saber que, ao ser diagnosticado, pode nos liberar de todo acontecimento como repetição de nossa atualidade. Diagnosticar é apreender o espectro múltiplo de saberes sob os sinais dos quais nós temos condições de ser e estar. É poder "mostrar que o que é nem sempre foi", isto é, que estamos "sempre na confluência de reencontros, acasos, ao fio de uma história frágil, precária, em que são formadas as coisas que nos dão a impressão de serem as mais evidentes" ${ }^{150}$. Nisto, vislumbramos o intento primordial

\footnotetext{
${ }^{148}$ FOUCAULT, M. A arqueologia do saber, p.233.

${ }^{149}$ Ibidem, Id. Grifos originais.

${ }^{150}$ FOUCAULT, M. Structuralisme et postsctructuralisme. Dits et Écrits IV. No 330,1983 , p.449. Sob esse ângulo, apesar do tratamento lúcido e reiterado que Veyne dará à história, não podemos concordar com a sua postura ao sustentar que "Foucault é o historiador acabado, o remate da história". Aliás, no máximo, Foucault atribuíra à sua própria obra uma "função de diagnóstico", não se lançando às pretensões de acabamento. É importante notar, ainda, que as histórias realizadas por Foucault funcionam como flashs a iluminar determinadas
} 
do filósofo em denunciar as falsas evidências que teceram, fio após fio, o cenário constituinte do pensamento ocidental em cujo campo contextual discursos e práticas se despontaram como necessidade fundamental ao homem, como se seu horizonte não pudesse ser diferente do que foi e tem sido. O diagnóstico é o prenúncio de uma empreitada incansável: a “impiedosa destruição que efetua de todos os 'falsos objetos' sócio-culturais que o historiador das idéias ou das mentalidades é tentado a tomar como pontos de referência"151.

Desta maneira, então, o diagnóstico está igualmente alocado no acontecimento em vias de surpreender, deslocar, provocar, ainda que desterritorializando, o que ficou impregnado do cintilar do passado, mas que ainda marca o presente. E, desta forma, ao ser plasmado, o acontecimento torna-se espécie de visibilidade capaz de desinibir a forma latente e secreta de toda regularidade para provar que "falar é fazer alguma coisa"152. Falar, símbolo da anunciação imarcescível interposta no processo incipiente de dessujeição que começa a ganhar notoriedade quando a abrangência dos fatos, dos pensamentos, das ações, das coisas e dos homens são dependentes do acontecimento enquanto forma histórica; não sem sentido, será exigida do acontecimento uma imbricação forçosa com a atualidade e o presente. Mas por quais razões?

Se a força da história como diagnóstico torna-se ferramenta beligerante com o intuito de penetrar na espessura de nossa cultura, forçando o acontecimento, isto somente será possível na proporção de sua especificidade. Então, em primeira mão, é preciso notar que o acontecimento incontornavelmente produz a erupção do novo e com isto o reforço inacabado de toda descontinuidade, já que não é "um segmento do tempo"; nem a identidade de uma história; é o indicador de que existe "várias histórias, vários tempos, várias durações, várias velocidades (vitesses), que se cruzam e formam precisamente o acontecimento" ${ }^{153}$. Ora, com isto nos afastamos da perspectiva de coerência histórica ou de qualquer traço antropológico imediato ou, ainda, de qualquer constante que pudesse nos impor um mesmo modo de percepção e apreensão histórica igualmente a todos. O acontecimento é singularidade que, vista sob o ângulo da particularidade, remove os canais contínuos por onde estávamos condenados a ver a necessidade das coisas. Mostra ainda "que não era 'tão necessário assim"” e nem evidente: "não era tão evidente que os loucos fossem reconhecidos como doentes mentais; não era tão evidente que a única coisa a fazer com um delinqüente fosse interná-lo;

áreas do pensamento ocidental, mas que não arrematam a sua história. (Cf. VEYNE, P. Como se escreve a história e Foucault revoluciona a história. Brasília, Editora UNB, 1998, p.239).

${ }^{151}$ LEBRUN, G. Passeios ao léu. Ensaios. São Paulo, Brasiliense, 1983, p.78.

${ }^{152}$ FOUCAULT, M. A arqueologia do saber, p. 237.

${ }^{153}$ FOUCAULT, M. La scène de la philosophie. Dits et Écrits III, № 234, 1978, p.581. 
não era tão evidente que as causas da doença devessem ser buscadas no exame individual do corpo etc" $" 154$. E, ao proceder desta maneira, uma conseqüência inevitável se impõe a nós mesmos: na constituição da subjetividade de cada um, repousam aquelas velhas certezas e evidências sobre as quais "se apóiam nosso saber, nossos consentimentos, nossas práticas"155. Mas encarar tudo isto sob a dimensão de que o que somos é um encontro passageiro e transmutável de pontos cujas condições podemos apreender, portanto uma ruptura com toda certeza se produzirá e a subjetividade não cessa de ser um jogo a acontecer sem acabamentos prévios ou futuros em todas as linhas de nossa constituição. Daí, a singularidade do que somos será a explosão incorrigível dos substratos condicionantes do sujeito. Se a história está inexoravelmente posta na nomenclatura do acontecimento, notemos bem, não há mais “encarnação de uma essência nem a individualização de uma espécie”; ela está calcada sobre todo um conjunto de singularidades como acontecimento, donde questionado o acontecimento, questionada a singularidade: "singularidade como maldade no mundo moderno ocidental, singularidade absoluta como sexualidade, singularidade absoluta como sistema jurídico-moral de nossa punição" ${ }^{156}$, por exemplo.

Com isto, em segundo lugar, o acontecimento é responsável por instituir um conjunto de heterogeneidade de expansão incontida, pois opera "segundo os processos múltiplos que o constituem" ${ }^{157}$. Isto implica em dois fatores: estar atento à ampla e complexa formação de um processo histórico que não pode ser saturado de uma só vez e que será forçosamente inacabado, portanto sujeito à transformação; também implica num polimorfismo de relações que, ao serem descritas, desfazem domínios de referências unívocos e ampliam as mutações em razão de suas relações, sobretudo com "jogos de força e estratégias, que, em um dado momento, formaram o que, em seguida, funcionará como evidência, universalidade, necessidade" ${ }^{\prime 158}$. Contudo não podemos perder de vista que a história événementiel põe à

\footnotetext{
${ }^{154}$ FOUCAULT, M. Table ronde du 20 mai 1978. Dits et Écrits IV, No 278, 1980, p.23.

${ }^{155}$ Ibidem, Id.

${ }^{156}$ FOUCAULT, M. What is critique? In. SCHMIDT, J (Org.) What is Enlightenment? Eighteenth-Century answers and Twentieth-Century Questions. California: University of California Press, 1997, p.395. Conferência inédita realizada por Foucault em 1978, intitulada Qu'est-ce que la critique. Critique et Aufklärung vertida para o inglês por Kevin Paul Geiman: What is critique? Este texto não foi publicado nos Dits et Écrits, cuja versão francesa encontra-se no Bulletin da la Société française de Philosophie 84 (1990): 35-63, atualmente esgotado.

${ }^{157}$ FOUCAULT, M. Table ronde du 20 mai 1978. Dits et Écrits $I V, \mathrm{~N}^{\circ} 278$, p.24. E aqui vale a pena mencionarmos, de uma vez por todas, o quanto, então, o estruturalismo passa a encontrar a sua superação. "Admite-se que o estruturalismo", diz-nos Foucault, "foi o esforço o mais sistemático para se afastar não somente da etnologia, mas de toda série de outras ciências, e mesmo, no limite da história, do conceito de acontecimento. Eu não vejo talvez ninguém mais antiestruturalista do que eu. O mais importante é não fazer para o acontecimento o que se fez para a estrutura". (Cf. FOUCAULT, M. Entretien avec Michel Foucault. Dits et Écrits III, N 192,1977, p.145).

${ }^{158}$ Ibidem, p.23.
} 
mostra justamente acontecimentos que possuem disposições e tipos diferentes de amplitude cronológica e capacidade de produzir efeitos, mas que, ao fazer isto, de uma forma ou de outra, não prescinde da palavra. "Mas a palavra?” - argumentamos com o próprio Foucault é o "delicado acontecimento que se produziu em um ponto do tempo e não em outro"159. O acontecimento já seria, então, fruto do corte exercido pela palavra, ou melhor, a palavra é um acontecimento, pois tem lugar e força como surgimento de novas situações observáveis ${ }^{160}$.

Sob estas condições, é inevitável a força motriz atuante que o acontecimento pode aplicar sobre a nossa atualidade, pois se põe em correlação com um "pensamento móvel" cujo objetivo é o de indagar incansavelmente: “o que somos nós neste instante? Qual é este momento tão frágil em que nós podemos desatar a nossa identidade?"161. Mobilidade geral: novo estatuto para o presente, para o atual. Por quê? Pelo que decorre da própria história como diagnóstico: rupturas, julgamento, transformação do espaço infinito em história da cena $^{162}$ e, talvez o mais importante, que por ele o acontecimento é tangível e palpável a qualquer um. A mobilidade não apenas é capaz de lutar contra os pontos fixos como também nos permite ir além da condição atual de pensamento em que são contínuas a sensação e a condição cujos focos reforçam experiências que afirmam não podermos mais fazer nada ${ }^{163}$.

\footnotetext{
${ }^{159}$ FOUCAULT, M. Les mots qui saignent. Dits et Écrits I, No 27, 1964, p.424.

160 Farge trata da perspectiva da palavra enquanto acontecimento. Julgamos sua análise muito elucidativa, principalmente no que se refere à necessidade da palavra desenhar, nem que seja a golpes, "as cenas que são de fato acontecimentos". E aqui, pensamos na importante direção que não devemos deixar de destacar na obra de Foucault: "se se considera", como diz a própria Farge, "certas formas de sofrimento e seus modos de expressão como acontecimentos históricos, pode-se refletir sobre suas conseqüências". Desnecessário dizer o quanto disto subjaz ao pensamento foucaultiano. (Cf. FARGE, A. Des lieux pour les histoires. Paris: Seuil, 1997, p.23. Ver também p.89 para os termos no corpo do texto). Como se isto não fosse suficiente, cremos que, com o acontecimento, Foucault nos faz posicionar, senão ao menos rever, as nossas posições atuais, no sentido, como bem disse Deleuze, de que "um acontecimento microscópico estremece o equilíbrio do poder local" (Cf. DELEUZE, G. Mil platôs: capitalismo e esquizofrenia. V. 1. São Paulo: Editora 34, 2004, p.25)

${ }^{161}$ FOUCAULT, M. Pour une morale de l'inconfort. Dits et Écrits III, No 266, 1979, p.783.

162 A expressão em itálico é de: FOUCAULT, M. La scène de la philosophie. Dits et Écrits III, No 234, 1978, p.574.

${ }^{163}$ Concernente a este tópico, nos posicionamos ao lado de Ewald cuja contribuição é irreparável e auxilia-nos no combate de uma certa interpretação que sustenta um niilismo de Foucault, senão vejamos. Para Ewald, "somos profundamente marcados - é uma dificuldade filosófica atual fundamental - por esta idéia que nada mais pode acontecer. A idéia de que não se pode mais produzir acontecimento, que as coisas e o tempo são constituídos de tal maneira, independentemente do que fazemos, isto não pode mais ser um acontecimento porque, de qualquer modo, o tempo, as significações estão imobilizadas” (EWALD, F. Foucault et l'actualité. In. Au risque de Foucault. Paris: Centre George Pompidou, 1997, p.207-208). Ora, mas do ponto de vista do acontecimento e de sua marcante presença, fica claro que esta percepção comum é dissolvida, num processo de superação, a fim de permitir a postura beligerante que não mais desprenderá do pensamento foucaultiano, notadamente, pelo fato de o acontecimento se interpor no caminho de toda norma e normatização, como também normalização. Se pelo diagnóstico somos capazes de tomar conhecimento de quais os acontecimentos que nos dominam, por ele, também somos capazes de nos tornar acontecimento - que é a capacidade de produzir o que somos. O acontecimento seria semelhante a uma maquinaria necessária para produzir o ser. Como vemos, nada mais falso do que se pensar numa perspectiva histórica niilista. Assim, precisamos ver com muito cuidado a interpretação de Glücksmann referente ao Le nihilisme de Michel Foucault. Concordaríamos que, de fato, há um relativismo de valor em Foucault e a recusa de um valor supremo, certo, Deus e o Homem foram sepultados
} 
De modo direto, afirmar a atualidade é, ao mesmo tempo, indagá-la e, ao ser feito isto, buscarmos a compreensão de que vivemos num campo de experiências possíveis: "O que é a nossa atualidade? Qual é o campo atual das experiências possíveis?"164. Pensamos ser esta problemática a chave de compreensão para o papel que cumprirá a história do pensamento, pois, por seu intermédio, o atual não se limita ao imediatismo do que somos, mesmo porque tem a sua base na própria função desempenhada pelo arquivo na constituição de uma história sustentada arqueologicamente. Assim, essencialmente interrogadora, a atualidade pode menos assumir o seu papel direto com o que somos e mais com aquilo que não somos, ou seja, com o nosso vir-a-ser-outro. É neste registro que concebemos a farta argumentação de Foucault:

a análise do arquivo comporta, pois, uma região privilegiada: ao mesmo tempo próxima de nós, mas diferente de nossa atualidade, trata-se da orla do tempo que cerca nosso presente, que o domina e que o indica em sua alteridade; é aquilo que, fora de nós, nos delimita. A descrição do arquivo desenvolve suas possibilidades (e o controle de suas possibilidades) a partir dos discursos que começam a deixar justamente de ser os nossos; seu limiar de existência é instaurado pelo corte que nos separa do que não podemos mais dizer e do que fica fora de nossa prática discursiva; começa com o exterior da nossa própria linguagem; seu lugar é o afastamento de nossas próprias práticas discursivas. Nesse sentido, vale para nosso diagnóstico ${ }^{165}$.

A severidade com a qual testemunhamos Foucault a diagnosticar as condições responsáveis pelo soerguimento de nossa atualidade, indicia, ao mesmo tempo, a necessidade que temos de operar cortes: forjar acontecimentos sob os quais experiências inauguram um novo campo de força capaz de nos "afastar de nossas práticas discursivas"; antecipando o que somos - en train de devenir -, isto é, vindo-a-ser. Para tanto, não podemos prescindir da função da história do pensamento, nem da marca que as relações estratégicas e táticas tencionadas com a força dos dispositivos irão operar no âmbito que as experiências desempenharão.

conjuntamente; mas questionamos se de fato não existiria em Foucault uma subjetividade absoluta posta no sentido do acontecimento, ou seja, como ponto de constante ruptura que se inscreve desde os menores acontecimentos capazes de serem produzidos, a partir da fala, por exemplo, na qual o valor se circunscreve como no âmbito da experiência e não do engajamento (cf. GLÜCKSMANN, A. In. Michel Foucault philosophe. Rencontre internationale. Paris, 9, 10, 11 janvier 1988, p.395-398). Neste sentido, apelamos para uma importante citação de Foucault: "Meu modo de não ser mais o mesmo é, por definição, a parte mais singular do que sou" (Pour une morale de l'inconfort. Dits et Écrits III, № 266, 1979, p.784). Notemos bem: se o singular é parte do acontecimento, o que cada um pode ser não está nem além nem aquém de um acontecimento singular. Portanto o acontecimento passa a ser noção-instrumento importante nas estratégias de subjetividade.

${ }^{164}$ FOUCAULT, M. Qu'est-ce les Lumières? Dits et Écrits IV, $\mathrm{N}^{\circ} 351,1984, \mathrm{p} .687$.

${ }^{165}$ FOUCAULT, M. A arqueologia do saber, p.15-151. Aqui somente fizemos questão de mencionar en passant a noção de arquivo, pois ela já nos habilita a pensar a dimensão que o acontecimento ocupa na história como diagnóstico. No capítulo seguinte, este tópico será tratada com mais propriedade. Fora isto, devemos registrar que, neste contexto, estamos partilhando a interpretação que Deleuze dispensa à atualidade: "A novidade de um dispositivo em relação aos precedentes denominamos de atualidade, nossa atualidade. $\mathrm{O}$ novo é o atual. $\mathrm{O}$ atual não é o que somos, contudo, mais o que nós nos tornaremos, o que nós estamos vindo-a-ser (en train de devenir), isto é o Outro, nosso vir-a-ser-outro". (DELEUZE, G. Qu'est-ce qu'un dispositif? In. Michel Foucault philosophe. Rencontre internationale. Paris, 9, 10, 11 janvier 1988, p.190-191) 
Assim, se a identidade congela o gesto do pensamento, sob o ângulo do acontecimento-diagnóstico, vemos uma acontecimentalização da história (événementialization) $^{166}$, que faz sentido ao empreendimento de uma história insistente do pensamento, sobretudo quando vislumbramos as manobras que Foucault realiza para se livrar de uma "especificidade do saber" e, com isto, procurar "reinterrogar o conhecimento, suas condições e o estatuto do sujeito" ${ }^{167}$. Quer dizer, colocar em causa as transformações exigentes cujos diferentes domínios de relações se estabelecem a partir do momento em que o próprio pensamento se inscreve como diferença pelo fato de ser acontecimento. Se, de fato, for assim, o pensamento não pode deixar de ser pulsão intermitente a provocar cortes inevitáveis sob a circunscrição da experiência. Pensar é ter determinada experiência: "estamos hoje na idade onde a experiência - e o pensamento se faz a não ser com ela - se desenvolve como uma riqueza singular ao mesmo tempo numa unidade e dispersão que apagam as fronteiras das províncias outrora estabelecidas" ${ }^{168}$. Mais do que um aparente oxímoro, cremos que a unidade representa a provisorieidade alcançada na presença de cada enunciado que ganha vida paralelamente na proporção de sua enunciação. Contudo, como este jogo se reduplica, fazendo-se e desfazendo-se, na medida de cada descrição empreendida, o que temos, por conseqüência, é uma dispersão. Assim, o pensamento existe ao passo que não possui identidade vinculada a nenhum lugar ou sujeito cujas ligações pudessem servir como fundo. O pensamento é algo que se exerce tal como é:

mau, paradoxal, surgindo involuntariamente no ponto extremo das faculdades dispersadas; devendo se livrar incessantemente da estupeficante bobagem (stupéfiante bêtise); submetido, constrangido, forçado pela violência dos problemas; sulcado, como que por clarões de idéias distintas (porque agudas) e obscuras (porque profundas).

\footnotetext{
${ }^{166}$ Embora estranho, o termo que utilizamos aqui é o mais fiel possível à expressão événementialization, événementialiser, referindo-se ao acontecimento (événement), utilizado com fartura por Foucault pelos menos desde 1978 com Qu'est-ce que la critique (What is critique? p.393 sobretudo) e em Table ronde du 20 mai 1978 (Dits et Écrits IV, No 278, 1980, p.23-25, especialmente). O próprio Foucault, neste sentido, pede perdão "pelo horror da palavra", no primeiro texto que citamos. Fazemos destes termos a nossa declaração.

${ }^{167}$ FOUCAULT, M. Titres et travaux. Dits et Écrits $I, \mathrm{~N}^{\circ} 71,1969$, p.846.

${ }^{168}$ FOUCAULT, M. C'était un nageur entre deux mots. Dits et Écrits I, № 43, 1966, p.556. Este contexto é vital para a tese que sustentamos, ou seja, que em Foucault é possível alcançarmos uma história da subjetividade ocidental cujos planos aprofundam, reproblematizam e redimensionam incansavelmente os vários núcleos de experiências históricas desta constituição em foco. Por quê? Porque, apesar de todo efeito de fissuras nitidamente presenciadas nos interesses divergentes de problematização a ser historiada, persiste o fundo cuja preocupação é a latente história do pensamento. Isto é visto em Titres et travaux, texto de 1969, em que Foucault delineia o foco de suas pesquisas futuras, de fato concretizadas com a posse no Collège de France da cadeira História dos sistemas de pensamento, substituindo seu antecessor - Jean Hyppolite, cuja cadeira denominava-se História do pensamento filosófico - até 1984, crepúsculo da trajetória foucaultiana, quando ainda encontramos a persistente idéia de se fazer "um trabalho de historiador como trabalho da história do pensamento", conforme em Le souci de la vérité (Dits et Écrits IV, № 350, 1984, p.668).
} 
Deste modo, ele "não é mais um olhar aberto sobre formas claras e bem fixadas em nossa identidade; ele é gesto, salto, dança, afastamento extremo, obscuridade tencionada" "169. As experiências, então, estão sujeitas a uma prática de inversão nos valores de luminosidade ou visibilidade, pois não se dão somente em um plano de discursividade, planos de unidades e coerências lógicas, mas subjazem no esteio de práticas que, na superfície, talvez, não fariam sentido ao pensamento, mas que, visto de suas fissuras irregulares e de seu arquivo, revelam que o próprio pensamento é acontecimento experimentado sob as condições mais improváveis.

Sob este cenário, três conseqüências decorrem atingindo o estatuto da história do pensamento. Em primeiro lugar, ela "parece multiplicar as rupturas e buscar todas as perturbações da continuidade" ${ }^{170}$, pela evidente dinâmica que iremos encontrar entre a experiência do pensamento e as condições improváveis e até então impensadas para que ele fosse exercido. Segunda conseqüência: o pensamento está desalojado da reflexividade da consciência e torna-se oscilação indefinida como figura retalhada e lacunar, pois alcança contorno na medida de sua dependência de cada acontecimento; e, do ponto de vista do empreendimento histórico, do trabalho de descrição a envolver todas as possibilidades enunciativas. Ainda a este propósito, tal descrição não está aportada numa "referência à interioridade de uma intenção, de um pensamento ou de um sujeito, mas segundo a dispersão de uma exterioridade" ${ }^{\prime 171}$, ou seja, as dobras visíveis por intermédio das quais nos deparamos com as redes "indispensáveis por onde nós nos tornamos legíveis, nós e nossa cultura" ${ }^{172}$. Sob este ângulo, finalmente, uma linha incandescente irá se ativar, retraçando o próprio sentido do pensamento e firmando diante dele a infatigável ligação, para além do edifício dos discursos, com as práticas sociais abrigadas, dissipadas, forjadas, transformadas sob a cadente mutação silenciosa, porém visível, cuja penetrabilidade se enraíza micropilarmente até nas mais simples instituições. Eis aqui a razão para isto:

o pensamento, isto existe, se bem que de um lado e de outro dos sistemas e dos edifícios de discursos. É qualquer coisa que se esconde freqüentemente, porém sempre anima os comportamentos cotidianos. Invariavelmente há um pouco de pensamento mesmo nas instituições simples (sottes); sempre há pensamento mesmo nos hábitos $\operatorname{mudos}^{173}$.

\footnotetext{
${ }^{169}$ FOUCAULT, M. Ariane s'est pendue. Dits et Écrits I, No 64, 1969, p.769.

${ }^{170}$ FOUCAULT, M. A arqueologia do saber, p.06.

171 Ibidem, p. 144.

${ }^{172}$ FOUCAULT, M. La folie, l'absance d'oeuvre. Dits et Écrits I, No 25, 1964, p.412.

173 FOUCAULT, M. Est-il donc important de penser? Dits et Écrits IV, No 296, 1981, p.180.
} 
O que, portanto, permitiu a Foucault traçar um corte transversal atingindo, de fio a pavio, a sua trajetória, ainda que concomitantemente estivesse manifestando qual é a sua engrenagem principal, podemos entender pela interpretação que dispensamos à história do pensamento. É claro, para nós, que as análises dos edifícios de discursos não poderiam produzir o alcance necessário para entendermos os processos e movimentos de forças às quais estamos suscetíveis; nem as sinuosidades que encerram a pletora de pontos de inflexão e dispersão de práticas atinentes aos acontecimentos que tornaram possíveis os campos de nossas experiências: forças incontornáveis dos planos e campos de nossa subjetividade. É assim que, a partir de 1975, com o surgimento de Vigiar e punir: história da violência nas prisões, deparamo-nos com melhores condições de apreendermos o jogo de luz e sombra que articulam e movimentam as expressões de comportamento e cognição humanas cuja dobradiça é o cotidiano visível de todas as experiências de vigilância, punição, administração temporal e ação sobre os corpos humanos, disciplinarização, cuja dimensão prisional é um mero acontecimento - recorte - em meio a tantos outros a testificar o incansável dinamismo histórico, palpável e ao alcance de todos nós, sob o qual estamos ligados. O vigor das instituições, enunciados não discursivos, é mais presente em nós do que a permanência fugaz do presente sob o qual somos constituídos.

É forçoso, contudo, tomarmos ciência do que nos afronta. E com este intuito, Foucault posiciona-se na extensão de um empreendimento de inconteste relevância, já que, por seu intermédio, um novo estrato da história vem a lume a fim de agitar a nossa atualidade e repluralizar os nossos acontecimentos. A questão pode ser assim colocada: dizendo-nos que se "sob sua forma mística ou ascética, o exercício era uma maneira de ordenar o tempo aqui de baixo para a conquista da salvação", por outro lado,

vai pouco a pouco, na história do Ocidente, inverter o sentido guardando algumas características: serve para economizar o tempo da vida, para acumulá-lo de uma maneira útil, e para exercer o poder sobre os homens por meio do tempo assim arrumado. $\mathrm{O}$ exercício, transformado em elemento de uma tecnologia política do corpo e da duração, não culmina num mundo além; mas tende para uma sujeição que nunca terminou de se completar ${ }^{174}$.

Ora, de nossa parte, julgamos encontrar nestes termos uma série de confluências decisivas do ponto de vista do contato entre história e subjetividade. Por um lado, a ênfase no aspecto prático a se relacionar com campos de saberes que, sob um jogo de transformação que vem sendo analisado desde a História da loucura, exercerão determinadas forças cuja instalação e

${ }^{174}$ FOUCAULT, M. Vigiar e Punir, p.146. Grifos nossos. 
campo de ação dizem respeito não diretamente à razão, consciência ou psique humana, ao contrário, ao corpo como partícula que sofre uma carga de forças-ações para ser sucumbido a certos efeitos e, portanto, sujeitado. Por outro lado, as linhas confluentes ultrapassam o seu centro gravitacional, pois não há limites para a configuração de forças, e atravessam um vazio, expressão de expectativa, à medida que nos permite indagar sobre as possibilidades e artimanhas necessárias para a construção de horizontes que não sejam reduzidos a esta história de sujeição. Mas isto mesmo seria possível? Talvez, mas não sem o enfrentamento de uma realidade que se impõe em sua pura objetividade; não sem abrir mão da cartografia cuja insistência em mapear as sombras de nossa sujeição desaguará na certeza de que se, por meio de práticas, não percebíamos a clara força exercida sobre nossa constituição não era por deficiência de luz, mas porque estava claro demais. É assim que faz sentido vermos em Vigiar e Punir um trabalho que, doravante, passa a sublinhar não mais os distantes sítios de saberes de onde falávamos, pensávamos, vivíamos, enfim, "história do passado"; porém, de agora em diante, história "nos termos do presente", como "história do presente"175. Mas como assim?

A História da violência nas prisões põe em cena a incansável relação de força exercida nos espaços onde discursos e instituições se imiscuem como função de sistema de coerção (système de contrainte) ${ }^{176}$. E, sob este registro, o presente atualiza-se e dissemina-se a partir de uma série de forças vetoriais, pois trata-se de pontos móveis e aplicação de força que, estabilizados, embora momentaneamente, exercem ações voltadas para a conduta a fim de alcançar uma multiplicidade humana qualquer. A história como relação de força é

${ }^{175}$ Ibidem, p.32. Gostaríamos de enfatizar o quanto este quadro, de fato, é decisivo. Nele vemos Foucault assumindo a história como um importante instrumento. Por quê? De um lado, sob o ponto de vista da pura descrição, nosso autor põe a olho nu uma certa objetividade, a microparticularidade da prisão; mas, ao fazer isto, começamos a encontrar meios intelectuais não somente para entender esta objetividade, como também para suprimi-la ou evitá-la, ou ainda agir sobre ela. Ou seja, a descrição da prisão como acontecimento suscita em nós a construção de novos acontecimentos. Não é de se ignorar que esta obra, particularmente, faz parte do contexto de lutas com as quais Foucault se engajara, desde o início dos anos setenta, com o G.I.P - Groupe d'information sur les prisons (especificamente em 08 de fevereiro de 1971). Concernente a isto, é de extrema valia a interpretação de Farge: "A objetividade da história reside na possibilidade para seu sistema de inteligibilidade de introduzir o que vem desarranjar sua linearidade, suas abordagens comuns, algo parecido com a sua serenidade. Uma narrativa histórica que carrega sentido e verdade para o presente é uma narrativa capaz de assumir o arrombamento das dores evocadas. Trabalhar com o sofrimento e a crueldade na história também é querer erradicá-la no presente. Explicando os dispositivos e os mecanismos de racionalidade que os fizeram nascer, o historiador pode dar meios intelectuais para suprimi-los ou evitá-los". (FARGE, A. Des lieux pour l'histoire. Paris: Seuil, 1997, p.26-27). Ainda a propósito desta questão, podemos enxergar nisto, conforme sugerimos, o passo inicial em direção ao Esclarecimento com que Foucault se ocupará depois e não mais abandonará, notadamente com a ênfase tardia no papel do intelectual específico. (Podemos ver isto a partir de 1978, com Qu'est-ce que la critique? Critique et Aufklärung. Cf. What is critique? p.382-398; em Qu'est-ce que les Lumières? Dits et Écrits IV, $\mathrm{N}^{\circ} 339$ e 351, 1984) Cremos, ainda, que todo este enfoque encontrará azo no instante em que a história dos sistemas de pensamento torna-se história crítica do pensamento.

${ }^{176}$ A expressão se encontra em Le jeu de Foucault. Dits et Écrits III, No 206, 1977, p.301, sob o seguinte contexto: "O que se designa geralmente por 'instituição' é todo comportamento mais ou menos coagido, ensinado. Tudo o que, numa sociedade, funciona como sistema de coerções, sem ser um enunciado, todo social não discursivo, é a instituição". 
concebida por dispositivos. Neles, os indivíduos e grupos humanos são tocados por técnicas e tecnologia de poder - vetores distintos de forças -, que vão cuidadosamente fabricando individualidades e coletividades ao mesmo tempo que utilizarão táticas e estratégias diferenciadas. Sob estas estratégias, agita-se uma pluralidade de forças que sujeitam ${ }^{177}$. De que maneira, contudo?

O dispositivo, noção cardinal e de complexa movimentação, permitirá um interessante movimento de rotação na história, cumprindo um duplo papel. Em um eixo, mostrará a inevitável potência existente na inexorável constituição de subjetividades a partir de engrenagens cuja mecânica é sustentada por forças combinatórias, representadas por tipos múltiplos de poder; e, pela própria multiplicidade de forças que se atribui à história, busca aquela cuja força motriz poderá, senão mudar o eixo de aplicabilidade existentes, no mínimo, paralisar ou buscar na diferença uma especificidade cujo vetor atua na direção de uma reversibilidade do acontecimento homogêneo. Se nos colocamos neste horizonte, é porque julgamos que a tríplice característica do dispositivo já indicia a necessidade do afrontamento ou embate inevitável entre a constituição das forças histórica, senão vejamos.

O dispositivo, em primeira mão, não descartará a importância que o saber ocupa como causa e entendimento dos mecanismos históricos de nossa constituição. Fundamentalmente, ele representa "estratégias de relações de forças suportando tipos de saber, e suportado por eles" ${ }^{178}$, ou seja, é por esta via que desde Vigiar e Punir "o poder produz saber; que poder e saber estão diretamente implicados; que não há relação de poder sem a constituição correlata de um campo de saber, nem saber que não suponha e não constitua ao mesmo tempo relações de poder"; o que temos, portanto, são "relações de "poder-saber""179. Ora, isto é assim porque

\footnotetext{
${ }^{177}$ Importante esclarecer o leitor que a mecânica da força do ponto de vista de seu exercício na constituição da subjetividade ocidental será pormenorizada no terceiro capítulo. O nosso interesse, aqui, é circunstanciado pelo objetivo do capítulo: mostrar como a mutação nos domínios dos estudos históricos desvela novas perspectivas para a compreensão dos campos de subjetividade que são todos eles históricos, portanto múltiplos, descontínuos, seriais, porém estratos que, ao serem relacionados, intensificam não somente a temática enquanto problematização como também desloca a nossa compreensão-intepretação para um novo patamar de entendimento e ação interligado ao que somos e queremos ser. É nesta direção, por exemplo, que podemos pensar a interpretação que Revel dispensa a esta história consignada a uma força irrefutável e incontornável posta nos mais distintos espaços e momentos da história. Ao afirmar que "a estratégia serviu para reforçar a convicção de que os atores agiam no seio de um dispositivo institucional inexorável", vemos abrir perante nós a indagação elementar, mas de difícil resposta, que corrobora a importância do acontecimento na fragilidade do instante que vivemos: e daí, o que faremos? (REVEL, J. Machines, stratégies, conduites: ce qu'entendent les historiens. In. Au risque de Foucault. Paris: Supplémentaires, 1997, p.120). Assim, se há em Vigiar e Punir uma espécie de "inauguração de uma perspectiva nova", nos termos de Ewald, ela se deve justamente pelo fato de nos oferecer uma nova ferramenta, com o propósito de convocar "novas atitudes e novas aptidões" (EWALD, F. Anatomie et corps politiques. In. Critique. Paris: Minuit, Dez. 1975, Tomo XXXI, No 343, p.1228-1229).

${ }^{178}$ FOUCAULT, M. Le jeu de Michel Foucault. Dits et Écrits III, Nº 206, 1977, p.300.

${ }^{179}$ FOUCAULT, M. Vigiar e Punir, p.30. Dois comentários que julgamos importantes. À vista disto, devemos observar com bastante cuidado o juízo que Revel elabora ao afirmar que "na realidade, a noção de dispositivo substitui (remplace) pouco a pouco aquela de épistémè, empregada por Foucault, particulamente em Les Mots et
} 
o dispositivo é um conjunto eminentemente heterogêneo "comportando discursos, instituições, organizações arquiteturais, decisões regulamentares, leis, medidas administrativas, filantrópicas, proposições filosóficas, morais”, de modo que deve ser concebido como uma "rede que se estabelece entre estes elementos" $" 180$. Rede: as relações de saber que implicarão na eficácia do poder. Daí o fato de pensamos no registro de forças, ou seja, a força vale como expressão estratégica (armação) e tática (ação) para o máximo de variação possível que encontramos na história de saber-poder. Assim, a força desfaz a capacidade tanto do saber quanto do poder de dizerem $E U$, pois a proeminência do dispositivo não evidencia o ponto de partida ou de origem das forças de modo conclusivo e unívoco.

Entretanto não estaria assim o dispositivo condenado a uma generalização tão ampla que geraria, em princípio, uma contradição ou ineficácia na pretensão de se fundamentar as relações implicadas na "história do presente" a partir de um "estudo desta microfísica de poder" ${ }^{181}$ ? Aparentemente, sim. Mas entendemos que, se o foco for colocado na "ligação que pode existir entre os elementos heterogêneos" ${ }^{\text {182 }}$, o dispositivo, numa segunda característica, será imprescindível para entendermos que todo sujeito é um agenciamento coletivo produzido por forças que se colocam numa lógica da estratégia. A heterogeneidade não é um princípio de exclusão, quer dizer, "jamais impede nem a coexistência nem junção ou a conexão" de elementos que se dão por laço, ligação - rede. Não se trata, então, de generalização, porém de amplitude, lógica da estratégia que "tem por função estabelecer quais são as conexões

les Choses até final dos anos de 1960. De fato, continua a autora, épistémè é um dispositivo especificamente discursivo, enquanto o 'dispositivo' no sentido que Foucault empregará dez anos mais tarde compreende igualmente instituições e práticas, ou seja, 'todo o social não discursivo"” (cf. REVEL, J. Le vocabulaire de Foucault. Paris: Ellipses, 2002, p.25). De nossa parte, cremos que não há uma substituição. O saber é dissolvido sob o regime de uma teoria de forças, donde saber-poder, pois o discurso não deixará de ser fundamental na constituição de toda prática e no suporte de toda instituição. Tanto é, que o dispositivo da sexualidade será um bom exemplo desta relação inconteste: "Esta história da sexualidade, ou melhor, esta série de estudos a respeito das relações históricas entre o poder e o discurso sobre o sexo, devo reconhecer que tem projeto circular, no sentido de se tratar de duas tentativas mutuamente dependentes" (História da Sexualidade 1: a vontade de saber, p.87). Neste sentido, nos colocamos mais próximo de Honneth, para quem as relações de saber nos aproximam do entendimento do "destino do corpo" na história ocidental, notadamente, porque a "representação moderna do sujeito e da moralidade" não pode ser concebida sem prévia análise dos "contextos de estratégia de poder social" (Respectivamente: HONNETH, A. Foucault et Adorno: deux formes d'une critique dela modernité. In. Critique. Paris: Minuit, Ago-set 1986, No 471-472, p.800; HONNETH, A. Critique and Power: recasting the Foucault/Habermas debate. Massachussetts e London: MIT Press e Cambridge, 1994, p.158). Segundo comentário: embora seja usual celebrar Foucault na difusão da expressão saber-poder, não seria injusto apontarmos que, bem antes de nosso autor, Adorno e Horkheimer já sustentavam esta perspectiva em 1944, embora num contexto teórico totalmente distinto, à guisa da Dialética do esclarecimento: "O saber que é poder não conhece nenhuma barreira, nem na escravização da criatura, nem na complacência em face dos senhores do mundo" (ADORNO, T. W. e HORKHEIMER, M. Dialética do esclarecimento. Rio de Janeiro: Zahar, 1985, p.20).

${ }^{180}$ FOUCAULT, M. Le jeu de Michel Foucault. Dits et Écrits III, № 206, 1977, p.299.

${ }^{181}$ FOUCAULT, M. Vigiar e punir, p.29.

${ }^{182}$ FOUCAULT, M. Le jeu de Michel Foucault. Dits et Écrits III, No 206, 1977, p.299. 
possíveis entre termos absurdos e que permanecem absurdos" ${ }^{183}$. Nesta via, o dispositivo, mais do que se afastar de relações homogêneas, vê em cada pequeno segmento de relação heterogênea, a força que há entre cada elemento, exercendo um “jogo de mudanças de posição, de modificações de funções, que podem ser muito diferentes"184.

É desta forma que, finalmente, faz sentido concebermos o dispositivo sob os termos de uma formação mutatis mutandis. Formação: emersão e contornos diferentes com velocidades, intervalos, intensidades e aplicações difusas em que, num dado momento histórico, teve e tem por função preponderante responder a uma urgência, isto é, ele "tem uma função de estratégia dominante" ${ }^{, 185}$. Fluxo de qualquer formação, a urgência emerge como acontecimento transpassado de ligações multíplices: dispositivo-dobradiça. Corpo-prisão-acontecimento; corpo-sexualidade-acontecimento; corpo-loucura-acontecimento; corpo-saber-acontecimento; corpo-urgência-dispositivo: “o estudo desta microfísica supõe que o poder nela exercido não seja concebido como uma propriedade, mas como estratégia, que seus efeitos de dominação não sejam atribuídos a uma 'apropriação, mas a disposições, a manobras, a táticas, a técnicas, a funcionamentos" ${ }^{186}$. A história dispositivada é a dos pontos-agentes sobre os quais a força exerce seus efeitos: produz. Estamos diante da incansável produção de mecanismos próprios de qualquer acontecimento: panóptico, divã, asilo, escola, hospital, população, indivíduo multiplicidades humanas, discursivas, institucionais.

\footnotetext{
${ }^{183}$ FOUCAULT, M. Naissance de la biopolitique, p.44.

${ }^{184}$ FOUCAULT, M. Le jeu de Michel Foucault. Dits et Écrits III, N 206, 1977, p.299.

${ }^{185}$ Ibidem, Id.

${ }^{186}$ FOUCAULT, M. Vigiar e punir, p.29. Faz muito sentido, neste contexto, a interpretação que Deleuze arquiteta em torno do dispositivo. Para este autor, o dispositivo é um fiapo, tênue linha (écheveau), mas num conjunto multilinear que se compõe e comporta-se de dois modos: geral e particular. Assim, em seu aspecto geral, "o dispositivo é composto de linha de natureza diferente. E estas linhas no dispositivo não fecham ou circulam sistemas em que cada um seria, por sua conta, homogêneo, o objeto, o sujeito, a linguagem etc, mas seguiriam direções, traçando processos sempre em desequilíbrio, ora reaproximando-se, ora distanciando-se uns dos outros. Cada linha é quebrada, submetida às variações de direção, bifurcada e fendida, submetida às derivações. Os objetos visíveis, os enunciados formulados, as forças em exercício, os sujeitos em posição são como vetores ou tensores". Sendo assim, é possível concebermos que Foucault vai descobrindo novas dimensões de linhas que são "cadeias variáveis que se interpenetram umas com as outras". Com efeito, o caráter particular ou específico do dispositivo seriam regimes de visibilidades distintas definidas pelo que é enunciável "com suas derivações, suas transformações, suas mutações". Quer dizer, saber, poder e subjetivação seriam curvas distintas dos dispositivos: saber: "curvas de visibilidade e de curvas de enunciação"; poder: "linha de força"; subjetivação: "processo, produção de subjetividade num dispositivo", "linha de fuga" em que o Si (Soi) "não é nem um saber nem um poder" (DELEUZE, G. Qu'est-ce qu'un dispositif? In. Michel Foucault philosophe. Rencontre internationale. Paris, 9, 10, 11 janvier 1988, p.185-195. Aqui, as citações estão compreendidas entre as páginas 185-187). Notemos bem que, desta maneira, o dispositivo atravessa toda trajetória das questões foucaultianas, ensejando uma problemática de alcance inestimável concernente à ligação história e subjetividade. É certo, contudo, que Deleuze faz isto a seu modo, ou seja, a partir da noção de linha que é fundamental na arquitetônica de sua filosofia. Mas julgamos que, apesar desta especificidade, como estamos sustentando, as questões atinentes aos campos de Saber, Poder e Subjetivação se dinamizam em um cenário que pode bem ser o da história do sujeito ocidental.
} 
É neste mesmo sentido, a nosso ver, que devemos, então, entender o "caráter minúsculo" da história, como vemos ser sustentado desde 1976 com a História da sexualidade: a vontade de saber ${ }^{187}$. Caráter que enfatiza, sem dúvida alguma, as instâncias e transformações de produção discursiva, de poder e saber, mas em seus focos-locais de produção - prisão: foco-local onde o "indivíduo é cuidadosamente fabricado, segundo uma tática das forças e dos corpos"; sexualidade: foco-local em torno do sexo enquanto "multiplicação do discurso", incitação à fala - tagarelice "tratando de proteger, separar e prevenir, assinalando perigos em toda parte, despertando as atenções, solicitando diagnósticos, acumulando relatórios, organizando terapêuticas"; população: foco-local de "regulações, controle e gerenciamento" das massas - seus movimentos e ações - "gestão calculista da vida"188. Focos-locais de sujeição. A história está repleta de oficinas de sujeição. Algo de muito esclarecedor pode ser encontrado nestas palavras que, talvez, tenha um peso para a trajetória de Foucault instalada até aqui:

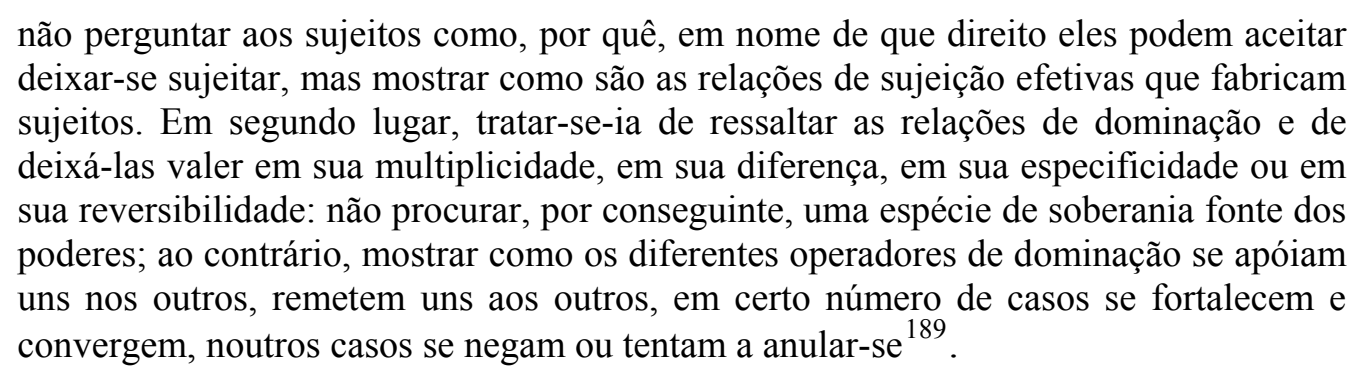

A história está franqueada por regimes de sinais a indicar a longa jornada de relações de sujeições efetivas. Mas como alguém se reconhece neste fluxo interminável? O fato é que também estamos instalados nos espaços de um poder-verdade: vontade de verdade, balizas objetivas de nossas experiências. Experiências: correlações, "numa cultura, entre campos de saber, tipos de normatividade e formas de subjetividade" ${ }^{190}$.

O aprofundamento por buscas dos campos de nossas experiências, "o que estava preparado há muito tempo" ${ }^{191}$, entretanto, tem o seu ápice no eixo do entendimento da história enquanto transformação. É espantoso o salto operado por Foucault entre $A$ vontade de saber de 1976 e os dois últimos volumes da História da sexualidade de 1984. Não mais áreas recentes de nossa experiência de subjetividade, mas áreas deslocadas desde o século V a.C. a

\footnotetext{
${ }^{187}$ FOUCAULT, M. História da sexualidade: a vontade de saber, p.33.

${ }^{188}$ Respectivamente: FOUCAULT, M. Vigiar e punir, p.190; História da sexualidade: a vontade de saber, p.32$33 ;$ p. 131 .

${ }^{189}$ FOUCAULT, M. Em defesa da sociedade, p.51.

${ }^{190}$ FOUCAULT, M. História da sexualidade 2: o uso dos prazeres, p.10.

${ }^{191}$ FOUCAULT, M. História da sexualidade 1: a vontade de saber, p.149.
} 
fim de ressaltar esta estranha "tarefa de evidenciar alguns elementos que possam servir para uma história da verdade", ou seja, de como, por mais estranho que nos parece, o "ser se constitui historicamente como experiência, isto é, como podendo e devendo ser pensado"192.

Todavia esta estranha operação tem um sentido importante para a tarefa da força histórica. Ela produzirá um forte centro de gravidade, melhor dizendo, uma força motriz de potência inigualável pelo fato de indagar pelo presente em questão não mais pelo fluxo das objetivações do sujeito; das sujeições incontornáveis, linhas rígidas de nossas experiências. Ora, mas como isto não pode ser superado, implodido, ignorado, pois o seu valor estruturante tem um peso marcante em nossa constituição, ou seja, a subjetividade é produzida por meio das forças objetivantes, novos processos poderiam ser pensados a fim de que este jogo de sujeição sofresse uma reapropriação ou um outro tipo de ligação, uma ligação do sujeito consigo mesmo, talvez numa série constante de deslocamentos. Então, para que isto ocorresse, vemos os esforços que Foucault arregimenta com o intuito de engendrar um novo registro e estatuto vinculado ao modo de ser. Modos, seria o mais correto. Afinal, se a subjetividade é imanente às variantes históricas, logo, descontínuas, como a história pode tomar os acontecimentos e o pensamento à guisa de estratégias de problematização? Imbuído por este propósito, a década de 1980 assinalará com a história crítica do pensamento, mais do que uma nomenclatura novel, uma perspectiva beligerante no fluxo das transformações e da insistente forma de o pensamento se repor - transmutavelmente - como modificação exigente de uma história aberta que não cessará de modificar as acepções e recepções da relação entre sujeito e objeto: quais são os meios para se conhecer a verdade? Eis a questão.

Segundo a nossa interpretação, o que estará em jogo é a produção histórica de heterótipos sob o campo heterotopológico da crítica como força de afrontamento às ortopedias sociais, discursivas e de governamentalização generalizada que sempre funcionaram como "mecanismo de estabelecimento da verdade" $" 193$. Como nos libertar do que se passou? Se nossas origens estão sub-repticiamente dispostas em práticas, que continuam a atuar em nossas condições de existências, como, então, forjar condições para a "modificação de temas preexistentes", para nos valermos de uma idéia de $O$ cuidado si, a fim de podermos reconhecer campos nos quais podemos "reconhecer o desenvolvimento de uma arte da existência dominada pelo cuidado de si" 194 em lugar das relações constritoras de saber-poder que investem em toda trama de nossa existência? Será preciso a criação de um procedimento

\footnotetext{
${ }^{192}$ FOUCAULT, M. História da sexualidade 2: o uso dos prazeres, p.12.

${ }^{193}$ FOUCAULT, M. La vérité et les formes juridiques. Dits et Écrits I 1954-1975, No 139, 1974, p.1425.

${ }^{194}$ FOUCAULT, M. História da sexualidade 3: o cuidado de si, p.234.
} 
histórico que ao mesmo tempo tornar-se-ia uma "máquina crítica" cuja função é essencialmente libertadora ${ }^{195}$. Mas nos libertar do quê? Dos jogos de relações desenhados ao longo da história do Ocidente, responsáveis pela constituição de nossa subjetividade, das distribuições dos papéis e arranjos das cenas, já que são também os espaços de onde nos colocamos para saber e pensar; onde os comportamentos individuais e coletivos foram meticulosamente urdidos; onde as expectativas políticas de subjetividade subjazem a um controle predefinido de ações discursivas e não discursivas. Uma crítica, desta maneira, consistirá "em ver sob quais tipos de evidências, de familiaridades, de modos de pensar adquiridos e não refletidos repousam as práticas que se aceita"; de um modo mais claro: "fazer a crítica é tornar difícil os gestos demasiados fáceis"196. Assim, a crítica é absolutamente indispensável para toda transformação.

Sob um ângulo transversal, as temáticas foucaultianas, talhadas nas mais distintas formas e com tonalidades inigualáveis, fazem emergir uma história que, seja ela a do saber ou da razão, da loucura ou das relações de poder, da sexualidade, enfim das questões de subjetividade, não obedecem a um mesmo modelo. Mas também não se organizam ou se dispõem no mesmo curso do tempo vivido e não têm necessidade de passar por um sujeito fundador, pelo homem como sujeito.

\subsection{História crítica do pensamento}

Já no prefácio de 1961 da História da loucura, Foucault insistia no aspecto necessário de renunciar ao conforto das verdades terminais e de não se deixar jamais guiar pelo que se pode saber de algo. De nossa parte, julgamos que a história cumprirá o papel de ser esta "região incômoda". Sem um Geist condutor, não é possível pensarmos em sucessão, evolução ou significações sedimentadas na espessura da linha do tempo. É por isto que

lá onde se narrava a história da tradição e da invenção, do antigo e do novo, do morto e do vivente, do fechado e do aberto, do estático e do dinâmico, eu começo a narrar a

\footnotetext{
195 Notemos bem a importância deste aspecto. Apesar de encontrarmos a referência à História crítica do pensamento, de maneira nítida, em 1984, já é possível vermos o quanto Foucault atribuía há uma década um peso importante à crítica desde a arqueologia: "A arqueologia é uma máquina crítica, uma máquina que recoloca em questão certas relações de poder, máquina que tem, ou pelo menos deveria ter, uma função libertadora" FOUCAULT, M. La vérité et les formes juridiques. Dits et Écrits I 1954-1975, No 139, 1974, p.1512.

${ }^{196}$ FOUCAULT, M. Est-il donc important de penser? Dits et Écrits IV, No 296, 1981, p.180.
} 
história da perpétua diferença; mais precisamente, de narrar a história das idéias como o conjunto das formas específicas e descritivas da não-identidade ${ }^{197}$.

Neste contexto, o que está em jogo não são os pares dicotômicos, frutos de um pensamento calcado na binomia sujeito/objeto, herança e solo fértil do pensamento ocidental. Todavia o que se delineia é a insurgência de um questionamento acerca de determinada perspectiva histórica que, seja como for, toma o seu objeto como dado. Ademais, vemos um empreendimento de perpétua rejeição da repetição interpretativa ou valorativa dos objetos perseguidos, então, por um tipo específico de pensamento que criava a sua narrativa a partir do objeto histórico já concebido. Em outros termos, o que importa é conhecer as condições históricas que motivam um tipo de ligação ou modo de relação de um objeto com a sua historicidade.

Ora, decorre desse tratamento dado ao objeto, contudo, uma referência também específica a um tipo determinado de sujeito que se relacionará de igual modo de uma maneira específica ao objeto. Então, ao negar ao objeto natural uma forma distinta de concebê-lo, vem à tona e com ela, por conseguinte, uma expressão inovadora: o que é feito, o objeto, explicase pelo que foi o fazer em cada momento da história e, daí, como os sujeitos se fizeram e refizeram-se historicamente para se relacionar com seus objetos ${ }^{198}$.

É por essa razão que o pensamento tem de ocupar uma esfera de contornos precisos. De pretensão parcíssima, desarraiga-se da idéia de querer cobrir um campo imutável cujas relações históricas pudessem se explicar por um fator, um vetor, uma univocidade. Acumulando as experiências urdidas e forjadas por sua tarefa crítica, constante ensaio do que é preciso fazer, o pensamento passa a atuar em uma perspectiva cujo campo de problematização não se cansa de recuar e avançar, dispor e embaralhar, tecer e apagar, enfim, numa dinâmica resiliente. É para este último ponto que Foucault se volta: o ponto das condições históricas.

Sob este registro, podemos nos dirigir para a definição que se impõe, ou melhor, para o entendimento geral do que é a história crítica do pensamento. Se por pensamento, além do que já vimos, diz-nos Foucault, "entende-se o ato que coloca, em suas diversas relações possíveis, um sujeito e um objeto", então, "uma história crítica do pensamento seria uma

\footnotetext{
${ }^{197}$ FOUCAULT, M. Réponse à une question. Dits et Écrits I, No 58, 1968, p.684.

${ }^{198}$ Devemos esta interpretação a Veyne: "Tudo gira em volta desse paradoxo, que é a tese central de Foucault, e a mais original: o que é feito, o objeto, se explica pelo que foi o fazer em cada momento da história: enganamonos quando pensamos que o fazer se explica a partir do que é feito". (VEYNE, P. Como se escreve a história e Foucault revoluciona a história. Brasília: Editora UNB 4.ed., 1998, p.257).
} 
análise das condições nas quais são formadas ou modificadas certas relações de sujeito ao objeto, na medida em que essas relações são constitutivas de um saber possível"199 .

Visto sob essa cunhagem, podemos presenciar a dilatação da amplitude do campo histórico a partir do qual múltiplas relações entre sujeito e objeto podem ser efetivadas ${ }^{200}$. Isso significa dizer que não há objeto nem sujeito dados ontologicamente. Ao contrário, a emersão das diversas relações possíveis existentes entre eles diz respeito a uma tarefa de abertura em que o vir-a-ser constantemente vem a lume e deve ser problematizado. Relação inconteste com o empreendimento de dissolução do falso objeto, porque, longe do esteio das práticas homogêneas que pudessem fundamentar o pensamento ou a história, são as práticas heterogêneas que condicionarão tanto o pensamento quanto o que histórico for.

Nesse sentido, tem um peso determinante o fato de concebermos que "o pensamento tem igualmente uma história; o pensamento é um fato histórico, mesmo tendo ele outras dimensões" ${ }^{201}$. Tal afirmação aponta para caminhos heterogêneos que não repousam na tranqüilidade de uma história absoluta qualquer ${ }^{202}$. Mas, como isto não prescinde de uma tarefa de construção, é necessário um esforço corrosivo com o intuito de problematizar a repetição histórica daquilo que foi a perspectiva ocidental de nossa constituição: é preciso criticar o "nosso ser histórico" 203 . Para tanto, devemos interrogar a dimensão apodíctica de

\footnotetext{
${ }^{199}$ FOUCAULT, M. Foucault. Dits et Écrits IV, No 345, 1984, p.632. Grifo nosso.

200 Somos autorizados, nesse nível, a sustentar que Foucault dissolve a identidade portentosa do que foi a disciplina História, sua totalidade e universalidade. A esse respeito, bem nos aponta Dosse ao dizer que "a história escreve-se doravante no plural e sem maiúscula; renuncia a realizar um programa de síntese para melhor se reorientar no sentido dos múltiplos objetos que se oferecem ao seu olhar sem limites". História do Estruturalismo. V.2. O canto do cisne, de 1967 a nossos dias. Campinas: Editora da Unicamp, 1994, p.292.

${ }^{201}$ FOUCAULT, M. Le souci de la vérité. Dits et Écrits $I V$, № 350, 1984, p.669.

202 Nessa direção, caminham os comentários de Lebrun: "Graças a Foucault, sabemos agora como era ingênuo colocar questões como 'Qual foi a atitude dos romanos do século I em relação ao Sexo?' Ou ainda: 'Em que consistiu a evolução do Ocidente cristão relativamente à Penalidade?' Pois estas questões supõem que 'o Sexo', 'a Penalidade' existiram como objetos definidos de uma vez por todas, e acerca dos quais toda civilização seria forçada a tomar partido." "Assim como é vão pretender escrever a história do objeto "Estado" através das idades. Pois "governar os homens" não é, de forma alguma, um problema eterno que regimes e civilizações, desde os primórdios, teriam precisado resolver [...] Esta expressão não tem o mesmo sentido porque 'governar', aqui e ali, visa a objetivos que nada têm em comum, e remete a práticas heterogêneas”. (Passeios ao léu. Ensaios. São Paulo: Brasiliense, 1983, p.78 e 79).

${ }^{203}$ FOUCAULT, M. Qu'est-ce que les Lumières? Dits et Écrits IV, No 339, 1984, p.571. Referente a este ponto, outra vez invocamos a importância do acontecimento. Se a crítica vai assumir paulatinamente uma relação indissociável com a transformação, podemos afirmar que ela se torna uma "prova de acontecimentalização" (épreuve d'événementialisation), ou seja, uma prova de produção de acontecimento, ou como afirma Foucault, de produção de um "campo de imanência de singularidades puras" (Cf. FOUCAULT, M. What is critique? In. SCHMIDT, J. (Org). What is Enlightenment? Eighteenth-Century answers and Twentieth-Century Questions. California: University of California Press, 1997, p.393-395). Com este propósito, destacamos a interpretação de Fimiani ao entender que "o centro da crítica é o feixe de relação que ligam um a outro, ou um aos outros dois, o poder, a verdade e o sujeito: a crítica não é apenas uma analítica da verdade, mas é, antes de tudo, uma atitude moral e política. É o movimento pelo qual o sujeito se dá o direito de interrogar a verdade sob seus efeitos de poder e o poder sob seus discursos de verdade" (cf. FIMIANI, M. Foucault e Kant. Critique, clinique, éthique.
} 
todos os objetos e, por conseguinte, o modo como os sujeitos se darão em relação a esses objetos, é dizer, ao passo que se constituem sob tais relações.

Ora, as distintas questões historiadas por Foucault não têm outro objetivo a não ser o de fazer evidenciar que nem as coisas nem as palavras possuem existências próprias. A loucura, o saber, a doença, a linguagem, o poder, a sexualidade, para nos atermos a alguns exemplos, possuíram e ainda possuem estatutos, formas, conteúdos, bases e visibilidades que não são homogêneas, muito menos são plasmados por uma mesma essência, um princípio unificador ou uma interioridade constante. Assim é que

o que a razão prova como sua necessidade, ou melhor, o que as diferentes formas de racionalidade concebem como sendo sua necessidade, pode-se perfeitamente fazer a história e reencontrar as redes de contingências de onde a racionalidade emergiu; o que não significa, porém, dizer que essas formas de racionalidade foram irracionais; contudo significa dizer que elas repousam sobre uma base de práticas humanas e de história humana, e uma vez que todas essas coisas são feitas, elas podem, contanto que se saiba como elas foram feitas, ser desfeitas ${ }^{204}$.

Concernentes às múltiplas maneiras pelas quais os fenômenos históricos podem ser narrados pelo pensamento, quer dizer, postos numa visibilidade determinada, alcançamos a superação dos domínios referentes ao comportamento, mentalidade e idéias que, num certo nível, ligam práticas humanas aos feitos, saberes e disposições que podem ser enunciadas como certo ou errado, permissivo ou interdito, normal ou anormal, moral ou imoral, enfim. É evidente, cientes disso, que uma inesgotável possibilidade de tramas históricas perscruta as diversas camadas e heterotopias do próprio pensamento. Conseqüentemente, trata-se da autocriação da razão que não existe de per se; é a história que autoriza a apreensão de sua constituição. A indagação a ser colocada, sob este foco, é a seguinte: como o saber, fazer e pensar foram possíveis de diferentes maneiras? Por isto, é forçoso avaliar se o que se põe historicamente ao pensamento é passível ou não de transformação, e, em certo sentido, por quê. Outrossim, de nossa parte, não seria exagero afirmar, nos termos de Foucault, que é necessário levar em conta as

diferentes instaurações, diferentes criações, diferentes modificações pelas quais as racionalidades se produzem umas nas outras, opõem-se umas às outras, afastam-se umas das outras, sem que para tanto se possa designar para o momento no qual a razão teria perdido seu projeto fundamental, nem mesmo designar um momento onde se teria passado da racionalidade à irracionalidade ${ }^{205}$.

Paris: L'Harmattan, 1998, p.37). Eis, a nosso ver, a razão pela qual Foucault não dissocia a crítica do acontecimento, como demonstra em Qu'est-ce que la critique.

${ }^{204}$ FOUCAULT, M. Structuralisme et poststructuralisme. Dits et Écrits IV, № 330, 1983, p.449.

${ }^{205}$ Ibid. p.441. 
Mas é claro, pois, ao operar as condições em que os diferentes modos de racionalidade se colocam historicamente, também podemos interrogar pela múltipla relação do modo de objetivação do pensamento na história.

Ora, devemos entender por modo de objetivação a interrogação avalizada pelo exercício histórico que se volta para a compreensão e análise das condições em que determinado objeto se coloca para o pensamento. E, de uma maneira inversa, como esse objeto ganhará representação, de uma vez por todas, histórica. Nesse cenário, não sem sentido, é imprescindível, ao que nos parece,

determinar sob que condições algo pôde se tornar um objeto para um conhecimento possível, como ele pôde ser problematizado como objeto a conhecer, sob quais processos de corte (découpage) ele pôde ser submetido, a parte dele mesmo que é considerada como pertinente. Trata-se, portanto, de determinar o seu modo de objetivação, que não é mais o mesmo segundo o tipo de saber de que se trata ${ }^{206}$.

É necessário, contudo, sublinhar que o fato de buscarmos pela condição do objeto coloca à prova a especificidade da própria concepção de pensamento. Auferido por aquilo que Foucault denominou de problemas ou mais exatamente problematizações, o pensamento se move no campo do modo de objetivação, buscando alcançar uma resposta original ou freqüentemente multiforme, uma vez que é na relação com o pensamento que o objeto se faz possível. Foucault fartamente nos esclarece:

o que distingue o pensamento, é que ele é uma coisa totalmente diferente que o conjunto das representações que sustenta um comportamento; de igual modo, ele é outra coisa que o domínio das atitudes que o possam determinar. O pensamento não é o que habita uma conduta dando-lhe um sentido; ele é, de preferência, o que permite tomar afastamento do que se relaciona a essa maneira de fazer ou de reagir, de se dar como objeto do pensamento e de o interrogar sobre seu sentido, suas condições e seus fins. O pensamento é a liberdade em relação o que se faz, o movimento pelo qual ele se libera (détache), se constitui como objeto e se reflete como problema ${ }^{207}$.

Sob esta medida, a história crítica do pensamento deflagra uma postura em que a objetivação e a subjetivação não são independentes uma da outra, aliás, ligam-se num questionamento recíproco. Trata-se, por sua vez, de alargar ou de elaborar um trabalho de dispersão de como o empírico-transcendental se coloca na constituição histórica do pensamento e vai trazendo uma variante dos problemas acerca daquilo que somos, fazemos e pensamos.

\footnotetext{
${ }^{206}$ FOUCAULT, M. Foucault. Dits et Écrits IV, No 345,1984 , p.632.

${ }^{207}$ FOUCAULT, M. Polémique, politique et problématisations. Dits et Écrits IV, № 342, 1984, p.597.
} 
O mais importante, nesse plano, não é o conjunto geral de problemáticas situadas no eixo empírico-transcendental, mas, como não cansou de evidenciar em As palavras e as coisas, o desdobramento desse duplo kantiano, pois ele irá auxiliar na configuração do que ficou conhecido como o "homem" na história ocidental, quer dizer, o homem que se volta para si como objeto de conhecimento. "O umbral de nossa modernidade não está situado no momento onde se aplicou ao estudo do homem os métodos objetivos, porém bem mais no dia em que se constituiu um duplo empírico-transcendental que se chama homem" ${ }^{\text {208 }}$. De nossa parte, sustentamos que o aspecto do duplo empírico-transcendental opera no sentido de indicar que não há uma vantagem na dimensão de um intuitus originarius nem do objeto nem do sujeito. Uma vez que são encontrados na dimensão das condições históricas, ao serem problematizados, no limite, questionam a própria forma em que a razão tentou pensar quer seja objeto ou sujeito ${ }^{209}$.

Assim, repousa na interpretação que Foucault dispensa ao duplo empíricotranscendental a característica de uma história que, de um lado, rejeita a essencialidade do objeto e, de outro, a essencialidade de um sujeito ${ }^{210}$. As palavras de Foucault são elucidativas:

a questão é determinar o que deve ser o sujeito, sob qual condição ele é submetido, qual o estatuto ele deve ter, qual posição ele deve ocupar no real ou no imaginário, para se tornar sujeito legítimo de tal ou tal tipo de conhecimento; em suma, trata-se de determinar seu modo de 'subjetivação'; pois ele, evidentemente, não é o mesmo conforme o conhecimento no qual ele é tratado na forma da exegese de um texto sagrado, de uma observação da história natural ou da análise do comportamento de um doença mental ${ }^{211}$.

\footnotetext{
${ }^{208}$ FOUCAULT, M. Les Mots e les Choses, p.329-330.

${ }^{209}$ Nesse aspecto, concordamos com os termos de Rajchman: “a história de Foucault tenta 'dispersar' o que se presume ser essencialmente um todo. Não temos vidas totais, porquanto não existe uma coisa a que possam ser referidas todas as coisas que nos são atribuídas. Aquilo a que chamamos Razão e Natureza são abstrações vazias, porquanto não existe uma coisa de que todas as nossas ciências tratem, nem um estilo de raciocínio que todas elas empreguem. Não existe um modo único de nos classificar, de classificar o nosso conhecimento ou o nosso mundo. Por conseguinte, a história tampouco existe: não há uma coisa de que todas as nossas histórias tratem, muito embora possa parecer que nada existe sobre o qual não possamos escrever uma história. [...] Em suma, a história está em toda parte, mas difusa ou 'em dispersão"'. (RAJCHMAN, J. Foucault: a liberdade da filosofia. Rio de Janeiro: Jorge Zahar, 1987, p.50-51).

${ }^{210}$ É digno de menção o comentário de Deleuze: "Mas se é verdade que as condições não são mais gerais ou constantes que o condicionado, são, no entanto, às condições que Foucault se interessa. É por isso que ele diz: pesquisa histórica e não trabalho de historiador. Ele não faz uma história das mentalidades, mas das condições sob as quais se manifesta tudo o que possui uma existência mental, os enunciados e o regime de linguagem. Ele não faz uma história dos comportamentos, mas das condições sob as quais se manifesta tudo o que tem uma existência visível, sob um regime de luz. Ele não faz uma história das instituições, mas das condições sob as quais elas integram diferentes relações de forças, no horizonte de um campo social. Ele não faz a história de sujeitos, mas de processos de subjetivação, sob as dobras (plissements) que operam nesse campo ontológico quanto no social" (DELEUZE, G. Foucault. Paris: Éditions de Minuit, 1986, p.124).

${ }^{211}$ FOUCAULT, M. Foucault. Dits et Écrits IV, No 345, 1984, p.632.
} 
De posse desses elementos, podemos também questionar a soberania de um sujeito. $\mathrm{Na}$ mesma proporção que interroga pelos falsos objetos, Foucault nos permite interrogar qualquer sujeito arquetipificado numa série de temas que chancelam a este tópico um privilégio que passa a ser reexaminado, ou melhor, posto em problema. Por conseguinte, a crítica que se exerce ao ser indagado como que um tema, uma norma, uma prática, uma verdade, um saber, enfim, tornaram-se possíveis, permitirá a história esquadrinhar a relação constante e inseparável que haverá entre objetivação e subjetivação.

Quando Foucault publica, ainda em 1969, no Bulletin de la Société française de philosophie, um artigo denominado $O$ que é um autor, portanto, longe do conjunto das problemáticas centralizadas na temática da subjetividade, como querem alguns comentadores, o filósofo já indica, de forma irrecusável, a presença de uma postura preocupada em suscitar alguns questionamentos acerca dessa questão. Rejeitando a modalidade de um sujeito cujo papel seria o de um fundador de discurso, isto é, capaz de carregar um sentido e representação para os objetos de maneira inequívoca, Foucault traz à tona a seguinte questão, sem parcimônia:

não mais colocar a questão: como a liberdade de um sujeito pode se inserir na espessura das coisas e dar a ela sentido, como ela pode movimentar (animer), do interior, as regras de uma linguagem e fazer clarear assim as visadas que lhe são próprias? Mas, antes, colocar essas questões: como, segundo quais condições e sob quais formas algo como um sujeito pode aparecer na ordem dos discursos? Qual lugar ele pode ocupar em cada tipo de discurso, quais funções exercer, e obedecendo quais regras? Em síntese, trata-se de tirar do sujeito (ou de seu substituto) seu papel de fundamento originário, e analisá-lo como uma função variável e complexa do discurso $^{212}$.

Vemos, a partir desse terreno, que não se trata de lançar argumentos com o intuito de justificar a oposição ou sobreposição do objeto e/ou sujeito. Cortados pela incidência

212 FOUCAULT, M. Qu'est-ce qu'un auteur? Dits et Écrits I, No 69 , 1969, p.811. É para nos posicionarmos contrários a um conjunto de perspectivas interpretativas que sustentam uma "virada de fundo ou simplesmente revolução das formulações" do pensamento de Foucault, na expressão de Ferry e Renaut, que tomamos essa citação, embora circunscrita à ênfase do discurso, para expor que o sujeito não é uma questão tardia no pensamento de Foucault. De nossa parte, cremos que a história crítica do pensamento corta, transversalmente, a obra do filósofo, dando a ela um caráter de coerência; e é, no mesmo sentido, que podemos superar as questões que alguns comentadores constroem com a intenção de ver arqueologia e genealogia como etapas totalmente opostas de problematizações. É o caso, como exemplo dos já mencionados Ferry e Renaut, conforme já indicamos na introdução deste trabalho; de Rabinow e Dreyfus, que buscam enfatizar as operações de subjetividade no pensamento foucaultiano, já que sustentam que a arqueologia cede lugar a esse tipo de temática, acometida por um fracasso metodológico, embora, segundo o nosso julgamento, isso ocorra pelo fato dos autores conceberem tão somente que "a arqueologia é uma técnica que pode nos liberar da crença no acesso direto aos objetos; em cada caso, a 'tirania do referente' deve ser ultrapassada" (cf. Michel Foucault: Uma Trajetória Filosófica - Para além do estruturalismo e da hermenêutica. Rio de Janeiro: Forense, 1995, p.130). No entanto é muito claro que encontramos na arqueologia também os caminhos que apontam na tentativa de se alcançar a superação da tirania do referente no que tange ao sujeito, prova disso é a citação de Foucault acima. 
específica da filosofia de Foucault, deparamo-nos com uma história crítica que toma o pensamento na base e nas combinações do que pode ser dado à experiência como possibilidade de problematização, isto é, calcado na instância histórica por intermédio de um labor infinito: constante "reintrodução de diferentes problemas e obstáculos através de formas que estão longe de ser determinadas" ${ }^{, 13}$. Decorre disso, é forçoso dizê-lo, que desde o início do desenvolvimento de sua obra, então, encontramos uma fundação, ou melhor, o desenho da nervura da subjetividade. Perseguidas as condições pelas quais é possível um indivíduo preencher a função de sujeito, a história, ao indagar e precisar o campo no qual o sujeito é sujeito, e de quê (do discurso, do desejo, do processo econômico etc.) não deixa sinais de dúvidas de que a história crítica do pensamento pode ser concebida senão dentro da relação existente entre objeto e sujeito.

É nesse registro que ocorre a problematização crítica advinda da história. Ora, Foucault nos lembra, incessantemente, que os objetos de uma ciência e o que se pode entender por ciência; que as práticas dos homens, suas condutas, seus desejos, o que veio a ser conhecido como Homem, são efeitos estocásticos de uma história sem fundo, ou melhor, sem télos. Daí a necessidade de compreendermos a história crítica do pensamento como a tentativa de se forjar respostas diferentes ao que é diferente. Destarte, a história é problematização, pois "não quer dizer representação de um objeto preexistente, muito menos criação pelo discurso de um objeto que não existe". Aliás, podemos dizer que é problematização, pois se refere ao "conjunto de práticas discursivas ou não discursivas que faz entrar algo no jogo do verdadeiro e do falso e o constitui como objeto para o pensamento (que seja sob a forma da reflexão moral, da consciência científica, da análise política etc.) ${ }^{214}$. Talvez repouse nisso a pertinência de uma indagação que pode aprofundar este ponto: quem ou quê, como e por quê algo nos foi garantido ao pensamento como verdade?

Então, é revirando o fértil solo de onde partimos e nos encontramos como problema histórico que enxergamos o empreendimento foucaultiano se armar, sempre resiliente e incoativo, com o intuito de nos envolver num

movimento de análise crítica pelo qual se tenta ver como pôde ser construídas as diferentes soluções para um problema; mas também como essas diferentes soluções

\footnotetext{
${ }^{213}$ FOUCAULT, M. Le retour de la morale. Dits et Écrits IV, No 354, 1984, p.705. Concorre a nosso favor, também com o propósito de fazer evidenciar ainda mais a tarefa da história crítica do pensamento e a tese que este trabalho vem sustentando, o perspicaz comentário de Deleuze: "Pensar é experimentar, é problematizar. O saber, o poder e o si (soi) são a tríplice Raiz de uma problematização do pensamento". E ainda: "O pensamento pensa sua própria história (passado), mais para se liberar do que ele pensa (presente), e poder enfim pensar de outro modo (futuro)". (DELEUZE, G. Foucault. Paris, Éditions de Minuit, 1986, p.124 e p.127).

${ }^{214}$ FOUCAULT, M. Le souci de la vérité. Dits et Écrits IV, № 350, 1984, p.670.
} 
estão marcadas de uma forma específica de problematização. E, então, pelo visto, toda solução nova que viesse a se ajuntar às outras estaria marcada pela problematização atual, modificando somente alguns dos postulados ou dos princípios sobre os quais se apóiam as respostas em que se dá. O trabalho da reflexão filosófica e histórica se situa no campo do trabalho do pensamento sob a condição que se retoma a problematização não como um ajustamento de representações, mas como um trabalho do pensamento $^{215}$.

Somos autorizados, então, a afirmar que a história não faz a história: não estamos mais diante dessa obrigação; estamos diante das problematizações que abarcam o campo histórico. Desta maneira, o que é preciso fazer é buscar e perseguir a elaboração de uma determinada formação de questão, a sua transformação em conjunto de condições cujo horizonte de dificuldades, obstáculos, nada mais são que espécie de estímulo para procurarmos elaborar e chegar a uma possível resposta, que não fechará o seu campo, mas o abrirá ainda mais para a constituição de outras problematizações, dando assim força à fortuna do trabalho crítico do pensamento. Objeto e sujeito, ou melhor, modos de objetivação e subjetivação, não variam historicamente, mas variam com a história e a sua problematização.

A nosso ver, é sobre esse fundo que se dispõem os arranjos e os sinais da filosofia de Foucault. Suas análises históricas fazem emergir ao pensamento algumas, tão somente algumas, possibilidades de se problematizar seus objetos e seus sujeitos em constituição: a eles não se interroga pela expressão silenciosa que, porventura, pudessem ocultar ou recalcar, também por um dizer silencioso, o que eles são; todavia a eles se indaga sobre o fato e as condições de como vieram a lume, apareceram, manifestaram, porém, não no intuito de entender, saber ou esgotar seus conteúdos, presos naquilo que possam ser, mas, muito mais, para partir em busca das transformações e efeitos que efetuaram e ainda efetuam.

Sob essa regência, todas as coisas foram e ainda são colocadas em variação. A partir de agora, o pensamento possui uma topologia geral, mas também as práticas, os saberes, os poderes, as formas de discurso, as subjetividades. Mas atenção; as variações são todas elas nossas - história crítica do nosso pensamento. Ainda uma palavra a este propósito convém lembrar: parece-nos, são termos de Foucault,

que a aposta, o desafio que toda história do pensamento deve suscitar, está precisamente em apreender o momento em que um fenômeno cultural, de dimensão determinada, pode efetivamente constituir, na história do pensamento, um momento decisivo no qual se acha comprometido até mesmo nosso modo de ser de sujeito moderno $^{216}$.

\footnotetext{
${ }^{215}$ FOUCAULT, M. Polémique, politique et problématisations. Dits et Écrits IV, $\mathrm{N}^{\circ} 342,1984$, p.598.

${ }^{216}$ FOUCAULT, M. A hermenêutica do sujeito, p.13.
} 
Com efeito, se os acontecimentos se atualizam pelas forças que podemos criar de maneira decisiva, então a história pode ser instrumento com o qual produzimos fraturas em todos os níveis de práticas. Dito de outro modo, se as coisas já estão feitas, elas podem, por intermédio das condições que passamos a saber como foram feitas, serem desfeitas. Não seria, assim, o nosso mundo aquele velho palco onde as transformações possíveis não se cansam de se reproblematizarem? O que dizer? Ora, tudo que dizemos poderia ser dito assim: "a história dos homens é a longa sucessão dos sinônimos de um mesmo vocábulo. Contradizê-la é um dever" 217 .

\footnotetext{
${ }^{217}$ A citação é do poeta francês René Char (cf. DAVIDSON, A. I. Les gouvernement de soi et des autres. In. Michel Foucault. Philosophie antologie. Paris: Gallimard/Folio, 2004, p.664).
} 


\title{
II. PARA UMA ARQUEOGENEALOGIA: O MÉTODO DE FOUCAULT
}

\author{
E, se queremos compreender a fala em sua operação \\ mais própria, e de maneira a fazer-lhe justiça, precisamos \\ evocar todas aquelas que teriam podido vir em seu lugar \\ e que foram omitidas, sentir como elas teriam tocado e abalado \\ de outro modo a cadeia da linguagem, a que ponto esta era \\ realmente a única possível, se essa significação devia vir ao mundo... \\ Maurice Merleau-Ponty, \\ A ciência e a experiência da expressão.
}

\subsection{Arqueologia}

Com a arqueologia, podemos colocar em questão as formas de pensamento arraigadas na idéia de um método imutável, sistemático e universalmente aplicado ao que se pretende histórico. Foucault instaura, nessa direção, um processo de ruptura, cujo signo constante é marcado pelo desejo de lançar fora os níveis estabelecidos de codificação desse grande mito ocidental, que foi a história como verdade trans-histórica concreta. A começar por não querer especificar um método formalizador ou interpretativo. Mas como assim? A arqueologia não nos remete àquela de sua composição etimológica: archè, começo ou princípio; mas diz respeito, estritamente, à descrição de arquivo. E devemos entender por arquivo

\footnotetext{
o conjunto dos discursos efetivamente pronunciados; e este conjunto de discursos é visto não somente como um conjunto de acontecimentos que teriam tido lugar uma vez por todas, que restariam em suspenso, no limbo ou no purgatório da história, mas também como conjunto que continua a funcionar, a se transformar através da história, a dar possibilidade de aparecer outros discursos ${ }^{1}$.
}

Acontece, contudo, que quem determina o corpus desse arquivo histórico é a intenção do próprio historiador, que só consegue tal intento na medida em que elabora a sua descrição,

\footnotetext{
${ }^{1}$ FOUCAULT, M. Michel Foucault explique son dernier livre. Dits et Écris I, No 66, 1969, p. 772. No mesmo contexto, Foucault diz: «' arqueologia' [...] descrição do arquivo » .
} 
donde é necessário o seu caráter crítico. Em outras palavras, o arqueólogo faz ver o que se pode $\operatorname{ver}^{2}$.

Então, no âmbito geral da arqueologia, deparamo-nos com uma forma constante de indagar de onde falam e emergem as continuidades do pensamento, ou seja, as maneiras em que a história codificou e organizou, sob a marca de grande disciplina das Ciências Humanas, as manifestações maciças e homogêneas do espírito ou, para sermos mais fiéis ao filósofo francês, aos problemas do pensamento. Ora, o motivo de nos colocarmos de dentro da própria história do pensamento para questionar o que nos tornou possíveis, que é o que a arqueologia faz, não nos reenviando necessariamente ao passado, mas também nos situando em nosso próprio tempo, dá-se pelo fato de ser a história, encetada pelas exigências de Foucault: “o modo de ser fundamental das empiricidades, aquilo a partir de que elas são afirmadas, postas, dispostas e repartidas no espaço do saber para eventuais conhecimentos e para ciências possíveis"3.

Com efeito, é esse eventual conhecimento que a história faz surgir à guisa de uma tarefa, a partir de agora, essencialmente positiva. Impõe-nos admitir que a possibilidade de delinear o eventual, como vemos, ocorre a partir das condições de existência do que pode vir à baila como objeto de análise à história, levando em consideração o funcionamento e a transformação de um conhecimento que não se cansará de ser provisório. Isso ocorre sem dúvida, pois serão as práticas, a nosso ver, o problema real a ser enfrentado, já que se apresentam de múltiplas maneiras e acabam instituindo uma novidade de critério para o pensamento sobre a história, que consiste na forma descontínua em que a história operará ${ }^{4}$.

\footnotetext{
${ }^{2}$ São esclarecedoras as palavras de Veyne quanto à descrição: "Vê-se o método seguido: consiste em descrever, muito positivamente, o que um imperador paternal faz, o que faz um chefe-guia, e em não pressupor nada mais; em não pressupor que existe um alvo, um objeto, uma causa material (os governados eternos, a relação de produção, o Estado eterno), um tipo de conduta (a política, a despolitização). Julgar as pessoas por seus atos e eliminar os eternos fantasmas que a linguagem suscita em nós. A prática não é uma instância misteriosa, um subsolo da história, um motor oculto: é o que fazem as pessoas (a palavra significa exatamente o que diz)". (VEYNE, P. Como se escreve a história e Foucault revoluciona a história. Brasília: Editora UNB, 1998, p.248). É preciso notar, porém, um fator limitador, justamente de onde surge o punctum saliens da arqueologia: a história que demanda pela descrição, portanto, pela palavra, estará circunscrita aos limites da própria efetivação da palavra. Mas isso está para a própria condição da história: sua formação não pode mais nada além de sua visibilidade. Deleuze melhor precisou esse aspecto: "[...] cada formação histórica vê e faz ver tudo o que ela pode, em função de suas condições de visibilidade, como ela diz tudo o que ela pode em função de suas condições de enunciado". (DELEUZE, G. Foucault. Paris: Éditions de Minuit, 1986, p.66)

${ }^{3}$ FOUCAULT, M. As palavras e as coisas, p. 300 .

${ }^{4}$ Nessa direção, vale a pena mencionar o comentário de Wahl, com o qual julgamos melhor iluminar esse ponto: "A arqueologia, pois, não é nem a filosofia - tida pela cadeia de sentido, do transcendental ao sujeito -, nem a ciência - dispondo na superfície o encadeamento de seus conceitos ao pressupor a homogeneidade teórica -; a arqueologia é tarefa de positividade - as formações discursivas são dadas - e, de uma positividade que se articula não no sobrevôo de um estado, mas nas condições de operação de uma prática". (WAHL, F. Hors ou dans la philosophie? L'Archeologie du savoir, L'Usage des plaisirs, Le Souci de soi. In. Michel Foucault Philosophe: Rencontre Internationale. Paris, 9, 10, 11 janvier 1988. Paris: Seuil, 1989, p.88.)
} 
Assumindo uma tarefa crítica imprescindível à descrição arqueológica, Foucault pretende livrar-se de um jogo de noções que estão ligadas ao postulado de continuidade, voltados para a consecução dos níveis em que a visibilidade da própria história e a do pensamento pudessem se apresentar como uma história que não cessa de evoluir, ou melhor, de somar sobre si a razão de existir das coisas. No cerne dessa questão, a descontinuidade busca aquilatar as transformações específicas das práticas humanas. Ora, se é assim, faz sentido vermos que "a propósito da história, e precisamente a propósito da história do saber, ou da razão, é possível mostrar que ela não obedece ao mesmo modelo de consciência"; então, foi para tanto que "se chegou a mostrar que o tempo do saber ou do discurso não é organizado

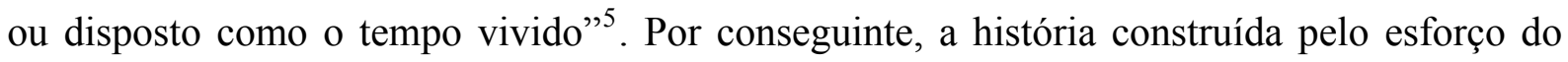
pensamento crítico terá de conceber linhas e divisórias distintas, desconexas, rompidas com uma razão fundadora de relações em que tempo e espaço não se conjugam concomitantemente.

Com isso, numa primeira instância, ficará deslocada a noção de tradição que, por sua vez, permite localizar toda novidade a partir de um sistema de coordenadas permanentes, e de dar um status a um conjunto de fenômenos constantes e idênticos. Se, por um lado, a tradição "autoriza reduzir a diferença característica de qualquer começo, para retroceder, sem interrupção, na atribuição indefinida da origem" ${ }^{6}$, por outro, a arqueologia dissipará a tradição, uma vez que é impossível dotar os registros a partir dos quais a descrição histórica emergirá de uma data inaugural.

Na mesma direção, ela questiona a noção de influência, ou melhor, afasta dela a história. A influência procura dar suporte aos fatos de transmissão ou de comunicação, quer dizer,

atribui a um processo de andamento causal (mas sem delimitação rigorosa nem definição teórica) os fenômenos de semelhança ou repetição; que liga, à distância e através do tempo - como por intermédio de um meio de propagação -, unidades definidas como indivíduos, obras, noções ou teorias ${ }^{7}$.

De certa maneira, a influência não deixa de ser o que aquilata a tradição, já que cerca o acontecimento histórico de uma importância que certamente está disposta no fato, pessoa, grupo social, enfim, em tudo o que exerce a ação direta sobre o registro. Não sem sentido, por vezes, a história tenta sobreviver graças a um nome ou a uma data. Somamos a isso, em

\footnotetext{
${ }^{5}$ FOUCAULT, M. Michel Foucault explique son dernier livre. Dits et Écrits I, No 66, 1969, p.774.

${ }^{6}$ FOUCAULT, M. A arqueologia do saber, p.23.

${ }^{7}$ Ibidem, p.24.
} 
seguida, os esforços pela superação da noção de desenvolvimento, o qual permite descrever uma sucessão de acontecimentos como a manifestação de um único e mesmo princípio organizador, em que o desenvolvimento estaria para a evolução da história. Negar, contudo essa perspectiva, é conceber a vitalidade de relações de forças que, fora de uma homogeneidade na qual as experiências no tempo não podem ser as mesmas, conduz, então, a uma inevitável fragmentação de nossas experiências em relação ao acontecimento passado e ao que ainda está por vir.

Podemos dizer, de maneira final, que disto decorre o exercício de problematização histórica que contornará o ideário de mentalidade ou o espírito de uma época. Os fatos, as prática e os saberes não coexistem porque os homens foram preparados por algo que os movessem em determinada direção. Com isso, em nosso juízo, a arqueologia põe em prova o que permitiu "estabelecer entre os fenômenos simultâneos e sucessivos de uma determinada época uma comunidade de sentido, de ligações simbólicas, um jogo de semelhança e de espelho - ou que fazem surgir, como princípio de unidade e de explicação, a soberania de uma consciência coletiva" ${ }^{\sharp}$. Claro, para nós, Foucault aponta para as tentativas englobantes que, de uma só vez, desejam arranjar o cenário para os acontecimentos, idéias e valores que não podem ser limitados de uma maneira simplista ou codificados somente por estarem circunscritos a uma época, que seria o caso de uma Weltanschauung.

Tradição, influência, desenvolvimento e mentalidade são noções que repousariam à sombra dos postulados de uma continuidade histórica, isto é, daquela perspectiva que se volta notadamente para o tempo. E, ao seu modo, a intervenção da arqueologia suscitará uma nova análise e tais noções, agora postas em questionamento a partir de seu próprio surgimento, serão desalojadas de suas funções e cederão lugar a outras. A questão é, que na arqueologia, a história deixa de assumir um papel estritamente temporal e torna-se, antes de mais nada, espacial, espécie de cartografia no sentido de uma história-geografia. Quer dizer, o que vemos assumir de vez força incontornável é a perspectiva da história serial, pois nenhuma formação

\footnotetext{
${ }^{8}$ Ibidem, Id. Para não ignorarmos a importância da descontinuidade referente à abordagem que será dada aos objetos da história crítica do pensamento, ponderamos que é relevante a abordagem que Dosse desfere: "A descontinuidade permite fixar os limites do objeto de estudo, e descrevê-lo a partir de seus limiares, de seus pontos de ruptura. Ela é, enfim, um meio de construir, não mais uma história restringida em torno de um centro, uma história global, mas o que se poderia chamar uma história geral, que se define, pelo contrário, como o espaço de uma dispersão". (DOSSE, F. História do Estruturalismo. V.2. O canto do cisne, de 1967 a nossos dias. Campinas: Editora da Unicamp, 1994, p. 270). De fato, quando sustentamos que o arqueólogo faz ver somente o que se pode ver e que isso se dá pela descrição histórica que ele constrói, é preciso deixar claro que a dispersão se coloca aí, justamente pelo fato de não se buscar uma única verdade, mas de fazer emergir diferentes práticas que possam estar relacionadas ao objeto histórico. Não é difícil vermos a riqueza dos campos historiados por Foucault fazendo sentido à subjetividade, ou seja, a busca por práticas múltiplas com o intuito de problematizar o caráter pluridimensional e heterotópico de nossa constituição em movimento.
} 
passa a fornecer modelo para outra. Ora, já que a série diz respeito à abrangência espacial, um determinado enunciado poderá ocupar um espaço concreto e privilegiado. Assim, o enunciado e, por conseguinte, o discurso que a história opera a respeito de qualquer descrição, fazem-se existir senão porque há uma linguagem que efetiva o seu modo de ser, vinculada aos efeitos que produz numa área qualquer ${ }^{9}$. Com isto, julgamos que Foucault, mesmo que não tenha sido esta a sua intenção, forneceu-nos condições para buscarmos, na temática da subjetividade, uma produção de disjunções de experiências, postulada pela capacidade atual do acontecimento, com as quais somos autorizados a fugir das restrições impostas por qualquer tipo de modelo que se pretende como agenciamento de área irrefutável. Teríamos, assim, campos de subjetividades como inscrição transitória das experiências numa série de acontecimentos.

Visto sob o ângulo dessa produção de descontinuidade, deparamo-nos com a abertura de um novo campo de análise cujo processo do reconhecimento histórico não mais se encontra nos termos de uma verdade que estaria no objeto ou no sujeito, mas, de um modo mais complexo, na abrangência e no entrelaçamento de um conjunto de discursos. Devemos, contudo, entender como é possível tal dimensão. Nas palavras de Foucault:

trata-se de agora em diante de saber como um indivíduo, um nome pode ser o suporte de um elemento ou grupo de elementos que, se integrando na coerência do discurso ou da rede indefinida das formas, vêm apagar ou ao menos tornar vazio e inútil este nome, esta individualidade com a qual ele porta até um certo ponto, durante um certo tempo e por certa relação, uma marca ${ }^{10}$.

Em outros termos, a arqueologia provoca uma inevitável ruptura na forma da descrição histórica, pois instaura, por meio da ação do enunciado, a impossibilidade de fixar a própria história e o próprio pensamento. Ora, ao conceber as representações da história e do pensamento a partir de constantes fraturas, cisões e descontinuidade, o que se justifica pelo

\footnotetext{
${ }^{9}$ Aqui seguimos de perto a proposta interpretativa de Deleuze quanto ao espaço. Para esse autor, o "enunciado é o objeto específico segundo o qual ele se conserva, se transmite ou se repete". Para tanto, "o enunciado se conserva em si, em seu espaço, e vive na medida em que esse espaço dura ou é reconstituído". Assim, em volta de um enunciado que emerge na descrição arqueológica, encontraremos um espaço colateral, a que outros enunciados se congregam, fazendo parte de um mesmo grupo, no intuito de localizar uma determinada formação histórica; um espaço correlativo, que permite ao enunciado uma constituição a partir de posições variadas, onde não é mais possível fundar um discurso, um fato, uma prática histórica a partir de um sujeito; finalmente, um espaço complementar: gênero extrínseco à interioridade de qualquer discurso, pois se relaciona com as formações não discursivas, isto é, instituições, acontecimentos políticos, práticas e processos econômicos. A história crítica do pensamento, nessa perspectiva, indaga pelo espaço em que se instauraram os acontecimentos, as regras, as normas, os ditos, as práticas, as leis, as subjetividades, enfim, tudo o que se tornou histórico. Nisso podemos dizer que a indagação fundamental da arqueologia é: como isto ou aquilo (práticas) tornaram-se possíveis? (Cf. DELEUZE, G. Foucault. Paris: Éditions de Minuit, 1986, p.14-20).

${ }^{10}$ FOUCAULT, M. Sur les façons d'écrire l'histoire. Dits et Écrits I, No 48, 1967, p.596.
} 
próprio fato de não haver uma continuação entre uma pesquisa elaborada e outra, cremos que Foucault quer afirmar para nós e em nós o caráter provisório que a história abriga.

Dessa maneira, a descrição arqueológica não deixará de ser uma operação instrumentalizada pelo trabalho do historiador, numa tarefa infinita, que não cessa de se especificar e exercitar, quer dizer, de aprofundar cada vez mais as fissuras inerentes ao pensamento que surge no contexto arqueológico. Temos aí, e nas palavras de Foucault, o persistente "deslocamento do descontínuo" como "elemento positivo que determina seu objeto e valida sua análise" ${ }^{\prime 1}$. Com isso, vem à tona a possibilidade de pensarmos em níveis arqueológicos, já que o trabalho de análise a ser desempenhado pela palavra que descreve não é mais um vazio puro e uniforme a separar de um único e mesmo espaço duas figuras positivas - o que se tornará descritível -; assim, a história toma uma forma e uma função diferentes segundo o domínio e o nível em que é delimitada. Eis, tão logo isso seja possível, uma pletora de problematizações que se encontram e se dão em "recortes", "limites", "desníveis", “defasagens", “especificidades cronológicas” e "formas singulares de permanência" 12 - termos tão distintos que se referem à rarefação que a arqueologia executa, isto é, os fatos históricos "são raros, não estão instalados na plenitude da razão, há um vazio em torno deles para outros fatos que o nosso saber nem imagina; pois o que é poderia ser diferente" ${ }^{\prime 3}$. Por esse motivo, é plausível nos dirigirmos de múltiplas formas ao que o pensamento permite alcançar e, então, acenarmos para que o olhar da descrição capte ali o que quer e possa fazer falar. Numa idéia,

\footnotetext{
a arqueologia, dirigindo-se ao espaço geral do saber, às suas configurações e ao modo de ser das coisas que aí aparecem, define sistemas de simultaneidade, assim como a série de mutações necessárias e suficientes para circunscrever o limiar de uma positividade nova $^{14}$.
}

É forçoso pensarmos que, por operar em cada investigação da história crítica do pensamento de uma maneira variada, subsume-se à arqueologia o seu caráter provisório. Ficam abalados os critérios formalizadores e hermenêuticos que desejam encetar a verdade histórica. Decorre disso o fato de, no limite, podermos dizer que é para efeito de diagnóstico que a história opera a sua investigação. Ademais, sob o argumento de Foucault, "se a filosofia é memória ou retorno da origem, o que faço não pode, de modo algum, ser considerado como

\footnotetext{
${ }^{11}$ FOUCAULT, M. A arqueologia do saber, p.11.

12 Ibidem, Id.

${ }^{13}$ VEYNE, P. Como se escreve a história e Foucault revoluciona a história. Brasília: Editora UNB, 1998, p.239.

${ }^{14}$ FOUCAULT, M. As palavras e as coisas. Prefácio, p. XX.
} 
filosofia, e se a história do pensamento consiste em tornar a dar vida a figuras semi-apagadas, o que faço não é, tampouco, história" ${ }^{15}$.

Ora, tudo o que surgir da arqueologia não quer ser verdadeiro, porém, já é interpretação que se impõe sob o registro de um conhecimento que não é natural. Em outros termos, subjaz à interpretação uma apropriação que se forja no contexto de uma "relação de luta, de dominação, de subserviência”, pois “o conhecimento só pode ser uma violação das coisas a conhecer e não percepção, reconhecimento, identificação delas ou com elas" "16. É nesta medida que a arqueologia é procedimento que se afirma na via de uma Erfindung invenção - como chave de ruptura com qualquer tipo de origem, inclusive a que sustentaria que o conhecimento está inscrito na natureza humana. Quais seriam, portanto, as implicâncias para nós no instante que passássemos a conhecer as medidas e valores históricos de nossa constituição, correlacionadas a um jogo violentador no qual fomos e somos subjugados?

Para nós, no centro da discussão que se estabelece a partir da continuidade e descontinuidade, especialmente uma salta aos olhos: o fato de que a descontinuidade se abre ao pensamento do que não é o mesmo, repelindo o decalque que carrega a filigrana do modo de objetivação ou subjetivação correspondente a uma essência ou fundação. Para tanto, serão convocadas as condições do impensado. Assim, podemos pensar o outro no tempo de nosso próprio pensamento, mas sob condições diferentes postas no espaço histórico: buscamos, forçosamente, por sua contingência. Destarte, a descontinuidade é infatigável ao se impor às formas de saberes que tentam "proteger, contra todas as descentralizações, a soberania do sujeito" ${ }^{17}$. Aliás, é necessário ressaltar para o bem do argumento que

a história contínua é o correlato indispensável à função fundadora do sujeito: a garantia de que tudo que lhe escapou poderá ser devolvido; a certeza de que o tempo nada dispensará sem reconstituí-lo em uma unidade recomposta; a promessa de que o sujeito poderá, um dia - sob a forma da consciência histórica -, se apropriar, novamente, de todas essas coisas mantidas à distância pela diferença, restaurar seu domínio sobre elas e encontrar o que se pode chamar sua morada ${ }^{18}$.

Assim, para além desse nível, julgamos que a arqueologia anuncia a dissolução das marcas que um pretenso sujeito intentou deixar na história. Aliás, tais marcas são mais superficiais do que se imagina, pois já não nos encontramos no registro em que a história, respaldando-se no sujeito, criou e sustentou a auto-ilusão de que nele justificaríamos a nossa razão de existir.

\footnotetext{
${ }^{15}$ FOUCAULT, M. A arqueologia do saber, p.233.

${ }^{16}$ FOUCAULT, M. La vérité et les formes juridiques. Dits et Écrits I 1953-1975, № 139, 1974, p.1414.

${ }^{17}$ FOUCAULT, M. A arqueologia do saber, p.15.

${ }^{18}$ Ibidem, p.14-15.
} 
A nós nos parece que Foucault faz surgir no horizonte uma ordem diferente acerca do entendimento da história e de seus efeitos. E na proporção que podemos conceber essa perspectiva, uma certa descontinuidade no estatuto geral da descrição arqueológica irá se estabelecer, elucidando a ordem que vem do exterior. Isto significa ter em mente que é o recorte operado por quem anuncia o fato, o problema, enfim, o circunscrito a um espaço aquilatado pela linguagem, que permitirá a organização e fixação de uma determinada ordem ao discurso. Faz sentido, nesses termos, conceber que "todo limite não é mais talvez que um corte arbitrário num conjunto indefinidamente móvel" ${ }^{19}$, quer dizer, enquadre que não pode alcançar a totalidade do que se move no subterrâneo da história. Certamente é assim, uma vez que a linguagem não esgota a própria história. Vista sob tal prisma, a arqueologia em suas análises formula o problema "das relações do pensamento com a cultura: como sucede que um pensamento tenha um lugar no espaço no mundo, que aí se encontre como que uma origem, e que não cesse, aqui e ali, de começar sempre de novo"20.

Mesmo assim, a origem não deixa de ser traçada, todavia, no próprio limite sobre o qual a análise se debruça; não pode ser mais dada, melhor ainda dizer, põe-se além de qualquer significante agenciador de um significado correspondente. Então teremos, inevitavelmente, um movimento peculiar no tratamento da análise. Se as relações do limite, da ordem que é posta na descrição arqueológica, procedem da própria cultura - pensamento que ocupa um lugar no espaço do mundo - o descontínuo, por conseguinte, será o "fato de que em alguns anos, por vezes, uma cultura deixa de pensar como fizera até então e se põe a pensar outra coisa e de outro modo" ${ }^{21}$. Eis de onde tal ordem externa dá acesso a uma erosão que o pensamento não deixa de exercer sobre o próprio pensamento. Nesse aspecto, nada mais peremptório do que afirmarmos, por intermédio das palavras do filósofo francês, sem parcimônias, que vemos

[...] desenhar-se, assim, um certo número de desligamentos e de articulações. Não se pode mais dizer que uma descoberta, a formulação de um princípio geral, ou a definição de um projeto, inaugura - e de forma maciça - uma fase nova na história do discurso. Não se deve mais procurar o ponto de origem absoluta, ou de revolução total, a partir do qual tudo se organiza, tudo se torna possível e necessário, tudo se extingue para recomeçar. Temos que tratar de acontecimentos de tipos e de níveis diferentes, tomados em tramas históricas distintas; uma homogeneidade enunciativa que se instaura não implica de modo algum que, de agora em diante e por décadas ou séculos, os homens vão dizer e pensar a mesma coisa; não implica, tampouco, a definição,

\footnotetext{
${ }^{19}$ FOUCAULT, M. As Palavras e as Coisas, p.69.

${ }^{20}$ Ibidem, Id.

${ }^{21}$ Ibidem, Id.
} 
explícita ou não, de um certo número de princípios de que todo o resto resultaria como conseqüência ${ }^{22}$.

Posto isto, podemos dizer que a ordem exercida sobre um domínio qualquer trará à evidência um quadro geral de análise, que, situado no recorte estabelecido, fundamentará o que Foucault designou de "crítica do documento". Este não é mais o dado silencioso ou explícito, a soma ininterrupta de acontecimentos resguardados sob uma unidade qualquer, nem é a materialidade extensiva e facilmente localizável nas ruínas do tempo, mas o documento se tornou, pelo viés arqueológico, o monumento histórico. Contudo a tarefa de análise não busca, numa prova concreta, o que podemos simplesmente ler, como se fosse possível, para efeito de tradução, nos apossarmos conscientemente do acontecimento histórico em registro perene. Por ser produzido no exercício da arqueologia, o documento é o quadro que delimita a esfera do que desejamos anunciar. Nos termos do filósofo da história crítica: “o documento, pois, não é mais, para a história, essa matéria inerte através da qual ela tenta reconstituir o que os homens fizeram ou disseram, o que é passado e o que deixa apenas rastros; ela procura definir, no próprio tecido documental, unidades, conjuntos, séries, relações" 23 .

Levando em consideração esse delineamento, não podemos encontrar sob a noção de documento uma unidade rígida capaz de justificar a história. Cumpre notar que o documento pressupõe um rompimento com a série de materialidade que, durante muito tempo, foi utilizada pela sociedade para amalgamar uma espécie de identidade histórica. O que significa dizer que nem pretensa unidade atribuída a uma obra qualquer, antes tomada como documento concluso, pode, agora, ser tomada como ponto de apoio para a descrição arqueológica de pensamento e dos acontecimentos. Pesam, nesse sentido, os termos a confirmar que

em nossos dias, a história é o que transforma os documentos em monumentos e que desdobra, onde se decifravam rastros deixados pelos homens, onde se tentava reconhecer em profundidade o que tinham sido, uma massa de elementos que devem ser isolados, agrupados, tornados pertinentes, inter-relacionados, organizados em conjuntos. Havia um tempo em que a arqueologia, como disciplina dos monumentos mudos, dos rastros inertes, dos objetos sem contexto e das coisas deixadas pelo

\footnotetext{
22 FOUCAULT, M. A arqueologia do saber, p.167. A nosso ver, Deleuze ilumina muito bem essa questão ao comentar que "a tarefa da arqueologia é, antes de mais nada, a de descobrir uma verdadeira forma de expressão que não se pode confundir com nenhuma das unidades lingüísticas, quaisquer que sejam, significante, palavra, frase, ato da linguagem". Para tanto, é preciso levar em consideração que o enunciado que a arqueologia descreve não é algo velado, escondido, cuja revelação se daria pela história. "O enunciado jamais está escondido [...] ele está lá, diz tudo, desde que se atente às suas condições”. (DELEUZE, G. Foucault. Paris: Éditions de Minuit, 1986, p.59-60.)

${ }^{23}$ Ibidem, p.07.
} 
passado, se voltava para a história e só tomava sentido pelo restabelecimento de um discurso histórico; poderíamos dizer, jogando um pouco com as palavras, que a história, em nossos dias, se volta para a arqueologia - para a descrição intrínseca do monumento ${ }^{24}$.

Então, a ordem sobre a qual a descrição arqueológica está operando passa a questionar a unidade do documento por intermédio de uma ação deliberativa do recorte estabelecido para e pela análise. O filósofo renuncia, desde já, à possibilidade de vasculhar no documento o acontecimento verdadeiro; encontrar o fio que expõe o estopim do grande feito (ou da causa) deflagradora de qualquer começo e episódio, de qualquer origem secreta e velada. Por não ser uma síntese acabada da história, irá se tornar o efeito de uma construção, cujas regras devem ser conhecidas e cujas justificativas devem ser controladas. Efeito e causa da própria tarefa arqueológica, com o documento, enfim, "não se busca, sob o que está manifesto, a conversa semi-silenciosa de um outro discurso: deve-se mostrar porque não poderia ser outro, como exclui qualquer outro, como ocupa, no meio de outros e relacionado a ele, um lugar que nenhum outro poderia ocupar" ${ }^{25}$. Mas aí deparamo-nos com uma outra dimensão da ordem arqueológica: a sua interioridade.

Ora, se a descontinuidade aquilata a história referenciando-a, notadamente, pelo espaço, a começar pelo espaço do discurso de onde ela falará, numa outra direção, pelo fato de nenhuma investigação do pensamento humano ser dissociada de uma maneira absoluta de sua época, a descontinuidade não será total. O pensamento que fala o fará, forçosa e inevitavelmente, a partir de relações teóricas e práticas que não são independentes de o que se passa em sua época, logo, num eixo temporal. Então, podemos dizer, a descontinuidade opera

\footnotetext{
${ }^{24}$ Ibidem. p.08. De nossa parte, sustentamos que o documento é o princípio histórico que se coloca, agora, fora da perspectiva da busca de um "sentido" ou de uma "razão" que pudesse mover a história. Ao procurar as múltiplas formas conceituais e práticas que operam no pensamento, o documento revela-se em diferentes estados sob diferentes saberes. Mas é preciso atentar para o seguinte aspecto: a interpretação que oferece a sua prospecção ao documento não tem por pretensão garantir uma verdade absoluta. No entanto, não quer, desta maneira, assumir uma postura niilista, como pretende Descombes, mas quer simplesmente dispersar a história: o documento sempre diz mais além do que sobre ele já foi dito. Segundo o autor, Foucault "não ignora que toda interpretação é polêmica: propor uma interpretação é declarar a guerra a uma interpretação vizinha; com efeito, toda interpretação de um fato pretende dar o sentido desse fato; mas os fatos não têm por eles mesmos nenhum sentido, interpretação somente o encontra fazendo falar, de maneira que a interpretação de um fato é sempre, na realidade, a interpretação de uma primeira interpretação disfarçada em fato bruto e positivo. Essa conviç̧ão segundo a qual os fatos não significam nada define o niilismo da geração de Foucault" (DESCOMBES, V. Le Même et L'autre - quarente-cinq ans de Philosophie Française (1933-1978). Paris: Les Éditions Minuit, 1979, p.138). A abordagem deste intérprete é instrutiva e relevante no sentido de considerar a relação, de fato, não teleológica que existe na interpretação. Todavia discordamos que a postura interpretativa tal qual ele concebe acerca da obra de Foucault revela um niilismo de geração. Ora, a questão é justamente a não teleologia que se pressente com a descontinuidade. Com isso, no entanto, o documento não funda um propósito unificador, como já dissemos; porém pulveriza e dispersa a trama histórica: por exemplo, a loucura é fruto de uma dispersão de acontecimentos, práticas, normas, regras.

${ }^{25}$ Ibidem, p. 09.
} 
com o seu duplo na esfera do tempo, ou seja, essa porção contínua de onde cada pensamento, a seu modo, ganha o estatuto de ser histórico.

Esse nível da ordem, por operar no âmbito interno da história, isto é, num saber de múltiplas configurações sobre o qual a arqueologia tenta escrutinar, tornar visível uma de suas facetas pela descrição, repousa capilarmente em toda cultura. "Assim, em toda cultura”, deixa transparecer Foucault, "entre o uso do que se poderia chamar os códigos ordenadores e as reflexões sobre a ordem, há a experiência nua da ordem e de seus modos de ser" ${ }^{26}$.

Certamente que se impõe aqui um problema. Se tomarmos a ordem do tempo em que o saber se configura e por onde se fala, a arqueologia seria uma promessa natimorta. Além de não trazer ganho teórico às análises que intentam pensar como as coisas se tornaram possíveis, faria cumprir, entretanto, somente a história da ordem do mesmo. Mas é justamente nesse entroncamento que reside a problemática da história crítica do pensamento e da arqueologia que desponta como um de seus procedimentos. De dentro da ordem histórica, ao recortá-la pela ruptura de um discurso que delimita a sua ação e visibilidade, surge um espaço que é o da história do outro. Então será de dentro da própria totalização do tempo que as configurações espaciais que descrevem uma série de acontecimentos, nessa ordem exterior, procurará dissolver o próprio tempo. Mas, para nós, tal fato não ocorre sem que se coloque o enunciado em jogo.

Com efeito, poderíamos dizer, agora, que "duas exigências simultâneas na rede arqueológica" ${ }^{27}$ surgem em cena; trata-se de duas exigências complementares, portanto, irredutíveis: a descontinuidade e a continuidade. Ambas operam no domínio do enunciado, que é o objeto próprio da arqueologia. Assumir tal afirmação, contudo, representa analisar as conseqüências advindas do próprio tratamento dispensado ao enunciado, no que diz respeito à rede arqueológica, e sua configuração enquanto noção primordial de análise.

O que é posto em questão, assim, é uma configuração que desenha a área de um campo histórico do pensamento empírico, uma vez que se trata de definir as transformações ocorridas numa determinada ordem, por intermédio de um espaço descritivo ou narrativo, no qual a pesquisa arqueológica se vê, frente a frente, com o seu instrumento e objeto. Por seu turno, o objeto não poderá ser um dado bruto: é plasmado pela ação do enunciado ${ }^{28}$. Mas a

\footnotetext{
${ }^{26}$ FOUCAULT, M. As Palavras e as Coisas, Prefácio, p. XVIII.

${ }^{27}$ Ibidem, p.208.

28 De extrema valia aqui são os comentários de Deleuze: "Um enunciado sempre representa uma emissão de singularidades, de pontos singulares que se distribuem em um espaço correspondente. As formações e transformações desses espaços colocam, eles mesmos, problemas topológicos que se exprimem muito mal em termos de criação, começo ou fundamento. [...] o enunciado não remete a nenhum cogito, nem a sujeito transcendental que o tornasse possível, nem a um Eu (Moi) que o pronunciaria pela primeira vez (ou o
} 
sua ação jamais se dá por homogeneidade. Aliás, não se trata de uma síntese acabada: o enunciado ocupa o lugar de função objeto ou de sujeito em constante deslocamento. Uma vez que podemos colocar ambos em suspeição, o enunciado tornou-se o espaço a partir de onde as múltiplas posições que objeto e sujeito podem ocupar se configuram. Tal ocorrência se dá pelo fato de o enunciado abranger um plano duplo: numa dimensão, o plano discursivo; e, em outra, o não discursivo.

No plano discursivo, o enunciado traz em seu bojo uma unidade de elementos capaz de revelar "o jogo das regras que definem as transformações desses diferentes objetos" 29 sobre os quais a arqueologia se debruça. Objetos que, nas mesmas palavras de Foucault, "são recortados por medidas de discriminação e de repressão, objetos que se diferenciam na prática cotidiana, na jurisprudência, na casuística religiosa, nos diagnósticos dos médicos, objetos que são limitados por códigos ou receitas de medicação, de tratamento de cuidados" 30 . Ora, nesses termos, para descrevermos a emergência dos objetos, o aparecimento e distribuição de uma norma ou prática, para fazermos a ruptura histórica, portanto, provocar a emersão do documento, um duplo movimento há de ser concebido: de um lado, os enunciados serão o instrumento de análise; de outro, serão o próprio objeto de análise, o que confere à filosofia de Foucault um caráter inovador e peculiar, porque nenhum objeto será puro em sua apreensão e dado de forma imediata ao pensamento.

Posto desse modo, o enunciado não se limitará e muito menos será os seus elementos gramaticais ou sua ligação a uma estrutura lingüística qualquer. Efeito de uma etapa de descrição arqueológica a respeito das ciências humanas, podemos encontrar facilmente, na obra As palavras e as coisas, a modificação do ser da linguagem, no qual o sistema de signo que orbitava ao redor da linguagem se transmutara. Dito de outro modo, a relação espacial da linguagem não se fixa no tempo. Se, na época clássica, a linguagem era um caso particular de representação, para nós ela se tornou um caso de significação. "Desde logo, tudo pode tornarse discurso" 31 . Conseqüentemente, presa na sua própria incapacidade de transpor o nível da linguagem, "os critérios que permitem definir a identidade de uma proposição, distinguir várias delas sob a unidade de uma formulação, caracterizar sua autonomia ou sua propriedade de ser completa, não servem para descrever a unidade singular de um enunciado"32. O enunciado não se atém ao perpetuum mobile da linguagem. Por extensão, será menos a

recomeçaria), nem o recuperaria. Há "lugares" ("places") de sujeito para cada enunciado, aliás muito variáveis". DELEUZE, G. Foucault. Paris: Éditions de Minuit, 1986, p.13 e 14.

${ }^{29}$ FOUCAULT, M. A arqueologia do saber, p.37.

${ }^{30}$ Ibidem, Id.

${ }^{31}$ FOUCAULT, M. As Palavras e as Coisas, p.138.

${ }^{32}$ FOUCAULT, M. A arqueologia do saber, p. 92. 
produção de um efeito lógico-formal a parte coerente de um sistema de pensamento. Ele se sobrepõe, no entanto, às regras de uma linguagem, ao jogo lógico da consciência, a um fato que se quer crer como verdadeiro. Certamente, por se dar também na operação da ordem interna de um saber, dele escapa a pretensão de esgotar pela linguagem o que pode estar em si mesmo no enunciado. Antes mesmo que seja possível, alcançado por uma linguagem que tenta lhe dar certos contornos, ele será tocado por uma voz inexponível em seu alcance, um fala-se anônimo (on parle anonyme), do qual não será mais possível saber de todos os seus efeitos, já que ele também se rarefaz.

Então, que fique claro, o enunciado está no plano da função: cumpre um domínio, fazendo circular sobre si regras e efeitos; ambos realizados pelo próprio enunciado. Ele poderá ser repetido, recalculado, reeditado por um saber qualquer, embora a existência de sua enunciação sempre ocorra de maneira única, singular, inconfundível. Eis aí porque a prática da ação pastoral - confiteor [eu confesso] - pode ser acampada, dimensionada, reutilizada, depurada e reaplicada nas múltiplas alcovas de confissão que pairam sobre a prática da medicina: o doente confessa a sua doença; na prática da punição: o réu confessa o crime; na prática da política: o discurso confessa a intenção; na prática da sexualidade: o desejo confessa o sexo. De sorte que, em vez de ser uma estrutura ou unidade, o enunciado opera como uma "função que cruza um domínio de estruturas e de unidade possíveis e que faz com que apareçam, com conteúdos concretos, no tempo e no espaço"33.

Dito deste modo, transparece à arqueologia que sua tarefa não pode ser achar o fundo do acontecimento que instaurou o efeito. Uma vez adstrita ao enunciado, sua análise operará sobre um

\footnotetext{
"referencial" que não é constituído de "coisas", de "fatos", de "realidades", ou de "seres", mas de leis de possibilidades, de regras de existência para os objetos que aí se encontram nomeados, designados ou descritos, para as relações que aí se encontram afirmadas ou negadas. O referencial do enunciado forma o lugar, a condição, o campo de emergência, a instância de diferenciação dos indivíduos ou dos objetos, dos estados de coisas e das relações que são postas em jogos pelo próprio enunciado ${ }^{34}$.
}

A partir daí, vemos que surge, no delineamento argumentativo do filósofo da descontinuidade, um caráter essencialmente novo de análise. Assim, depositamos no nível enunciativo menos uma possibilidade de análise formal, de investigação semântica, que de uma análise das

\footnotetext{
${ }^{33}$ FOUCAULT, M. A arqueologia do saber, p.99.

${ }^{34}$ Ibidem, p.104.
} 
"relações entre enunciado e os espaços de diferenciação, em que ele mesmo faz aparecer as diferenças",35.

Ponto não despiciendo, no entanto, é o de assinalar que não buscamos o autor fundador de um enunciado. Se a história sempre procurou por seus autores e sujeitos, assim como também o efeito da linguagem materializada nos manuais históricos ou na própria literatura; cumpre saber que, no nível arqueológico, o enunciado oferece à dimensão da descrição um vazio que pode ser preenchido pela própria descrição. Não mais do que isto, pois ela sempre se esvazia, já que, ao descrever o pensamento, a história tenta inutilmente preencher o seu vazio que lhe escapa, porque ele se duplicará ainda mais, ao passo que, na extensão do dito, encontra-se o não dito. Logo o enunciado “é um lugar determinado e vazio que pode ser efetivamente ocupado por indivíduos diferentes" ${ }^{\text {"36. }}$.

Justificamos, dessa forma, a concepção resiliente da história: campos de direções movediças e quebradiças desdobrados na multiplicidade do jogo enunciativo. Ora, como o enunciado acaba sendo um tipo de virtualidade sem rosto, pulsará de modo distinto em sua perspectiva não discursiva, que compreende "as instituições, acontecimentos políticos, práticas e processos econômicos" 37 , enfim, a efetivação concreta de onde o discurso sobre o louco pode ser dito: hospício, asilo; de onde o discurso sobre o doente é validado: hospital, sala médica; de onde o anormal e o transgressor receberão a sua disciplina: prisão, escola correcional; de onde o sexo será moralizado e teleologizado: normas sexuais; enfim, de onde a fala é institucionalizada. Sob esse cenário, "um enunciado tem sempre margens povoadas de outros enunciados" ${ }^{38}$, ou seja, não existe discurso deslocado ou isolado de seu aspecto não discursivo, quer dizer, prático. Decorre dessa elaboração que todos os discursos que se voltam para qualquer espécie de saber, práticas ou efeitos têm, como fios de uma rede, conexões com outros discursos. É dessa maneira que não haverá uma medicina clínica voltada para a loucura e demência em sua pureza, uma psiquiatria, como não se pode sustentar que há um poder, uma sexualidade. Nessa esfera, como em quaisquer outras, podemos encontrar camadas, sedimentações, ou até mesmo fragmentos de textos jurídicos, apropriações instrumentalizadas

\footnotetext{
${ }^{35}$ Ibidem, p. 105.

${ }^{36}$ Ibidem, p.109. Sem dúvida, podemos ver nisto a atualização de um instrumento de crítica voltado para o sentido de um tipo de subjetividade que está longe, para nos colocarmos ao lado de Honneth, da "suposição de uma formação harmoniosa do eu (moi)" (HONNETH, A. Foucault et Adorno: deux formes d'une critique de la modernité. In. Critique - Michel Foucault du monde entier, No 471-472, 1986, p.813). A linha de coincidência entre o enunciado e o seu lugar é tão tênue que marca a passagem de um si para um outro imperceptivelmente. Concebido assim, o sujeito está sempre condenado a se desvanecer; isso ocorre, pois está aberto às séries enunciativas que não são simplesmente sucessões fechadas.

${ }^{37}$ Ibidem, p. 186.

${ }^{38}$ Ibidem, p. 112 .
} 
de conceitos filosóficos, pegadas literárias, vestígios de decisões políticas, efeito de opiniões populares e bem datadas, ou seja, uma multiplicidade de enunciados que compõe o segmento enunciativo e não enunciativo daquilo de que se trata. Subtraímos desse campo a possibilidade de questionarmos o registro significante da relação objeto-sujeito e, no que concerne à subjetividade, vemos que o sujeito não é mesmo possível de ser concebido por interioridade ou por enunciação unívoca, sob o domínio da consciência, por exemplo. Se qualquer expressão da história lança mão de uma linguagem para enunciá-la, se essa mesma linguagem também não é pura, mas é ruptura derivada e elaborada pelo enunciante e enunciado, então a história também deixa de existir. O que está circunscrito ao discurso se tornará desvanecido.

Assim, a visibilidade do enunciado, como também de tudo o que o arquivo carrega em potencial à ação da materialidade histórica, fica dependente de uma linguagem que não pode auferir a sua totalidade. Eis uma trama que impõe ao pensamento um limite intransponível: na mesma dimensão em que dependemos da linguagem para aquilatar as formas do pensamento, por sua vez, este, que ocorre à guisa do plano do enunciado, não poderá esgotar-se a si mesmo, menos ainda, dizer o que ele é - saberá somente de seus efeitos, donde a arqueologia é, necessariamente, um procedimento que traz para a história das condições dos enunciados discursivos e não discursivos os cenários dos jogos de forças. Como se isto não bastasse, precisamos levar em consideração que
a materialidade desempenha, no enunciado, um papel muito mais importante: não é simplesmente princípio de variação, modificação dos critérios de reconhecimento, ou determinação de subconjuntos lingüísticos. Ela é constitutiva do próprio enunciado: o enunciado precisa ter uma substância, um suporte, um lugar e uma data. Quando esses requisitos se modificam, ele próprio muda de identidade ${ }^{39}$.

Mas aí esgueira-se entre a forma discursiva e a materialidade do anúncio, ininterruptamente, o ser bruto do enunciado: o "discurso não-discursivo" 40 .

Condizente a isto, entretanto, não se trata de encontrar uma ordem interna, como se houvesse a possibilidade de determinar a primazia de uma manifestação enunciativa sobre a outra. No horizonte da arqueologia, como aponta Foucault, há "um emaranhado de interpositividades cujos limites e pontos de cruzamentos não podem ser fixados de imediato" 41 . Equivale a dizer que, entre uma prática qualquer que emerge de um discurso, repousa um outro discurso que se configurou numa prática qualquer e assim sucessivamente.

\footnotetext{
${ }^{39}$ Ibidem, p.116.

${ }^{40}$ FOUCAULT, M. As Palavras e as Coisas, p.167.

${ }^{41}$ FOUCAULT, M. A arqueologia do saber, p.183.
} 
Para nós, os domínios não discursivos são conspurcados. A implicância disto é que, desta concepção, emerge para o pensamento uma tarefa de análise que aproxima o discurso de um certo número de práticas, e vice-versa. Portanto, levando em consideração o sentido argumentativo tecido pelo próprio cenário da arqueologia, de uma maneira inconteste, nos vemos diante da tarefa infinita da interpretação, pois

qualquer enunciado se encontra assim especificado: não há enunciado geral, enunciado livre neutro e independente; mas sempre um enunciado fazendo parte de uma série ou de um conjunto, desempenhando um papel no meio dos outros, neles se apoiando e deles se distinguindo: ele se integra sempre em um jogo enunciativo, onde tem sua participação, por ligeira e ínfima que seja ${ }^{42}$.

Desponta, numa reposição incansável, o tema da descontinuidade. A descrição anunciativa, tarefa primordial da arqueologia, dá-se no campo cuja circunscrição ela opera. Por não atingir o fundo do sentido único e verdadeiro do qual a história sempre escapa, a cada tomada de descrição do enunciado, vemos instaurar uma história crítica que nunca será a mesma - daí sucessão infinita de rupturas. Imbricado a isto, a cada instante em que se volta para um enunciado, a história será apreendida diferentemente, pois será efeito de sua enunciação. Por conseguinte, repousa, antes da história e em seu conteúdo, a espessura da própria palavra, que faz de tudo uma figura frágil a depender da "carência das palavras que são menos numerosas que as coisas por elas designadas" ${ }^{\text {43 }}$ : implacável disjunção entre o que se vê e o que se anuncia.

Mas não estaríamos, assim, argumentando que tudo, afinal, estaria simplificado na linguagem? Longe de nós, pois ela não opera na perspectiva da síntese; ao contrário, retira do seu plano a sua estabilidade e, dispersando-a, provoca uma multiplicidade de função e sentido, o que é dado pelo próprio enunciado. Segue, posto dessa maneira, que

a análise enunciativa é, pois, uma análise histórica, mas que se mantém fora de qualquer interpretação: às coisas ditas, não pergunta o que escondem, o que nelas estava dito e o não-dito que involuntariamente recobrem, a abundância de pensamentos, imagens ou fantasmas que as habitam; mas, ao contrário, de que modo existem, o que significa para elas o fato de se terem manifestado, de terem deixado rastros e, talvez, de permanecerem para uma reutilização eventual; o que é para elas o fato de terem aparecido - e nenhuma outra em seu lugar. Desse ponto de vista, não se reconhece nenhum enunciado latente: pois aquilo a que nos dirigimos está na evidência da linguagem efetiva ${ }^{44}$.

\footnotetext{
${ }^{42}$ Ibidem, p. 114.

${ }^{43}$ FOUCAULT, M. Raymond Roussel, p.145.

${ }^{44}$ FOUCAULT, M. A arqueologia do saber, p. 126.
} 
A partir destes termos, podemos sustentar que a arqueologia operará no sentido de colocar em xeque não somente a história, mas tudo o que, na sua mais visível superfície e invadindo toda porosidade inesgotável de sua área, tenha existido até o presente momento como verdadeiro. Transfundir os limites da história e os nossos próprios é a tentativa recorrente própria da arqueologia, pois, ao conferir um novo estatuto ao enunciado, engendra novos vínculos com as funções objetivas e subjetivas, indissociadas de uma ligação com a linguagem que procura explorar e invadir tudo o que uma formação histórica pode dizer e nos permite ver. Seu efeito, deste modo, é o de rachar as coisas, as palavras, os acontecimentos para que, nesta ação, a formação do novo seja alçada.

Cremos que, assim, cumpre pensar a tarefa do que se dispõe à análise, por intermédio dessa amplitude e abertura irredutíveis da linguagem, à guisa da interpretação. Sob esse contorno que começa a ser pautado, podemos avistar uma angústia da qual não nos livraremos mais: por um lado, nas palavras de Foucault, "a interpretação encontra-se diante da obrigação de interpretar-se a si mesmo até o infinito; de voltar a encontrar-se consigo mesmo" "45; mas, por outro, a ela se impõe o quem interpreta?, portanto traz a interpretação para o âmbito do intérprete. Mais uma vez estão relacionadas a continuidade e a descontinuidade. Aquela presente no aspecto infinito da interpretação; esta presente no aspecto finito de quem faz interpretar. Estranho jogo que passa a dominar a história, o que podemos fazer e, no limite, o que somos nela.

Contudo, ao levarmos em consideração a problemática do lugar de onde se fala, tocamos na questão cujo alcance faz lançar a arqueologia para o que está imbricado com a descrição dos enunciados a partir da massa histórica que, ao ser revirada, revisitada, reanalisada, turvada pela ação crítica que faz os seus resíduos sedimentados imiscuírem-se à aparente diafaneidade do pensamento histórico, constitui o que é denominado de arquivo. Posto que o enunciado se estabelece no registro do dito e do não dito, melhor seria dizer: registra-se no âmbito discursivo e não discursivo. Podemos dizer, a partir daí, que o arquivo se faz operar por intermédio de uma massa de enunciado que se estabilizou, mas que nem por isso deixa de sofrer mutações. Sob esse aspecto, no limite, a arqueologia poderia ser designada como a descrição do arquivo que elabora. Pródigo e inesgotável, o arquivo tende para "a massa de coisas ditas numa cultura, conservadas, valorizadas, repetidas e transformadas. Em suma, toda essa massa verbal que foi fabricada pelos homens, investida nas suas técnicas e instituições, e que é tecida com sua existência e sua história"46. A partir de

\footnotetext{
${ }^{45}$ FOUCAULT, M. Nietzsche, Freud e Marx, p.26.

${ }^{46}$ FOUCAULT, M. La naissance d'un monde. Dits et Écrist I, No 68, 1969, p.786.
} 
tal definição, é possível conceber que, no mesmo sentido do enunciado, o arquivo faz vir à tona uma função menos adstrita à soma de textos que uma cultura produziu, salvaguardou consigo, do que o sintoma de uma época que pode ser identificada, nomeada e descrita, pelas operações que o arquivo concede ao pensamento. Na mesma proporção, essas operações não são o núcleo institucional em que se permitiu, numa determinada sociedade ou época, o registro ou a conservação de discursos componentes de um certo fôlego histórico.

O arquivo, stricto senso, é composto pelas séries de enunciados, cuja sistematização ocorre na medida em que permitem uma coesão ao redor de certas funções e práticas. Assim, devemos entender que essa formação não foge às constituições discursivas e não discursivas que atravessam as relações históricas de uma época, quais sejam, saberes, práticas, decisões, enfim, o núcleo a partir do qual as relações humanas - e somente certas relações - são possíveis numa configuração e podem ser pensadas. Concebido assim, numa primeira possibilidade, o arquivo dispõe tudo o que foi dito e não dito, desde sempre, não segundo as leis do pensamento, das circunstâncias ou daquilo que sinalizou para um desenrolar de ordem das coisas. Ao contrário, ele se dispõe graças a um tipo de relações que, numa espécie incansável de jogo dinâmico, caracterizam-se particularmente no nível enunciativo, ou seja, segundo regularidades específicas que vão permitir um conjunto limitado de práticas ${ }^{47}$.

De uma outra forma, se é pelo arquivo que a arqueologia se faz falar, nos termos de Foucault, "não é preciso perguntar sua razão imediata às coisas que aí se encontram ditas ou aos homens que as disseram, mas ao sistema da discursividade, às possibilidades e às impossibilidades enunciativas que ele conduz" ${ }^{48}$. Para nós, isto equivale a dizer que o arquivo, de pronto circunscreve a própria lei do que pode ser dito, "o sistema que rege o aparecimento dos enunciados como acontecimentos singulares"49. Com efeito, o arquivo opera - mutatis mutandis -, permitindo que as coisas ditas, a prática e o acontecimento não apareçam de uma maneira desconfigurada, numa massa amorfa de dados, muito menos numa

\footnotetext{
${ }^{47}$ De fato, aqui surge um problema na filosofia de Foucault. Ora, se o arquivo concebe os limites históricos, ou seja, não se pode ir além desses limites, estaríamos condenados a um determinismo devido à ação dessa força que opera como se fosse uma vontade inexorável? Na realidade, um dos objetivos da história crítica do pensamento é justamente tentar se apropriar das constituições que fizeram caracterizar o arquivo. A saída, Foucault assesta, está na medida em que, ao sabermos, ou melhor, ao tomarmos consciência de como fomos constituídos, podemos tentar exercer uma nova relação de força ou prática que, de maneira microfísica, operaria como uma contra-força dentro da extensão do arquivo. Mas aí, julgamos nós, Foucault já não conseguiria ir além da necessidade do esclarecimento para tamanha tarefa, e isto, sem dúvida, seria uma das questões de improvável solvência. De qualquer maneira, segundo a nossa hipótese, ele aponta determinados caminhos no sentido de constituir uma discussão que tente superar esse fator limitante. Para tanto, irá problematizar, a partir do que denominou experiência-limite e atitude-limite, um viés pragmático de contra-força para operar sobre estes limites, sem recair, deste modo, na demanda do esclarecimento.

${ }^{48}$ FOUCAULT, M. A arqueologia do saber, p.149.

${ }^{49}$ Ibidem, Id.
} 
linearidade qualquer, porém ele é o que reúne, no sentido do sistema de enunciabilidade, as diversas funções dos múltiplos modos de validade discursiva.

Todavia, se o arquivo organiza a configuração do que podemos dar à descrição histórica, na mesma dimensão, é preciso ressaltar que

longe de ser o que unifica tudo que foi dito no grande murmúrio confuso de um discurso, longe de ser apenas o que nos assegura a existência no meio do discurso mantido, é o que diferencia os discursos em sua existência múltipla e os especifica em sua duração própria ${ }^{50}$.

Compreendemos, nessas condições, que o arquivo é de ampla mutação, uma vez que só pode ser definido em um nível particular, pois está forçosamente submetido às regras do enunciado e da enunciação; o que faz, mais uma vez, situar os acontecimentos da ordem descritiva no registro da descontinuidade.

Um duplo problema, porém, delineia-se na ordem do arquivo. De um lado, como se dá a forma desse conhecimento; e de outro, se essa perspectiva não dotaria, de fato, os domínios dos saberes ou dos registros históricos numa pré-definição prática, num engessamento de análise, portanto numa determinação qualquer, fazendo fechar sobre si mesmo um campo que não permitiria nenhuma mudança histórica. Julgamos que essa última questão não é um ponto desprezível. Contudo cremos ser a partir da noção de a priori histórico, muito próxima ao campo da épistémè, das positividades e do próprio arquivo, que ensaiaremos os primeiros passos na direção do esclarecimento desse revés crucial.

Até o momento, vimos delinear o desenvolvimento de um pensamento que se debruça notadamente sobre a função do que é descrito, ou seja, a história torna-se uma experiência empírica porque faz registrar o que está na ordem do enunciado, por sua vez, remetendo-nos para um conjunto de práticas. A história, sob esse ponto de vista, é extremamente prática; quer dizer, a prática não comporta uma instância misteriosa e oculta como motor dos acontecimentos, fatos, decisões e práticas humanas, não há um subsolo. Ela é estritamente o que é a conduta possível diante dos enunciados: tudo é histórico e, sob esta ótica, depende de tudo; nada é inerte, indeterminado e inexplicável ${ }^{51}$. Falamos no interior das próprias regras do

\footnotetext{
${ }^{50}$ Ibidem, Id.

${ }^{51}$ As últimas expressões são de Veyne, que julgamos evidenciar essa questão de maneira cabível, embora não concordemos com a expressão total de sua compreensão acerca do pensamento de Foucault, como já indicamos: "Aí está, pois, um universo inteiramente material, feito de referentes pré-discursivos que são virtualidades ainda sem rosto; práticas sempre diversas engendram nele, em pontos diferentes, objetivações sempre diversas, rostos; cada prática depende de todas as outras e de suas transformações, tudo é histórico e tudo depende de tudo; nada é inerte, nada é indeterminado e nada é inexplicável; longe de depender de nossa consciência, esse mundo a determina. Primeira conseqüência: tal referente não tem tendência a tomar esse ou aquele rosto, sempre o mesmo a vir a ter tal objetivação, Estado, loucura ou religião; é a famosa teoria das descontinuidades: não existe
} 
arquivo, assim há uma condição para a nomeação da função que se faz surgir. Fala-se, portanto, para se cumprir uma função, mas de acordo com uma certa condição. E são voltados para essa condição que tanto o a priori histórico quanto a sua face epistemológica vão operar.

Face a face com o arquivo, o a priori histórico se situa na positividade de um discurso, isto é, no domínio que ganhou uma unidade através do tempo, que é o espaço limitado de comunicação por intermédio do qual as coisas falam. Coisas aqui equivalem a tudo o que já foi, pode ser e ainda será nomeado, também ao dito e não dito. Por essa razão, o a priori histórico relaciona-se à condição que permitirá a realidade de um enunciado, mas é preciso notar bem: na dispersão dos enunciados. Assim, "diante dos a priori formais cuja jurisdição se estende sem contingência", e para se opor a eles, o a priori histórico

é uma figura puramente empírica; mas, por outro lado, já que permite compreender os discursos na lei de seu devir efetivo, deve poder dar conta do fato de que tal discurso, em um momento dado, possa acolher e utilizar ou, ao contrário, excluir, esquecer ou desconhecer esta ou aquela estrutura formal ${ }^{52}$.

Podemos, então, dizer: o a priori histórico é o recorte no qual um conjunto de regras se caracteriza numa prática discursiva, e vice-versa. Todavia não encontramos uma sobredeterminação que implicaria numa sistematização unitária, fechada e de coerência homogênea. Estaríamos mais próximos de um tipo de organização para um saber ou práticas possíveis; logo esta concepção põe à mostra os efeitos de relações de força que se efetivam sob determinadas condições que delimitam o fora (dehors) - positividade, épistémè, mas que também ultrapassa o dentro (dedans) - discurso, enunciado, arquivo.

Sendo assim, ao ordenar, de um lado, o sistema de enunciabilidade do arquivo e, de outro, o seu funcionamento, o a priori histórico faz emergir a condição real em que o acontecimento, o pensamento, a regra, o que é dito e não dito podem ocorrer. Mas atenção. Isto não significa que esta regularidade específica determine a condição histórica. Foucault bem nos alerta:

nada, pois, seria mais agradável, mas menos exato, que conceber esse a priori histórico como um a priori formal e, além do mais, dotado de uma história: grande figura imóvel e vazia que surgiria, um dia, à superfície do tempo; que faria valer sobre o pensamento dos homens uma tirania da qual ninguém poderia escapar; que depois desapareceria, de repente, em um eclipse a que nenhum acontecimento teria dado sinal prévio $^{53}$.

'loucura através dos tempos', religião ou medicina através dos tempos." (VEYNE, P. Como se escreve a história e Foucault revoluciona a história. Brasília: Editora UNB, 1998, p.268.)

${ }_{53}^{52}$ FOUCAULT, M. A arqueologia do saber, p.147.

${ }^{53}$ Ibidem, p. 148 . 
$\mathrm{Na}$ verdade, podemos pensar, aqui cabe bem a ironia foucaultiana ao utilizar um conceito tão referenciado na história da filosofia ocidental para negar o que se imagina como dado ou anteposto ao próprio pensamento. A razão histórica não é um grande sussurro cuja voz silente não possa ser amplificada por aquilo que ela pratica. As idéias que se formulam num determinado momento, assim como os comportamentos que podem se manifestar também num momento qualquer, dão-se pelo que se pode falar e ver ${ }^{54}$.

Disposto desta maneira, por mais heteróclito que seja, o a priori histórico aceita as transformações que são hauridas por novos campos de equivalência enunciativa, ou seja, o seu espaço, como quer provar a descrição arqueológica, pode ser distinto, como também o seu alcance. Dá-se nessa dimensão a sua efetividade epistemológica que também é histórica. Significa pensar que a história está no limiar constante de um umbral de transformações e modificações que permitem novas formações discursivas. Assim, a épistémè nada mais é do que um espaço de dispersão. Não se trata, então, de pensarmos na soma dos conhecimentos de uma época ou do estilo geral que se impõe ao pensamento, mas, em campo de afastamento, de novas distâncias, oposições e diferenças, em relações múltiplas que podem ocorrer sob a esfera de um enunciado discursivo ou não discursivo. Como atesta Foucault, "a épistémè não é um tipo de grande teoria subjacente, é um espaço de dispersão, é um campo aberto e sem dúvida indefinidamente descritível de relações"

Ora, a história crítica do pensamento em sua perspectiva arqueológica se debruça exatamente sobre as relações complexas de deslocamentos, ou melhor, de rupturas e descontinuidades que o campo epistemológico e das práticas oferecem empiricamente ao próprio pensamento ${ }^{56}$. Decorre disso o fato de ser a arqueologia o fator primordial para se fazer do pensamento um diagnóstico das possibilidades de transformação histórica. Assim, nos termos generosos de Foucault, o diagnóstico se dá

\footnotetext{
${ }^{54}$ A contribuição de Deleuze, nesse sentido, é inestimável: “[...] as condições do a-priori são condições da experiência real, e não de toda experiência possível (os enunciados, por exemplo, supõem um corpus determinado); elas estão do lado do "objeto", do lado da formação histórica, e não de um sujeito universal (o $a$ priori é ele mesmo histórico).”(DELEUZE, G. Foucault. Paris: Éditions de Minuit, 1986, p. 67.)

${ }_{55}^{55}$ FOUCAULT, M. Reponse à une question. Dits et Écrits I, No 58, 1968, p.676.

${ }^{56}$ De nossa parte, sustentamos que este campo não se reduz ao saber. O desenvolvimento do pensamento de Foucault problematizou de formas distintas esse húmus de onde a história se colocou para efetivar o que foi já efetivado. Isto ocorreu em diferentes esferas: no saber, no poder, na sexualidade, na ética, enfim. Argumentamos, à guisa do comentário de Machado, que o que se tornou conhecido como "arqueologia do saber" não é um ponto de partida dentro do que estamos denominando história crítica do pensamento. Mas é o resultado de um processo, ele mesmo histórico, pelo qual o conceito de arqueologia conheceu modificações que aparecem de modo diferente em cada obra. (Cf. MACHADO, R. Archéologie et épistémologie. In. Michel Foucault Philosophe: Rencontre Internationale. Paris, 9, 10, 11 janvier 1988. Paris, Seuil 1989, p.15-32.).
} 
não porque nos permitiria levantar o quadro de nossos traços distintivos e esboçar, antecipadamente, o perfil que teremos no futuro, mas porque nos desprende de nossas continuidades: dissipa essa identidade temporal em que gostamos de nos olhar para conjurar as rupturas da história; rompe o fio das teleologias transcendentais e aí onde o pensamento antropológico interrogava o ser do homem ou sua subjetividade, faz com que o outro e o externo se manifestem com evidência. $O$ diagnóstico assim entendido não estabelece a autenticação de nossa identidade pelo jogo das distinções. Ele estabelece que somos diferença, que nossa razão é a diferença dos discursos, nossa história a diferença dos tempos, nosso eu a diferença das máscaras. Que a diferença, longe de ser origem esquecida e recoberta, é a dispersão que somos e que fazemos ${ }^{57}$.

À luz desses termos, faz sentido, agora, pensarmos que a história crítica do pensamento, sob a perspectiva da arqueologia, interroga o já-dito no nível de sua existência; e, ao fazê-lo, já principia, desde cedo, a abertura crítica que se põe em face do que somos, pensamos e fazemos. Mas aí é o aprofundamento na forma de se indagar pelo valor da origem dessas coisas que está em jogo, donde vemos surgir a tarefa crítica do pensamento em sua genealogia.

\subsection{Genealogia}

A genealogia retoma a problemática e levanta novas questões acerca da relação do objeto, sujeito e temporalidade na história, mas cercando essas questões com o foco do valor encontrado na verdade e na interpretação históricas, no intuito de forjar uma história efetiva. Em nossa interpretação, Foucault quer aprofundar e dilatar o alcance do projeto inicial, respaldado no procedimento arqueológico: "fazer uma história inteiramente diferente daquilo que os homens disseram" 58 . Para tanto, há um múltiplo acumulado de questões que não atuam de maneira linear, como se fosse possível encontrar apenas um fio condutor que amarraria todo o empreendimento foucaultiano; muito menos de forma contínua, pressupondo graus idênticos rumo a uma evolução progressiva de uma tarefa qualquer; ou, sob outro prisma, engendrando uma total ruptura interna cujos caminhos de ligação ficariam prejudicados por uma total novidade de atuação, negando o que até o momento foi pensado.

A genealogia, ao que nos parece, não surge como um novo sol abrupto a iluminar a história crítica do pensamento, pois é devedora de toda herança arqueológica que instaurou a

\footnotetext{
${ }^{57}$ FOUCAULT, M. A arqueologia do saber, p.151.

${ }^{58}$ FOUCAULT, M. A arqueologia do saber, p.159.
} 
descontinuidade na história, dando condições de visibilidade a uma série de práticas heterogêneas que, desde então, podem ser avalizadas de uma outra perspectiva. Quer dizer, se a problemática da história é o eixo central por onde o campo do pensamento de Foucault circula, havemos de pensar que este eixo permite uma rotação e um movimento pendular constantes, dispondo-se em transversalidades diferentes. Bem podemos designar essa dinâmica de transmutação arqueológica, isto é, a maneira distinta, múltipla, renovada e exigente de uma demanda crítica que continuará a colocar a história do que até o instante os homens disseram sob constante suspeição. Sendo assim, a genealogia incide como marca dinâmica desse movimento não para negar ou superar a demanda arqueológica, mas para intensificar os modos de extrairmos visibilidades das formações históricas e, por conseguinte, de nossa própria constituição. De fato, se as perguntas da genealogia podem ser novas, como assim podem ser seus olhos, isso se deve ao trabalho de desmoronamento que a arqueologia fez à história contínua, compacta, progressiva, de força invisível, globalizante e unificadora. Ora, não seria simples, daí, pensarmos que uma nova região pôde ser descoberta? É claro, mas, para tanto, o que impedia o surgimento do novo horizonte ou a descoberta de uma nova região precisou ser metodicamente posto ao chão. Certo; mas como se dá, então, a operação desse movimento? Afinal, se são perspectivas distintas, pois o movimento é perpendicular, o que cada movimento pode trazer à tona? Ou ainda, como seria a composição do movimento posto no lado genealógico, quer dizer, o que isto abrangeria? Como abrangeria? Cremos que responder a tais indagações nos ajudará a pôr em evidência a importância da genealogia na direção de um procedimento-método que leva às últimas conseqüências o tipo de pensamento que toma a história como o que nos separa de nós mesmos, "e o que devemos transpor e atravessar para nos pensarmos a nós mesmos"

A nós importa, de antemão, partir da clareza proposta pelo próprio Foucault ao situar o que ele designou de seu "projeto geral" sob os seguintes termos: "enquanto a arqueologia é o método próprio à análise da discursividade local, a genealogia é a tática que, a partir da discursividade local assim descrita, ativa os saberes libertos da sujeição que emergem desta discursividade" ${ }^{\prime 60}$. Devemos notar que o movimento que ocorre do método para a tática não prescinde de um modo de experiência historicamente singular, ambos, é preciso ressaltar, são atinentes à discursividade. Pouco importa, no caso, se se diz respeito às suas vertentes

\footnotetext{
${ }^{59}$ Cf. DELEUZE, G. Conversações. São Paulo: Editora 34, 1992, p.119. Neste sentido, Deleuze ainda afirmará que "a arqueologia, a genealogia, são igualmente uma geologia" (Ibidem, p.120). Ao que nos parece, vemos nisto a perspectiva de remontarmos à idéia de níveis que se entrecruzam, interpõem-se e só podem ser analisados por recortes: amostragens. Pensamos ser isto um modo interessante de também conceber o que chamamos de múltiplo acumulado.

${ }^{60}$ FOUCAULT, M. Genealogia e poder. In. Microfísica do Poder, p.172.
} 
discursiva e/ou não-discursiva. A arqueologia descreve o arquivo que condensou as relações do discurso, quer dizer, a sua pontualidade, que está manifestada em uma regra, norma, numa verdade, mas que também pode estar numa instituição, em um hospital, asilo ou prisão. Mas se a arqueologia é método, é a partir dele que se coloca em ação a tática de ativar o que a descrição dá visibilidade, com o intuito de se saber como ocorreu a emergência de determinada discursividade que agora pode ser materializada pela própria descrição. Então, arqueologia e genealogia operam em conjunto como investigação histórico-crítica do pensamento, abrangendo, para utilizarmos uma expressão já situada na História da Loucura, “o interior e o exterior" por onde a história procura interrogar o fato e as condições da aparição manifesta de toda discursividade. A rigor, contudo, isto não significaria negar a genealogia enquanto método. Todavia nos colocamos mais na direção em que ela representa um tipo de procedimento que, de tanto alargar o horizonte valorativo que há na história, implode a possibilidade de qualquer tipo de neutralidade que um método pressupõe. Não é à toa que Foucault, inaugurando uma acepção própria, portanto, apela para o peso do termo tática $^{61}$. É preciso, então, ver a genealogia como um método entre aspas.

Sob esse horizonte, a tática local, por assim dizer, funciona como lente de aumento para o trabalho histórico que inaugurou a sua descontinuidade e do que se pode pensar à sua guisa. Contra as raízes calcinadas do sentido, o foco desta lente consegue enxergar desde a menor capilaridade histórica, o que ocultava ao pensamento a sua efetiva história, não pelo fato de ser ideologia, inversão para o pensamento da verdade a ser purificada, muito menos por criar mentiras pelas quais os homens pudessem tomar como verdade, porém a genealogia como tática local faz ver que a história é verdade, que o que ela diz e faz são as suas práticas mesmas, não, contudo, sem indicar que "toda verdade tem como função recobrir" ${ }^{2}$. Podemos, assim, entender que ainda estamos ao alcance da especificidade da obra de Foucault para qual todo maciço histórico deve ser dissolvido, sob o efeito da dissipação ou da raridade que compõe o grão deste maciço, com o intuito de pontuar ainda mais a tarefa crítica. Assim, a genealogia tratará de colocar em xeque o valor de todas as relações e práticas históricas cujos

\footnotetext{
${ }^{61}$ Seria nesta direção que interpretaríamos a afirmação de Deleuze ao sustentar que, em Foucault, "a história faz parte de seu método" (Cf. Conversações. São Paulo: Editora 34, 1992, p.118). É óbvio que está também em jogo um tipo de especificidade de trabalho devedor das abordagens arqueológicas. Ainda a este propósito, devemos colocar neste mesmo horizonte a recepção dos termos de Revel, para quem "o método genealógico é na realidade uma tentativa de dessujeitar os saberes históricos, isto é, torná-los capazes de oposição e luta contra a 'ordem do discurso' que é também uma ordem do saber" (Cf. REVEL, J. Expériences de la pensée: Michel Foucault. Paris: Bordas, 2005, p.76)

${ }^{62}$ FOUCAULT, M. Nietzsche, Freud, Marx, p.24.
} 
contornos se forjaram pela película da verdade histórica, que deve ser vista sob outro foco: pela lente de aproximação da genealogia ${ }^{63}$.

Sendo assim, Foucault assinala de maneira clara a região de prospecção em que a tática genealógica se colocará:

a história crítica do pensamento não é nem uma história das aquisições nem uma história das ocultações da verdade; é a história da emergência dos jogos de verdade: é a história das veridicções (véridictions), entendidas como as formas segundo as quais se articulam sobre um domínio de coisas, dos discursos suscetíveis de serem ditos verdadeiros ou falsos: quais foram as condições desta emergência, o preço com o qual, de todo modo, ela [a emergência] pagou, seus efeitos sobre o real e a maneira pela qual, ligando um certo tipo de objeto a certas modalidades do sujeito, ela constituiu, para um tempo, uma superfície e indivíduos dados, o a priori histórico de uma experiência possível. ${ }^{64}$

É significativo, aqui, o fato de toda experiência possível ter a sua visibilidade por intermédio de um campo emergencial. Ao se colocar como perspectiva de ação da história crítica do pensamento, a genealogia continua a desferir golpes sobre o reino das verdades que entronizavam um conjunto de práticas históricas - exterioridades - a partir de uma plenitude espaço-temporal, cuja gênese linear era inerente ao próprio campo da verdade. Mas, se as condições de emergência de toda exterioridade se condicionam à própria possibilidade de seu surgimento, o que lhe é latente, podemos afirmar que a genealogia aceita a descontinuidade, quer dizer, põe-se a perseguir o fio das transformações históricas.

Então, quando Foucault diz que "a genealogia é cinza; ela é meticulosamente e pacientemente documentada" 65 , está assinalando para as transformações históricas que não podem ser compreendidas distantes de tudo o que o arquivo histórico abarca. O cinza da

\footnotetext{
${ }^{63}$ Dessa perspectiva colocamos em suspeição a interpretação proposta por Dreyfus e Rabinow ao sustentarem que "Foucault introduz a genealogia a partir de seu próprio interior"; e que a arqueologia se circunscreveria a um "estudo das teorias das ciências humanas como discurso-objeto" e, ainda, que, como tal, subordina-se à genealogia pelo fato desta nos remeter a uma dimensão prática enquanto a arqueologia a uma dimensão teórica (Cf. DREYFUS, H. e RABINOW, P. Michel Foucault: uma trajetória filosófica - para além do estruturalismo e da hermenêtica. Rio de Janeiro: Forense, 1995, p.115 e 114) Essa perspectiva se sustenta na medida em que concebe arqueologia e genealogia como métodos diferentes e cumprindo papéis não cambiáveis. Mas, se sustentamos que a genealogia é uma tática operacional, funcionando como uma lente de aumento, na verdade, coloca-se em evidência um aspecto fundamental da arqueologia. Para nos valermos das palavras de Veyne: "Toda história é arqueológica por natureza e não por escolha: explicar e explicar a história consiste, primeiramente, em vê-la em seu conjunto, em correlacionar os pretensos objetos naturais às práticas datadas e raras que os objetivizam, e em explicar essas práticas não a partir de uma causa única, mas a partir de todas as práticas vizinhas nas quais se ancoram. Esse método pictórico produz quadros estranhos, onde as relações substituem os objetos." (Cf. VEYNE, P. Como se escreve a história e Foucault revoluciona a história. Brasília: Editora UNB 4.ed. 1998. p.280). Ora, mostrar que as relações substituíram os objetos é o papel da "lente de aumento" da genealogia. Isto é uma tática, na própria expressão de Foucault, e não mais um método stricto senso.

${ }^{64}$ FOUCAULT, M. Foucault. Dits et Écrits IV, No 345,1984 , p.632.

${ }^{65}$ FOUCAULT, M. Nietzsche, genealogia e história. In. Microfísica do Poder, p.15.
} 
genealogia também nos lembra a cor cinzenta do arquivo que o método arqueológico tentou descrever, evidenciando as maneiras pelas quais os enunciados históricos apareciam, eram conservados e estabelecidos, assumindo este ou aquele papel num jogo intermitente de valores, investindo sobre práticas ou condutas, princípios que deveriam circular ou ser afastados, esquecidos, destruídos ou reativados. Posto dessa forma, pensamos que o arquivo não se encerra na arqueologia; ele é amplificado pela lente genealógica dotada de um questionamento próprio que sabe que as palavras não guardam seu sentido, os desejos a sua direção, nem as idéias uma lógica perfeita. Daí o gosto de Foucault pelos fatos negligenciados, pelos objetos históricos que não resguardam nenhum tipo de evidência meritocrática: loucos, monstros, anormais, prisioneiros, homens e mulheres vexados; de perto, os acontecimentos, fatos e coisas invisíveis, o que foi deixado à beira do caminho ganham um outro valor, mas também fazem revelar o que não se via.

Concernente a tal perspectiva e de modo mais preciso, a genealogia põe em ação um procedimento, já que é uma tática também a operar sobre o arquivo, permitindo à ação do pensamento uma postura que irradiará na história, produzindo o que se poderia chamar, para utilizarmos uma expressão do filósofo, "insurreição dos saberes dominados",66. Esta insurreição é ação histórica disjuntiva que ganha força para se antepor não somente à gênese linear dos fatos históricos, mas também a toda finalidade monótona cuja curvatura histórica ansiava fechar sobre si mesma debaixo de uma contínua evolução. Em busca da singularidade dos acontecimentos, a genealogia opera para reencontrar as diferentes cenas nas quais o que se deu como saber histórico se encontra limitado, melhor dizer, dominado.

O saber histórico dominado é o princípio ativo do valor de verdade que a história fez emergir. Aliás, é o fato histórico tomado por verídico, quer dizer, como experiência fundamental que se desenvolveu no tempo e no espaço de um saber complexo em que passam a ser dominados, uma vez que "os conteúdos históricos que foram sepultados, mascarados em coerências funcionais ou em sistematizações formais" ${ }^{67}$ passaram a ligar a história a uma determinada situação de origem. Mas, ao buscar nos conteúdos históricos o que pode permitir enxergar uma clivagem dos confrontos históricos, das lutas, das diferenças; o que, como não é mais possível ignorar, experimentou e "conheceu o mundo das invasões, lutas, rapinas, disfarces, astúcias" ${ }^{68}$; o que foi tomado por indigno e tido como não possuidor de uma história, doravante, a genealogia passa a abordar como realidade histórica suscetível de

\footnotetext{
${ }^{66}$ FOUCAULT, M. Genealogia e Poder. In. Microfísica do Poder, p.170.

${ }^{67}$ Ibidem, Id.

${ }^{68}$ FOUCAULT, M. Nietzsche, genealogia e história. In. Microfísica do Poder, p.15.
} 
transformação e capaz de provocar transformação. Portanto, tudo se torna conteúdo histórico. E, desta maneira, ela arma a sua tática para que o pensamento faça a sua prospecção nos saberes dominados, entendidos, neste nível, como os "blocos de saber histórico que estavam presentes e mascarados no interior dos conjuntos funcionais e sistemáticos e que a crítica pode fazer reaparecer" ${ }^{\circ 9}$. O que Foucault designa de conjuntos funcionais ou sistemáticos são justamente o que, a partir dos enunciados discursivos e não discursivos, situou-se como verdadeiro. A verdade colocada no discurso e na prática do sistema penal, por exemplo, não vai ao encontro da correção; todavia, se olharmos pela lente genealógica vemos ali a instituição das práticas de punição, de cerceamento de liberdade, de contenção de um exército de reserva, enfim, de tudo, menos de intenção correcional. A genealogia revira as verdades, cujas organizações funcionais ou sistemáticas tiveram e têm por objetivo mascarar ${ }^{70}$.

Mas há ainda um outro nível na forma desse saber dominado. Se, de um lado, o saber dominado se apresenta pelo viés de conteúdos históricos que tratam a verdade como o efeito de uma máscara, de um outro, e em certo sentido diferente, o saber dominado também será tomado como "uma série de saberes que tinham sido desqualificados como não competentes ou insuficientemente elaborados: saberes ingênuos, hierarquicamente inferiores, saberes abaixo do nível requerido de conhecimento ou de cientificidade" ${ }^{71}$. A partir disto, podemos conceber que a herança do trabalho pontual exercido pela arqueologia não estará ausente na perspectiva genealógica, de sorte que a força mais evidente da história crítica do pensamento irá se dar pelo rigor que a lente da genealogia, lentamente ou com a persistência demorada a ela inerente, incidirá sobre o foco histórico. Tanto é assim que, como atesta Foucault,

foi o reaparecimento destes saberes que estão embaixo - saberes não qualificados, e mesmos desqualificados, do psiquiatrizado, do doente, do enfermeiro, do médico paralelo e marginal em relação ao saber médico, do delinqüente etc., que chamarei de saber das pessoas e que não é de forma alguma um saber comum, um bom senso mas, ao contrário, um saber particular, regional, local, um saber diferencial incapaz de

\footnotetext{
${ }^{69}$ FOUCAULT, M. Genealogia e Poder. In. Microfísica do Poder, p.170.

70 É de boa monta explicitar o seguinte aspecto: mais adiante, mostraremos que a "máscara", de fato, será metáfora marcante acerca de determinada função tangente à genealogia. Contudo, especificamente no contexto em que nos encontramos, acenamos para o comentário de Deleuze ao nos lembrar que toda "interdição, exclusão, limites, liberdades, transgressões estão ligadas a uma prática discursiva determinada, relacionada com os meios não discursivos" (DELEUZE, G. Foucault. Paris: Éditions de Minuit, 1986, p.251), o que nos leva a pensar no trabalho de investigação relacionado aos acontecimentos, instituições e outras práticas que Foucault obstinadamente persegue para revelar as discursividades. Com isso, mantemos em cena a importância de não restringir o conjunto de temáticas referente ao discurso no campo arqueológico. Destarte, a genealogia também acena para a importância desse saber. Tanto é que ela irá justamente acentuar que o maior distanciamento histórico nada mais é do que, conforme ainda assevera Deleuze, "superfícies superpostas, arquivos e estratos" (Ibidem. p.128).

${ }^{71}$ FOUCAULT, M. Genealogia e Poder. In. Microfísica do Poder, p.170.
} 
unanimidade e que só deve sua força à dimensão que o opõe a todos aqueles que o circundam - que realizou a crítica ${ }^{72}$.

É possível aduzir desta relação um fator importante. De um lado, encontramos um saber dominado posto no registro das organizações ou das sistematizações dos discursos, práticos ou não, operando como salvaguardas de uma verdade instituída. De outro, encontramos um saber dominado que, diferentemente daquele, é desqualificado ou rejeitado pelo domínio do que está instituído. Ao primeiro, Foucault nos permite designá-lo de saber do instrumento da erudição, cuja categoria se insere nos "conteúdos do conhecimento histórico, meticuloso, erudito, exato"73; ao segundo, o filósofo nos permite designá-lo de saber desqualificado, cuja categoria se insere nos "saberes locais, singulares, estes saberes das pessoas que não são saberes sem senso comum e que foram deixados de lado, quando não foram efetivamente e explicitamente subordinados" ${ }^{74}$. É certo que o primeiro escreve a história dos vencedores, o que se narra como verdade oficial; já o segundo é o locus de onde é possível encontrar a memória de todos os combates e de todas as vozes sufocadas - grupos multivocais -, que põem em marcha uma realidade histórica que é de luta e de conflito, melhor dizendo, de relações de forças. Levando em consideração essa dinâmica inerente ao saber dominado, a genealogia se propõe a uma série de pesquisas múltiplas cujos fatores históricos, de ambos os lados, não podem ser mais ignorados.

Com efeito, sob este horizonte, podemos encontrar o balanço dinâmico e inquietante que ocorre na história crítica do pensamento. Notemos que a arqueologia travou a sua luta contra a perspectiva contínua da história, contra o que banalizava e tornava anacrônicos os níveis de práticas sucessivamente históricas. Pois bem, a "genealogia, como acoplamento do saber erudito e do saber das pessoas, só foi possível e só se pôde tentar realizá-la à condição de que fosse eliminada a tirania dos discursos englobantes com suas hierarquias e com os privilégios da vanguarda teórica" ${ }^{\text {75 }}$.

Sendo assim, fica mais evidente que a genealogia se dispõe aos efeitos do trabalho arqueológico inaugurado por Foucault, sempre tendo em mente aquele ponto obsedante "no campo em que se manifestam, se cruzam, se emaranham e se especificam as questões do ser humano, da consciência, da origem e do sujeito" ${ }^{, 76}$. Donde, então, algo se deixa avistar como

\footnotetext{
${ }^{72}$ Ibidem, Id.

${ }^{73}$ Ibidem, Id.

${ }^{74}$ Ibidem, Id.

${ }^{75}$ Ibidem, p. 171.

${ }^{76}$ FOUCAULT, M. A arqueologia do saber, p.19.
} 
empreendimento para liberar da sujeição os saberes históricos, para utilizarmos uma expressão de Foucault:

não é um empirismo nem um positivismo, no sentido habitual do termo, que permeiam o projeto genealógico. Trata-se de ativar saberes locais, descontínuos, desqualificados, não legitimados, contra a instância teórica unitária que pretendia depurá-los, hierarquizá-los, ordená-los em nome de um conhecimento verdadeiro, em nome dos direitos de uma ciência detida por alguns. As genealogias não são, portanto, retornos positivistas a uma forma de ciência mais atenta ou mais exata, mas anti-ciências ${ }^{77}$.

Julgamos encontrar neste contexto a real dificuldade que este empreendimento traz ao próprio pensamento, pois não podemos desprezar que, em sua perspectiva genealógica, a história não conta mais com os discursos meramente teóricos, unitários, formais, globalizantes e, por que não dizer, científicos.

Situada desta maneira, a tática genealógica não se contentará com nenhum tipo de forma histórica que esteja atrelada ao discurso condizente de um só saber. É preciso fazer vir à tona as suas diferentes formas: saberes. Porque a arqueologia dissolveu a história em um campo múltiplo de problematização, donde se configura a própria essência da história crítica, com a genealogia não poderia ser diferente. Quando Foucault argumenta que gostaria de "fazer a genealogia de problemas, de problemáticas (problématiques)"78, está caminhando na direção de um conjunto de temas que não se colocam antes da investigação histórica. Ou seja, a arqueologia põe-se em movimento no sentido de superar o objeto e o sujeito dados, antes mesmo que a história pudesse dizer que se tratava de coisas diferentes ou de resultados distintos de todos aqueles que já se encontravam decalcados ao que um tipo determinado de sujeito pudesse fazer ou um tipo determinado de objeto pudesse revelar. Mas, sob a dinâmica da problematização, é preciso respeitar os desvios, os corredores obscuros, o que não foi povoado, a dimensão mais longínqua, que não deixa de estar tão próxima de nós quando se torna visível. Mesmo que haja uma intenção real e honesta a partir do que o historiador queira mostrar ao pensamento como fato, dado ou prática histórica, ele tem de saber que há sempre o risco de encontrar o que não imaginava ser possível, de ver o que ele julgava inexistente e de ouvir o que ele suspeitava como registro inaudito. A genealogia assume a forma de história crítica do pensamento na medida em que se coloca diante desta fresta aberta, metáfora em constante dilatação para a história, sem a pretensão de querer fechá-la.

\footnotetext{
${ }^{77}$ FOUCAULT, M. Genealogia e Poder. In. Microfísica do Poder, p.171.

${ }^{78}$ FOUCAULT, M. À propos de la généalogie de l'étique: un aperçu du travail en cours. Dits et Écrits IV, No 326,1983, p.386.
} 
Longe de qualquer equívoco nos encontraremos se afirmamos que a trajetória de Foucault vai se constituindo à guisa de um fazer histórico que não abre mão de ser mais potente e detalhista na forma pela qual se debruça sobre a constituição de seus temas-objeto. A força ativa da história terá na genealogia o seu catalisador mais poderoso, pois se põe em atividade a fim de ver como os problemas que podem ganhar visibilidade são constituídos, ou melhor, "ver como estes problemas de constituição" podem "ser resolvidos no interior de uma trama histórica" ${ }^{, 79}$. Para tanto, fez-se necessário focalizar a tática da genealogia numa direção que não somente tratou de se "livrar do sujeito constituinte", mas de "chegar a uma análise que possa dar conta da constituição do sujeito na trama histórica", o que não é tudo. Por mais estranho que possa parecer, a especificidade genealógica é ampla, quer dizer, não reconhece os limites de nenhuma passividade histórica. Assim, nas palavras de Foucault,

é isto que eu chamaria de genealogia, isto é, uma forma de história que dê conta da constituição dos saberes, dos discursos, dos domínios de objeto etc., sem ter que se referir a um sujeito, seja ele transcendente com relação ao campo de acontecimentos, seja perseguindo sua identidade vazia ao longo da história ${ }^{80}$.

Colocada neste nível, salta aos olhos que, de fato, a genealogia não trata de superar as questões que vêm sendo delineadas pelo pensamento de Foucault desde a arqueologia. Ao contrário, encontra-se desenhada, mesmo que de modo incipiente, no conjunto do método arqueológico, trabalha a seu favor e não contra ele, uma vez que, não importando onde se situa a dimensão do objeto, a genealogia o faz vir à luz a partir de sua constituição, certamente, não de modo unívoco, mas com a ascendência múltipla, que só foi possível em virtude do trabalho do arqueólogo. Fato que, para nós, mais uma vez, coloca à prova o sentido da prática relacionada à especificidade do pensamento de Foucault. Não sem sentido, iremos nos deparar com a seguinte afirmação advinda da introdução geral da História da sexualidade, de $1983^{81}$, portanto distantes de todo o foco da história concentrada nas práticas, como exigia, ab ovo, A arqueologia:

\footnotetext{
${ }^{79}$ FOUCAULT, M. Verdade e poder. In. Microfísica do Poder, p.07.

${ }^{80}$ Ibidem, Id.

81 Esta introdução consistia numa abordagem geral que conduziria as questões a serem desenvolvidas nas seguintes obras: $O$ uso dos prazeres, $O$ cuidado de si e Confissões da carne. Destas, somente as duas primeiras foram publicadas, correspondendo aos volumes II e III da História da Sexualidade. A introdução contida no volume II da História da Sexualidade (1984) sofreu sensível modificação. O fato de utilizarmos aqui a introdução de 1983 é que ela já indica a prática como elemento fundamental da genealogia, o que, para a tese que estamos sustentando, é importante, pois demonstra que a genealogia não causa uma ruptura traumática na obra de Foucault, mas a conduz para um amadurecimento lento e profundo acerca do trato com a história e a problemática da subjetividade.
} 
por genealogia eu não quero dizer uma história das concepções sucessivas do desejo, da concupiscência ou da libido, mas analisar as práticas pelas quais os indivíduos foram levados a prestar atenção a eles próprios, a se decifrar, a se reconhecer e se confessar como sujeito de desejo, estabelecendo entre eles mesmos e para eles mesmos uma certa relação que lhes permite descobrir, no desejo, a verdade de seu ser, seja ele natural ou decaído ${ }^{82}$.

Nessa configuração, fica patente o quanto a genealogia também operará dentro do campo das práticas históricas. Então elas não ficam restritas à função do método arqueológico, o que permite um acúmulo de ferramentas a serem utilizadas na tarefa de situar o próprio pensamento dentro da história. Assim, as práticas autorizam a genealogia partir de um "como" para atingir um "para", mas cuja pretensão não se fecha num contexto teleológico, ao contrário, abre-se numa sucessão de problematizações, donde prática e problematização não se separam ${ }^{83}$.

Uma diferença, no entanto, é fundamental e necessita ser indicada. Mesmo assim, esta não coloca em risco o que poderíamos chamar de fator aglutinador deste múltiplo acumulado que é a história crítica do pensamento, talvez pelo fato de termos, com as palavras de Foucault, a convicção de que "os estudos que seguem, assim como outros que anteriormente empreendi, são estudos de história pelos campos que tratam e pelas referências que assumem" ${ }^{\prime 4}$. É certo, arqueologia e genealogia são estudos de história, mas não perdem de vista a tarefa eminentemente filosófica que Foucault passa a lhes oferecer. De uma maneira simples, poderíamos mais uma vez com ele dizer um exercício filosófico, em que "sua articulação foi a de saber em que medida o trabalho de pensar sua própria história pode liberar

\footnotetext{
${ }^{82}$ FOUCAULT, M. Usage des plaisirs et techniques de soi. Dits et Écrits IV, $\mathrm{N}^{\circ} 338,1983$, p.541.

${ }^{83}$ Ao nos movermos na direção da prática, sob o comentário de Veyne, trazemos à tona o impacto revelador de que "[...] não existe verdade transistórica (sic.) concreta, natureza humana material, retorno de um recalque, pois a idéia de uma inclinação natural recalcada só tem sentido no caso de um indivíduo que teve sua própria história; no caso das sociedades, o recalque de uma época é, na realidade, a prática diferente de uma outra época, e o eventual retorno desse pretenso recalque é, na realidade, a gênese de uma nova prática" (Idem. p.272). Munidos disso, contestamos o argumento de Ferry e Renaut, que vêem no projeto da obra de Foucault "uma das mais singulares características da filosofia francesa", a saber, um "refrão da cançoneta anti-repressiva" (FERRY, L. e RENAUT, A. Pensamento 68: ensaio sobre o anti-humanismo contemporâneo. São Paulo: Ensaio, 1988. p.107 e 108). A noção de prática não viabiliza tal interpretação, além do fato de que toda "hipótese repressiva", hipótese reich-marcusiana, por assim dizer, vai ser contestada por Foucault: o poder não reprime, não oculta, revela a sua extensão e estratégias; o sexo não é castrado, ao contrário, incita-nos a falar dele e nele a todo momento. Toda instituição é muito mais constitutiva da sexualidade do que repressiva. Para melhor nos colocarmos, valemo-nos do comentário auspicioso de Lebrun: "Não é verdade que existia a infra-estrutura sexo, em cima da qual se construiria uma sexualidade que, finalmente, seria coroada por um poder repressivo (a Lei, os "tiras" dos costumes, as mamães castradoras, sei lá o que mais...) A verdade é exatamente o inverso: o sexo é uma objetivação da prática sexualidade, quer dizer, do conjunto dos efeitos produzidos nos corpos, nos comportamentos, nas relações sociais por algumas grandes estratégias de saber e poder. É o poder que produz a sexualidade, e esta lentamente delineou a imagem do sexo, que tomamos ingenuamente por uma idéia clara e distinta, bons cartesianos (ou bons freudianos) que somos" (LEBRUN, G. Passeios os léu. Ensaios. São Paulo: Brasiliense, 1983. p.80).

${ }^{84}$ FOUCAULT, M. História da Sexualidade II: o uso dos prazeres, p.13.
} 
o pensamento daquilo que ele pensa silenciosamente, e permitir-lhe pensar diferentemente" ${ }^{\natural 5}$. Ora, é justamente para pensar de maneira diferente que podemos vislumbrar os focos distintos apresentados no âmbito da problematização histórica.

Assim, a nossa postura sustenta que tanto a arqueologia quanto a genealogia se concentra como tarefa de "definir as condições nas quais o ser humano 'problematiza' o que ele é, e o mundo no qual ele vive" ${ }^{\Perp 86}$. Se há, porém, um certo distanciamento de consecução e alvo entre elas, cremos que será da ordem de uma fronteira punctilinear intersecional. Quer dizer, a arquegenealogia comporta um conjunto de interesses e ações coextensivas que encontram seus caminhos intercambiantes através dos pontos abertos desta fronteira que não é rígida. É assim, a nosso ver, que toda a possibilidade problematizada se encontra relacionada a um conjunto de práticas, que de maneira interconjugada, procura analisar, nos termos de Foucault, "as problematizações através das quais o ser se dá como podendo e devendo ser pensado, e as práticas a partir das quais essas problematizações se formam" ${ }^{\text {87. Mas }}$ justamente por se pensar em interconjugação é que devemos respeitar as diferenças que não vão acentuar exclusões na tarefa do pensamento histórico; diferentemente, porão à prova toda e qualquer problematização justamente por se tratar de uma história crítica. Assim, enquanto “a dimensão arqueológica da análise permite analisar as próprias formas da problematização;

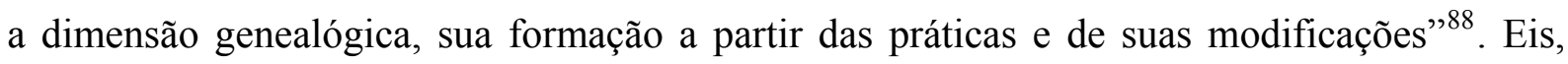
então, porque é possível falar em história serial, como já antepusemos; eis, mais ainda, porque são séries de pesquisas distintas que tecerão, pouco a pouco, a dimensão do conjunto da obra de Foucault. Como ele mesmo ressalta,

problematização da loucura e da doença a partir de práticas sociais e médicas, definindo um certo perfil de "normalização"; problematização da vida, da linguagem e do trabalho em práticas discursivas obedecendo a certas regras "epistêmicas"; problematização do crime e do comportamento criminoso a partir de certas práticas punitivas obedecendo a um modelo "disciplinar" [...] [problematizações] através de práticas de si, pondo em jogo os critérios de uma "estética da existência ${ }^{89}$.

\footnotetext{
${ }^{85}$ Ibidem, p. 14.

${ }^{86}$ Ibidem, Id. E aqui julgamos preciso o comentário de Deleuze ao ressaltar que, apesar de se colocar em correlação com a história, "Foucault nunca virou historiador. Foucault é um filósofo que inventa com a história uma relação inteiramente diferente que a dos filósofos da história. A história, segundo Foucault, nos cerca e nos delimita; não diz o que somos, mas aquilo que estamos em vias de diferir; não estabelece nossa identidade, mas a dissipa em proveito do outro que somos" (Cf. DELEUZE, G. Conversações. São Paulo: Editora 34, 1992 , p.119). Ao que nos parece, a genealogia enfatiza os tipos de valores sob os quais nossa subjetividade, de modo heterotópico, foi constituída e a partir de quais domínios e dispositivos podemos nos apropriar para nos diferir destes valores e, portanto, constituir uma subjetividade cujas margens não se cansam de mover e de expandir nossas delimitações.

${ }^{87}$ Ibidem. p. 15 .

${ }^{88}$ Ibidem, Id.

${ }^{89}$ Ibidem, p. 16.
} 
Levando isso em conta, vemos desenhar um campo cujo espaço de relação histórica se avoluma, cada vez mais, em direção a um trabalho de constante reformulação que não enceta nenhum tipo de acabamento. A rigor, o encontro da história com a filosofia haurida do pensamento de Foucault só é possível na medida em que arqueologia e genealogia se colocam em constante dinâmica com o propósito de elaborar "o trabalho crítico do pensamento sobre o próprio pensamento", que, por sua vez, "consiste em tentar saber de que maneira e até onde seria possível pensar diferentemente em vez de legitimar o que já se sabe" ${ }^{90}$. E isto não é de pouca monta quando colocamos em jogo os meios que temos para pensarmos as nossas experiências subjetivantes. Deste modo, é contra as possibilidades de qualquer tipo de legitimação que a genealogia não prescindirá das relações discursivas. Embora tal expressão marque a dimensão arqueológica, por vezes quase de maneira identitária, a genealogia não deixará de tocar o ponto do saber que acaba lhe garantindo a sua identidade verdadeira: o discurso; justamente para colocar a sua identidade em questão, ou seja, para pôr à prova o valor da história, o valor colocado na verdade da história da verdade. É assim, portanto, que, por ser tática, a genealogia, de uma vez por todas, defronta-se com a história da verdade. Mas, para tanto, tem de estabelecer a sua crítica à ordem histórica, que só ganha contornos em virtude do discurso e, neste ponto, verdade e discurso se imbricam.

Ora, é preciso, aqui, deixar claro de onde Foucault parte. Referimo-nos a uma suposição fundamental característica de seu pensamento:

suponho que em toda sociedade a produção do discurso é ao mesmo tempo controlada, selecionada, organizada e redistribuída por certo número de procedimentos que têm por função conjurar seus poderes e perigos, dominar seu acontecimento aleatório, esquivar sua pesada e temível materialidade ${ }^{91}$.

Devemos ressaltar que são os procedimentos as condições produzidas com o intuito de fazer valer um discurso qualquer. Deste modo, a interdição efetiva um tipo de procedimento que faz valer, sobretudo pelo fato de operar pela exclusão, os discursos que podem ou não ser reconhecidos como verdadeiros. Assim, "sabe-se bem que não se tem o direito de dizer tudo, que não se pode falar de tudo em qualquer circunstância, que qualquer um, enfim, não pode falar de qualquer coisa" ${ }^{\prime 2}$. Por conseguinte, decorre deste procedimento aquela separação encontrada entre o saber dominado no âmbito institucional e no âmbito da desqualificação,

\footnotetext{
${ }^{90}$ Ibidem, p.13.

${ }^{91}$ FOUCAULT, M. A ordem do discurso, p.09.

${ }^{92}$ Ibidem, Id.
} 
quer dizer, a separação deflagra o processo discursivo que se principia na verdade, isto é, no conjunto de procedimentos, falas, normas, regras, práticas que reconhecem o falso distintamente do verdadeiro, conforme o que se pode dizer, por quem diz e quando se diz. Fato este, por exemplo, encontrado na loucura, já que "o louco é aquele cujo discurso não pode circular como o dos outros"93. Daí o fato de, incansável recorrência, o filósofo pensar nas práticas. A instituição, materialização da prática não discursiva, incorpora o discurso de forma bruta, pois, além de identificar os sujeitos, os segrega, os separa, os restringe. Isto significa dizer que a verdade não se dá numa pureza ontológica. Além, é claro, de necessitar do canal móvel de toda discursividade para fazer com que a fala seja reconhecida e dita por meio de um discurso que possa ser reconhecido como verdadeiro, a verdade também "apóiase sobre um suporte institucional: é ao mesmo tempo reforçada e reconduzida por todo um compacto conjunto de práticas" 94 . A verdade, então, é imanente à ordem dos enunciados discursivos e não discursivos, e das práticas aduzidas do espaço que esta ordem produz.

É evidente, e não poderia deixar de ser diferente, que a verdade sob a qualificação discursiva não pode abrir mão de uma relação de poder, já que vai criando determinados campos sobre os quais as relações históricas podem ser vistas como verdadeiras. Contudo haveremos de levar em consideração que

\begin{abstract}
a verdade é deste mundo; ela é produzida nele graças a múltiplas coerções e nele produz efeitos regulamentados de poder. Cada sociedade tem seu regime de verdade, sua "política geral" de verdade: isto é, os tipos de discursos que ela acolhe e faz funcionar como verdadeiros; os mecanismos e as instâncias que permitem distinguir enunciados verdadeiros dos falsos, a maneira como se sanciona uns e outros; as técnicas e os procedimentos que são valorizados para a obtenção da verdade; o estatuto daqueles que têm o encargo de dizer o que funciona como verdadeiro ${ }^{95}$.
\end{abstract}

De nossa parte, então, a genealogia opera como elemento histórico capaz de revelar a verdade posta na engrenagem do mundo real, ou seja, neste mundo que possui uma história e que faz circular os feitos e efeitos humanos a partir de verdades consignadas a uma série de condições e estruturas autorizadas historicamente, de modo a produzir e regulamentar a própria verdade. Com isso, é inevitável que se estabeleça uma relação de forças, ou melhor, de poder, porque "não nos encontramos no verdadeiro senão obedecendo às regras de uma 'polícia' discursiva que devemos reativar em cada um de nossos discursos" $" 96$. Conseqüentemente, na história, podemos encontrar uma vontade de verdade de constante reposição. Todavia nela também

\footnotetext{
93 Ibidem, p.10.

${ }^{94}$ Ibidem, p.17.

${ }^{95}$ FOUCAULT, M. Verdade e poder. In. Microfísica do poder, p.12.

${ }^{96}$ FOUCAULT, M. A ordem do discurso, p. 35.
} 
haverá uma contra-força, potência que deseja incendiar por dentro a própria verdade, que vem pela crítica da genealogia contra toda verdade. Se, numa direção, a história "só aparece aos nossos olhos", sob os termos de Foucault, como "uma verdade que seria riqueza, fecundidade, força doce e insidiosamente universal"; a genealogia, em contrapartida, quer fazer aparecer o que ignoramos: a "prodigiosa maquinaria destinada a excluir todos aqueles que, ponto por ponto, em nossa história, procuraram contornar essa vontade de verdade e recolocá-la em questão contra a verdade" $" 97$.

Não sem sentido, Foucault nos dirá que a "genealogia exige, portanto, a minúcia do saber, um grande número de materiais acumulados, exige paciência" ${ }^{98}$. Este conjunto de exigências faz-se necessário devido à própria demanda genealógica: evidenciar alguns elementos para que a história empreenda uma libertação dos saberes históricos, até então sujeitados sob determinadas formas discursivas, pois "somos julgados, condenados, classificados, obrigados a desempenhar tarefas e destinados a um certo modo de viver ou morrer em função dos discursos verdadeiros que trazem consigo efeitos específicos de poder" 99 . Decorrência bruta: a história não é impune e não vivemos sob a sua tutela impunemente. Ao indagar pelos sistemas de sujeição discursiva, práticos ou não, a genealogia traz à luz os jogos de verdade que se encontram no esteio de uma história da verdade.

Mas qual é o entendimento dado à noção de jogo de verdade? Ela se define a partir da própria concepção da verdade. No entanto, por jogo, devemos entender "um conjunto de regras de produção da verdade" ${ }^{100}$ que ocupa e faz preencher uma determinada produção do discurso, fixando-lhe uma identidade que tem forma, localização e campo de atuação. Além disso, este conjunto de regras se encontra situado em certos procedimentos que "conduzem a um certo resultado, que pode ser considerado em função de seus princípios e de suas regras de produção"101. A genealogia persegue "quem" compõe o jogo de verdade: quem alavancou a verdade? Um grupo, um indivíduo, um conjunto de controles de produção do discurso? Definir o jogo, no sentido de colocá-lo à mostra, forjar-lhe uma história, é levar em consideração a multiplicidade de jogos de verdade que permeia as condições de funcionamento dos discursos: a identidade da regra do que é dito; o seu pronunciamento; os sujeitos que falam e não podem falar, já que "ninguém entrará na ordem do discurso se não

\footnotetext{
97 Ibidem, p.20.

${ }^{98}$ FOUCAULT, M. Nietzsche, a genealogia e história. In. Microfísica do poder, p.15.

${ }^{99}$ FOUCAULT, M. Soberania e disciplina. In. Microfísica do Poder, p.180.

${ }^{100}$ FOUCAULT, M. L'éthique du souci de soi comme pratique de la liberté. Dits et Écrits IV, No 356, 1984, p.725.

${ }^{101}$ Ibidem, Id.
} 
satisfizer a certas exigências ou se não for, de início, qualificado para fazê-lo" ${ }^{\text {102 }}$; os rituais que definem as falas, ou melhor, a qualificação que devem possuir os indivíduos que falam; que definem "os gestos, os comportamentos, as circunstâncias, e todo o conjunto de signos que devem acompanhar o discurso"103; enfim, o que nos leva a responder a indagação fundamental: quem diz a verdade? Contudo, ao se debruçar sobre ela, a genealogia opera, exercendo a sua crítica, levando em consideração que "sempre há a possibilidade num jogo de verdade dado de descobrir alguma outra coisa e de mudar mais ou menos tal e tal regra, e, algumas vezes, todo o conjunto do jogo de verdade"104. Com isso, evidentemente, a genealogia não faz da busca histórica uma reprodução a partir de suas verdades nem quer deixar no sussurro milenar das pegadas anônimas o traço invisível que se perdeu na vertigem da história, mas intenta fazer de suas marcas os traços conseqüentes que ainda persistem no espaço do que somos.

Posto assim, a genealogia não quer reproduzir uma forma transparente de verdade que estaria presente em qualquer tipo de conhecimento histórico aguardando o seu esgotamento. Muito menos pretende determinar qualquer tipo de conhecimento a repousar no fundo daquela transparência. Ora, quando falamos em jogo, temos em mente, sobretudo, as condições de forças que não são deterministas da história, mas que se conjugaram numa especificidade qualquer, a fim de dar ao ser histórico uma composição que somente se deu por experiência. Se é assim, todas as formas históricas concebidas por intermédio da noção de jogo de verdade podem ser pensadas sob as diferentes nuances das condições de forças. Somos, daí, autorizados a pensar numa

história que não seria aquela do que poderia haver de verdadeiro nos conhecimentos; mas uma análise dos 'jogos de verdade', dos jogos entre o verdadeiro e o falso, através dos quais o ser se constitui historicamente como experiência, isto é, como podendo e devendo ser pensado ${ }^{105}$.

Outrossim, não nos surpreenderia o fato de Foucault situar o projeto de sua obra neste campo de relações, isto é, a partir da história que indaga de modo genealógico o valor da verdade

\footnotetext{
${ }^{102}$ FOUCAULT, M. A ordem do discurso, p.37.

${ }^{103}$ Ibidem, p.39.

${ }^{104}$ FOUCAULT, M. . L'éthique du souci de soi comme pratique de la liberté. Dits et Écrits IV, № 356, 1984, p.725-726.

${ }^{105}$ FOUCAULT, M. História da Sexualidade II: o uso dos prazeres, p.12. A nosso ver, Wahl acerta a mão ao dizer que a análise dos jogos de verdade é uma "maravilhosa formulação onde se marca toda a diferença: não a verdade como a especulação a coloca, antes (e ao lado da) experiência, mas como ela se exerce nas práticas e através de sua interpretação" (WAHL, F. Hors ou dans la philosophie? L'Archeologie du savoir, L'Usage des plaisirs, Le Souci de soi. In: Michel Foucault Philosophe: Rencontre Internationale. Paris, 9, 10, 11 janvier 1988. Paris, Seuil 1989, p.91.)
} 
sedimentado, oxidado e situado naquilo e daquilo que se pode dizer. Revirar o campo sedimentado, eliminar a oxidação, recompor o que se situou desde longe como valor verdadeiro é possível, tão somente, pelas lentes da genealogia que se põe a indagar sob a seguinte ótica:

através de quais jogos de verdade o homem se dá seu ser próprio a pensar quando se percebe como louco, quando se olha como doente, quando reflete sobre si como ser vivo, ser falante e ser trabalhador, quando ele se julga e se pune enquanto criminoso? Através de quais jogos de verdade o ser humano se reconheceu como homem de desejo? ${ }^{106}$

Seria possível indicar que o tema do jogo de verdade, dado sob este delineamento, começa a suscitar uma outra dimensão temática, porém pertinente à genealogia, a saber, a da experiência originária do ser que se constitui historicamente. Experiência originária, sobretudo, referente ao conhecimento da verdade. Aqui é preciso admitir "que o que dá acesso à verdade, as condições segundo as quais o sujeito pode ter acesso à verdade, é o conhecimento, e o conhecimento somente" e, com isso, admitir um problema que se coloca ao conhecimento da verdade, já que a "história da verdade", na perspectiva foucaultiana, “começa no momento em que o que permite aceder ao verdadeiro é o próprio conhecimento e somente ele" ${ }^{107}$. Impõe-se a toda possibilidade do conhecer histórico, de maneira subtendida, a indagação pelo preço pago aos modos de objetivação e subjetivação que fazem e fizeram valer as condições históricas existentes dadas ao pensamento. A genealogia que Foucault faz operar, assim, busca alargar os horizontes das possíveis experiências originárias que podem ser focadas de múltiplas formas ao conhecimento, no entanto atrelado a um trabalho histórico. São esclarecedoras os seguintes termos:

minha questão é esta: sob qual preço o sujeito pode dizer a verdade sobre ele mesmo? Sob qual preço o sujeito pode dizer a verdade sobre ele mesmo enquanto louco? Como se pode dizer a verdade sobre o sujeito doente? Como se pode dizer a verdade sobre o sujeito louco? Sob qual preço se pode problematizar e analisar o que é o sujeito que fala, o sujeito que trabalha, o sujeito que vive? Como dizer a verdade sobre si mesmo

\footnotetext{
${ }^{106}$ Ibid. id. Como faz Gros, é interessante fazer notar que Chartier também elege o jogo de verdade como "o princípio fundamental de organização da obra" de Foucault, donde seria possível fazer uma leitura "retrospectivamente dada à questão do verdadeiro e do falso" (CHARTIER, R. Au bord de la falaise: l'histoire entre certitudes et inquietude. Paris: Albin Michel, 1998, p.205). Contudo julgamos que o jogo de verdade opera menos como um princípio fundamental de organização da obra do que o que está posto no próprio valor que se busca em relação à verdade na história. Ao que nos parece, esta abordagem é possível se nos posicionamos ao lado dos efeitos que a verdade produz na constituição da subjetividade; mas, se nos colocamos ao lado das causas, buscamos o que efetivou a verdade, ou seja, buscamos pelas condições históricas.

${ }^{107}$ FOUCAULT, M. A hermenêutica do sujeito, p.22.
} 
enquanto que se pode ser um sujeito criminal? Como o sujeito pode dizer a verdade sobre ele mesmo enquanto sujeito de prazer sexual, e sob que preço? ${ }^{108}$

$\mathrm{Na}$ nossa interpretação, as respostas estão impressas no decurso do desenvolvimento desta problemática que se repõe, fazendo circular história e subjetividade coextensivamente. Assim, não se trata de revelar tão somente o preço teórico a partir do que a relação com a verdade se impõe. Muito mais do que isso, é preciso mostrar que o preço a ser pago à história da verdade é o que está vinculado ao louco, interno, demente, transgressor, atravessados pelo discurso da verdade, desde então, constituídos como o outro absoluto, fenômeno superficial de um sistema de operações subterrâneas que não podem ficar desconhecidas. Eis, para tanto, a história que evidencia o preço institucional a ser pago: a organização dos espaços se dá em função da organização da verdade e de seus anúncios; espaço, regime de verdades em pura visibilidade.

De nossa parte, acreditamos que tanto o foco da arqueologia quanto o da genealogia se concentram mutuamente para "tentar perceber como se realizou, mas também se repetiu, se reconduziu, se deslocou essa escolha da verdade no interior da qual nos encontramos, mas que renovamos continuamente" ${ }^{109}$. Dessa forma, um ponto a ser ressaltado é a crítica que advém da arqueologia, que se posiciona com o intuito de procurar cercar as formas da exclusão, da limitação, da apropriação da verdade, certamente a fim de "mostrar como se formaram, para responder a que necessidades, como se modificaram e se deslocaram, que forças exerceram efetivamente, em que medida foram contornadas" ${ }^{\prime 10}$, ao passo que o conjunto genealógico se defronta com os princípios que "se formaram, através, apesar, ou com o apoio desses sistemas de coerção, séries de discursos; qual foi a norma específica de cada uma e quais foram suas condições de aparição, de crescimento, de variação"111. Mas não nos soam, na verdade, como tons parecidos? Certamente que sim. O método arqueológico não pode prescindir da tática da genealogia. Foucault, mais do que ninguém, possuía uma arguta consciência deste aspecto e sentenciava: "entre o empreendimento crítico e o empreendimento genealógico, a diferença não é tanto de objeto ou de domínio mas, sim, de ponto de ataque, de perspectiva e

\footnotetext{
${ }^{108}$ FOUCAULT, M. Structuralisme et poststructuralisme, Dits et Écrits IV, $\mathrm{N}^{\circ}$ 330, 1983, p.442-443. Fato curioso e não despiciendo é apontado por Gros na Situation du cours referente ao curso A hermenêutica do sujeito, proferido por Foucault (1981-1982), em que revela uma passagem inédita do manuscrito que serviria ao filósofo de suporte para seu curso. Chamamos a atenção para o seu primeiro aspecto: "Três questões que de uma certa maneira vão atravessar todo o pensamento ocidental: - o acesso à verdade; - a articulação do sujeito por ele mesmo no cuidado (souci) que ele tem de si; - o conhecimento de si” (Cf. FOUCAULT, M. L'Herméneutique du sujet. Paris: Gallimard, 2001. In. Situation du cours, p.504). O acesso à verdade é, ao que nos parece, a grande questão de valor que promana de toda problematização genealógica. Além do fato de que assinala, como marca indefectível, o pensamento ocidental que, de fio a pavio, Foucault vem tematizando.

${ }^{109}$ FOUCAULT, M. A ordem do discurso, p.62.

${ }^{110}$ Ibidem, p.60.

${ }^{111}$ Ibidem, p.60-61.
} 
delimitação" "112, mas não sem antes ter partido da séria constatação: "na verdade, estas duas tarefas não são nunca inteiramente separáveis" ${ }^{113}$.

Sendo assim, podemos sustentar que a genealogia responde à dimensão da história crítica do pensamento com a mesma força e necessidade que responde a arqueologia. Postas em ligação com o descortinar histórico que se ergue ao passo e ao preço das relações discursivas que circularam a verdade, deflagram a operação crítica para que o pensamento, condenado ao acesso da verdade, empreenda a sua própria história, não, porém, sem deixar de pagar o preço atinente a esta descoberta. Então, e por isso mesmo,

a crítica vai se exercer [...] como investigação histórica através dos acontecimentos que nos têm levado a nos constituir, a nos reconhecer como sujeitos do que nós fazemos, pensamos, dizemos. Nesse sentido, esta crítica não é transcendente, e não tem por finalidade tornar possível uma metafísica: ela é genealógica em sua finalidade e arqueológica em seu método. Arqueológica - e não transcendental - no sentido em que ela não procurará liberar as estruturas universais de todo conhecimento ou de toda ação moral possível; mas a tratar os discursos que articulam o que nós pensamos, dizemos e fazemos na mesma proporção dos acontecimentos históricos. E esta crítica será genealógica no sentido em que ela não deduzirá da forma do que nós somos o que nos é impossível de fazer ou de conhecer; mas ela liberará da contingência que nos tem feito ser o que nós somos, a possibilidade de não mais ser, fazer ou pensar o que nós somos, fazemos ou pensamos ${ }^{114}$.

Desse ponto de vista, é possível entender o motivo pelo qual Foucault alega que as tarefas arqueológica e genealógica, engrenagens conjuntas da história crítica do pensamento, não podem ser inteiramente separáveis. Não obstante, para nós, fica patente que o foco para o qual tais tarefas estão direcionadas vai ao encontro da dilatação de uma série de problemáticas que se situam no campo histórico contingencial. Assim, ao se dirigir à contingência como tática, a genealogia se coloca em operação para reencontrar as diferentes cenas que exerceram papéis distintos em toda contingência histórica e, com isso, a genealogia "se opõe aos desdobramentos meta-históricos das significações ideais e das indefinidas teleologias". Ademais, ela instilará na história a persistente interrogação sobre a obscura memória que acompanha o surgimento das coisas. Onde tudo não passava de retorno sobre si mesmo, a

\footnotetext{
${ }^{112}$ Ibidem, p.66-67.

${ }^{113}$ Ibidem, p.66. Para melhor ressaltar a importância da dinâmica existente entre arqueologia e genealogia, remetemos o leitor para esta irrefutável passagem de Foucault, quanto a este ponto: "Assim, as descrições críticas e as descrições genealógicas devem alternar-se, apoiar-se umas nas outras e se completarem. A parte crítica da análise liga-se aos sistemas de recobrimento do discurso; procura detectar, destacar esses princípios de ordenamento, de exclusão, de rarefação do discurso. Digamos, jogando com as palavras, que ela pratica uma desenvoltura aplicada. A parte genealógica da análise se detém, em contrapartida, nas séries da formação efetiva dos discursos: procura apreendê-lo em poder de afirmação, e por aí entendo não um poder que se oporia ao poder de negar, mas o poder de constituir domínios de objeto, a propósito dos quais se poderia afirmar ou negar proposições verdadeiras ou falsas". Ibidem, p.69-70.

${ }^{114}$ FOUCAULT, M. Qu'est-ce que les Lumières? Dits et Écrits IV, No 339, 1984, p.574.
} 
genealogia torna a história pródroma, isto é, sinal anunciador que se coloca ao pensamento como primeiros indícios de algo que ainda é vir-a-ser. Portanto a genealogia, acrescenta Foucault, "se opõe à pesquisa da 'origem"”115.

Ao colocar, todavia, a origem em cena, o filósofo da descontinuidade histórica elaborará um profundo trabalho de recusa, concentrado em determinados postulados concernentes à tal problemática. Associada a esta empreitada, estará o aprofundamento das rupturas históricas arquitetadas desde a mais incipiente tarefa arqueológica. Para tanto, Foucault se valerá da interpretação-apropriação que faz do pensamento de Nietzsche, especificamente quanto à noção de genealogia, sobretudo com o intuito de marcar melhor o objeto próprio da genealogia em sua perspectiva, é dizer, ao seu modo. Trata-se, neste caso, da análise que Foucault faz dos termos Ursprung para origem, Herkunft para proveniência e Entstehung para emergência ${ }^{116}$.

O valor da verdade que Foucault faz vir a lume tem em sua postura de refutação dos postulados da origem um papel, mais do que nunca, de fundamental importância. Levando em consideração que a verdade e o seu reino, não poderíamos deixar de escapar do argumento os seus jogos de verdade, tiveram sua história na história, quando, ademais, se concebe a história a partir de uma perspectiva originária, a verdade, nos termos de Foucault, embora "espécie de erro que tem a seu favor o fato de não poder ser refutada, sem dúvida porque o longo cozimento da história a tornou inalterável” ${ }^{\text {"17 }}$, continuará a induzir o pensamento aos erros históricos fundamentais ${ }^{118}$. Para que isto não ocorra, com efeito, “o genealogista necessita da

\footnotetext{
${ }^{115}$ FOUCAULT, M. Nietzsche, a genealogia e história. In. Microfísica do poder, p.16.

${ }^{116}$ É preciso, a essa altura, sublinhar, mais uma vez, o modo pelo qual Foucault abordava o pensamento de outros filósofos, isto é, como instrumentalizava o que é de seu interesse, como indicamos inicialmente na nota 126 do capítulo 1 de nosso trabalho. Sem a pretensão de querer ser comentador ou fiel exegeta, apropriava-se aberta e reconhecidamente do pensamento de outros filósofos como instrumentos de pensamento (instruments de pensée). A expressão possui data tardia, o que revela, de acordo com o nosso juízo, uma postura marcante do filósofo, e pode ser encontrada numa entrevista de 29 de maio de 1984, quase dois meses antes de sua morte, intitulada Le retour de la morale (cf. Dits et Écrits IV, No 354, 1984, p.696-707). Nela, deparamo-nos com a seguinte trama: "todo o meu futuro filosófico foi determinado pela minha leitura de Heidegger. Mas eu reconheceria que foi Nietzsche que prevaleceu" (p.703). Então, a seguir, Foucault acrescenta: "Talvez eu escreva sobre eles um dia, mas até o momento eles somente serão para mim instrumentos de pensamento" (p.703). Assim, ao tratarmos dos termos essencialmente advindos do pensamento de Nietzsche, não o fazemos no intuito de situá-los dentro de sua filosofia, contudo o fazemos a partir da interpretação colocada pelo próprio Foucault, ou melhor, a partir da maneira pela qual este utilizou o pensamento de Nietzsche como instrumento para fazer operar, ao seu modo, a sua tática genealógica. Ainda nesta direção, é de extrema valia o comentário de Marton: "Talvez Foucault encare Nietzsche menos como objeto de análise do que como instrumento; talvez se relacione com ele menos como o comentador com seu interpretandum do que como o pensador com sua caixa de ferramentas". MARTON, S. Extravagâncias: ensaios sobre a filosofia de Nietzsche. São Paulo: Discurso Editorial e Ijuí, Editora Ijuí, 2000, p.170.

${ }^{117}$ FOUCAULT, M. Nietzsche, a genealogia e história. In. Microfísica do poder, p.19.

${ }^{118}$ Quando Deleuze afirma que "a verdade é inseparável de um procedimento que a estabeleceu" (cf. DELEUZE, G. Foucault. Paris: Éditions de Minuit, 1986, p.70), acaba por ressaltar o aspecto fundamental situado na base da verdade, tal como Foucault quer trabalhar, com a finalidade de que a história não mais confunda "ser e
} 
história para conjurar a quimera da origem"119 e, daí, permitir que uma nova valoração acerca da própria verdade tenha visibilidade para que o pensamento saiba avaliar as próprias avaliações históricas que estipularam certos critérios e valores também históricos, em contrapartida, utilizando novas perspectivas ou critérios. Todavia, para que isso ocorra, três postulados da origem, por assim dizer, são suspensos, ou melhor, recusados pelo trabalho do genealogista.

Nesse ponto, Foucault nos apresenta uma indagação-resposta crucial:

se o genealogista tem o cuidado de escutar a história em vez de acreditar na metafísica, o que é que ele aprende? Que atrás das coisas há "algo inteiramente diferente": não seu segredo essencial e sem data, mas o segredo que elas são sem essência, ou que sua essência foi construída peça por peça a partir de figuras que lhe eram estranhas ${ }^{120}$.

Ora, não nos custa muito perceber que Foucault persegue, de fio a pavio, essas figuras estranhas, dantes totalmente renegadas à primazia da ciência História, porém, agora emersas como peças fundamentais para a compreensão do que fazemos, pensamos e somos. O que está em jogo é um outro tipo de história que atravessa a História. Mas tal intento se põe em marcha somente na proporção em que o fundamento originário passa a ser recusado como condutor de toda verdade histórica.

Assim, numa primeira instância, Foucault rejeita a história calcada na busca de uma origem (Ursprung) porque "a pesquisa, nesse sentido, se esforça para recolher nela a essência exata da coisa, sua mais pura possibilidade, sua identidade cuidadosamente recolhida em si mesma, sua forma imóvel e anterior a tudo o que é externo, acidental, sucessivo" ${ }^{21}$. De fato, isto era essencial para se forjar uma continuidade histórica, ou seja, mostrar e se mover na tentativa de encontrar o sentido inequívoco dos encadeamentos históricos. No entanto, quando a genealogia direciona a sua lente de aumento para a origem, não deixa transparecer nenhuma dúvida de que ela não possui fonte limpa ou forma de dimensões exatas a se encaixar numa representação qualquer. Na verdade, “o que se encontra no começo histórico das coisas não é a identidade ainda preservada da origem - é a discórdia entre as coisas, é o disparate"122.

representar como se eles fossem equivalentes, como se um desenho fosse o que ele representa" (cf. FOUCAUlT, M. Ceci n'est pas une pipe. Dits et Écrits I, No 53, 1968, p.636). Então, voltando-se contra a quimera da origem, Foucault revelaria que, sob a ótica de Deleuze, "o verdadeiro não se define nem por uma conformidade ou uma forma comum, nem por uma correspondência entre as duas formas. Há uma disjunção entre falar e ver, entre o visível e o enunciado: o que se vê jamais se aloja no que se diz". (Opus cit. p.71).

${ }^{119}$ FOUCAULT, M. Nietzsche, a genealogia e história. In. Microfísica do poder, p.19.

${ }^{120}$ Ibidem, p.17-18.

121 Ibidem, p. 17.

${ }^{122}$ Ibidem, p. 18. 
E por ser inevitável o encontro com o desatino, por exemplo, com a Não-Razão, que "formava um tipo de perigo aberto em que as ameaças poderiam, ao menos juridicamente, comprometer as relações de subjetividade e da verdade"123 de uma Razão, a história, em sua tática genealógica, ensina, na expressão de Foucault, "a rir das solenidades da origem"124. Assim, numa segunda instância, Foucault rejeita a alta origem das coisas, a nobreza de um princípio que, depositado num fato primeiro e inaugural, pudesse selar os fatos históricos que de sua origem, porventura, proviessem. Embora seja mais conveniente "acreditar que as coisas em seu início se encontravam em estado de perfeição; que elas saíram brilhantes das mãos do criador, ou na luz sem sombra da primeira manhã" ${ }^{125}$, a genealogia, contudo, irá se mover no sentido de mostrar que o começo histórico é baixo. De acordo com Foucault, "não no sentido de modesto ou de discreto como o passo da pomba, mas de derrisório, de irônico, próprio a desfazer todas as enfatuações" ${ }^{126}$. A história não é mais a face cristalina da superfície do lago, em espelho, para refletir a beleza do próprio homem; a história é, desde a mais superficial face, turva; e, se reflete alguma imagem, será a de feridas inextinguíveis e cruéis: "o homem começou pela careta daquilo em que ele ia se tornar" ${ }^{\prime 27}$.

Sendo assim, uma nova perspectiva abre-se, pois uma outra postura é exigida na compreensão do que se tornará, finalmente, a quimera da origem. Esta sempre teve a pretensão de ser a emanação da verdade. Vista, no entanto, como "ponto totalmente recuado e anterior a todo conhecimento positivo, ela tornará possível um saber que, contudo, a recobre e não deixa, na sua tagarelice, de desconhecê-la" ${ }^{\text {128 }}$, seguramente pelo fato de a origem ser tão somente uma interpretação não acabada, uma vez que "ela estaria nesta articulação inevitavelmente perdida onde a verdade das coisas se liga a uma verdade do discurso que logo a obscurece, e a perde" ${ }^{129}$. Mas, ao ser relacionada ao discurso, a origem se torna interpretação; e, na medida em que se torna interpretação, há uma interdição ao significado original, porque quem propôs a interpretação, a que prevaleceu e venceu, fez circular a predominância de um sentido verdadeiro que, para existir, teve de entregar ao sacrifício outros

\footnotetext{
${ }^{123}$ FOUCAULT, M. Histoire de la Folie, p. 70.

${ }^{124}$ FOUCAULT, M. Nietzsche, a genealogia e história. In. Microfísica do poder, p.18.

125 Ibidem, Id.

${ }^{126}$ Ibidem, Id.

127 Ibidem, Id. Em Nietzsche, Freud e Marx, Foucault menciona três grandes feridas narcisistas na cultura ocidental: "a ferida imposta por Copérnico; a feita por Darwin, quando descobriu que o homem descendia do macaco; e a ferida ocasionada por Freud quando ele mesmo, por sua vez, descobre que a consciência nasce da inconsciência" (p.17). Ora, na mesma linha argumentativa, poderíamos supor que Foucault dilacera ainda mais esse núcleo de feridas ao desenvolver um conjunto de análise histórica que não mais nos permitirá falar de nossa origem, de uma matriz potencializadora da conjugação humana. Quanto mais homens históricos, mais distantes de nós mesmos nos encontraremos. A nossa história não é uma grande verdade, portanto.

128 Ibidem, Id.

129 Ibidem, p.18-19.
} 
sentidos, donde "o princípio de interpretação não é mais do que o intérprete" ${ }^{130}$. Por conseguinte, o último postulado a ser rejeitado referente à Ursprung é o do lugar da verdade. Desde então, somos autorizados a pensar que

fazer a genealogia dos valores, da moral, do ascetismo, do conhecimento não será, portanto, partir em busca de sua "origem", negligenciando como inacessíveis todos os episódios da história: será, ao contrário, se demorar nas meticulosidades e nos acasos dos começos; prestar uma atenção escrupulosa à sua derrisória maldade; esperar vê-los surgir, máscaras enfim retiradas, com o rosto do outro; não ter pudor de ir procurá-las lá onde elas estão, "escavando os bas-fonds"; deixar-lhes o tempo de elevar-se do labirinto onde nenhuma verdade as manteve jamais sob sua guarda ${ }^{131}$.

Por certo, é tendo em mente esse "rosto do outro" que podemos entender a condução existente da história crítica do pensamento. História, aliás, que não se fixa, nem se justifica num movimento de retroação; ao contrário, pela lente da genealogia, pois que não se prescinde mais da interpretação, "a história, com suas intensidades, seus desfalecimentos, seus furores secretos, suas grandes agitações febris como suas síncopes, é o próprio corpo do vir-a-ser"132. Desse ponto de vista, então, Foucault nos conduz a um bom termo: “é preciso ser metafísico para lhe procurar uma alma na idealidade longínqua da origem"133.

$\mathrm{O}$ rigor da crítica que vemos Foucault estabelecer à origem prepara o campo para a análise e investigação dos termos proveniência (Herkunft) e emergência (Entstehung), que colocam em jogo uma outra perspectiva na forma pela qual os objetos históricos serão constituídos geneticamente. Se, de forma ordinária, Herkunft e Entstehung puderam ser tomados como correlativos de origem, isso se deveu ao fato de a história, sob os mantos da verdade, não ter permitido a reconstituição da própria articulação da história da verdade, uma vez que estava assimilada pelos vícios que conduziam o pensamento na busca de uma origem fundante qualquer. Mas, sob a dimensão da genealogia, a tomada de tais termos concorre para a reconstituição e recolocação do próprio papel da história, por conseguinte, das formas pelas quais o pensamento permite conhecer determinado objeto e, no mesmo nível, fazer-se conhecer como objeto.

Podemos constatar, assim, uma mudança de direção e de propósito. A princípio, a genealogia toma a proveniência a partir de um entrocamento de fatos, perspectivas, forças que afastam qualquer possibilidade de identidade ou de fundo original. Dessa maneira, a Herkunft, nos termos de Foucault,

\footnotetext{
${ }^{130}$ FOUCAULT, M. Nietzsche, Freud e Marx, p.26.

${ }^{131}$ FOUCAULT, M. Nietzsche, a genealogia e história. In. Microfísica do poder, p.19.

${ }^{132}$ Ibidem, p. 20.

${ }^{133}$ Ibidem, Id.
} 
não se trata de modo algum de reencontrar em um indivíduo, em uma idéia ou um sentimento as características gerais que permitiram assimilá-los a outros - e de dizer: isto é grego ou isto é inglês; mas de descobrir todas as marcas sutis, singulares, subindividuais que podem se entrecruzar nele e formar uma rede difícil de desembaraçar; longe de ser uma categoria da semelhança, tal origem permite ordenar, para colocá-las a parte, todas as marcas diferentes ${ }^{134}$.

Aqui, o que faz pesar o sentido da busca de todo o entrecruzamento, presente na proveniência do plano histórico, é o fato de a análise calcada na proveniência permitir, como marca fundamental, a dissociação de um $E u$ que, agora, pulula numa multiplicidade sem fim em lugares e recantos distintos, porém não mais associado a uma origem. A admissão dessa perspectiva, ao que nos parece, já está contida na crítica do documento, postura fundamental inerente ao método arqueológico que provocou um colapso na certeza de que o objeto histórico seria dado ao pensamento e de que atingi-lo permitiria ao pensamento o acesso tranqüilo a toda verdade.

Além disso, a proveniência permitirá que a genealogia reencontre "sob o aspecto único de um caráter ou de um conceito a proliferação dos acontecimentos através dos quais (graças aos quais, contra os quais) eles se formaram"135. Contudo, ao buscar a formação dos acontecimentos, o que equivale a pensar em constituição e meios para intermediar a visibilidade de cada acontecimento, não podemos perder de vista a ruptura fundamental já colocada na história pelas conseqüências advindas da arqueologia, notadamente sob as condições de descontinuidades que pairam sobre a própria história. Então, calcados nas considerações de Foucault, constatamos que

a genealogia não pretende recuar no tempo para restabelecer uma grande continuidade para além da dispersão do esquecimento; sua tarefa não é a de mostrar que o passado ainda está lá, bem vivo no presente, animando-o ainda em segredo, depois de ter imposto a todos os obstáculos do percurso uma forma delineada desde o início. Nada que se assemelhasse à evolução de uma espécie, ao destino de um povo. Seguir o filão complexo da proveniência é, ao contrário, manter o que se passou na dispersão que lhe é própria: é demarcar os acidentes, os ínfimos desvios - ou ao contrário as inversões completas - os erros, as falhas na apreciação, os maus cálculos que deram nascimento ao que existe e tem valor para nós; é descobrir que na raiz daquilo que nós conhecemos e daquilo que nós somos - não existe a verdade e o ser, mas a exterioridade do acidente ${ }^{136}$.

Vista sob essa dimensão, a genealogia não repara a potência de uma história que se codificou em um ato qualquer. Ao contrário, a exterioridade é justamente o aspecto mais acidental da

\footnotetext{
${ }^{134}$ Ibidem, Id.

${ }^{135}$ Ibidem, p.20-21.

${ }^{136}$ Ibidem, p. 21.
} 
história, quer dizer, é a força exercida pela interpretação que capta e coloca em cena o que não possui finalidade definida. Fato, portanto, que situa a Herkunft, forçosamente, numa perspectiva crítica: ela parte do princípio de que a mais vertiginosa e profunda linha histórica "não é senão um jogo e uma ruga da superfície"137. Notemos aí o aspecto crítico principiado na arqueologia: é a ação deliberada do historiador que faz emergir a própria história, isto é, essa persistente exterioridade acidental que não carrega nenhuma essência ou finalidade a ser cumprida: a história não alcança o acontecimento inaugural, no limite, resvala um conjunto de falhas, de fissuras, de camadas heterogêneas e heterotópicas que a tornam instável. Por conseguinte, defrontamo-nos com a seguinte constatação: "a pesquisa da proveniência não funda, muito pelo contrário: ela agita o que se percebia imóvel, ela fragmenta o que se pensava unido; ela mostra a heterogeneidade do que se imaginava em conformidade consigo mesmo" 138 .

Além da perspectiva da exterioridade do acidente, entretanto, a proveniência expressa a superação da história metafísica na medida em que toma o corpo como a mais palpável superfície de inscrição dos acontecimentos. A rigor, o desenvolvimento da obra de Foucault passa e toca o corpo como superfície dos acontecimentos que foram e continuam sendo inscritos sobre eles: loucura, demência, doença e anormalidade, castigo, punição, violação e dilaceração do corpo - afinal, quem é Pierre Rivière? quantos são? - controle da vida, biopoder, sexualidade: jogos de produção de subjetividade cujos corpos são flexionados numa maquinaria de jogos de verdade. Pois bem, o corpo é o lugar da Herkunft, território imanente da subjetividade. Tanto é que as seguintes dimensões nos auxiliam neste entendimento:

o corpo - e tudo o que diz respeito ao corpo, a alimentação, o clima, o solo - é o lugar da Herkunft: sobre o corpo se encontra o estigma dos acontecimentos passados do mesmo modo que dele nascem os desejos, os desfalecimentos e os erros; nele também eles se atam e de repente se exprimem, mas nele também eles se desatam, entram em luta, se apagam uns aos outros e continuam seu insuperável conflito ${ }^{139}$.

\footnotetext{
${ }^{137}$ FOUCAULT, M. Nietzsche, Freud e Marx, p.19.

${ }^{138}$ FOUCAULT, M. Nietzsche, a genealogia e história. In. Microfísica do poder, p.21.

139 Ibidem, p.22. Nesse contexto, é possível nos contrapor a Dreyfus e Rabinow no seguinte sentido: ao sustentarem que "a genealogia é um diagnóstico que se concentra nas relações de poder, saber e corpo na sociedade moderna", apesar de bem salientarem a presença da relação indissociável saber-poder relacionadas com o corpo, deixam escapar três questões que julgamos de amplitude mais vasta. DREYFUS, H e RABINOW, P. Michel Foucault: uma trajetória filosófica - para além do estruturalismo e da hermenêutica. Rio de Janeiro: Forense, 1995, p.117.) Primeiro, por atribuírem à genealogia um papel de diagnóstico quando já lhe atribuíram um papel metodológico, o que gera uma oscilação que enfraquece a ação tática da genealogia, como pensamos. Depois, por colocarem no corpo uma ênfase deslocada dos efeitos globais do poder e saber, quer dizer, o corpo, como entendemos, não é temática restrita à genealogia: o saber e o poder se relacionam, embora de modos distintos, na constituição do corpo numa incansável relações de forças que já estão presentes nos empreendimentos arqueológicos. Enfim, não podemos ignorar que o percurso histórico dos volumes II e III da História da Sexualidade está longe de se concentrar na sociedade moderna, o que indica que a genealogia transpassa os limites de uma "modernidade" no que concerne ao próprio corpo.
} 
A nosso ver, fica claro, a partir desse delineamento, que o corpo é acontecimento incontornável de toda inscrição histórica, o que põe em xeque, mais uma vez, a unidade substancial de qualquer Eu. O corpo pulveriza toda identidade por ser múltiplo e multiplicado, donde "a genealogia, como análise da proveniência, está portanto no ponto de articulação do corpo com a história. Ela deve mostrar o corpo inteiramente marcado de história e a história arruinando o corpo" ${ }^{140}$.

A admissão do entroncamento de distintas raízes, acidentes e dispersões heterogêneas, que marcam a proveniência, acentuarão, de maneira obtusa, o campo crítico de onde a genealogia se posiciona para se dirigir ao ponto de surgimento dos movimentos que marcam a história. Com o intuito de se distanciar cada vez mais da busca exaustiva de uma Ursprung, a genealogia somará ao campo da proveniência (Herkunft) o que pode ser considerado o princípio e a lei singular de uma aparição, o seu ponto de surgimento, que se situará numa Entstehung, quer dizer, numa emergência. Contudo isto não significa que seja possível encontrar qualquer explicação pelo termo final do acontecimento, do fato, do que se vê, enfim, do que emergiu. É preciso, antes de mais nada, termos em conta que não é possível enxergar na emergência fins acabados: "esses fins, aparentemente últimos”, diz-nos Foucault, "não são nada mais do que o atual episódio de uma série de submissões" "141. Decorre daí a suspeição de que o presente emana de uma origem, de uma continuidade sem interrupção, forçando uma destinação que procuraria a sua emergência desde o primeiro momento. Mas, como se trata de não ignorar a dispersão dos acontecimentos, fato já delineado desde a rarefação arqueológica, o que põe em evidência a constante problemática da descontinuidade, “a genealogia restabelece", por intermédio do viés da emergência, "os diversos sistemas de submissão: não a potência antecipadora de um sentido, mas o jogo casual (hasardeux) das dominações" ${ }^{142}$.

Posto desta forma, podemos compreender que "a emergência se produz sempre em um determinado estado das forças" (forces) ${ }^{143}$. Seu estado, contudo, não nos remete ao que existe primariamente, o dado mais original, a marca coerente assinalada na fixação de um signo qualquer; tal estado muda a sua representação pelo fato de ser acidente, quer dizer, livre de uma coerência fechada, logo pode ser visto de maneiras distintas. Assim, ao conceber a emergência em relação ao estado das forças, vemos Foucault destacar que "a análise da

\footnotetext{
${ }^{140}$ Ibidem, Id.

${ }^{141}$ Ibidem, p.23.

${ }^{142}$ Ibidem, Id.

${ }^{143}$ Ibidem, Id.
} 
Entstehung deve mostrar seu jogo, a maneira como elas lutam umas contra as outras, ou seu combate frente a circunstâncias adversas, ou ainda a tentativa que elas fazem - se dividindo para escapar da degenerescência e recobrar o vigor a partir de seu próprio enfraquecimento" 144 . Em outras palavras, somos incitados a perseguir o que se situa fora de um campo de condições constantes, mas que pode ser apreendido pelo entrecruzamento da entrada em cena de forças que, para utilizarmos uma metáfora, passam dos bastidores para o teatro, para a cena histórica cujo vigor de sua visibilidade menos fala da cena em si do que de sua condição. De seu lugar, como nos autoriza Foucault, "ninguém é, portanto, responsável por uma emergência; ninguém pode se autoglorificar por ela; ela sempre se produz no interstício" ${ }^{145}$, quer dizer, entre o que foi considerado falha, perdido, invisível, menor.

Se a emergência situa a genealogia na dimensão das forças, não podemos ignorar a relação que a força estabelece entre quem dominou e foi dominado. Deste modo, por exemplo, enquanto "a proveniência designa a qualidade de um instinto, seu grau de desfalecimento, e a marca que ele deixa em seu corpo, a emergência designa um lugar de afrontamento" ${ }^{146}$, sem dúvida, em decorrência do estado das forças. Podemos situar melhor tal questão da seguinte forma:

homens dominam outros homens e é assim que nasce a diferença dos valores; classes dominam classes e é assim que nasce a idéia de liberdade; homens se apoderam de coisas das quais eles têm necessidade para viver, eles lhes impõem uma duração que elas não têm, ou eles as assimilam pela força - e é o nascimento da lógica. Nem a relação de dominação é mais uma "relação", nem o lugar onde ela se exerce é um lugar. E é por isto precisamente que em cada momento da história a dominação se fixa em um ritual; ela impõe obrigações e direitos; ela constitui cuidadosamente procedimentos $^{147}$.

Nada mais claro do que esta colocação para nos fazer ver que a tarefa do pensamento foucaultiano se circunscreve aos múltiplos rituais dessa história de dominação, claro, dando sempre visibilidade às formas pelas quais os jogos e suas regras permitiram que determinadas forças se plasmassem naquilo que passamos a conhecer por histórico. De acordo com a nossa abordagem, conceber a história na perspectiva de um estado de forças é sustentar que, doravante, ela não pode se limitar a repetir a própria linguagem, já que interpretar a relação das forças é assinalar na direção da multiplicidade, sobretudo porque o intérprete não é o

\footnotetext{
${ }^{144}$ Ibidem, Id.

${ }^{145}$ Ibidem, Id.

${ }^{146}$ Ibidem, Id.

${ }^{147}$ Ibidem, Id.
} 
mesmo. Então, a história pensa a condição de pensar o presente sem plenitude e o eterno passado e vir-a-ser - sem unidade.

O que decorre deste quadro, pois? Desse ponto, a multiplicidade do conjunto da obra de Foucault, concebida sob a irradiação da problemática da história crítica do pensamento, deixa evidenciar os distintos atos de uma peça única: a história coloca em cena o jogo da interpretação de sua própria história. Vista sob a esfera das forças, a emergência será irrefutavelmente dinâmica e múltipla. Doravante, a história tem de falar sobre as diferentes emergências, no entanto sem negligenciar que as suas demarcações "não são figuras sucessivas de uma mesma significação; são efeitos de substituição, reposição e deslocamento, conquistas disfarçadas, inversões sistemáticas" ${ }^{\text {"148 }}$. Então, a história não pode mais dar-se à tarefa de colocar em foco uma significação única e oculta na verdade de uma origem e tomar tal fato por interpretação. Uma vez que a emergência levou em consideração a relação das forças, trazendo para o jogo histórico os procedimentos de dominação, interpretação passa a ser, nos termos do filósofo francês, "se apoderar por violência ou sub-repção de um sistema de regras que não tem em si significação essencial, e lhe impor uma direção, dobrá-lo a uma nova vontade, fazê-lo entrar em um outro jogo e submetê-lo a novas regras"149. Eis, em cena, um labor infinito ciente de sua limitação à medida que toma consciência de que não há mais do que interpretações, pois um horizonte se lhe apresenta cada vez mais distante: o da conclusão essencial de interpretação. Se não somos mais autorizados a buscar a conclusão do passado, também não o somos para encontrar a do futuro, nem a chave de uma saída revolucionária qualquer, donde "o devir da humanidade é uma série de interpretações"150.

$\mathrm{Na}$ verdade, ao relacionar a pesquisa de proveniência e de emergência, a genealogia passa a colocar em foco um determinado sentido histórico que critica a "forma histórica que reintroduz (e supõe sempre) o ponto de vista supra-histórico", quer dizer, opõe-se a

uma história que teria por função recolher em uma totalidade bem fechada sobre si mesma a diversidade, enfim reduzida, do tempo; uma história que nos permitiria nos reconhecermos em toda parte e dar a todos os deslocamentos passados a forma da reconciliação; uma história que lançaria sobre o que está atrás dela um olhar de fim de mundo [...] que supôs uma verdade eterna, uma alma que não morre, uma consciência sempre idêntica a si mesma ${ }^{151}$.

\footnotetext{
148 Ibidem, p.26.

${ }^{149}$ Ibidem, Id.

${ }^{150}$ Ibidem, Id.

${ }^{151}$ Ibidem, Id.
} 
Mas se a genealogia, de uma maneira bem diferente, não se apóia sobre nenhum absoluto, um outro sentido é possível de ser forjado, ao passo que, na proposta de Foucault,

ele [o sentido] deve ter apenas a acuidade de um olhar que distingue, reparte, dispersa, deixa operar as separações e as margens - uma espécie de olhar que dissocia e é capaz ele mesmo de se dissociar e apagar a unidade deste ser humano que supostamente o dirige soberanamente para o seu passado ${ }^{152}$.

Não sem propósito, a interpretação focaliza o vir-a-ser, já que fica evidente que o sentido histórico, de agora em diante, toma o que se tinha acreditado imortal no homem como aspecto a ser indiciado pela história. Em outras palavras, pela genealogia, os sentimentos mais desinteressantes possuem uma história; os instintos não atuaram de uma mesma maneira; o corpo não se circunscreve aos limites e às leis fisiológicas, como se escapassem à história; nenhuma constância é empalmada, bastante fixa "para compreender outros homens e se reconhecer neles"153. Ao contrário, a partir do momento em que Foucault situou a descontinuidade como marca indelével da história, procurou aprofundá-la na genealogia, identificando-a na busca de uma história "efetiva" - à luz de Nietzsche, Foucault diria wirkliche Historie. Com isso, é preciso nos atentar para a farta argumentação do filósofo:

tudo em que o homem se apóia para se voltar em direção à história e apreendê-la em sua totalidade, tudo o que permite retraçá-la como um paciente movimento contínuo: trata-se de destruir sistematicamente tudo isto. É preciso despedaçar o que permitia o jogo consolante dos reconhecimentos. Saber, mesmo na ordem histórica não significa "reencontrar" e sobretudo não significa "reencontrar-nos". A história será "efetiva" na medida em que ela reintroduzir o descontínuo em nosso próprio ser. Ela dividirá nossos sentimentos; dramatizará nossos instintos; multiplicará nosso corpo e o oporá a si mesmo. Ela não deixará nada abaixo de si que teria a tranqüilidade asseguradora da vida ou da natureza; ela não se deixará levar por nenhuma obstinação muda em direção a um fim milenar. Ela aprofundará aquilo sobre o que se gosta de fazê-la repousar e se obstinará contra sua pretensa continuidade. É que o saber não é feito para compreender, ele é feito para cortar ${ }^{154}$.

Por meio desse movimento argumentativo, tomamos parte no sentido necessário à capacidade de "destruição sistemática" advinda das operações que a história efetiva, estrategicamente, põe em marcha. Assim, assumimos que esse ímpeto inexorável faz ecoar a argumentação maior do filósofo desde a arqueologia, de onde toda tradição da história, continuidade, teleologia, racionalismo e encadeamento natural, para citar alguns exemplos, passam a ser suspeitados e superados. A razão disso se dá pelo fato de Foucault aprofundar,

\footnotetext{
152 Ibidem, Id.

${ }^{153}$ Ibidem, p. 27.

${ }^{154}$ Ibidem, p.26-27.
} 
em partes, o caráter estocástico da história, notadamente, ao associar a descontinuidade às forças que se encontram num jogo histórico qualquer, fato evidenciado pela genealogia, pois ela reconhece que "as forças que se encontram em jogo na história não obedecem nem a uma destinação, nem a uma mecânica, mas ao acaso da luta" ${ }^{155}$. Luta que não cessa de acontecer e de questionar o sentido da verdade e de seus jogos, melhor ainda, operação beligerante a favor da história que não repõe para nós, que vivemos referências e coordenadas originárias: signos presentes num mapa, que aliviariam o medo de se perder numa rota desconhecida. É por isso, com efeito, que, ao serem reconhecidas na história, as forças "não se manifestam como formas sucessivas de uma intenção primordial; como também não têm o aspecto de um resultado. Elas aparecem sempre na álea singular do acontecimento"156. Mas que não confundamos, aqui, a singularidade do acontecimento com a sua monotonia. Ao contrário, a primeira expressa a capacidade que a genealogia traz de poder interverter a relação entre o próximo e o longínquo, no sentido de invadir a fidelidade causal dos acontecimentos e substituí-la pela fidelidade casual ${ }^{157}$. Outrossim, a singularidade não é o fato simples, irrisório, porém efetividade que faz circular um saber histórico perspectivo, pois "o mundo tal qual nós conhecemos não é essa figura simples onde todos os acontecimentos se apagaram para que se mostrem, pouco a pouco, as características essenciais, o sentido final, o valor primeiro e último" ${ }^{\prime 158}$. Mais do que isso, a singularidade permite ao pensamento um espanto à medida que põe em visibilidade o verdadeiro sentido histórico a reconhecer, para nos valermos de uma expressão de Foucault, "que nós vivemos sem referências ou sem coordenadas originárias, em miríades de acontecimentos perdidos" $" 159$.

Desde o instante em que Foucault trouxe à baila a sua crítica à origem, delineando com proveniência e emergência um sentido histórico efetivo, no mesmo passo, estava esboçando três conseqüências marcantes para a história crítica do pensamento, sob o prisma do que

\footnotetext{
${ }^{155}$ Ibidem, p. 28

156 Ibidem, Id.

${ }^{157} \mathrm{O}$ fato mais exemplar, nessa direção, que podemos indicar em Foucault, toca o tema do sujeito. Se tomarmos de modo bem simplista e arbitrário o fato de que a filosofia moderna se posiciona acerca da afirmação e representação do homem como sujeito, portanto de sua oposição ao objeto, mas também se fazendo objeto de conhecimento - no que vemos a partir do século XVII florescer -, Foucault, em seus últimos trabalhos, vai analisar um vasto período histórico entre os séculos $\mathrm{V}$ a.C até $\mathrm{V} \mathrm{d}$.C (contexto grego-romano) para sustentar que a emergência das idéias e valores acerca de uma subjetividade estão longe dos valores restritos ao pensamento moderno (acompanhamos a argumentação de Descombes em Le complément du sujet: enquête sur le fait d'agir de soi-même. Gallimard, 2004). Nessa mesma direção, julgamos que foi isso que Ferry e Renaut não entenderam ao afirmar que: "nos últimos trabalhos [de Foucault] manifestam uma falta de nitidez deliberada ou não, no uso da noção de sujeito" (Opus cit. p.137). Talvez ainda tendo em mente uma tradição filosófica do sujeito que celebra a sua emancipação através do progresso da consciência ocidental, tais comentadores deixam de contemplar esta temática concernente, em Foucault, a uma outra perspectiva.

${ }^{158}$ Ibidem, p.29.

159 Ibidem, Id.
} 
pretende ser a análise genealógica, que agora ele leva a cabo. Mas é importante termos em mente que foi a partir desse conjunto de questões, ressalte-se, tomando a noção de genealogia empreendida por Nietzsche e utilizando-a de modo instrumental, que Foucault esquadrinha $o$ uso que a história pode, então, fazer da análise genealógica. Este visa um uso específico atinente à história a fim de libertar-se da história supra-histórica.

Sendo assim, em primeira mão, a análise genealógica instaura o que Foucault designou de uso paródico e burlesco da história. Longe da ingênua intenção de atingir o seu fundo, de encontrar o reconhecimento primordial que pudesse justificar um tema assentado numa "história-reminiscência", apoiando-nos em uma expressão do filósofo, o uso paródico e burlesco da história reconhece todo o jogo de máscaras que não instila o fato real, ao contrário, aponta para a irrealidade que não assegura nenhum reconhecimento duradouro simplesmente porque a história é apenas um disfarce. Então, devido a isso, vem à tona a relação que a genealogia umbilicalmente tem com a discursividade, jogos de verdade e a própria vontade de verdade ínsita à própria história, porém, desde o momento cujas questões foram contempladas pela rejeição da quimera da origem, não se perdeu mais de vista o fato de que "a vontade de verdade, essa que se impõe a nós há bastante tempo, é tal que a verdade que

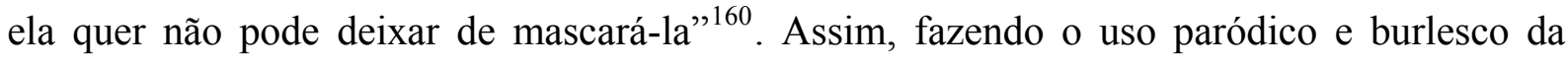
realidade, Foucault "em vez de identificar nossa pálida individualidade às identidades marcadamente reais do passado", tratará "de nos irrealizar em várias identidades reaparecidas" 161 , justamente porque o genealogista compreende que as identidades disponíveis na história, todas elas, não passaram de uma grande mascarada. Por essa razão, a análise genealógica questiona a nossa vontade de verdade; não toma o discurso pela versão que intenta instituir, mas restitui a ele seu caráter de acontecimento; ademais, suspende a soberania do significante, pois já tem em consideração que "a genealogia é a história como um carnaval organizado"162.

O outro uso da história será denominado por Foucault de uso dissociativo e destruidor da identidade. À guisa da genealogia, subtende-se que a história como carnaval organizado possui as suas séries diferentes - cada bloco carrega a sua alegoria, a sua identidade distinta -; mais ainda, suas "evoluções" não são as mesmas, metáfora para a história serial que fez sucumbir a continuidade. Dessa maneira, a "identidade, bastante fraca contudo, que nós tentamos assegurar e reunir sob uma máscara, é apenas uma paródia: o plural a habita”,

\footnotetext{
${ }^{160}$ FOUCAULT, M. A ordem do discurso, p.20.

${ }^{161}$ FOUCAULT, M. Nietzsche, a genealogia e história. In. Microfísica do poder, p.32.

${ }^{162}$ Ibidem, p.34.
} 
evidentemente pelo fato de se partir da relação de forças existentes na Herkunft e Entstehung, além disso, "almas inumeráveis nela disputam; os sistemas se entrecruzam e se dominam uns aos outros" ${ }^{163}$. Sob esse prisma, torna-se cada vez mais aguda e vertiginosa a dimensão descontínua e dissipada da história, pois, mediante a dissociação, “a história não descobrirá uma identidade esquecida, sempre pronta a renascer, mas um sistema complexo de elementos múltiplos, distintos, e que nenhum poder de síntese domina" ${ }^{\natural 64}$. Posto assim, fica claro, cercando-nos dos termos do filósofo francês, que

\footnotetext{
a história, genealogicamente dirigida, não tem por fim reencontrar as raízes de nossa identidade, mas ao contrário, se obstinar em dissipá-la; ela não pretende demarcar o território único de onde nós viemos, essa primeira pátria à qual os metafísicos prometem que nós retornaremos; ela pretende fazer aparecer todas as descontinuidades que nos atravessam ${ }^{165}$.
}

Sabendo que a descontinuidade golpeia e invalida as identidades, sobretudo a do instante e a do sujeito, a genealogia, então, quer clarificar as múltiplas heterogeneidades que, sob a máscara de qualquer Eu, proíbem a engrenagem perpétua de toda identidade, pois nada ocupa para sempre o mesmo lugar, muito menos o lugar que se imagina.

Desse ponto, objeto e sujeito são problematizados a partir da perspectiva que consente com a variação da manifestação e do alcance heteromorfo da história. Em outros termos, o terceiro uso da história catalisa o sacrifício do sujeito do conhecimento, pois irá se valer da dimensão interpretativa que a genealogia inaugurou para destruir a verdade depositada no fundo identitário e original, opondo-se, assim, à história do conhecimento, é dizer, à unidade de representação que, doravante, quer se referindo ao objeto quer ao sujeito, será cindido, não mais soberano, mas dependente - posto em relação a toda constituição, sem origem absoluta, todavia aberto às certas funções que não cessam de se modificar. Quem propôs a interpretação? Indagação fundamental que cumpre a função do autor do enunciado, mas também a função do autor da história, sem perder de vista que "a função autor é a característica do modo de existência, de circulação e de funcionamento de certos discursos no interior da sociedade"166. Eis o resultado mais violento da interpretação que fraturou a consciência histórica, ademais, também pelo fato de desviar do querer-saber o fundamento de toda análise histórica. Então, se a interpretação

\footnotetext{
${ }^{163}$ Ibidem, Id.

${ }^{164}$ Ibidem, Id.

${ }^{165}$ Ibidem, p.34-35.

${ }^{166}$ FOUCAULT, M. Qu'est-ce qu'un auteur? Dits et Écrits I, Nº 69, 1969, p.789.
} 
se interroga e se de uma maneira mais geral interroga toda consciência científica em sua história, ela descobre, então as formas e transformações da vontade de saber que é instinto, paixão, obstinação inquisidora, refinamento cruel, maldade; ela descobre a violência das opiniões preconcebidas: contra a felicidade ignorante, contra as ilusões vigorosas através das quais a humanidade se protege, opiniões preconcebidas com relação a tudo aquilo que há de perigoso na pesquisa e de inquietante na descoberta ${ }^{167}$.

Encontramos, nessa perspectiva, o afastamento de toda verdade que se queira universal. Além disso, a longínqua aventura de confiabilidade do homem em sua razão a fim de controlar a natureza histórica da verdade, que deve estar presente nos arranjos de sua segurança, notadamente das previsibilidades necessárias que prolongam a sua própria finitude, ficará abalada, pois, a partir do sacrifício dessa estabilidade, a história não cansará de "multiplicar os riscos", de fazer "nascer os perigos", abatendo as "proteções ilusórias". Destarte, a genealogia tem o primor em "desfazer a unidade do sujeito; liberando nele tudo o que se obstina a dissociá-lo e a destruí-1o"168.

Após esse percurso, em certo sentido, não seria exagero de nossa parte afirmar que, atraída pela força questionadora acerca da idéia de um método imutável, sistemático e universalmente aplicado ao pensamento, montante da arqueologia; a genealogia, tática operacional que ativa os saberes libertos da sujeição, pode ser concebida como a jusante da arqueologia a fim de ativar ao pensamento histórico a transformação do seu campo de experiência. Não se trataria, nesse nível, de querer somar ou subtrair arqueologia e genealogia, mas tomá-las a partir de suas características peculiares, com efeito, focalizadas na tentativa de passar em revista não somente os discursos aquinhoados nos mais diferentes cenários - "nós vivemos cercados de cenários" ${ }^{\text {169 }}$, diria a nós Foucault -, como também fazer circular a provisorieidade de toda análise fincada na positividade do que somos, pois essa nossa condição de ser histórico se limita pelo ilimitado da história. Objeto e sujeito são erodidos num questionamento recíproco, pois estão ligados. Cercados pela dimensão da história crítica do pensamento, uma das mais vertiginosas originalidades de Foucault, vemos ocorrer um movimento que desenraiza e fragmenta o solo de suas certezas, pois as suas relações são costuradas em práticas históricas e, nesse ponto, "a História mostra que tudo o que é pensado o será ainda por um pensamento que ainda não veio à luz" ${ }^{170}$. De repente, damo-nos conta de que avançamos mancando.

\footnotetext{
${ }^{167}$ FOUCAULT, M. Nietzsche, a genealogia e história. In. Microfísica do poder, p.35.

168 Ibidem, p.36.

169 Ibidem, p.32.

${ }^{170}$ FOUCAULT, M. As palavras e as coisas, p.515.
} 


\section{AS RELAÇÕES DE FORÇAS NOS PROCESSOS HISTÓRICOS DE CONSTITUIÇÃO DAS SUBJETIVIDADES}

Visível e invisível, dois mundos no Homem se entrelaçam.

T. S. Eliot

Coros de "A Rocha"

\subsection{O campo das situações estratégicas para o entendimento das subjetividades}

Na década de 1970, Foucault assume e firma uma formulação teórica crucial, mas nem sempre percebida como fundamental. Sua importância e status, contudo, somam-se para compor uma chave imprescindível de elucidação deste domínio brumoso e problemático que são as relações de forças nos processos históricos de constituição das subjetividades, e a formulação um pouco enigmática acerca do sujeito. Trata-se da questão do nominalismo.

A afirmação de que, "sem dúvida, devemos ser nominalistas"1 emerge do contexto cuja preocupação central são "as relações de força desequilibradas, heterogêneas, instáveis, tensas" ${ }^{\prime 2}$. E isto não é surpreendente, pois, de fato, a questão não apenas revelará o quanto é ingênuo buscar na expressão de um nome um conceito contínuo que não seja a formulação constante de um problema, portanto, passível de transitoriedade, como também selará mais a preocupação com os efeitos advindos de qualquer forma terminal que possa ser analisada. Loucura, sexualidade, vida, poder, governo e sujeito são apenas formas terminais, cujos efeitos de forças são incansáveis nas ações de exercício de modificação constante de qualquer um desses nomes dados "a uma situação estratégica complexa numa sociedade determinada" Mas em que, de fato, esta questão poderia ser elucidativa para a temática presente?

O nominalismo de Foucault engendra em sua particularidade mais do que um ceticismo sistemático em relação a qualquer universal antropológico. Leva às últimas conseqüências o caráter constitutivo de qualquer objeto relacionado, imprescindivelmente, com certos dispositivos históricos. Quando na lição de 8 de fevereiro de 1978, do curso

\footnotetext{
${ }^{1}$ FOUCAULT, M. História da sexualidade I: a vontade de saber, p.89.

${ }^{2}$ Ibidem, Id.

${ }^{3}$ Ibidem, Id.
} 
Sécurité, Territoire, Population, vemos se descortinar a sentença de que "a loucura não existe", testemunhamos a exemplificação contundente não de sua negação, mas de sua afirmação por processos diversos que não pretendem imobilizar em torno da loucura uma identidade contínua, mas permitir a concepção de sua modificação por inúmeros fatores de ação sob a dimensão mutatis mutandis dos dispositivos históricos ${ }^{4}$. Isto representa o tratamento vertiginoso dispensado aos objetos em consonância aos campos de verdade que cada um deles ocupa e, nessa trama, concomitantemente, porém modificando as suas próprias manifestações. Assim, cada recorte tomado como foco de análise está permeado por processos diversos segundo grandes estratégias de saber e poder que extrapolam o seu sentido meramente material: várias relações estão em jogo, em um momento dado, resguardadas pela singularidade de um nome que não é frio, passivo, quieto nem estático; mas é estratégico.

É sob esta dimensão, então, que nada existe em si mesmo, fora de uma relação, cuja existência primeira se fundamentaria em um ponto central e não em pontos de dispersão. $\mathrm{O}$ nome resguarda, no máximo, a estabilidade fugaz, que em breve já encontrará sua modificação no plano da inteligibilidade. Na dimensão da história, essa inteligibilidade "residiria, talvez, em algo que se poderia chamar de a constituição ou a composição dos efeitos" $"$. Efeitos, por sua vez, consignados às certas funções que deflagram, ocupam e dissipam outros efeitos. A sexualidade é exemplo ímpar, irradiando para as outras temáticas a mesma dimensão. Diz-nos Foucault:

a sexualidade é nome que se pode dar a um dispositivo histórico: não à realidade subterrânea que se apreende com dificuldade, mas à grande rede da superfície em que a estimulação dos corpos, a intensificação dos prazeres, a incitação ao discurso, a formação dos conhecimentos, o reforço dos controles e das resistências, encadeiam-se uns aos outros, segundo algumas grandes estratégias de saber e de poder. ${ }^{6}$

São as diferentes formas de encadeamento e o fluxo de suas manifestações, como destacamos, as tais composições dos efeitos, no espaço de certas perspectivas estratégicas de saber e poder, o conjunto da forja que trabalhará caracterizando, ao mesmo tempo que distingue as séries de práticas distintas cujos nomes comportam efeitos singulares, pois a inevitabilidade de cada prática suscita a diferença crucial que cada uma delas ocupará na realidade. Deste ponto de vista, podemos acrescentar que o nominalismo representa o nome dado a um dispositivo histórico fecundo, desde o gérmen, por forças que se conjugam na

\footnotetext{
${ }^{4}$ Antes disto, Foucault também chegou a afirmar: "o poder, isto não existe" (Cf. Le jeu de Michel Foucault. Dits et Écrits III, No 206, 1977, p.302), o que comprova que a loucura é só mais um exemplo nominalista.

${ }^{5}$ FOUCAULT, M. Sécurité, Territoire, Population, p.244.

${ }^{6}$ FOUCAULT, M. História da sexualidade I: a vontade de saber, p.100. Grifos nossos.
} 
ordem do événementiel. ${ }^{7} \mathrm{Na}$ verdade, nos deparamos com as conseqüências finais da tese lançada desde As palavras e as coisas: habitamos, cada um, num espaço de relação de situações estratégicas, onde seus efeitos não são sentidos e vividos da mesma maneira. "A loucura, a doença, a delinqüência, a sexualidade", como também o poder, não se trata das mesmas coisas, pois há um regime de verdade tão múltiplo e dissímil que coordena e interfere em qualquer série de práticas que, apesar de "não existir, torna-se alguma coisa, alguma coisa que, contudo, continua a não existir", ainda que forme "um dispositivo de saber-poder que marca efetivamente no real o que não existe e o submete legitimamente à divisão do verdadeiro e do falso" ${ }^{\prime}$. Julgamos encontrar aqui um indicador relevante para se pensar quais são os regimes deste jogo de forças, cuja divisão entre o verdadeiro e falso é apenas uma incipiente forma, que perpassa os campos da existência individual e social, fazendo-nos recepcionar, crer e agir à guisa de um universo de legitimações que, desde a ciência, passando pela política, valores morais e instâncias de governamentalidades, define e retroalimenta o que pode ser verdadeiro e falso a partir de então.

Mas, se Foucault permanece implacavelmente nominalista ${ }^{9}$, é porque enxerga nesse ponto a incontornável presença de conjugações de forças na história cujos termos, do mais simples aspecto no âmbito do acontecimento insignificante até a ruptura maior de uma virada

\footnotetext{
${ }^{7}$ Com isto, seguimos na direção contrária àquela que pensou Wahl. Embora comentando acertadamente que "nem transcendente nem transcendental", mas que "a função do discurso é de verter-se em uma prática"; engana-se, contudo, ao sustentar a prática estritamente sob a perspectiva de um pragmatismo, tentando, assim, debilitar o nominalismo de Foucault: "a topografia da escolha 'filosófica' não seria", argumenta Wahl, "do lado do nominalismo, mas do pragmatismo". (Cf. WAHL, F. Hors ou dans la philosophie? In. Michel Foucault philosophe. Rencontre internationale. Paris, 9, 10, 11 janvier 1988, p.89). Para nós, a própria perspectiva histórica baseada no événement não nos permite enxergar a prática fora de uma relação igualmente transitória e descontínua, que não se fixa na estabilidade de um nome. Nesta perspectiva, reconhecemos mais a interpretação de Veyne, a quem, aliás, Foucault abertamente presta homenagem e reconhece a influência quanto ao nominalismo. Ele nos diz: 'Em vez de acreditar que existe uma coisa chamada 'os governados' relativamente à qual os governos se comportam, consideremos que os 'governantes' podem ser tratados seguindo práticas tão diferentes, de acordo com as épocas, que os ditos governados não têm senão o nome em comum". A possibilidade de um nome é, "em certa época, o conjunto das práticas que engendra, sobre tal ponto material, um rosto histórico singular, em que acreditamos reconhecer o que chamamos, com uma palavra vaga, ciência histórica ou, ainda religião; mas, em outra época, será um rosto particular muito diferente que se formará no mesmo ponto, e, inversamente, sobre um novo ponto, se formará um rosto vagamente semelhante ao precedente. Não existe 'loucura através dos tempos', religião ou medicina através dos tempos"” (VEYNE, P. Como se escreve a história e Foucault revoluciona a história. Brasília: Editora UNB, 4.ed., 1998, p.243 e 268, respectivamente. Grifos nossos.) Ainda neste propósito, Rajchman compreendeu muito bem o ponto crucial que exerce o nominalismo, pois bem identificou que Foucault "usa a história para dissipar a espécie de rotina, a autoconfiança instituída que as pessoas alimentam a respeito da realidade de entidades tais como as desordens mentais, de que temem estar sofrendo, ou as necessidades sexuais internas que acreditam ter que descarregar. Ao questionarem essa realidade, as histórias de Foucault são nominalistas". (RAJCHMAN, J. Foucault: a liberdade da filosofia. Rio de Janeiro: Jorge Zahar, 1987, p.47-48).

${ }^{8}$ FOUCAULT, M. Naissance de la biopolitique, p.21-22. Aqui recortamos parte da argumentação que Foucault retoma quando, no curso do ano precedente, Sécurité, Territoire, Population (1977-1978) havia lançado a questão "a loucura não existe", como já foi indicado acima.

${ }^{9}$ Devemos esta expressão a DAVIDSON, A I. Régime de pouvoir et régimes de vérité. In. Michel Foucault. Philosophie anthologie. Paris: Gallimard, 2004, p.390.
} 
epistemológica, circunscrevem-se na figura transacional de uma realidade transitória. Embora a formulação seja um pouco obscura, trata-se de tornar absolutamente indiscernível o inconteste rigor da postura descontínua acerca das temáticas foucaultianas, em que, então, temos que "a realidade de transação" é aquela imersa "justamente no jogo e nas relações de poder e naquilo que incessantemente lhe escapa, de tudo isto que nascem as figuras transacionais e transitórias que, mesmo não tendo existido a todo o tempo, não são menos reais". ${ }^{10}$ Tais figuras são assim, pois participam de uma multiplicação causal segundo os processos diversos de sua constituição. A realidade, então, é transitória à medida que também é dependente de um polimorfismo crescente de forças; por isso mesmo, é transacional, ou seja, depende dos modos pelos quais as forças conseguem transigir, isto é, negociar formas e efeitos para, num momento dado, fazer surgir o que se singularizará, para novamente ser transigido e assim sucessivamente. Portanto o nominalismo indica não apenas o nível geral de como a realidade, os conceitos, as idéias e os acontecimentos são da ordem da fratura, como também o são da ordem da experiência, a devorar a própria experiência em constantes transações de forças: o nominalismo arrefece o que desde sempre está instaurado no pensamento de Foucault - o registro da constituição histórica de tudo.

Não nos pareceu possível passar ao largo desta questão pelo motivo de pensarmos ser ela um dos caminhos mais seguros e relevantes para colocarmos a problemática da subjetividade justamente em sua constituição histórica. Por quê? Devido à inevitabilidade de enfrentarmos a questão, tendo antes de esclarecer o deslindamento da concepção de sujeito, lançamos bases para antever $a b$ ovo os limites e os ganhos acerca de um termo cuja forma exprime uma "ficção extorquida" 11 , certamente, mas que, nem por isto, deixará de ter as suas implicâncias referentes às forças que carrega. É preciso ver, então, como o sujeito emerge e apresenta-se, como resultado incompleto, constituindo-se, alojado entre relações de força e história, codificando e codificado em certos campos de situações estratégicas, cujas deflagrações fazem-no subsistir, ruir-se, transformar-se, para novamente subsistir e assim sucessivamente.

O fato de termos insistido em trabalhar os contínuos e difíceis desvios operados por Foucault acerca de seu entendimento e tratamento dispensados à história e de como esses

\footnotetext{
${ }^{10}$ FOUCAULT, M. Naissance de la biopolitique, p.301.

${ }^{11}$ Esta expressão, tomamos de empréstimo de Honneth que, embora não a escolha conscientemente pela via do nominalismo, como aqui fazemos, acaba nos fornecendo um sólido argumento nesta direção ao atestar que "Foucault se apóia, no plano teórico, em uma crítica principal do sujeito enquanto sujeito constitutivo do sentido a fim de mostrar que o indivíduo moderno nada é a não ser uma ficção extorquida" (HONNETH, A. Foucault et Adorno: deux formes d'une critique de la modernité. In. Critique. Paris: Minuit, Ago-Set. 1986, Tomo XLII, No 471-472, p.812).
} 
diferentes movimentos são esquadrinhados à luz das mutações metodológicas efetivadas, o alcance de suas conseqüências ganha maior sentido agora numa perspectiva cuja abordagem corporifica a tese que aqui sustentamos. Sim, há uma concepção de sujeito no pensamento de Foucault, construída num campo muito específico e decisivo em torno do qual se orientam as condições precípuas a evidenciar como cada um de nós, indivíduos históricos, chegou ao ponto em que se encontra; apesar disto, sob quais formas seria possível, se é realmente possível, transgredir e superar este ponto inevitável no qual nos encontramos, e a que preço e propósito? O giro insistente ao redor desta problemática consiste em "desembaraçando-se do sujeito constituinte, desembaraçar-se do próprio sujeito, quer dizer atingir uma análise que possa dar conta da constituição do sujeito na trama histórica [...] sem se referir a um sujeito, que seja transcendente em relação ao campo de acontecimentos ou que circula em sua identidade vazia ao longo da história"12. Mas com isso estaria Foucault defendendo um determinado tipo de identidade concernente ao sujeito? Isto é, se é imperativo evitar qualquer princípio de ordem constitutiva, quais implicâncias acarretariam esta menção à identidade que, embora não podendo ser vazia, faz a sua ligação com a história? De uma coisa sabemos, a identidade deste sujeito não é vazia. Então, há um preenchimento, um tipo de relação de conteúdo, talvez, cuja ordem deve ser o possível sentido para o próprio entendimento deste sujeito?

Nunca é demais acentuar que, no pensamento de Foucault, há muito os atributos de transparência e soberania, marcas incontestes da filosofia ocidental moderna que procurou afirmar o homem como sujeito, foram dissolvidas. Apesar de toda querela em torno desta questão, o sujeito na ambiência foucaultiana traz à tona uma ligação sináptica com a subjetividade, embora não no estatuto da equivalência sinonímica, mas da ordem direta e incontornável com as implicâncias dos processos históricos de subjetividade ${ }^{13}$. Esta decisiva

\footnotetext{
${ }^{12}$ FOUCAULT, M. Entretien avec Michel Foucault. Dits et Écrits III, No 192, 1977, p.147. É preciso notar bem a real dificuldade e a verdadeira originalidade que tal perspectiva traz em seu bojo. Do contrário, menos por máfé do que por desatenção, corre-se o risco de enveredar-se, como fizeram Ferry e Renaut, no julgamento de "uma falta de nitidez deliberada ou não no uso da noção de sujeito" (FERRY, L.; RENAUT, A.; O Nietzschianismo francês (Foucault). In. Pensamento 68: ensaio sobre o anti-humanismo contemporâneo. São Paulo: Ensaio, 1988, p.137). É mesmo impossível querer exigir uma nitidez transparente acerca de uma noção acarretada de "uma diversidade de posições", mais do que isto, concebida à altura de uma "descontinuidade do sujeito", fato atestado por Wahl com o qual concordamos perfeitamente. (WAHL, F. Hors ou dans la philosophie? In. Michel Foucault philosophe. Rencontre internationale. Paris, 9, 10, 11 janvier 1988, p.87).

${ }^{13}$ Quando mencionamos querela neste contexto, levamos em consideração a ampla discussão que Descombes elabora acerca do que ele mesmo designou de "Querela do sujeito", com o intuito de apontar as amplas dificuldades dessa discussão desde o ponto em que se procura sustentar se o sujeito é uma marca da filosofia moderna, notadamente a partir do século XVII, ou se, nos Antigos Gregos, o homem já denotava a posição de sujeito a partir dos exercícios voltados para o conhecimento de si. Enfim, não estamos interessados nas linhas de constituição, afastamentos e diferenças que a História da Filosofia poderia abarcar referente à discussão do
} 
relação porta marcos definíveis, a nosso ver, extraídos de uma localização deslocante, a fim de viabilizar níveis de problematização acerca dos efeitos das relações de forças existentes na própria acepção do sujeito. E o que isto quer dizer? Que não se trata de uma titularidade enunciativa fora das implicações condicionais de onde se fala ou enuncia, ou seja, das constrições inevitáveis forjadas num jogo de verdade no qual somente determinados tipos de sujeitos podem aparecer sob específicas formas, isto é, constituírem-se como sujeitos sob formas determinadas. Já conhecemos as referências indicativas de quanto os discursos estão implicados em amplos "sistemas de sujeição" que "garantem a distribuição dos sujeitos que falam nos diferentes tipos de discurso e a apropriação dos discursos por certas categorias de sujeitos" ${ }^{14}$. Se pensássemos o sujeito pela sua capacidade de afirmar o seu Ego, pela ilusão do que anuncia, veríamos o quanto ele escaparia de si mesmo pelo fato de o sujeito se fundir com a transitoriedade de uma função-sujeito dependente de sua própria movimentação transitória nas fendas de onde se encontra, coloca-se para falar, coloca-se para ser falado.

Muito além disto, entretanto, delineia-se um horizonte cujo aspecto amplia as possibilidades, ou até mesmo as generalizam, para a compreensão do sujeito que, curioso notar, desemboca-se em um interessante oxímoro. Aliás, podemos até sustentar que não deixa de ser uma componente sintética de chave de leitura do pensamento de Foucault. Entendemos que o sujeito carrega, desde sempre, a fratura das relações de forças fundamentais à sua constituição. De um lado, já desde as categorias de sujeição enunciativa, ele é experiência sujeitada. Quando múltiplas formas de dominação ocupam a totalidade do interior da sociedade, desde "formas regulares, permissões e interdições que regem regularmente nosso cotidiano" 15 , circunscritas pela inevitabilidade operacional das técnicas e tecnologias minuciosas e calculadas de sujeição a produzir regularidades, como será aduzido adiante, aprofunda-se o nível do procedimento de sujeição que pode ser encontrado "nesses processos contínuos e ininterruptos que sujeitam os corpos, dirigem os gestos, regem os comportamentos"16. Este sujeito é semelhante ao subiectus, a latente ressingularização daquilo que está embaixo, pois sofre a ação permanente de um cálculo de forças constantes, embora não sendo as mesmas, cujos efeitos são sentidos em sua individualização. A argumentação própria de Foucault não nos deixa nos enganarmos neste sentido: trata-se "do

sujeito, tomando diferentes pontos de vista e concepções. (DESCOMBES, V. Les compléments du sujet: enquête sur le fait d'agir sur soi-même. Paris: Gallimard, 2004, p.29).

${ }^{14}$ FOUCAULT, M. A ordem do discurso, p.44.

${ }^{15}$ FOUCAULT, M; CHOMSKY, N. De la nature humaine: justice contre pouvoir. In. Sur la nature humaine: compreendre le pouvoir. Interlude. (Org.) F. Elders. Bruxelles: Les Editions Aden, 2006, p.48-49. Há também uma versão deste texto em Dits et Écrits I, 1954-1975, № 132, 1974, p.1339-1380.

${ }^{16}$ FOUCAULT, M. Em defesa da sociedade, p.33. 
sujeito submetido ao outro pelo controle e a dependência", ou ainda, a "essa forma de poder que se exerce sobre a vida cotidiana imediata, que classifica os indivíduos em categorias, os designa por sua individualidade própria, os ata à sua identidade, lhes impõem uma lei de verdade que ele deve reconhecer em si e que os outros devem reconhecer nele" ${ }^{\prime 17}$. Neste sentido, busca-se pensar o sujeito como objeto historicamente constituído sobre a base de forças que lhe são exteriores, mas que, pelo fato de constituí-lo e, portanto, fazerem parte do que o sujeito vai se tornando, são passíveis de transformação.

Em decorrência disto, então, o outro lado se revela. O sujeito enquanto experiência sujeitada pode se abrir para uma relação de afrontamento ao que não quer mais pertencer para sempre, procurando, assim, contornar estrategicamente toda trama de objetividade à qual vem pertencendo. Ele seria capaz de tentar constituir-se a si mesmo como sujeito de sua própria existência. É sob esta ótica que Foucault enxerga um tipo de "sujeito ligado à sua própria identidade pela consciência ou a consciência de si", no limite, um sujeito de ação. Nos dois casos, contudo, "a palavra [sujeito] sugere uma forma de poder que subjuga ou sujeita"18, todavia uma pela objetividade do dehors e outra pela subjetividade do dedans. Mas, ao invocarmos as relações de forças, torna-se fundamental nos mantermos adstritos ao fato de que o "sujeito é uma forma, e esta forma não é sobretudo nem sempre idêntica a ela mesma", pois "há, sem dúvida, relações e interferências entre essas diferentes formas do sujeito, mas não se está na presença do mesmo tipo de sujeito"19. Portanto o sujeito liga-se a uma

\footnotetext{
${ }^{17}$ FOUCAULT, M. Le sujet et le pouvoir. Dits et Écrits IV, No 306, 1982, p. 227.

${ }^{18}$ Ibidem, Id. Interessante notar que nisto faz muito sentido a observação de Védrine, na obra Le Sujet éclaté, ao destacar que "a noção de sujeito, maltratada há um século, parece se manter" [...] "O sujeito subsiste sob a dupla forma da tomada de consciência e de um projeto de criação de si para si” (2000, p.177 e 187). E, apesar da possível contradição que muitos vêem na concepção que ora esquadrinhamos, gostaríamos de ter em mente, postando-nos ao lado de Revel, que é perfeitamente concebível entender que "todo trabalho de Foucault consistirá precisamente em arranjar o movimento de objetivação no qual os indivíduos são necessariamente submetidos - para ser reconhecidos como sujeitos - e os processos de subjetivação que, permitindo a estes mesmos sujeitos de se tornar atores de sua própria invenção, cesse de se apresentar como contraditório; ou mais precisamente que a sujeição a uma objetivação suportada, de um lado, e a resistência por meio de uma subjetivação percebida como ruptura desta objetivação, de outro, não sejam apenas identificadas como contraditórias mas, ao contrário, intimamente ligadas" (REVEL, J. Expériences de la pensée. Paris: Bordas, 2005, p.174). Mas isto, a nosso ver, só é possível de ser empreendido no contexto das relações de forças onde, é claro, o sujeito dá-se em incessantes zonas de forças que o produzem.

${ }^{19}$ FOUCAULT, M. L'éthique du souci de soi comme pratique de la liberté. Dits et Écrits IV, No 356, 1984, 719). A interpretação de Deleuze a este respeito é primorosa. Mesmo que ainda não tenhamos chegado a ponto de apresentar os campos definidores das relações de forças, ficam claros os seus sinas na presença da constituição do sujeito, ou melhor, nos possíveis compostos que as forças são capazes de resultar, mesmo transitoriamente, tipo de formas distintas: "O princípio geral de Foucault é: toda forma é composta de relações de forças. As forças no homem supõem somente lugares, pontos de aplicação, uma região da existência. Trata-se de saber com quais outras forças as forças no homem entram em relação, sobre tal ou tal formação histórica, e qual forma resulta deste composto de força. Já se pode prever que as forças no homem não entram necessariamente na composição de uma forma-Homem, mas podem se investir de outra maneira, numa outra composição, numa outra forma: mesmo em um curto período, o Homem nunca existe, e nem existirá. Para que a forma-Homem
} 
conotação bifronte, portador tanto da sujeição às forças históricas, a certo número de saberes sobre ele, às práticas de dominação e estratégias de governo sob as quais, de um modo ou de outro, todos somos tocados, quanto às possibilidades de constituir-se a si mesmo, de sujeitarse a si mesmo, relacionando-se com determinadas formas de forças que ele procura aplicar sobre si.

É preciso, por conseguinte, notar a inexistência do Sujeito e ressaltar as variantes pluralizadas e heteromorfas abrigadas numa mera forma terminal - sujeito -, cuja localização será sempre deslocante, pois dependente dos compostos de forças. Toda relação com estes compostos pode ser designada de subjetividade, daí o aspecto friável e coexistente, peculiaridade foucaultiana, da ligação sujeito-subjetividade. Ocorre, contudo, serem estas forças de ordem histórica, subsistentes às séries de acontecimentos e dispositivos que singularizarão a história em um jogo de probabilidades. À medida que se efetiva esta trama, e de dentro dela, é que haverá uma produção de subjetividade, um arsenal de condições determinantes para se constituir cada tipo de sujeito. Esta tomada, a nosso ver, traz uma implicação política inconfundível e inescapável. A fundamentação do ser do sujeito aqui é estritamente da ordem política: o ser é político, pois é produzido a partir de formas de constrição cuja existência depende de um jogo de verdade estabelecido na produção e circulação de enunciados, práticas, instituições, enfim, para se consolidarem, tiveram de chegar a uma visibilidade vitoriosa. Quer dizer, impondo-se sobre outras formas de verdade, criando uma divisão entre o verdadeiro e o falso, reforçando tanto um quanto outro, o que pode ser denominado de estratégia de veridicção, um tipo de verdade tornou-se pivotante, mas porque teve força para isto. Eis os termos de Foucault, ao que nos parece, neste sentido: "só pode haver certos tipos de sujeito de conhecimento, certas ordens de verdade, certos domínios de saber a partir de condições políticas que são o solo em que se forma o sujeito, os domínios de saber e as relações com a verdade" ${ }^{20}$.

Estas condições políticas se espraiam indefinidamente em qualquer tipo de situação e posição na qual o sujeito se encontra. No Ocidente, todos são e sempre serão objetos de um determinado saber, do nascimento à morte que, aliás, precisam ser reconhecidos por um tipo de certificado; todos estão sob o horizonte da funcionalidade e legitimação de certas verdades

apareça ou se desenhe, é preciso que as forças no homem entrem em relação com as forças do dehors muito especiais.” (DELEUZE, G. Foucault. Paris: Minuit, 1986, p.131).

${ }^{20}$ FOUCAULT, M. La vérité et les formes juridiques. Dits et Écrits I, 1954-1975, p.1421. Ainda a propósito do Ser político, não seria inoportuno lembrar que o próprio Deleuze, ao elaborar uma série de comentários acerca da obra de Foucault, por ocasião do lançamento de seu livro em homenagem ao filósofo, tenha dito: "nomear as potências impessoais, físicas e mentais que enfrentamos e combatemos quando tentamos atingir um objetivo, e só tomamos consciência do objetivo em meio ao combate. Neste sentido, o próprio Ser é político" (DELEUZE, G. Conversações. São Paulo: Editora 34, 1992, p.111). Grifos nossos. 
que, mesmo imperando para um só indivíduo, exercerão a sua precisão como/com força. Seja como for, pensar em sujeito é também pensar na particularidade das configurações de forças arregimentadas sob tal e tal perspectiva, capazes de tornar o sujeito célula, indivíduo; ou sujeito orgânico, classe, população, grupo. Quando se é possível falar, então, de um sujeito, é possível se falar de uma individuação de forças:

o indivíduo é o resultado de algo que lhe é anterior e que é este mecanismo, todos esses procedimentos que fixam o poder político sobre o corpo. É porque o corpo foi "subjetivado", quer dizer que a função-sujeito se fixou sobre ele, é porque ele foi psicologizado, porque ele foi normalizado; é por causa disso que algo como o indivíduo apareceu, a propósito do que se pode falar, se pode ter discurso, se pode tentar fundar ciências. ${ }^{21}$

Esta dimensão é muito importante, uma vez que revela que ninguém se torna o que se é fora de uma implicação de procedimentos que fixa e circula o poder político desde o corpo, unidade essencial de união de forças. Há em nós muito mais possibilidades de relações de forças do que a força nos faz crer.

A este respeito, então, devemos considerar a presença de uma arquitetônica política na fabricação do sujeito. Ela está diretamente associada, como veremos, às condições mais elementares de aplicação da tecnologia política do corpo. Melhor dizendo, o sujeito só o é ao passo de um exercício constante e atuante sobre seu corpo, que é produzido politicamente, sob a dimensão de um modo específico de sujeição. Isto é crucial, pois, quando Foucault disse que o que estudava era uma arquitetura, cremos tratar-se menos da questão das bases e mais dos territórios e de suas condições por onde foram e são traçados os edifícios que abrigam em seus dispositivos as estratégias de forças para a fabricação dos sujeitos, a começar pelo seu corpo. É preciso citar aqui um trecho bastante longo e conhecido, que perderia grande parte de sua relevância se fosse de todo resumido:

o corpo também está diretamente mergulhado num campo político; as relações de poder têm alcance imediato sobre ele; elas o investem, o marcam, o dirigem, o supliciam, sujeitam-no a trabalhos, obrigam-no a cerimônias, exigem-lhe sinais. Este investimento político do corpo está ligado, segundo relações complexas e recíprocas, à sua utilização econômica; é, numa boa proporção, como força de produção que o corpo é investido por relações de poder e de dominação; mas em compensação sua constituição como força de trabalho só é possível se ele está preso num sistema de sujeição [...] Essa sujeição não é obtida só pelos instrumentos da violência ou da ideologia; pode muito bem ser direta, física, usar a força contra a força, agir sobre elementos materiais sem no entanto ser violenta; pode ser calculada, organizada, tecnicamente pensada, pode ser sutil, não fazer uso de armas nem do terror, e no entanto continuar a ser de ordem física. ${ }^{22}$

\footnotetext{
${ }^{21}$ FOUCAULT, M. Le pouvoir psychiatrique, p.58.

${ }^{22}$ FOUCAULT, M. Vigiar e punir, p.28.
} 
Para nós, este excerto nos principia em três movimentos imprescindíveis a funcionar como chave de problematização e alcance da relação sujeito-subjetividade. Em primeiro lugar, mostra que o corpo é a matéria primeira e essencial que consubstancia no sujeito certas funções atreladas ao rigor de práticas fundamentadas num envergado sistema de ações e práticas agentes, ou seja, o corpo é o sinal primeiro do sujeito, o seu efeito revelador. Em seguida, revela que nenhuma ação de sujeição pacifica seus termos, mas cria produção. A sujeição é círculo vicioso intensificado; dá-se à medida que é produzida e produz ao passo que talha o sujeito: a presença e qualidade da força, apesar de variantes, são sempre inexoráveis. Finalmente, há uma dependência de uma gama heterogênea de instrumentos-agentes que, flexionados sobre a matéria corpo, produzem o efeito da constituição de uma experiência de função-sujeito que estorna ao próprio corpo novos efeitos e, portanto, um novo corpo. Podemos dizer que o sujeito se finaliza por determinados tipos de objetivo; donde a subjetividade se singularizará, como experiência, entre o intervalo da força a acionar um objetivo e o efeito real que esta ação produz sobre o próprio sujeito.

Desde este cenário, há sentido afirmar em Foucault o quanto "é perigoso considerar a identidade e a subjetividade como componentes profundos e naturais, que não seriam determinados por fatores políticos e sociais" ${ }^{23}$. Importa, contudo, indagar como essa identidade é produzida e consubstanciada no sujeito; que tipos de instrumentos podem ser utilizados neste incansável processo; pôr em evidência a própria força, mostrar seus mecanismos politizadores; os cálculos sociais determinantes - a pura exterioridade - na constituição do sujeito. Mas, se "os homens nunca deixaram de construir a si mesmos, isto é, deslocar continuamente sua subjetividade, de se constituir numa série infinita e múltipla de subjetividades diferentes e que jamais terão fim e nunca nos colocará face a face com algo que seria o homem" em um fundo sereno, homogêneo e unívoco, será preciso, de igual modo, nos lançarmos para uma frente de contra-força, de outras composições, a impelir o sujeito para além desta espécie de "sono dogmático" que é a sujeição. Sono que o próprio Foucault dele se despertou a partir de suas ênfases na constituição e experiência de si como plano de subjetividade embalado pelas relações de forças no governo de si e para si, digital inconfundível dos anos oitenta. Então as condições de um vir-a-ser distinto para o sujeito deverão ser pensadas e trabalhadas sob as regiões de embates a se interpor através, em face e por trás das forças. Afinal, complementa o filósofo francês, "os homens se engajam perpetuamente em um processo que, constituindo-os em objetos, ao mesmo tempo o desloca,

\footnotetext{
${ }^{23}$ FOUCAULT, M. Foucault étudie la raison d’État. Dits et Écrits IV, No 280,1980 , p.37.
} 
o deforma, o transforma e o transfigura como sujeito" ${ }^{24}$. Toda esta tarefa nos permitirá implodir, com o intuito de apreender os cacos e seus efeitos, o conjunto geral, para nós, das engrenagens que trabalham sob a falsa aparência de que o sujeito sugere permanência; ao contrário, sobre ele paira a frenética e contínua movimentação das situações estratégicas.

\subsection{As relações de forças na produção de subjetividades}

Como ocorre com a maioria das noções em Foucault, a de força não é esboçada de maneira clara e contínua. Sua disposição, contudo, pode ser encontrada em todos os níveis das relações entre indivíduos e grupos, em todas as formas de campos estratégicos de constituição de sujeitos, pois a força não é apofântica, é causa qualquer a modificar um estado de relações cujos efeitos não podem ocultar a sua presença; a força é tipo e forma de produção. Temos para nós que, para chegarmos ao seu entendimento, é imprescindível seguir as linhas que ativam o seu composto por intermédio de um núcleo de questões que, apesar de imbuídas de correlações de desequilíbrio, heterogeneidade, instabilidade e tensão, tramitam nos acontecimentos históricos como marca das perpétuas transformações operadas sob o seu registro. Outrossim, temos de nos voltar ao que a torna possível, fazendo-nos pensar que ela está dentro mesmo de um saber, isto é, é dependente de condições enunciativas. É ao longo, então, das operações realizadas pelas forças - questões de cálculo, estratégia e manobra apreendidas nas situações históricas problematizadas por Foucault, que ela ganha seu vigor, enquanto também é por onde poderemos circunscrevê-la com o intuito de melhor elucidar as condições produtivas de subjetividades.

Em si, a força não é cognoscível; também não é possível acessar a forma bruta de seu quantum. Em Vigiar e Punir, Foucault mencionava "o ronco surdo da batalha" que nos rodeia pelo fato de a todo instante um tipo de força se apresentar não em "um núcleo, mas em uma rede de elementos diversos - muros, espaços, instituições, regras, discursos" ${ }^{25}$, enfim, sob uma realidade mesclada a qual o pensamento não pode apreendê-la a um só golpe. Cada um desses elementos, por sua vez, diz respeito à série incontornável de embates necessários para que se firmasse a direção de um propósito e efeito. Mas por que há o muro, o espaço assim e assim, tal instituição e não outra, tais regras e discursos? Pois o que a força firmou, melhor ainda, efetivou, deveu-se aos arranjos e às interações que foram capazes de elaborar debaixo

\footnotetext{
${ }^{24}$ FOUCAULT, M. Entretien avec Michel Foucault. Dits et Écrits IV, No 281, 1980, p.75.

${ }^{25}$ FOUCAULT, M. Vigiar e punir, p.269 e 268, respectivamente.
} 
de certas condições, exigências, intenções e movimentos. Com isto, contudo, estaríamos afirmando uma dimensão de vontade própria? Não vontade, mas efeito próprio cuja dimensão é imanente à complexa emersão e extensão do poder. A força é o composto múltiplo, abrangente, polimorfo, reticular e inexorável do poder. A força está em campo; mas também define o campo, não qualquer tipo, porém, um semelhante ao de batalha. Assim, dotar a força de sentido é dotar também o poder de sentido. Fartamente é o que cremos dizer Foucault:

\begin{abstract}
parece-me que se deve compreender o poder, primeiro, como a multiplicidade de correlações de força imanentes ao domínio onde se exercem e constitutivas de sua organização; o jogo que, através de lutas e afrontamentos incessantes as transforma, reforça, inverte; os apoios que tais correlações de força encontram umas nas outras, formando cadeias ou sistemas ou ao contrário, as defasagens e contradições que as isolam entre si; enfim, as estratégias em que se originam e cujo esboço geral ou cristalização institucional toma corpo nos aparelhos estatais, na formulação da lei, nas hegemonias sociais ${ }^{26}$.
\end{abstract}

Temos aí um foco central que precisa ser olhado de mais perto. Para além da óbvia envergadura das relações de forças, a perspectiva do afrontamento é crucial, sobretudo porque retoma o canal da ligação política do sujeito com as forças, senão da própria característica política que a força é portadora à medida que se instala numa forma terminal momentânea, mas cuja deformação não demorará a ocorrer por conta de outras correlações de forças. Para tanto, o contexto do curso de 1976, denominado Em defesa da sociedade, avizinhando-se com as teses fundamentais de Vigiar e Punir, de 1975, torna-se chave importante nesta direção, pois lá será levada às últimas conseqüências a forma porosa e ubíqua das forças na presença dos vínculos humanos em que toda forma de relação se politiza.

Para tanto, o que aqui nos interessa especialmente encontra-se em uma formulação cuja expressão é capaz de escandalizar tanto os espíritos humanistas mais sensíveis quanto os mais pessimistas, como também pode constranger os adeptos das tentativas de se fazer vingar um tipo de paz perpétua na história, para não dizer no mundo. Diz, então, Foucault: “o poder é mesmo, em si, emprego e manifestação de uma relação de força [...] se deve analisá-lo antes e acima de tudo em termos de combate, de enfrentamento ou de guerra. O poder é guerra, é a guerra continuada por outros meios. A política é a guerra continuada por outros meios"27. Menos que definir política, enxergamos nesta passagem uma relação fundamental existente no emprego de forças com propósitos políticos, isto é, como ligação imprescindível e conseqüente que a aplicação da força traz a partir de um campo de ação que, sob determinadas condições, produz uma série de efeitos a se desdobrar sobre novas ações.

\footnotetext{
${ }^{26}$ FOUCAULT, M. História da sexualidade I: a vontade de saber, p.88-89.

${ }^{27}$ FOUCAULT, M. Em defesa da sociedade, p.22.
} 
Ora, a inversão operada por Foucault no aforismo de Clausewitz, como salta aos olhos, “a guerra não é mais que a continuação da política por outros meio",28, chegando, então, na hipótese avessa, em que a política é a guerra continuada por outros meios, impele-nos a uma compreensão que não pode se limitar ao episódio guerra propriamente dito. A guerra ganha um sentido "menor", como talvez diria Deleuze. Melhor ainda dizendo, microfísico, pois é o registro mais agudo a colocar a olho nu a implicância das relações de forças a perpassar o todo social e como essas forças são, visíveis e invisivelmente negociadas, circuladas, efetivadas numa amplitude que escapa dos tratados políticos, mas que sublinham todas as relações nas quais há menos mando e obediência direta que estruturas a chancelar e pulverizar as ordens; em que situarão os que podem mandar e os que podem obedecer; os que podem criar a lei e os que podem segui-la; os que podem punir e os que podem ser punidos. "O poder político, nessa hipótese, teria como função reinserir perpetuamente essa relação de força, mediante uma espécie de guerra silenciosa e de reinseri-la nas instituições, nas desigualdades econômicas, na linguagem, até nos corpos de uns e de outros" ${ }^{, 29}$. A política, com tanto maior vigor, faz sobressair os movimentos inexoráveis a animar indivíduos e grupos nas tramas históricas, conferindo até mesmo sentido nas relações que têm com lugares, discursos, práticas, enfim, com todo um conjunto de forças expressivas desta politização geral da existência.

Gostaríamos de sublinhar que vemos, nesta operação realizada por Foucault, um importante passo, dentre outros, para balizar o seu afastamento do viés político da soberania, e por que não dizer profissionalizada, cujo sentido de guerra, por exemplo, focalizaria as dimensões do interesse de um Estado contra um outro. Ele nos coloca muito além disto. Não se trata, contudo, de pensar o Estado completamente fora do interesse de nosso autor, isto não é verdadeiro, como veremos na ligação da subjetividade com os aspectos da governamentalidade. Entrementes, para nós, a guerra representa a relação belicosa imanente à força e ao poder: "o fundamento da relação de poder é o enfrentamento belicoso das forças" Visto sob este ângulo, é preciso notar bem, concebemos, à força necessariamente, um campo de afrontamento como condição essencial de seus deslocamentos enquanto os de seus efeitos também. Isto significa que, se "as relações de poder são relações de força”, serão, concomitantemente, de "afrontamento, portanto, sempre reversíveis", pois "não há relações de

\footnotetext{
${ }^{28}$ Ibidem, p.22.

${ }^{29}$ Ibidem, p. 23 .

${ }^{30}$ Ibidem, p.24.
} 
poder que sejam completamente triunfantes cuja dominação seja incontornável”. Donde, para Foucault, "estamos em toda parte em luta"31.

Esta concepção, entretanto, não nos soa velha demais à luz de Hobbes, cuja constatação da guerra de todos contra todos ocupava lugar proeminente no entendimento também das relações humanas e não apenas na condução do Estado? Não é o que nos parece quando nos posicionamos no fluxo da interpretação foucaultiana. O sentido com o qual nos deparamos acerca da luta em toda parte tem por objetivo causar sérias rachaduras na permanência da ação do poder e em seu próprio status, tendo em vista a sua ligação com forças cuja latência é da ordem incansável das modificações. Três implicações decorrem disto. Primeiro, é preciso notar que há uma estratégia em Hobbes cuja enunciação acaba acentuando, de acordo com a interpretação de Foucault, "o discurso do contrato e da soberania, ou seja, o discurso do Estado", donde, sob esta ótica, “o inimigo - ou melhor, o discurso inimigo ao qual se dirige Hobbes - é aquele que se ouvia nas lutas civis que fissuravam o Estado" 32 . Assim, há uma tentativa de se regulamentar o poder em que uma soberania pudesse assumir a vontade e personalidade de todos. Esta regulamentação, seu "jogo discursivo, certa estratégia teórica e política"33, eliminaria e tornaria impossível qualquer tipo de vis-à-vis estratégico no sentido de um embate real de forças. Tendo em vista a centralização de forças em um soberano, simbolizando as "representações calculadas", o estado de forças em Hobbes "não é em absoluto um estado natural e brutal, no qual as forças viriam se enfrentar diretamente: há representações, manifestações, sinais, expressões enfáticas, astuciosas, mentirosas; há engodos, vontades que são disfarçadas em seu contrário, inquietudes que são camufladas em certezas" 34 , porque se busca pacificar, função essencial do contrato, para não permitir a reivindicação constante daqueles que fazem e estão na trama dos jogos de forças. Foucault busca, de fato, as estratégias de lutas.

Então, em segundo lugar, o objetivo das forças não é fazer a guerra parar, estabilizarem-se até se pacificar um Estado, num estado, evidentemente sob o equilíbrio constante e prolongado das forças, num tipo de equação simplificada numa igualdade. Ao contrário, aliás, é ampliar a sua capacidade para que haja múltiplas sortes de enfrentamentos e afrontamentos que não podem ser negados desde a microporosidade dos acontecimentos. Hobbes forjou muito bem meios de afastar os inimigos da terminal de forças contidas no Estado. Foucault quer criar meios para ampliar as ações dos "inimigos", já que, sob as

\footnotetext{
${ }^{31}$ FOUCAULT, M. Pouvoir et savoir. Dits et Écrits III, No 216, 1977, p.407.

${ }^{32}$ FOUCAULT, M. Em defesa da sociedade, p.114.

${ }^{33}$ Ibidem, p.112-113.

${ }^{34}$ Ibidem, p.105-106.
} 
relações de força, temos consciência da frente de "batalha que perpassa a sociedade inteira, contínua e permanentemente, e é essa frente de batalha que coloca cada um de nós num campo ou no outro". Ao levarmos isto em conta, fica, então, patente que "não há sujeito neutro. Somos forçosamente adversários de alguém"35. Sendo assim, não haveria como conceber uma vontade soberana sem se pensar na anulação das atividades de forças. Por isto mesmo, o sonhado "fim que conduz à paz perpétua" de Kant, levando em conta "a totalidade da sociedade civil", também não pode ser concebido sem levarmos em consideração a minoração do campo de força. Minorada, aí sim, a força pode ser pacificada e, logo, estabilizada.

Finalmente, neste contexto, a latência universal das forças marcará a onipresença do poder em toda e qualquer relação, "não porque tenha o privilégio de agrupar tudo sob sua invencível unidade, mas porque se produz a cada instante, em todos os pontos, ou melhor, em toda relação entre um ponto e outro. O poder está em toda parte; não porque englobe tudo e sim porque provém de todos os lugares”. E, sendo assim, não há como deixarmos de pensar, então, que "onde há poder há resistências" 36 , pois os choques no curso de seu fluxo são

\footnotetext{
${ }^{35}$ Ibidem, p.59. Julgamos ser esta perspectiva que Zarka deixou escapar. Ao interpretar toda esta conjuntura de Foucault, toma o partido da crítica por julgar que este estaria sustentando um princípio político fomentador da "continuação da guerra por outros meios" quando, à luz de Zarka, melhor é "fazer a guerra parar" para que "a paz civil seja outra coisa que uma guerra silenciosa e contínua". Ocorre, contudo, que Zarka se coloca ao lado de um conceito jurídico de poder, como ele mesmo afirma, com a "função inversa de nos permitir pensar e crer que a guerra pode cessar" (Cf. ZARKA, Y. C. Figures du pouvoir: études de philosophie politique de Machiavel à Foucault. Paris: PUF, 2001, p.156). Todavia Foucault está do lado de uma concepção não jurídica de poder, cujos mecanismos polimorfos distendem, inevitavelmente, em horizonte e profundidade, as implicâncias inerentes ao poder e, dentre elas, estão as relações de forças. É claro que Foucault não promove a guerra; mas entende a vida num aspecto beligerante, já que a verdade no ocidente, como já veremos, é preponderância vencedora de uma ordem prático-discursiva, cuja vitimização não pode deixar de ser considerada. Contrariamente a Zarka, devemos insistir, não há como negar o aspecto beligerante das forças na história simplesmente, e daí fruto do viés nietzschiano de Foucault e não do hobbesianismo de Zarka, é preciso levar em conta que "a lei nasce das batalhas reais, das vitórias, dos massacres, das conquistas que têm sua data e seus heróis de horror; a lei nasce das cidades incendiadas, das terras devastadas; ela nasce com os famosos inocentes que agonizam no dia que está amanhecendo. A lei não é pacificação, pois, sob a lei, a guerra continua a fazer estragos no interior de todos os mecanismos de poder, mesmo os mais regulares. A guerra é que é o motor das instituições e da ordem: a paz, na menor de suas engrenagens, faz surdamente a guerra" (FOUCAULT, M. Em defesa da sociedade, p.59). Opor-se, questionar, mesmo que incipientemente, qualquer lei, já é circunscrever-se no âmbito de uma resistência. É disto, cremos nós, que se trata a aforismática expressão de que "a política é a continuação da guerra por outros meios", trata-se de uma política événementiel, sob a mesma equação da concepção de história e suas implicâncias. Eis, mais uma vez, o sentido de afirmarmos que o ser é político.

${ }^{36}$ FOUCAULT, M. História da sexualidade I: a vontade de saber, p. 89 e 92 respectivamente. Ewald situa com muita lucidez este aspecto de resistência desde a produção do corpo. Lembra-nos que "as táticas de dominação e sujeitamento não visam tanto a tornar os corpos passivos, mas torná-los ativos, capazes de um certo tipo de produção. Submeter, portanto, não para reduzi-los, mas para produzir e tornar produtivos". Por isto mesmo, "toda produção de corpo é produção de poder para o corpo. O que coloca para o poder um problema fundamental: produzir corpos, os submeter, é, ao mesmo tempo, dotá-los de poder. De onde a possibilidade permanente de retorno e de desvio do poder, a necessidade da batalha perpétua, o princípio da gestão das ilegalidades e das resistências" (EWALD, F. Anatomie et corps politiques. In. Critique. Paris: Minuit, Dez. 1975, Tomo XXXI, No 343, p.1257-1258). Eis aí uma importante chave a nos antever a dimensão móvel da
} 
inevitáveis. O plural aqui é valioso, pois amplia a contundência das forças em todos os âmbitos cabíveis ou não de ocorrência, quer dizer, situa imperativamente no nível da relação a força. Em tal caso, é relevante pensar o aspecto inerente das resistências às ações políticas, porque comprova ainda mais a perspectiva belicosa proposta por Foucault. Assim, as resistências serão sempre "possíveis, necessárias, improváveis, espontâneas, selvagens, solitárias, planejadas, arrastadas, violentas, irreconciliáveis, prontas ao compromisso, interessadas ou fadadas ao sacrifício" ${ }^{37}$, mas estarão sempre imbricadas com a força.

Tanto mais convincente se torna, por isto, a perspectiva de que a política é a continuação da guerra por outros meios. Nisto, guerra não será acontecimento bruto da batalha; mas fluxo perpétuo, cuja composição abrange os cacos menores dos "episódios, fragmentações, deslocamentos da própria guerra" em múltiplas batalhas, cuja generosidade da presença da força é incansável. Em outros termos, a guerra torna-se inteligibilidade da constituição do campo histórico-político dos sujeitos históricos, porque não somente permite ao pensamento analisar e decifrar as forças envolvidas nesta trama, conquanto produzir chaves importantes da compreensão deste jogo, mas autoriza-nos a enxergar os lugares que os sujeitos vêm a ocupar em posições estratégicas decisivas, podendo ser, assim, um modificador nas relações de forças. Não é à toa que Foucault concebe "as relações de força e o jogo de poder como a própria substância da história" ${ }^{38}$. Então duas conseqüências de longo alcance se depreendem daí. De um lado, "se há história, se há acontecimentos, se ocorre alguma coisa cuja memória se pode e se precisa guardar, é precisamente na medida em que atuam entre os homens relações de poder, relações de força e certo jogo de poder" ${ }^{\text {39 }}$. Em virtude disto, a necessidade do entendimento dos sujeitos históricos não prescinde da própria força inerente à história. Estamos, por um lado, em uma espécie de nó, uma dependência incontornável das forças na história e, reciprocamente, da história nas forças. Por outro, "por mais longe que vá, o saber histórico só encontra o indefinido da guerra, isto é, as forças com suas relações e enfrentamentos, e os acontecimentos nos quais se decidem, de uma maneira sempre provisória, as relações de força: a história nunca pode decifrar senão uma guerra que ela própria faz ou que passa por ela" ${ }^{40}$.

A afirmação de toda esta perspectiva serve-nos para lançarmos uma tese fundamental: as relações de forças não podem ser restabelecidas a partir do nada; outrossim, é de onde e

subjetividade. A própria mecânica de produção de sujeição fornece engrenagens de contra-sujeição, espécie de linhas de fuga, que ainda mais dão sentido às operações beligerantes da força.

${ }^{37}$ Ibidem, p.91.

${ }^{38}$ Em defesa da sociedade, p.202.

${ }^{39}$ Ibidem, Id.

${ }^{40}$ Ibidem, p.206. 
como são estabelecidas que as relações se darão. Parece-nos que, assim, Foucault nos faz experimentar também o seu mais pesado dos pesos: pois só se pode restabelecer a força "se existir algo como um movimento cíclico da história, se existir, em todo caso, algo que permita

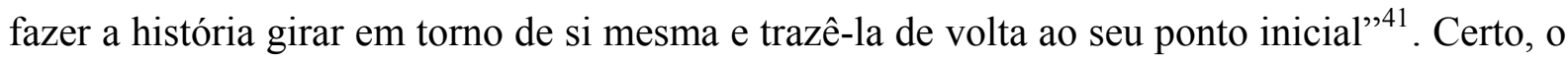
ponto inicial será sempre o dos embates, da beligerância, da guerra, das forças e seus efeitos. Mas o que não é o nada que pode restabelecê-la, fazê-la girar?

Entrementes, antes de avançarmos, não nos parece possível deixar passar em silêncio uma problemática que se processa, a nosso ver, no interior do esquadrinhamento geral de todo o percurso elaborado até este ponto. Ora, se é inegável a estreita aproximação, e por que não dizer entrelaçamento irrevogável, dos enfrentamentos e resistências com as relações de forças, não seria, deste modo, uma grave aporia defender a interpretação da constituição dos sujeitos históricos a partir dos cenários da sujeição? Quer dizer, como o sujeito pode ser constituído no vai-e-vem das contundentes ações de sujeição se inerente a esta possibilidade estão as forças belicosas descontinuando as ações do poder? E mais, se o sujeito pode se colocar na perspectiva de enfrentamento, como poderá ser sujeitado? É preciso uma grande lucidez, aliada a uma visão de conjunto, para não cairmos numa simplificação ligeira e deficitária de sentido. Para tanto, vale a pena apontar que, mesmo para as formas de sujeição mais vis, não são descartados os níveis de enfrentamentos ardilosos, improvisados, subterrâneos, micropotentes, rasteiros, até mesmo invisíveis, cuja aparição só pode ser apreendida pela ordem do acontecimento minúsculo. O fato de, nestas relações, prevalecerem as forças que se dispositivaram, por intermédio de operadores de dominação, não significa obter garantia de sua prevalência constante, do contrário, os tipos e efeitos determinados de poder poderiam ser eternos, mas não os são. Como a incidência é sempre da força, mesmo variando a sua intensidade, constância e pontos de aplicação, ela sempre parte do que "tem de factual, efetivo" 42 , isto é, dos elementos sobre os quais ela incide. Então, a sujeição, fruto da ação da força sobre determinados elementos, quanto mais intensa for, expressará maior intensidade; e para isso terá necessidade de constranger cada vez mais os espaços de mobilidade do sujeitado, a fim de concentrar a ação de seus domínios. É por isto, como cremos, que será necessário a Foucault mostrar as técnicas e tecnologias implicadas nos dispositivos responsáveis por canalizar a força, quer dizer, evidenciar quais são os instrumentos técnicos e cálculos que permitem garantir certas dominações e sujeições. E, ao fazer isto, deixará claro o quanto a força está sujeita aos desequilíbrios e rearranjos. Entre um desequilíbrio e outro;

\footnotetext{
${ }^{41}$ Ibidem, p. 230.

${ }^{42}$ Ibidem, p. 51.
} 
entre um rearranjo e outro, o sujeito irá se movimentando, contrapondo-se às margens constritoras, galgando espaço, enfim, armando as suas guerras, constituindo-se.

Em que pese este viés, não podemos, entretanto, nos esquecer: a força que se restabelece, forja-se em seus pontos de apoio, irá se efetivar nos variados canais de irradiação antes mesmo de se restabelecer novamente como força modificada e refazer o seu ciclo sob novas dimensões de efetividade. E, para tanto, ela conta com o quê? Em nosso juízo, com quatro grandes elementos englobantes capazes de precipitar, em série, seus novos rearranjos, de mantê-la sempre viva e atualizada e que, além disto, irão nos permitir entender porque a força é poder. Trata-se da verdade - jamais apreendida de uma só vez em Foucault, sobretudo porque, no âmbito da genealogia, relaciona-se com uma história política da verdade ${ }^{43}-$, do sempre presente espectro da enunciação em sua forma de comunicação, das estratégias e dispositivos de poder e, last but not least, das artes de governar tanto indivíduos como grupos ou populações.

Com efeito, a força está recoberta pela pátina da verdade. É possível, ao que nos parece, considerar a sua relação direta com a constituição do sujeito nas modalidades distintas contempladas pelo pensamento foucaultiano. De um lado, a verdade que produz efeitos de separação, divisão e afastamento a partir dos saberes sustentados por ela, pelas normas engendradas por suas ações, enfim, aportadas nos discursos que respaldarão práticas como a psiquiatria, a medicina clínica ou corretiva, cujo foco é o tratamento de toda sorte de sujeito desviante, podendo ser designado louco, doente, delinqüente, pervertido, anormal. De outro lado, temos a verdade cunhada indelevelmente nas constituições dos discursos, cujo status científico, notadamente no âmbito das ciências humanas, produz uma gama de saberes abrangendo o homem que vive, trabalha e fala, ou seja, verdades cujas matrizes projetam e pavimentam os caminhos com os quais o sujeito é entendido e concebido nos limites de sua várias finitudes: existencial, a vida; material, o trabalho; e de saber, o conhecimento. As

\footnotetext{
${ }^{43}$ Ainda mais uma vez, indicamos o quanto não é sem motivo Gros conceber a verdade como a questão central na obra de Foucault. Para Gros, a verdade é pensada como "produção, ritual, processos reguladores, ou ainda crise, guerra, relação de forças, vitória", um tipo de "geografia precisa", com a qual a verdade "se revela apenas em certos lugares e em certos quadros. Ela não pode ser pronunciada ou proferida senão por sujeitos qualificados. Ela depende de rituais corretamente executados, de dispositivos determinados, de circunstâncias e de momentos precisos. Ela supõe um jogo de forças móveis. Em suma, ela deve ser refletida como acontecimento produzido (événement produit) mais que como natureza descoberta (nature découverte)". Visto assim, de fato, a verdade perpassa da História da loucura até $O$ cuidado de si na trajetória foucaultiana. Mas, para nós, mais nos interessa notar a verdade em sua real efetivação e cremos, em todo este jogo, ser o sujeito o elemento terminal de maior concentração da geografia da verdade, ou como o próprio Gros enfatiza, da história política da verdade. É aqui que nos distanciamos um pouco deste notável comentador, embora, a partir dele, possamos nos posicionar no sentido de que é impossível abordar a verdade, dada a sua extensa presença na obra, em um lance só. (Cf. GROS, F. Michel Foucault, une philosophe de la vérité. In. Michel Foucault: philosophie anthologie. Paris: Gallimard/Folio, 2004. p.18-19).
} 
verdades produzidas pelas ciências que tocam a vida, o trabalho e o saber são as mesmas que interferirão, produzindo efeitos diferentes, na vida, nas condições de trabalho e no saber sobre e do homem. Estas duas frentes, no que defendemos, dizem respeito às forças que acionam os processos de sujeitamentos históricos, pura exterioridade que objetifica o homem como massa bruta para moldá-lo sob tais condições. Mas há a ligação da verdade também com a constituição do sujeito como objeto para ele mesmo. Ali, ele pode moldar-se a si mesmo de acordo com uma teleologia transitória, portanto subjetiva, que diz respeito apenas a si próprio. Neste quadro, a verdade é força constitutiva de um sujeito cujas experiências de força não advêm de um dehors, mas de um si para si. Eis neste cenário certa ordem lógica recoberta pelas obras História da loucura, O nascimento da clínica, Vigiar e Punir e A vontade de saber, numa via; em outra, As palavras e as coisas; e, finalmente, $O$ uso dos prazeres e $O$ cuidado de si, volumes derradeiros da História da sexualidade. Seja como for, encontraremos nesta conjuntura sempre a presença das relações de forças a se exercerem sobre uma multiplicidade em movimento, cuja trama final é a subjetividade do homem ocidental. Por quê?

Na prática, porque "não há exercício do poder sem uma certa economia dos discursos de verdade, que funcionam nesse poder, a partir e através dele". Assim, é patente a estreita ligação entre força e verdade, pois "numa sociedade como a nossa - mas, afinal de contas, em qualquer sociedade - múltiplas relações de poder perpassam, caracterizam, constituem o corpo social". Contudo, para isto ocorrer, as múltiplas relações de forças "não podem dissociar-se, nem estabelecer-se, nem funcionar sem uma produção, uma acumulação, uma circulação, um funcionamento do discurso verdadeiro". E, por isto mesmo, sempre "somos submetidos pelo poder à produção da verdade e só podemos exercer o poder mediante a produção da verdade"44. Tão logo seja assim, é inevitável que o tom do enfrentamento apareça mais uma vez, pois, ao mesmo tempo em que somos forçados a produzir verdade pelo poder, desde onde ele se institucionaliza, profissionaliza-se e busca recompensar a verdade, concomitantemente somos submetidos à verdade por uma série de forças pelas quais, sob diferentes aspectos, "somos julgados, classificados, obrigados a tarefas, destinados a uma

\footnotetext{
${ }^{44}$ Ibidem; acompanhamos a argumentação de Foucault às páginas 28-29. A interpretação de Ewald é impecável neste sentido e, para nós, acaba ressaltando a ligação da verdade com a força, em sua dimensão do poder, na perspectiva assinalada por nós de um fluxo que volta sobre si mesmo, contudo, à medida que se modifica. Diznos Ewald: "O que Foucault nos ensina? Que não é mais possível separar a verdade dos procedimentos de sua produção, e que esses procedimentos são enquanto procedimentos de saber procedimentos de poder. Que não há relação de verdade(s) independente das relações de poder que suportando-a, ao mesmo tempo, a reconduz e a reforça, que não há verdade sem política da verdade, que toda afirmação da verdade é indissociavelmente peça, arma ou instrumento nas relações de poder" (EWALD, F. Anatomie et corps politiques. In. Critique. Paris: Minuit, Dez. 1975, Tomo XXXI, No 343, p.1230).
} 
certa maneira de viver ou a uma certa maneira de morrer, em função de discursos verdadeiros" ${ }^{\prime 4}$. Entre produção e submissão, não podemos ignorar que a presença da verdade é sempre um discurso de perspectiva. Então e aí não podemos racionar a argumentação de Foucault,

\begin{abstract}
se a relação de força libera a verdade, a verdade, por sua vez, vai atuar, e em última análise só é procurada, na medida em que puder efetivamente se tornar uma arma na relação de força. Ou a verdade fornece a força, ou a verdade desequilibra, acentua as dissimetrias e finalmente faz a vitória pender mais para um lado do que para o outro: a verdade é um mais de força, assim como ela só se manifesta a partir de uma relação de força. $\mathrm{O}$ pertencer essencial da verdade à relação de força, à dissimetria, à descentralização, ao combate, à guerra, está inserido neste tipo de discurso, ${ }^{46}$
\end{abstract}

ou seja, no discurso da perspectiva.

Em nossa abordagem, a expressão de que a verdade é um mais de força faz sentido senão por sua ligação com a perspectiva a ser assumida pela própria verdade. Isto equivale a dizer, que, associada aos efeitos da força enquanto acontecimento, além de ela possuir uma geografia determinada, isto é, um espaço onde circula e age, lança mão de "mensageiros e operadores privilegiados e exclusivos" ${ }^{~}$, cujos vínculos com a verdade ocorre pelo fato de ser "o conjunto de processos que permitem a cada instante e a cada um pronunciar enunciados que serão considerados como verdadeiros" ${ }^{28}$. Mas isto jamais se efetiva sem o emprego dos mecanismos de força, quer dizer, é necessária a ação de saberes, práticas, suportes institucionais interligados pela complexidade dos dispositivos que produzem o campo de força real, ou seja, uma espécie de sítio onde vencedores e vencidos não estão do mesmo lado, ocupando os mesmos papéis, sofrendo os efeitos das mesmas forças, sendo entendidos sob a mesma perspectiva. E isto não é nada grandioso, pois é da ordem do acontecimento. Logo, a todo instante isto ocorre. A verdade-acontecimento (vérité-événement), como Foucault ressalta, encontra-se plenamente ritualizada, engendrada numa teia de forças que se aplica sobre todo o corpo social, está na base dos jogos de qualificação e desqualificação, é microplástica, pois seus pontos de aplicação são dispersivamente infinitos.

Por isto mesmo, será impossível conceber, por intermédio dos vínculos de comunicação por onde circulam a verdade, não importando qual, uma forma de entendimento pacífico e emancipador para a movimentação do pensamento e das ações humanas. Quer

\footnotetext{
${ }^{45}$ Ibidem, p.29.

${ }^{46}$ Ibidem, p.62.

${ }^{47}$ FOUCAULT, M. Le pouvoir psychiatrique, p.237

${ }^{48}$ FOUCAULT, M. Pouvoir et savoir. Dits et Écrits III, Nº 216, 1977, p.407.
} 
dizer, toda dependência e ligação com a comunicação é uma expressão de força, já que a própria força é que se comunica. Para haver o menor entendimento entre fluxos de signos e sentidos enunciativos, uma força teve de ser evocada ao menos para suprimir as barreiras que afastavam as discordâncias, os escolhos no ato da comunicação. Há uma semiótica da força na comunicação. Há uma beligerância na comunicação, pois supor que o papel de quem anuncia é equivalente ao de quem recebe o enunciado seria ignorar completamente o sentido idiossincrático de verdade construído no pensamento foucaultiano. Não sem motivo, o próprio Foucault argumentará o quão é inegável a presença das "relações de poder nos vínculos de comunicação que transmitem uma informação através de uma língua, um sistema de signo ou qualquer meio simbólico". E acrescenta a este propósito: "sem dúvida comunicar é sempre uma certa maneira de agir sobre o outro ou os outros"

A esta altura, todavia, a força carecerá do aparato de um conjunto de estratégias e táticas, para sermos mais exato, de manobras à guisa de sua consecução, pois o vínculo fundamental da verdade com as forças traz à tona a peculiaridade operacional de seu poder no poder. Este, por sua vez, "será garantido por uma multiplicidade, por uma dispersão, por um sistema de diferenças e hierarquias, porém mais ainda precisamente pelo que se poderia chamar uma disposição tática na qual os diferentes indivíduos ocupam uma localização

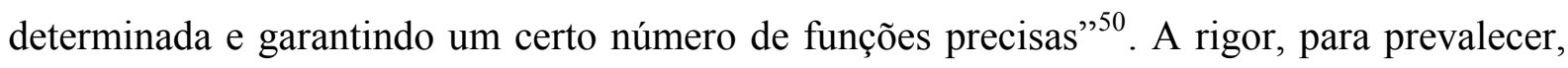
alguém, em algum lugar, imantado por certos discursos e apoiado por determinados canais, lutou pela verdade até que esta vencesse e se firmasse como força maior. Para tanto, o fundamento das manobras foi imprescindível na fixação deste jogo. Se correlacionarmos, na especificidade deste contexto, manobras com meios e instrumentos, como cremos ser possível, podemos deduzi-las a partir das formas de saber formal e informal constituídas no Ocidente - da ciência à superstição -, atuantes na canalização de certas perspectivas e concepções que bem delimitaram os campos de circulação e ocupação de uma série de

\footnotetext{
${ }^{49}$ FOUCAULT, M. Le sujet et le pouvoir. Dits et Écrits IV, № 306, 1982, p.233. Salta aos olhos o quanto esta perspectiva é totalmente contrapelo àquela propugnada por Habermas. Para este pensador, na competência lingüística, podemos encontrar a condição necessária e suficiente da racionalidade humana com o intuito de se chegar não somente a uma auto-reflexão individual vinculada a um tipo de educação social, digamos na direção de uma emancipação da consciência e ação humana. Mas tal competência seria irrevogável nas produções de relações inter-pares também emancipadas, donde o agir comunicacional seria imprescindível à guisa de uma "situação ideal de fala", cuja situação exclui deformações e imposições. Para Foucault, desde a mais incipiente forma de comunicação, há uma força que prepondera e engendra a comunicação. Além disto, pressupor um tipo de fala ideal seria inconcebível, a não ser se nos fizéssemos de cegos para todo tipo de ordem discursiva que está em jogo quando se pensa em "fala ideal". Seja como for, é no sentido da força que devemos entender este contexto aqui citado por nós, ou seja, que comunicar é agir, exercer uma força de sentido, representação, verdade; comunicar é poder. Não é à toa que, para Foucault, nenhuma interpretação, nenhuma hermenêutica será neutra.

${ }^{50}$ FOUCAULT, M. Le pouvoir psychiatrique, p.08
} 
indivíduos e grupos. Mas estariam também acampadas em toda prática destinada a otimizar o comportamento humano sob determinados fluxos de ordem, classificação, distinção, comparação, homogeneização e diferenciação a ponto de categorizar e quantificar não somente o plano subjetivo da personalidade individual - boa ou má - como a enquadrar as ações humanas sob certas expectativas. Ademais, não podemos passar ao largo das operações de extrema aniquilação da visibilidade existencial de grupos e traços inteiros de indivíduos, cujas vozes foram e são insistentemente silenciadas pelos constrangimentos das verdades impositivas da vida legal, e cujos testemunhos da ordem burocrática, da precarização material das condições humanas de subsistência e da rarefação de sua dignidade são meros exemplos de uma inebriante força. Não à toa, Foucault sublinha que, quando fala de estratégia, está levando "o termo a sério", uma vez que, "para que uma certa relação de força possa não somente se manter, mas se acentuar, se estabilizar, ganhar extensão, é necessário que haja uma manobra" 51 .

Se quisermos, entretanto, compreender bem o sentido e o alcance deste cenário, é primordial abandonarmos o plano geral da manobra e precisar melhor a sua especificidade vinculada ao exercício da força. É sensato, então, cotejar a eficácia da manobra como meio efetivo de força. Dentro do que sustentamos, parece-nos ser a problemática da arte de governar o vórtice mais potente da visibilidade das forças na constituição da subjetividade. Sem dúvida, pelo fato de ser o meio incontornável por onde todo tipo de verdade assumiu corpo e efeito, em que as formas de comunicação foram imprescindíveis e, não menos importante, por expressar e demonstrar os canais de manobras usados para se efetivar a força a ser finalizada na condução de indivíduos e grupos em todo corpo social. A arte de governar consistirá em "manipular, manter, distribuir, restabelecer relações de força", ou ainda, "se desdobrará num campo relacional de força" ${ }^{" 52}$. Isto equivale às formas de tecnologia política que, no curso do tratamento desta questão, abrange os tipos fundamentais de práticas incrustadas na longa história de condução e sujeição ocidental, desde a pastoral cristã até a biopolítica. Mas também, de outro lado, equivale às técnicas voltadas para a condução do sujeito a partir das forças que ele pode aplicar sobre si mesmo. Pouco importa, há uma trama persistente ou um tipo de cadeia cujas relações de forças são consubstanciadas nas práticas de governo. Nestas práticas, encontraremos os meios, destino final e catalítico da força; encontraremos ainda as estratégias na preparação de corpos, indivíduos, populações à guisa da eficiência da força, eficácia da verdade, da efetivação do poder. Assim, mesmo que existam

\footnotetext{
${ }^{51}$ FOUCAULT, M. Le jeu de Michel Foucault. Dits et Écrits III, No 206, 1977, p.309.

${ }^{52}$ FOUCAULT, M. Sécurité, territoire, population, p.319.
} 
linhas de forças que nunca se encontrem, contudo, em sua ramificação final, está a própria expressão terminal da força. Em cada forma, uma força; em cada força, uma forma de conduzir, governar, de ela se efetivar. "Devemos considerar que relações de poder/ governamentalidade/governo de si e dos outros/relações de si para consigo compõem uma cadeia, uma trama e que é em torno destas noções que se pode articular a questão da política e a questão da ética" ${ }^{93}$. Ora, sob este horizonte, o sujeito é condicionado às formas pelas quais a sua constituição foi e continua sendo armada desde as forças que agem sobre ele para governá-lo, extrair dele a sua própria força, incutir nele outras forças, situá-lo em certas demandas e finalidades.

Eis, então, ao longo do contexto deste movimento, o que consideramos os pontos vitais das relações de forças. Eles expressam um deslindamento condicionante aos próprios exercícios de poder, equivalente material e subsistente da força que, por não ser estável, a coloca no registro dos embates, das guerras, dos enfrentamentos. Outrossim, há, concomitantemente e na própria força, uma força motriz; o seu mecanismo consiste na interação dos componentes que a sustenta e, por mais paradoxal que possa parecer, também dela emanam, pois verdade, comunicação, manobras e arte de governar não somente criam e atualizam a força, como também dependem dela para se efetivarem. O mapeamento revela mesmo uma truncada trama a provar que a nossa história continua sendo a história das relações de forças. Mas aí, precisamente por isto, é que teremos condições de conceber a subjetividade como experiência política intercambiante, a fazer dos processos de sujeição um jogo para a sua dessujeição. Neste ínterim, entretanto, uma indagação vem à tona seguida de uma resposta, cujo entendimento nos lança para uma perspectiva a compreender:

não é, depois de tudo, um dos traços fundamentais de nossa sociedade que o destino toma a forma da relação de poder, da luta com ou contra ele? O ponto mais intenso das vidas, aquele onde se concentra sua energia, está bem aqui onde elas se chocam com o poder, com ele se debatem, tentam utilizar suas forças ou escapar de suas armadilhas. ${ }^{54}$

\footnotetext{
${ }^{53}$ FOUCAULT, M. A hermenêutica do sujeito, p.307.

${ }^{54}$ FOUCAULT, M. La vie des hommes infâmes. Dits et Écrits III, No 198, 1977, p.241. Grifo nosso.
} 


\subsection{Das técnicas às tecnologias políticas: o uso e aplicação das forças nos processos de sujeição.}

A diferença sensível entre a idéia de uso e aplicação das forças se faz notar não somente por intermédio de uma semiótica distinta que ocorre entre ambas, tanto mais, porém, por nos colocar perante umbrais separados, cujos caminhos, embora tocados por nódulos de contato, conduzem à ordem das condições ou causas, de um lado, e das recepções ou efeitos das forças, de outro. Aquelas se confundem com um aspecto geral e ubíquo das forças, pois se encontram em todos os tipos e níveis de relações não apenas humanas, mas nas ligações dos saberes, em seus vínculos institucionais, nas suas maneiras de alcançar circulação, contornos e difusão, enfim, entranhadas e indissociáveis do que já denominamos pontos vitais da força. $\mathrm{O}$ uso da força é amplo e recobre todo corpo social e os acontecimentos. Seu uso é político ao passo que com a política se imiscui, pois pressupõe os embates ocorridos, mesmo que subrepticiamente, a fim de consolidar um certo uso e não outro de força. Já suas aplicações, contudo, dão-se no âmbito de pontos particulares. $\mathrm{O}$ uso da força é engendrado com o intuito teleológico de atingir relevância a partir de uma aplicação contundente, do contrário perderia o seu vigor e iria se espraiar até não mais provocar efeito ou de efetivar-se, correndo o risco, assim, de não alcançar forma. Não significa, apesar disto, que a aplicação das forças não se generalize ou se restrinja em demasia. Ao contrário, são amplos e nada exíguos os pontos de suas aplicações. Todavia ocorrem por pontos: por exemplo, o saber é um uso geral da força, pois se vincula à verdade; como se canaliza a fim de ser aplicado, dependerá de sua finalidade última, portanto, bem delimitada. Enfim, poderíamos dizer que o uso das forças é global; e a aplicação serial, a depender de cada ponto.

Como ocorre com a própria força, as conjugações e combinações de uso e aplicação, pelo fato igual de serem históricos, são potencialmente inesgotáveis porque se renovam na dinâmica do curso dos acontecimentos, práticas, discursos, nos dispositivos e na própria esfera dos enfrentamentos consuetudinários aos da politização da existência. De nossa parte, assumiremos que tomar a ligação, sempre no registro de fluxo, do saber com o poder, perscrutando a inegável conseqüência com as técnicas e tecnologias políticas envolvidas nesta dimensão, tornar-se-á mais do que suficiente para aquilatarmos as conseqüências adstritas ao uso e aplicação das forças concernentes à constituição dos sujeitos e das subjetividades implicadas nestes processos. Nisto, no entanto, convém sublinhar a dependência indissociável 
desta problemática com os campos de sujeição que, a rigor, são os determinantes iniciais no delineamento do sujeito, justamente porque as cenas históricas serão démarches do uso e da aplicação de forças.

À guisa desta vertente adotada, é preciso nos reposicionar em face do saber. Nele, é possível encontrar pontos de sutura tão fortes a condicionar a estrutura do encaminhamento das forças, pois para Foucault, e isto não é nenhuma novidade, toda instância de saber funciona antes como instância de poder cuja engrenagem também funcionará sob dependência do saber. Então, é preciso buscar nele, já que o saber não deixará de envolver o poder, os pontos de aplicação pelos quais, vis-à-vis, "as relações de poder dão lugar a um saber possível, e o saber reconduz e reforça efeitos de poder" ${ }^{\text {"5 }}$.

A julgar pelas peculiaridades da história ocidental, o saber assume estratégias hiperbólicas em sua eficiência, chegando mesmo a regular todos os planos, encadeamentos e experiências das coisas, enquanto produção objetiva, e das relações e práticas humanas, enquanto produção subjetiva. Neste nível, o saber, a título esquemático, arma-se e apresentase na positividade da verdade científica, dos dispositivos e das ações, pois ele incita à verdade, a tudo que o poder acampa e às manifestações de conduta. No limite, faz-nos ver que toda produção histórica é regulada, pois tipos diferentes e determinados de saber estão aplicando as suas forças nesta produção.

Há, a isto consoante, uma relevante passagem de As palavras e as coisas que, a bem da verdade, introduz-nos de maneira muito esclarecedora no âmbito do saber como operador dos mecanismos da progressão da verdade, portanto em seus planos reguladores. Sem deixar de lado o vasto contexto com o qual Foucault situa como historicamente o sujeito pode tornar-se numa dada época objeto de conhecimento e, inversamente, como tal estatuto teve efeito sobre as teorias do sujeito enquanto ser que vive, fala e trabalha, podemos enxergar, por intermédio do exemplo das ciências humanas - o homem já como objeto dissolvido, porque dependente da relatividade de perspectivas com as quais é tomado por objeto -, o peso do saber como verdade reguladora. Melhor ainda, o peso do saber engendrado pelo poder inventivo, pois nenhum poder está ligado ao desconhecimento, "mas que, ao contrário, só pode funcionar graças à formação de um saber" ${ }^{\text {56 }}$. Eis a passagem:

as ciências humanas não tratam a vida, o trabalho e a linguagem do homem na maior transparência em que se podem dar, mas naquela camada de condutas, de comportamentos, de atitudes, de gestos já feitos, de frases já pronunciadas ou escritas,

\footnotetext{
${ }_{55}^{55}$ FOUCAULT, M. Vigiar e punir, p.31.

${ }^{56}$ FOUCAULT, M. Os anormais, p.64.
} 
em cujo interior eles foram dados antecipadamente, numa primeira vez, àqueles que agem, se conduzem, trocam, trabalham e falam. ${ }^{57}$

Os efeitos contidos nestes termos são tão evidentes quanto assustadores. A começar pelo aspecto englobante presente nas ciências humanas, menos, talvez, por marcar a sua pretensão de abordagem e entendimento do homem em suas fundamentais positividades, que a presença rarefeita de tipos diversos de saberes os quais não abrem mão de atuarem sobre o próprio homem sob formas reguladoras. Ocorre, contudo, que esta atuação se dá, notadamente, no registro das condutas, aliás, no âmbito das empiricidades mais essenciais. Neste caso, notemos a armadilha, um tipo de saber foi necessário como engrenagem antecipada para fazer mover as condutas. Donde então, podemos dizer, é possível encontrar desde o nível do saber em seu aspecto científico, ou melhor, em suas verdades científicas, até as expressões de forças reguladoras a agir constantemente nas coletâneas discursivas que caracterizarão esta ou aquela ciência; tanto esta mesma ordem científica redobrará em ação, já antecipada, pois teorizada, as formas práticas capazes de suscitar e formar o próprio tecido das experiências, quanto elas próprias. No limite, se somos forçados a falar em sujeito, encontraremos neste recorte a expressão de reposta mutabilidade a indicar que não há forma terminal acabada para ele, pois jamais deixará de ser alvo e reverberação das constantes aplicações do saber.

Em nosso juízo, entretanto, é preciso dilatá-lo para níveis mais corriqueiros e ordinários, para a porosidade mais extensiva das camadas de condutas, extrapolar a sua formalidade, ir além de sua eficiência reguladora. Mais do que isto, devemos chegar à órbita das "imensas possibilidades de discurso", "discursos da banalidade", como também das práticas com elas interligadas, a fim de não ignorarmos o uso e aplicação de "um certo saber do cotidiano, ao menos parte de sua origem, e com ele, uma grade de inteligibilidade que o Ocidente começou a colocar sobre nossos gestos, sobre nossas maneiras de ser e fazer", amalgamando desde o silêncio mais cálido "a mesquinharia tão vergonhosas de suas intenções" ${ }^{58}$. Que concebido desta forma, é inegável dizer, torna-se absolutamente impossível

\footnotetext{
${ }^{57}$ FOUCAULT, M. As palavras e as coisas, p.490.

${ }^{58}$ FOUCAULT, M. La vie des hommes infâmes. Dits et Écrits III, No 198,1977 , p.248-49 e 244. Ter em mente, a este propósito, a interpretação de Deleuze é não abrirmos mão de uma importante chave esclarecedora de análise do saber. Levando em conta que "o saber é um agenciamento prático, um dispositivo de enunciação" - e precisamente aqui já sabemos o que está implicado nesta noção - "e de visibilidade", então, podemos pôr em relevo que o saber, além de não ser a ciência, está orientado para toda e qualquer prática: “Apenas existem práticas, ou positividades, constitutivas do saber: práticas discursivas de enunciado, práticas não-discursivas de visibilidades". (Cf. DELEUZE, G. Foucault. Paris: Les Éditions de Minuit, 1986, p.58-59). Isto nos ajudará a buscar no saber os procedimentos estabelecidos por certas práticas, cujos exercícios e domínios chancelam
} 
e insensato intentar atingir o saber em seu fundo. Recoberto e entrecruzado com a trama do cotidiano, ele se perde e confunde-se com as infinitas histórias minúsculas a latejar em rotas desconhecidas. Mas sua pertinência não nos exime de um trabalho de escolha, cujo patamar ressalta, de todo modo, a amplitude de sua extensão inconfundível.

Então, se tomarmos a idéia de grade de inteligibilidade do saber a partir de suas intenções, emergirá um saber que "não toma corpo somente em textos teóricos ou nos instrumentos de experiência, mas em todo um conjunto de práticas e de instituições" $"$. Desta maneira, a sua condição de existência depende do que Foucault designou de "maquinaria", isto é, uma série de aparatos que "incita, suscita, produz; que faz agir e falar" ${ }^{60}$. Outrossim, há um processo de convergência do saber para si mesmo dentro desta maquinaria. Uma vez que ele é inseparável dos procedimentos que o estabelecem, como se isto não bastasse, também é capaz de criar novos procedimentos para efetivar suas aplicações. E será no âmbito dos processos de seu ordenamento, no alcance de sua homogeneização, condição sine qua non de toda regulamentação, acrescida de sua relação com a norma, que o saber atuará, desdobradamente, efetivando-se na direção da ordem das coisas, dos indivíduos e grupos humanos, enfim, conectando-se diretamente com as técnicas e tecnologias aplicadas à condução de tudo e todos, portanto, ao ponto fundamental da constituição dos sujeitos: o da disciplina.

$\mathrm{Na}$ realidade, o entendimento do saber nos permite antecipar a estrutura fundamental do poder disciplinar porque, aliás, ele não viria a ser se não fosse imanente à formação, à organização e à circulação de um saber. Para sermos mais precisos, de aparelhos de saber, quer dizer, de instrumentos efetivos a viabilizar a sua acumulação, "de técnicas de arquivação, conservação e registros, de métodos de investigação e pesquisa, de aparelhos de verificação", enfim, uma série amplamente contundente capaz de dar-lhe visibilidade e circulação desde estas intervenções ${ }^{61}$. Mas como o saber tornou-se disciplinado a ponto de desdobrar a disciplina a partir dele mesmo, isto é, de infligir e atuar disciplinando?

processos e procedimentos indissociáveis a certos agenciamentos de forças necessários para a formação do sujeito como função derivada destas práticas.

${ }^{59}$ FOUCAULT, M. Titres et travaux. Dits et Écrits I, No 71,1969, p.844.

${ }^{60}$ FOUCAULT, M. La vie des hommes infâmes. Dits et Écrits III, No 198, 1977, p.251.

${ }^{61}$ Aqui, além de seguirmos uma importante argumentação de Revel, julgamos interessante citar a interpretação dispensada por ela referente a tal ponto. Diz-nos: "ora, o poder não pode disciplinar os indivíduos sem produzir igualmente, a partir deles e sobre eles, um discurso de saber que os objetiva e antecipa toda experiência de subjetivação. A articulação poder/saber(es) será então dupla: 'poder de extrair dos indivíduos um saber, e de extrair um saber sobre estes indivíduos submetidos ao olhar e já controlados" (Cf. REVEL, J. Le vocabulaire de Foucault. Paris: Ellipses, 2002, p.56). Apesar da antecipação temática da disciplina concernente ao poder, cremos que a indicação é válida para ressaltar o envolvimento do saber na constituição de subjetivação, ou seja, 
Quando certos procedimentos intervieram a fim de organizar cada saber como disciplina, processou-se, nas dobras epistemológicas do século XVIII, do qual, concernente a isto, ainda somos herdeiros, um tipo de empreendimento que desenvolveu junto a todo saber novas regulamentações, com o propósito distributivo de equivalências e exclusões. Podemos dizer, as formulações de problemas específicos advindos de um saber que se especializa como ciência, como domínio geral regulador de diferentes saberes, irá se desdobrar "no século do disciplinamento dos saberes", imbricado com os problemas de "homogeneização, normalização, classificação e centralização". E, nisto, já pouco importa o tipo de objeto que a ciência focaliza, o seu enquadre, sobretudo se pensamos em referências ou quadro teórico de compreensão, raramente se desvirtua da "organização de cada saber como disciplina", do "escalonamento desses saberes" e de sua "intercomunicação, sua distribuição, sua hierarquização recíproca numa espécie de campo global ou de disciplina global a que chamam precisamente $a$ "ciência",62 . E não seria, assim, toda concepção possível de um objeto chamado sujeito passivo de um entendimento já tão disciplinado e arraigado nas regras que subsistem, explícita e implicitamente, em qualquer forma de saber? A dependência de sua enunciação, a priori, já indicaria isto. Porém isto não é tudo.

Para se processar o saber desta maneira, e aqui nos posicionamos de maneira genealógica, devemos ter em mente o eixo prática discursiva-enfrentamento de poder, por onde Foucault concebe "um imenso e múltiplo combate dos saberes uns contra os outros - dos saberes que se opõem entre si por sua morfologia própria, por seus detentores inimigos uns dos outros e por seus efeitos de poder intrínsecos"63. São no mínimo curiosos, embora as conseqüências sejam mais amplas, os resultados advindos desta forma de combate. Além dos enfrentamentos inevitáveis ao redor das disputas pela fixação dos discursos a fim de lograr a melhor chave de entendimento acerca das positividades e das coisas entrelaçadas a elas, a dependência inconteste do sujeito como fragmento conseqüente de um saber dispensado à sua visibilidade, concomitantemente, vai lhe negar a luminosidade extraviante quando não é encontrada em nenhum tipo de saber. As forças que agem sobre ele, deste ponto de vista, são as forças que permitirão, inicialmente, seus modos de ser. Incontornável destino sob o qual está sujeito e o qual pouco pode controlar.

Não é sem sentido, além de tudo isto, que Foucault localiza muito bem quatro procedimentos responsáveis por movimentar a fortuna desta morfologia do saber, cujas

de experiências pelas quais se obtém a constituição de um sujeito ou de uma subjetividade. O registro da norma, ao que nos parece, será o mais vertiginoso responsável por esta relação de constituição com o saber.

${ }^{62}$ FOUCAULT, M. Em defesa da sociedade; seguimos a argumentação do autor às páginas 216-218.

${ }^{63}$ Ibidem, p.214. 
conexões se articularão como delineadores de sua instância disciplinadora. Tangendo o primeiro procedimento, foi necessário que houvesse ou que se processasse um tipo de "eliminação, a desqualificação daquilo que se poderia chamar de pequenos saberes inúteis e irredutíveis", até mesmo, "economicamente dispendiosos" ${ }^{64}$. Em jogo, a emersão de linhas delimitadoras, portanto constritoras, responsáveis pela elaboração de uma espécie de seleção de saberes cuja homogeneização a se firmar estaria sempre em consonância com a estabilidade capaz de produzir, ou seja, de fornecer um estatuto reconhecido acerca do que se pretende. É assim que o louco não está mais preso à sua loucura, mas ao saber que produz a sua loucura; o preso não estará limitado às grades, mas ao Direito-Medicina legal que passa a atribuir e determinar a sua periculosidade; o doente, não mais fadado ao destino de sua doença, mas a toda sorte de manipulação de um saber que a clínica dispensa à sua doença; o sujeito, não mais detido em sua subjetividade inefável, mas nos limites dos saberes que estabeleceram todas as suas finitudes, enfim, os terrenos de suas ações sob alguns campos de experiências.

Em decorrência deste estatuto, veremos cristalizar o veio da normalização do saber. É dizer, "normalização dos saberes dispersos", permitindo "ajustá-los uns aos outros, fazê-los comunicar-se entre si, derrubar as barreiras do segredo e das delimitações geográficas e técnicas, em resumo, tornar intercambiáveis não só os saberes, mas também aqueles que os detêm" ${ }^{\prime 2}$. Expressão mais contundente da homogeneização, a normalização do saber eleva à última potência a capacidade de certas áreas do conhecimento científico penetrar ubiquamente em todos os níveis da existência, como vai se processar com "a medicalização geral do comportamento, das condutas, dos discursos, dos desejos, etc" ${ }^{\text {,66 }}$, não sem, contudo, valer-se do par siamês de toda disciplina, que é a vigilância desses mesmos comportamentos, condutas,

\footnotetext{
${ }^{64}$ Ibidem, p. 215.

${ }^{65}$ Ibidem, Id.

${ }^{66}$ Ibidem, p.46. A este propósito, se resgatarmos o contexto distante de nossa pesquisa e lembrarmos de como Foucault prezava os acontecimentos no prisma da atualidade, sobretudo concernente a uma visão crítica que não se conforma ao atual, mas que distende nele outras forças a fim de provocar novas experiências, ficaríamos ainda mais sensibilizados pelo diagnóstico preciso, elaborado por Ewald, referente à atualidade dos processos de medicalização nos quais estamos, independentemente de nossa vontade, envolvidos. Assim argumenta Ewald: "É preciso constatar que, hoje, a medicalização nunca foi tão forte e nem incitante. O que significa dizer que é no seio do exercício da medicina que hoje se encontra os lances de poder mais graves, mais fundamentais. E a medicina que desponta, a medicina genética, é uma medicina cujo anúncio é um império terrível. Temível porque é uma medicina que tem uma característica previsível: a partir de agora tem-se a possibilidade, ao menos potencialmente, de saber para cada um de nós, antes mesmo de nascermos, nossas predisposições às doenças que teremos" (EWALD, F. Foucault et l'actualité. In. Au risque de Foucault. Paris: Centre George Pompidou, 1997, p.210). Incrível notar, a julgar por estes termos, como se delineia uma possibilidade de sujeição in vitro não a um saber, mas ao mapeamento de experiência que não mais fugiriam ao nosso espanto, ao desconhecido experiência determinante, experiência apreendida a priori. A vida a ser concebida, de antemão, passa a ser selada à guisa de um saber controlador de suas reais potencialidades. Como veremos, o saber soube muito bem se permutar para expandir as suas aplicações até chegar ao ambicioso nível da biopolítica ou do biopoder. Melhor dizer, o saber soube se emancipar.
} 
discursos, desejos. A medicina, assim, é o exemplo mais acabado da normalização do saber em seu nível de aplicação. Por ele, os cenários da seleção, da qualificação, da utilização da vida e morte, do controle, do policiamento dos instintos e dos prazeres, enfim, dos enquadramentos quantitativos e qualitativos do que será prejudicial ou não, passarão a atuar como força de sujeição, como força difusora a exigir a correta justificativa a tudo que se faz. O sujeito, desta forma, também vai se constituindo como espectro deformado da ação deste saber normalizado.

Entretanto, ainda há mais. Com o intuito de canalizar eficazmente o aspecto normalizador do saber, ou seja, de optimizar a sua aplicação, uma classificação hierárquica será acionada. Doravante, como argumenta Foucault, é permitido, de certo modo, encaixar os múltiplos saberes "uns nos outros, desde os mais específicos e mais materiais, que serão ao mesmo tempo os saberes subordinados, até as formas mais gerais, até os saberes mais formais, que serão a um só tempo as formas envolventes e diretrizes do saber" ${ }^{\text {"67 }}$. Não apenas de onde se fala, como e por que se fala evidenciará a rede hierárquica na qual todos estamos implicados. Além disto, é claro, o que se é permitido fazer, sob a chancela de um saber que difunde as suas regras homogêneas nos espaços acolhedores e que significam, dando vigor, a sua expressão, irá se aplicar em todos os níveis de condutas, hierarquizando, assim, tanto o agente quanto a ação. Mas para esta possibilidade não correr o risco de perder a força de seus efeitos numa eventual falta de referência ou de diretriz, ao mesmo tempo que hierárquica, uma outra operação irá se processar com o intuito de permitir o "controle desses saberes". Falamos da centralização. Deste modo, ela "assegura as seleções e permite transmitir a um só tempo de baixo para cima os conteúdos desses saberes, e de cima para baixo as direções de conjunto e as organizações gerais que se quer fazer prevalecer" ${ }^{\prime 68}$. Mas algo, nisto tudo, não está claro: quem ou o que é o responsável por todas estas operações realizadas a fim de disciplinar o saber?

A notar pelos termos postos na explicação da centralização do saber, sobretudo por sua relação com as organizações gerais que o fazem prevalecer, não se trata de buscar a nascente determinante destas disposições; a origem transparente. Mesmo que as relações de controle impostas pelo Estado a partir do século XVIII sejam fundamentais, como o próprio Foucault argumenta, somos da opinião de que, sob o manto do dispositivo, da implicação permanente entre saber-poder e das relações de força, estas operações são como processos de racionalização do saber. São as interações que contam para a sua eficácia. Impossível não

\footnotetext{
${ }^{67}$ Ibidem, p.215-216

${ }^{68}$ Ibidem, p. 216
} 
dizer, assim, que "os níveis, cortes, estratos, ao mesmo tempo quantitativos e qualitativos, entre os diferentes saberes" não se tocariam numa forma de "saberes múltiplos, independentes, heterogêneos e secretos, e não no progresso constante do dia sobre a noite"69. Que haja uma certa astúcia do saber aí, parece-nos evidente, pois, no fundo, mesmo o excluído pelo jogo da homogeneização o foi para trazer à tona uma forma correlata à exclusão: por exemplo, o desqualificado. Devemos ver que as engrenagens responsáveis por essas operações são mediações históricas que não escapam ao événementiel. O triste destino nosso no Ocidente é o de nos depararmos em qualquer canto com um tipo de saber agente de uma construção de inteligibilidade, arraigado, desde a sua constituição, nesta trama tão complexa e apertada que perpassa o saber da ciência, do Estado, das práticas, o saber ignorado, enfim, o saber pautado numa relação de força. Saber este que compele a um umbral de passagem, de situação, de condições para o vir-a-ser, contanto que a sua fundação mesma não escape às suas regras.

Em que pese tais termos, na prática, é possível vermos o que acarreta todo este contexto indubitavelmente abrangente, notável em dois níveis. No primeiro, torna-se inegável que a própria maneira pela qual o saber foi estruturado no Ocidente revela os aspectos de suas aplicações como estratégias cujos propósitos vão ao encontro de um "mundo do regulamento indefinido, do regulamento permanente, do regulamento perpetuamente renovado, do regulamento cada vez mais detalhado" ${ }^{, 0}$. O refinamento e progressão desta vitalidade regulamentar não se explicam somente pela disposição de um saber que se orienta numa direção concreta, porém ainda mais por qualquer princípio, regra, lei ou discurso cujos funcionamentos móveis, permanentes, parciais ou detalhados são voltados para uma realização qualquer. Em um segundo nível, o saber disparará um tipo de agenciamento tão eficaz que será capaz de criar condições para um ordenamento tão profundo e permanente do tempo, das atividades, gestos e das aplicações distintas dos saberes. A regulamentação, assim, nos colocará no mundo da ordem; de "uma ordem pela qual os corpos não são senão superfícies a atravessar e volumes a trabalhar, uma ordem que é como uma grande nervura de prescrições, de sorte que os corpos sejam assim parasitados e perpassados pela ordem"71. É deste prisma, aliás, que confluirão as técnicas e tecnologias políticas como instrumentos de toda forma sob a qual a matéria potencial a ser trabalhada em favor de uma subjetividade, os corpos individuais e coletivos sofrerão as efetivações determinantes de forças. Não obstante, também é sob esta

\footnotetext{
${ }^{69}$ Ibidem, p. 215

${ }^{70}$ FOUCAULT, M. Sécurité, territoire, population, p.348.

${ }^{71}$ FOUCAULT, M. Le pouvoir psychiatrique, p.04.
} 
perspectiva que somos incitados a manter vivo o caráter problematizador da sujeição interminável inerente a estes processos. Mas como assim?

A julgar que se coaduna com o saber um sistema de nervura de prescrições, seguindo o pensamento de Foucault, podemos dizer, imantados pela força da mesma metáfora, que a norma seria a parte central, a própria medula espinhal de onde se irradiam as relações produtivas do saber-poder, das mais evidentes até as mais capilares formas de vínculos prescricionais. Sem dúvida regulamentação, ordem e disciplina são costuradas pelo idêntico alinhavo. Tanto é assim que "a norma é o que pode tanto se aplicar a um corpo que se quer disciplinar quanto a uma população que se quer regulamentar”. Donde, ainda a este propósito, "a sociedade de normalização é uma sociedade em que se cruzam, conforme uma articulação ortogonal, a norma da disciplina e a norma da regulamentação" ${ }^{72}$. Importa notar nesta passagem o caráter de ligação, espécie de dobradiça viva, a partir de um elemento que circula entre o disciplinar e o regulamentador, ou seja, a norma se aplicando tanto ao corpo quanto à população; ainda mais, atuando no âmbito das técnicas tanto como das tecnologias, pois aquelas se referirão a todos os tipos de processos imbuídos na relação produtiva com corpos individualizados; enquanto estas, aos arranjos e ordenações coletivas que dão sentido a um grupo implicado nas conseqüências de uma ordenação.

Então deve estar claro, neste sentido, que a norma se exerce em relação aos domínios a que se aplica. Mas para esta empreitada subjaz toda série de exigências e até mesmo de coerções que, respaldada pela situação disciplinadora do saber, de antemão, projeta a norma para a congruência do poder, melhor dizer, de ações produtivas, pois se tratarão de ações qualificadoras, restritivas, incitantes, disciplinares, veridiccionais, corretivas, enfim, ações que dão azo ao uso e aplicação de uma força formadora. Esta perspectiva, sem dúvida alguma, invoca outra vez a dimensão política na qual estamos envoltos, pois a norma, por conseguinte, "não é simplesmente um princípio, não é nem mesmo um princípio de inteligibilidade; é um elemento a partir do qual certo exercício do poder se acha fundado e legitimado" ${ }^{\text {73 }}$. Todavia isto não representa o estatuto de legitimação consignado às equações de racionalização política no aspecto do reconhecimento legítimo de determinado exercício do poder. Ademais, não é do viés da identificação autêntica interposta nas práticas contratuais que se trata; muito menos ainda de um tipo de emanação de poder soberano. Diferentemente de tais proposições, a nossa interpretação contempla o estatuto original do saber como a instância responsável por engendrar um tipo de poder que se legitima por intermédio da aplicação do próprio saber.

\footnotetext{
${ }^{72}$ FOUCAULT, M. Em defesa da sociedade, p.302.

${ }^{73}$ FOUCAULT, M. Os anormais, p.62
} 
Como o saber é o canal livre para o tráfego da norma, ali ela não apenas encontra a sua fundação como se legitima à medida que o saber se aplica, ou seja, opera um jogo de forças. Para nós, aliás, é esta tomada que permitiu a Foucault construir toda uma analítica autêntica do poder, já que pressupõe o intercâmbio incessante entre saber-norma-poder.

Como, contudo, poderíamos tentar estabelecer um bom termo para a norma? Se as possibilidades são tantas no entalhe de sua definição, não é por inconsistência ou articulação precária de sua formação, mas pela abrangência de seu domínio. Ou sob uma expressão original: devido à ampla e singular inflação normativa implicada na própria norma ${ }^{74}$. Há, porém, no contexto do curso de 1974-1975, denominado Os anormais, uma importante referência à norma que para nós é bem completa e clara. Antes, porém, de chegarmos a ela, é fundamental manifestarmos aqui como acolhemos esta proposição.

Não abrimos mão da convicção acerca de que a década de setenta será marcada pela dupla e sináptica questão de como os indivíduos e grupos são conduzidos no Ocidente. Quer dizer, como há uma rede de construção de apoios, formas, mecanismos, instituições, saberes, para nos valermos de apenas algumas indicações, que se voltam para o controle, o cuidado, a optimização das forças produtivas, a disciplina, enfim, para o governo/condução, que implicam em submeter indivíduos e populações a certas condições e regras.

Concomitantemente, e mesmo para amadurecer tal enfoque, Foucault começa a sublinhar de modo insistente a indissolubilidade do saber com o poder, como o curso de 19731974 demonstrará à guisa de toda argumentação que toca $O$ poder psiquiátrico. A medicina psiquiátrica, tal como as demais, estatuem um tipo de saber cujo respaldo prático vai ao encontro de medidas comuns. Por isto mesmo, a definição de norma trará a lume a aplicação de um saber cujo estatuto científico incide completamente sobre as "condutas normais e anormais" $" 75$.

Sendo assim, a norma se traduz como senha polivalente, cujo alcance se fia e dispõe-se "como regra de conduta, como lei informal, como princípio de conformidade". E justamente por se tratar de regra, a sua razão de ser, sempre como referência que se institui de modo objetivado, confronta-se com "a irregularidade, a desordem, a esquisitice, a excentricidade, o desnivelamento, a discrepância". Seja qual for o seu aparato, a norma age e reage "como

\footnotetext{
${ }^{74}$ A expressão é de Ewald e julgamos enriquecedor trazer aqui a sua interpretação. Por ela, podemos bem notar a norma como princípio de valoração a nos situar numa "singular inflação normativa que vai cortar uma multiplicidade de domínios técnicos e econômicos, como o conjunto das ciências morais, jurídicas e políticas que vão se refletir como ciências normativas". Deste modo, "a higiene, o urbanismo, a segurança, em matéria de poluição ou de energia nuclear, a qualidade dos produtos como a proteção dos consumidores, tudo isto procederia, indefinidamente, das decisões normativas" (EWALD, F. Michel Foucault et la norme. In. GIARD, L. (Dir.) Michel Foucault: lire l'oeuvre. Grenoble: Editions Jérôme Millon, 1992, p. 202 e 203).

${ }^{75}$ FOUCAULT, M. Os anormais, p.391.
} 
regularidade funcional, como princípio de funcionamento adaptado e ajustado". É desta concepção, então, que submerge todo tipo de "“normal' a que se oporá o patológico, o mórbido, o desorganizado, a disfunção" ${ }^{76}$. A norma representa a aplicação constante de um exame perpétuo, visando um campo de regularidade, no interior do qual vai se avaliar sem cessar cada indivíduo para saber se está conforme a regra, a norma que definiu a sua finalidade. Outrossim, dada a sua capacidade de produzir uma finalização que foi trabalhada pelas aplicações rigorosas de controle e disciplina, a norma também institui uma referência regular com o intuito de fazer conformar a esta referência um grupo qualquer. Assim, a compreensão signalética da finalização da norma, ou seja, os efeitos que ela obtêm, será ou a normação (normation), no primeiro caso, ou a normalização (normalisation), no segundo, pois a norma está para a invenção e aplicação tanto das técnicas quanto das tecnologias positivas de poder. E isto representa duas situações distintas, embora não totalmente estranhas uma à outra.

Com efeito, normação se dá por meio de todos os processos disciplinares que, apoiados, interpenetrados, margeados pela norma - sem ignorarmos que toda "lei se refere a uma norma", que "a lei tem um papel e função de codificar a norma, de operar em relação a norma uma codificação",77 - forja e alcança para seus objetos o estatuto de normal. Assim, "a disciplina normaliza", por quatro motivos. Primeiro, porque ela "analisa, decompõe, decompõe os indivíduos, os lugares, os tempos, os gestos, os atos, as operações. Ela os decompõe em elementos, que são suficientes para serem percebidos de um lado e modificados de outro". Segundo, "a disciplina classifica os elementos assim percebidos em função de

\footnotetext{
${ }^{76}$ FOUCAULT, M. Os anormais, p.204 para todas as citações. Embora o foco encontrado na obra de Canguilhem, $O$ normal e o patológico, seja totalmente distinto daquele trabalhado por Foucault, acentuando "que não se ditam normas à vida" dada a inexistência de uma patologia objetiva, pois a "vida é essa atividade polarizada de conflito com o meio, e que se sente ou não normal, conforme se sinta ou não em posição normativa", donde o "homem normal é o homem na natureza", podemos encontrar algo que nos ajuda a iluminar esta problemática da norma mesmo em Foucault (CANGUILHEM, G. O normal e o patológico. Rio de Janeiro: Forense Universitária, 2006, p.174 e 234). Cerca de vinte anos após a publicação de $O$ normal e o patológico, Canguilhem elabora algumas Novas reflexões referentes ao normal e ao patológico. Em uma delas, intitulada Do social ao vital, lemos algo de extrema importância: "quando se sabe que norma é a palavra latina que quer dizer esquadro e que normalis significa perpendicular, sabe-se praticamente tudo o que é preciso saber sobre o terreno de origem do sentido dos termos norma e normal, trazidos para uma grande variedade de outros campos. Uma norma, uma regra, é aquilo que serve para retificar, pôr de pé, endireitar. 'Normar', normalizar é impor uma exigência a uma existência, a um dado, cuja variedade e disparidade se apresentam, em relação à exigência, como um indeterminado hostil, mais ainda que estranho"(Ibidem, p.201). Ora, são as normas presentes nos tecidos sociais, inventadas e aplicadas com o intuito de impor uma exigência a uma existência, que faz da norma uma peça mais do que fundamental para se chegar à compreensão de que o sujeito na história ocidental é tramado sob as longas e contínuas linhas que multiplicam as regras aplicadas sobre ele. Poderíamos ainda dizer que as normas revivem a história dos limites de nossa cultura, como já desenvolvemos no primeiro capítulo deste trabalho. História, por sua vez, que "traça um limite", "uma divisão original", como Foucault já colocava em 1961 (Cf. Préface. Dits et Écrits I, No 04, 1961, p.161).

${ }^{77}$ FOUCAULT, M. Sécurité, territoire, population, p.58.
} 
objetivos determinados". Isto quer dizer que ela se instala por adestramento para obter os melhores gestos, posturas e atividades, a fim de empalmar os melhores resultados. Então, e por conseguinte, a "disciplina estabelece as seqüências ou as coordenadas melhores possíveis" a se fazerem sentir no "encadeamento de uns gestos com outros: como repartir os soldados para uma tarefa, como distribuir as crianças escolarizadas nas hierarquias e no interior de uma classificação", ou seja, como comparar, diferenciar, hierarquizar, homogeneizar, excluir. Finalmente, "a disciplina fixa os procedimentos de adestramento (dressage) progressivo e de controle permanente e, enfim, a partir daí, estabelece a divisão entre aqueles que serão considerados como inaptos, incapazes e os outros". Em termos simples, ela faz a divisão do normal e do anormal. Trata-se, portanto, "mais de uma normação que de uma normalização" quando o "fundamental e primeiro na normalização disciplinar não é o normal e o anormal, mas a norma", ou seja, o caráter primitivamente descritivo da norma que, por ser concebida assim, "a determinação e o reconhecimento do normal e do anormal se tornam possíveis"78.

Ao contrário, se os processos de disciplinas partiam de uma norma e, relacionadas às formas de dressages efetuadas pela norma, chegamos a distinguir o normal do anormal, no caso da normalização, observamos exatamente o inverso a propósito das disciplinas. Situando o normal e o anormal a partir da ação da norma que reflete um tipo de identidade produzida, vem à tona um segmento sem "continuidade e sem ruptura", portador de um coeficiente de distribuição e organização que forma um tipo qualquer de população. Nada nos impede, de tal modo, sustentar que a população em Foucault representa “a curva normal” estatuída globalmente a incidir sobre os portadores das condições que se avizinham, que se enquadram nas mesmas estatísticas, sob as valorações aproximativas, no mínimo. Populações diferentes resultam das coabitações diferentes associadas às latitudes estranhas ou afins umas das outras. Aqui, em termos foucaultianos,

vamos ter uma marcação do normal e do anormal, vamos ter uma marcação das diferentes curvas de normalidade, e a operação de normalização consistirá em fazer jogar uns em relação aos outros estas diferentes distribuições de normalidade e a fazer de modo que os mais desfavoráveis sejam conduzidos àqueles que são os mais favoráveis. Temos então aqui algo que parte do normal e que se serve de certas distribuições consideradas como mais normais que as outras, mais favoráveis, em todo caso, que as outras $^{79}$.

Os processos de normalização, portanto, nos fazem partir do que se estabilizou como normal para se deduzir uma norma, quer dizer, um princípio ou prática por intermédio do qual a

\footnotetext{
${ }_{78}^{78}$ Ibidem, p.58-59 para toda a argumentação citada neste contexto.

${ }^{79}$ Ibidem, p.65.
} 
norma se fixa e desempenha um papel operatório focalizado nas divisões dos indivíduos que figurarão no interior de uma certa população, de uma curva normal.

Por esta via, é possível apreender a força onicirculante da norma. Embora seja capaz de plasmar todo tipo de processos negativos, melhor dizer, excludentes, pois tanto o normal quanto o anormal se descolam um do outro, porém, sob outra perspectiva, a norma instaura-se também por um processo positivo que será todo aquele concernente à inclusão que ela é capaz de produzir. Sem demora, então, faz sentido pensarmos que, de fato, "tornamo-nos uma sociedade essencialmente articulada sobre a norma". De um lado, porque a norma "implica um sistema de vigilância, de controle. Uma visibilidade incessante, uma classificação permanente dos indivíduos, uma hierarquização, uma qualificação, o estabelecimento de limites, uma diagnosticabilidade". Logo, para que este círculo se feche, "a norma torna-se o critério da divisão dos indivíduos" ${ }^{\wedge 0}$. Entrementes, porque os indivíduos são imantados sob círculos de normalidades, teremos uma norma que faz reproduzir estes mesmos círculos à medida que denotam a conjugação dos que se situam nas mesmas condições. É a norma aplicada a populações distintas. Assim, Foucault argumenta que,

na época atual, todas essas instituições - fábrica, escola, hospital psiquiátrico, prisão têm por finalidade não excluir, mas, ao contrário, fixar os indivíduos. A fábrica não exclui os indivíduos; liga-os a um aparelho de produção. A escola não exclui os indivíduos, mesmo fechando-os; ela os fixa a um aparelho de transmissão do saber. O hospital psiquiátrico não exclui os indivíduos; liga-os a um aparelho de correção, a um aparelho de normalização dos indivíduos. O mesmo acontece com a casa de correção ou com a prisão. Mesmo se os efeitos dessas instituições são a exclusão do indivíduo, elas têm como finalidade primeira fixar os indivíduos em um aparelho de normalização dos homens. ${ }^{81}$

Muito embora tenhamos aqui associado normalização com população, estamos conscientes de que não nos aproximamos muito fielmente da forma que ela tomará tardiamente lugar no pensamento de Foucault. Mesmo assim, contudo, sustentamos que, antes ainda de se delimitar com clareza e especificidade a população, é possível vislumbrar a associação de grupos de indivíduos como espécie precursora da tecnologia de poder cujo dispositivo de segurança tornará a ser a grande marca da relação normalização-população. Aliás, não mais sob o aspecto de uma regulamentação, é certo, mas de processos de gestão, cujos contornos do biopoder não deixarão de remarcar. O fundamental, porém, a nosso ver, é evidenciar que o papel da relação norma-disciplina foi crucial para que se estabelecessem as estratégias e táticas presentes nos mecanismos aplicados, com o intuito de se conduzir

\footnotetext{
${ }^{80}$ FOUCAULT, M. L'extension sociale de la norme. Dits et Écrits III, No 173, 1976, p.75.

${ }^{81}$ FOUCAULT, M. La vérité et les formes juridiques. Dits et Écrits I, 1954-1975, No 139, 1974, p.1482.
} 
indivíduos e de se formar grupos a partir dos coeficientes de homogeneização. De tal modo, o que deve ser sublinhado é a profusão do poder de normação e normalização presente na extensão social da norma. E, se for assim, não estamos de todo equivocados, já que "a disciplina não foi tão importante e tão valorizada a não ser a partir do momento onde se tentava gerir a população". E o significado disto, ainda a ser apreendido, nos faz pensar não simplesmente em "gerir a massa coletiva dos fenômenos ou geri-los no nível de seus resultados globais; gerir a população significa geri-la igualmente em profundidade, sutilmente e no detalhe" 82 .

Por ora isto nos basta para, enfim, apontarmos o momento decisivo que se impõe. A experiência do sujeito ocidental se constitui na dependência de situações estratégicas em duas frentes: sob a dimensão das forças que individualizam por técnicas e das forças que pluralizam - no sentido de reduplicar o que é celular na abstração de um organismo-população - por tecnologias de poder. A experiência da subjetividade emerge das circunscrições históricas determinantes cujas séries limitaram as condições sob as quais um sujeito pode ser produzido. Do saber já conhecemos a importância neste sentido; mas do poder, não o suficiente. E será justamente por intermédio dele que as relações de forças circularão avidamente, criando, destruindo e recriando os níveis, os aparelhos, os terrenos, as engrenagens, os dispositivos, os indivíduos e as situações responsáveis como condições inexoráveis que se aplicarão na consubstanciação do que se efetivou e do que está para se efetivar, inclusive sob a perspectiva de um vir-a-ser transgressor e disjuntivo. Pelo poder e a despeito dele, o sujeito enquanto forma terminal de força poderá empreender uma aplicação de força sobre si, tentado se dessujeitar. Mas até lá, porém, ainda somos forçados a reconhecer as inegáveis forças que transitam como constituintes históricas de nosso modo de ser. Eis, desta maneira, o horizonte do poder.

Dentre as diversas possibilidades de recepção e tratamento que a problemática do poder nos permite no pensamento de Foucault, julgamos ser a relação com o registro das artes de direção ou condução dos homens, ou simplesmente de governar os homens, a mais interessante para o conjunto de nossa temática. Em nosso juízo, é por este viés que o sujeito ganha contornos por causa das forças históricas que agem e são direcionadas sobre ele como canais de sua constituição. Neste quadro, o uso e aplicação das forças além de mais evidentes tornam-se mais eficazes, de certo, porque "governar é estruturar o campo de ação eventual dos outros". E, desta maneira, é preciso deixar bem claro, “o modo de relação própria ao poder

\footnotetext{
${ }^{82}$ FOUCAULT, M. Sécurité, territoire, population, p.110.
} 
não estaria do lado da violência ou da luta, nem do lado do contrato e da ligação voluntária", mais do que isto, do lado de um "modo de ação singular que é o governo", isto é, de uma ação produtiva a designar "a maneira de dirigir a conduta dos indivíduos e dos grupos" ${ }^{\text {" }}$. Mas, sob que tipo de solo este campo de ação foi estruturado, a ponto de coadunar ação singular com governo? Quais as forças implicadas aí? Que horizonte se delineia sob tal ótica, ou melhor, todo este campo nos conduz aonde?

A tomada destas questões nos compele a uma análise crucial de um recorte histórico que, como queremos sustentar aqui, se dispôs em sua anatomia como base irrevogável das futuras técnicas e tecnologias políticas de condução atuais e, concomitantemente, se estabeleceu como a engrenagem primeira de toda esta arte que se instala no Ocidente e que, por conseguinte, agirá diretamente como força de produção de poder. Referimo-nos à pastoral cristã. Em última instância, por esta temática, acessamos uma chave relevante para compreendermos as razões pelas quais "o homem ocidental aprendeu durante os milênios a se considerar como uma ovelha dentre as ovelhas" $" 84$. Mas isto não significa concebermos uma continuidade ou sobreposição entre a pastoral cristã e o registro das governamentalidades que se desdobram a partir do século XVI, como é bem sabido. Apesar disto e mesmo assim, é possível, segundo Foucault, nos defrontarmos com uma série de "intensificação, multiplicação, proliferação geral" do aspecto emblemático da pastoral que inaugura, refina e multiplica as técnicas de condução, exercendo o seu direito de direção das condutas e pensamentos humanos. E isto tem um alcance significativo, já que "com o século XVI se entra na era das condutas, na era das direções, na era dos governos" $" 85$. Se é claro que a nossa atualidade ainda é completamente eivada pelas conseqüências deste contexto, ou seja, da indelével presença de uma constante governabilidade, ao indagarmos sobre a trajetória das técnicas de condução pelo viés da pastoral, nos defrontaremos com o fio essencial do que poderíamos designar de genealogia de nossa sujeição.

Tomada por Foucault como "a arte de todas as artes, o saber de todos os saberes", a pastoral cristã se estabelece como a "arte pela qual se ensina as pessoas a governar os outros, ou se ensina aos outros a se deixar governar por alguns" $"$. O registro da arte, melhor dizendo,

\footnotetext{
${ }^{83}$ FOUCAULT, M. Le sujet et le pouvoir. Dits et Écrits $I V, \mathrm{~N}^{\mathrm{o}}$ 306, 1982, p.237.

${ }^{84}$ FOUCAULT, M. Sécurité, territoire et population, p.134.

${ }^{85}$ Ibidem, p.237.

${ }^{86}$ Ibidem, p.154. É importante dizer que a expressão "a arte de todas as artes, o saber de todos os saberes", referindo-se à arte de governar os homens pela pastoral, Foucault atribui a Gregório de Nazianzo (329-389/390). Na nota 46, referente à lição de 15 de fevereiro de 1978, do curso Sécurité, Population et Territoire, nos é apresentado o contexto no qual se encontra a expressão de Nazianzo, subtraído de seus Discursos: "Na verdade, parece-me que é a arte das artes (technè technôn) e a ciência das ciências (epistemè epistemôn) de conduzir o ser humano que é o mais diverso e o mais complexo dos seres". Embora o tradutor do fragmento, Laplace, opte por
} 
desta technè, revela tanto as habilidades em jogo na produção da pastoral quanto o seu produto finalizado. Para se exercer diretamente uma forma de dirigir os homens, a pastoral produzirá táticas e estratégias regulares e englobantes capazes de acessar aos mais variados tipos de condutas, a fim de extrair delas algum tipo de relação, de produção de força. Para tanto e grosso modo, produzirá "uma intervenção permanente na conduta cotidiana, na gestação das vidas, mas também nos bens, nas riquezas, nas coisas" ${ }^{\text {} 87}$. E a forma de se obter a sua intervenção consistirá na ativação de três campos distintos que, apesar de suas especificidades, forjam uma zona comum por intermédio da qual a condução torna-se uma arte de governar.

Assim, em primeiro lugar, é preciso levar em consideração que a pastoral cristã põe em xeque um tipo de relação de poder em construção, pois pressupõe um poder de uns sobre outros consignados a um rebanho. A pastoral se exerce, deste modo, essencialmente a partir de alguém que, sob a figura do pastor, conduz, aplicando a sua força não estritamente sobre um território bem delimitado, mas sobre uma multiplicidade em movimento: o rebanho. O poder pastoral, com isto, acompanha os deslocamentos dos seus. Então, como Foucault argumenta, "o rebanho existe pela presença imediata e a ação direta do pastor" ${ }^{88}$, daquele que conduz. Por extensão, vemos emergir um tipo de relação de submissão e servidão integral, já que é o condutor quem porta o saber necessário para conduzir aquele que não pode se perder. Ele escolhe e intermedeia a finalidade a se completar. Um tipo de conhecimento começa a ser processado com o intuito de não permitir que a ovelha se desgarre, abandone o seu território, a trajetória, o vínculo estabelecido com o grupo e o guia. Sendo assim, aquele que dirige não abre mão de uma relação de dependência integral, portanto de uma relação de submissão. Aqui vemos ser sublinhada a submissão de um indivíduo a um outro indivíduo e não a uma lei, a um princípio ou injunção racional tirada da razão. Mas, independentemente disto, "quem é dirigido deve aceitar, deve obedecer”. Na forja de toda esta dependência, e paralelamente,

\footnotetext{
"ciência das ciências" (science des sciences) para epistemè epistemôn, o que de fato é mais próximo do sentido grego, Foucault, ao optar por "saber dos saberes", mais uma vez, põe em relevo a sua forma de instrumentalizar o pensamento. Poderíamos até mesmo dizer que Foucault força um sentido ou forja-o com a intenção de fazer encaixar na ordem de seu pensamento a expressão de Nazianzo. Talvez esta seja mesmo uma crítica possível a ele. Contudo, se levamos em consideração o sentido maior que Foucault atribui ao saber e às implicâncias decorrentes de suas análises, veremos que, de fato, a sua apropriação do termo se justifica na singularidade histórica que propõe. Quer dizer, os saberes atinentes às formas de poder não são instâncias superficiais em nossa constituição, residem nas camadas profundas de séries históricas que, apesar de longínquas, não deixam de ser latentes.

${ }^{87}$ Ibidem, p.157.

${ }^{88}$ FOUCAULT, M. “Omnes et singulatim”: vers une critique de la raison politique. Dits et Écrits IV, № 291, 1981, p.138.
} 
"toda vida integralmente deve ser codificada pelo fato que cada um de seus episódios, cada um de seus momentos deve ser comandado, ordenado por alguém" ${ }^{\text {, }}$.

Em virtude desta relação de dependência integral/submissão, e até mesmo com o intuito de vigorá-la, uma segunda perspectiva se abre com um duplo papel. O estado de obediência devota inaugura um tipo de relação cujo pressuposto fundamental para o seu funcionamento é o reconhecimento humilde de que a vontade própria do indivíduo é sempre equivocada, errônea e desviante. De um modo original, a pastoral cristã, mesmo porque parte da concepção de que o homem é essencialmente mau - de São Paulo ao recrudescimento teológico de Santo Agostinho -, tornará evidente que "ser humilde é, no fundo e sobretudo, saber que toda vontade própria é uma vontade má". Se há, portanto, uma peculiaridade neste tipo de saber que se produz pela necessidade inerente à submissão de obediência, isso se deve pelo fato de que, se há um propósito na obediência, é o da ordem de "um estado de obediência definida pela renúncia, a renunciação definitiva a toda vontade própria" ${ }^{90}$. Mas pensamos que o campo generalizado desta obediência a caracterizar o espaço, no qual vão se desdobrar as relações pastorais, não seria possível sem o papel de um poder benfazejo, ao menos em sua promessa e idealização. Manifestando-se por intermédio de um cuidado, zelo, devotamento e aplicação indefinidos voltados para o rebanho, importará ao pastor cuidar de sua salvação, entendida aqui como a capacidade de o rebanho receber e de lhe ser garantida a subsistência, a proteção contra qualquer perigo e maldade. Então o pastor deve ser considerado superior e, sendo assim, ele é o que velará pelo bem-estar dos seus. E a esta altura Foucault antecipa, por ligação, o longo alcance deste aspecto e nos diz: “o pastor é aquele que vela. 'Vela' no sentido evidente de vigilância (surveillance) do que pode se fazer de mal, porém, e sobretudo, como vigilância (vigilance) a propósito de tudo o que pode acontecer de infelicidade"91.

Aparentemente, os termos poderiam se equivaler, mas não é o caso. Embora seja exigido do pastor dirigir a sua atenção a todo o rebanho, ele não pode permitir que uma só de suas ovelhas lhe escape. Para haver uma vigilance, que é a atenção dispensada a todo o rebanho, será necessária uma surveillance como controle individual. Então “o poder pastoral é um poder individualizante" 92 , pois "supõe uma atenção individual a cada membro do rebanho"93. Podemos dizer que reside, nesta dinâmica, uma paradoxal equivalência da ação pastoral, pois, se de um lado o pastor deve ter o olhar sobre o conjunto, de outro, o mesmo

\footnotetext{
${ }^{89}$ FOUCAULT, M. Sécurité, territoire, population, p.179. Ibidem para a citação anterior.

${ }^{90}$ Ibidem, p. 181 .

${ }^{91}$ Ibidem, p.131.

92 Ibidem, p.132.

${ }^{93}$ FOUCAULT, M. “Omnes et singulatim”: vers une critique de la raison politique. Dits et Écrits IV, № 291, 1981, p.139.
} 
deve ocorrer sobre cada um. O pastor "presta atenção a todos, sem perder de vista ninguém dentre eles. Ele é levado a conhecer o seu rebanho no conjunto e no detalhe" ${ }^{\text {"94 }}$. É pela expressão latina omnes et singulatim que Foucault se apropria desta característica do poder pastoral para nos levar a ver que, de fato, a aplicação infinita de vigilância presente em todo tecido social é devedora desta arte que, antes de tudo, procurou agir de modo particularizante. Não à toa, o argumento foucaultiano sustentará, com ousadia, que o omnes et singulatim "será precisamente o grande problema das técnicas de poder no pastorado cristão e das técnicas de poder modernas", notadamente as que nos conduziram às "tecnologias da população" 95 .

Ora, ainda a este propósito, não podemos então ignorar que se processou, desde a mais incipiente forma deste tipo de poder, "um modo de individualização que não somente não passa pela afirmação de um eu (moi)" do indivíduo, uma vez que a vontade de quem guia prevalece como prescrição de lei, com o intuito de garantir o cuidado do outro pela via da submissão constante, mas, além disto, todo este processo também acarretou na constante "destruição do eu"96. Com efeito, é o problema da verdade que doravante se ritualiza. Enquanto técnica, ou melhor, arte, o poder pastoral atua sobre o indivíduo e a coletividade necessariamente para ensinar, isto é, para assegurar o acesso a um tipo de verdade. $\mathrm{O}$ uso deste dispositivo se dá pela construção de uma rede de alianças, de comunicações e de pontos de apoios que modularão o cotidiano dos que se submetem "a uma observação, uma vigilância, uma direção exercida a cada instante e de maneira menos descontínua possível sobre a conduta integral, total, das ovelhas". Isto ocorre porque um saber perpétuo que será o saber do comportamento e das condutas se organiza de modo exaustivo, a fim de assegurar a "direção da consciência" ininterruptamente. Embora esta temática não seja exclusiva do

\footnotetext{
${ }^{94}$ Ibidem, Id.

${ }^{95}$ FOUCAULT, M. Sécurité, territoire, population, p.132. É preciso esclarecer alguns aspectos para que tenhamos um cuidado de não colocarmos numa vala comum a diversidade implicada na noção de pastoral cristã nem sofrer o risco de uma sobreposição imediata e tomada como totalidade à guisa da tecnologia de poder moderna, que para Foucault significa atual. É claro que Foucault tem consciência de que o "termo cristianismo não é exato e recobre uma série de realidades diferentes", e equivale a dizermos o mesmo para a pastoral cristã. Mas, ao ressaltá-la como o faz, leva em conta, sim, "que a pastoral começa com um certo processo que é absolutamente único na história e que não se encontra outro exemplo em nenhuma civilização: processo pelo qual uma religião, uma comunidade religiosa se constituiu como Igreja, quer dizer, como uma instituição que pretende governar os homens em sua vida quotidiana sob o pretexto de conduzi-los a uma vida eterna em outro mundo, e isto em uma escala não apenas restrita a um grupo definido, não apenas a uma cidade ou um Estado, mas à humanidade inteira". Dado este estatuto, Foucault julga que a pastoral cristã representa um dos traços mais marcantes na história das sociedades, e que, justamente por esta forma, "representa um dispositivo de poder encontrado em nenhuma outra parte, um dispositivo de poder que não cessou de se desenvolver e de refinar durante quinze séculos, digamos desde o II e III séculos depois de Jesus Cristo até o século XVIII de nossa era". Logo "o poder pastoral em sua tipologia, em sua organização, em seu modo de funcionamento, o poder pastoral que se exerceu enquanto poder é sem dúvida algo do qual nós ainda não nos livramos" (Cf. Sécurité, territoire, population, p.151-152).

${ }_{96}$ Ibidem, p. 183 .
} 
cristianismo, tampouco por ele inventada, a direção da consciência cristã se distingue da Antiguidade, por exemplo, pelo fato de não se dar no registro da voluntariedade do indivíduo. Na pastoral, este tipo de direção se instaura de modo obrigatório, portanto não voluntário; contínuo, ou seja, não é meramente circunstancial, pois atravessa todos os aspectos da existência; de igual modo, "não tem por função garantir ao indivíduo o domínio sobre si mesmo", ao contrário, irá circunscrevê-lo à dependência constante do condutor ou guia: o diretor de sua consciência. Sob esta ótica, vemos formar um tipo de exame ininterrupto a extrair e forjar certos discursos de verdade sempre intermediados por quem exerce a função de conduzir. Por conseguinte, a verdade estará sempre ligada àquele que dirige a consciência. Então a pastoral cristã, valendo-nos dos termos foucaultianos, inova completamente ao colocar em foco

\begin{abstract}
uma estrutura, uma técnica ao mesmo tempo de poder, de investigação, de exame de si e dos outros pelo qual uma certa verdade, verdade secreta, verdade do interior, verdade da alma escondida, será o elemento pelo qual se exercerá o poder do pastor, pelo qual se exercerá a obediência e será garantida a relação de obediência integral. ${ }^{97}$
\end{abstract}

Mas é preciso acrescentar que o instrumento primordial na consecução tanto da extração da verdade quanto de uma pedagogia da verdade, ou seja, a intenção produzida e atingida por intermédio de uma direção que, de fato, ensina de sua exterioridade como o modo de ser correto é objetivado, encontrará o seu acabamento na modalidade de poder mais vertiginosa e refinada da pastoral: a confissão. O que nos interessa aqui não é toda série histórica em suas continuidades e descontinuidades que se interpõem na história da confissão, mas a percepção de como este procedimento tornou-se a chave fundamental de toda cartografia do corpo do homem ocidental à medida que o incitava à busca da verdade, a um tipo de relação costurada entre o desnivelamento da qualificação do próprio confessor e da desqualificação do confessante - proto-especialização do saber -; à constante dependência do outro para se chegar ao remédio, cuja dor, mal, pecado, medo, fantasia, desejo se revelavam em meio ao "imenso relato total da existência" - protomedicalização ocidental -; enfim, confissão como fisiologia moral da carne, investimento vigilante, policiamento a incidir como controle desde a obrigatoriedade da confissão, que opera os seus códigos, as chaves de acesso ao que está velado, desconhecido. Pela confissão, emerge uma técnica cuja regularidade, continuidade e exaustividade, segundo a interpretação de Foucault, fará deste modo de exercício de poder uma importante peça para se produzir, da condução como arte de governo à

\footnotetext{
${ }^{97}$ Ibidem, p.186. As demais citações deste parágrafo: opus cit, p.185-6.
} 
ciência como saber qualificado, "procedimentos para analisar, reconhecer, guiar e transformar" 98 .

Se, contudo, impõe-nos a necessidade da definição, podemos dizer que a confissão se organizou e estruturou-se como a

obrigação de fazer passar regularmente pelo fio da linguagem o mundo minúsculo de todos os dias, as faltas banais, as falhas mesmo imperceptíveis e até o jogo problemático dos pensamentos, das intenções e dos desejos; ritual de confissão em que aquele que fala é ao mesmo tempo aquele de que se fala; apagamento da coisa dita por seu próprio enunciado, mas igualmente aumento da confissão por ela mesma que deve permanecer secreta, e não deixar atrás dela nenhum traço a não ser o arrepender-se e as obras da penitência ${ }^{99}$.

É desta estridente relação de poder, amparada na rede inevitável de uma discursividade que se produz pelo incitamento, que a confíssão se torna marca inconfundível de nossa cultura. Claro, não era o ato em si de se enunciar pela fala que contava, mas a realidade que se atingia por esta estratégia. A confissão colocou-nos no âmbito da produção de realidade. Nela, aquilo que o sujeito enuncia o faz criando não apenas para si próprio, à medida que revela o que é, o que tem, mas, sobretudo, para um outro. A confissão é, assim, um procedimento incontornável das produções de verdade. Melhor dizendo, "a confissão da verdade se inscreveu no cerne dos procedimentos de individualização do poder, desde então nos tornamos uma sociedade singularmente confessada" $" 100$.

98 FOUCAULT, M. Os anormais, p.242. A argumentação desenvolvida neste parágrafo acompanha o pensamento do filósofo francês na lição de 19 de fevereiro de 1975 deste mesmo curso.

${ }^{99}$ FOUCAULT, M. La vie des hommes infâmes. Dits et Écrits III, No 198,1977, p.245.

${ }^{100}$ FOUCAULT, M. História da sexualidade I: a vontade de saber, p.58-59. Mais do que uma sociedade confessada, Foucault pensa que "o homem, no Ocidente, tornou-se um animal confidente". Atento aos efeitos gerais da confissão, o nosso autor sustentará que a confissão difundiu seus efeitos "na justiça, na medicina, na pedagogia, nas relações familiares, nas relações amorosas, na esfera mais cotidiana e nos ritos mais solenes; confessam-se os crimes, os pecados, os pensamentos e os desejos, confessam-se passado e sonhos, confessam-se a infância; confessam-se as próprias doenças e misérias; emprega-se a maior exatidão para dizer o mais difícil de ser dito; confessa-se em público, em particular, aos pais, aos educadores, ao médico, àqueles a quem se ama; fazem-se a si próprios, no prazer e na dor, confissões impossíveis de confiar a outrem, com o que se produzem livros. Confessa-se - ou se é forçado a confessar" (Cf. opus cit, p.59). A nosso ver, vemos nesta formulação uma espécie de cunho estruturalista, pois nos conduz à incontornabilidade da presença-ação da confissão. Entretanto este não é o ponto aqui a ser ressaltado. É preciso levar em consideração, e isto confirma ainda mais a nossa tese, que Foucault está levando às últimas conseqüências as mediações de sujeição nas quais estamos implicados. É possível enxergarmos isto na interpretação que Gros dispensa à questão. Para este comentador, a confissão enquanto "maneira de submeter o indivíduo, requerendo-se dele uma introspecção indefinida e o enunciado exaustivo de uma verdade sobre ele mesmo", põe à mostra que "o destino do sujeito verdadeiro no Ocidente estará fixado, e procurar sua verdade íntima será sempre continuar a obedecer. Mais genericamente, a objetivação do sujeito em um discurso verdadeiro não adquire historicamente sentido senão a partir desta injunção geral, global, permanente de obedecer: somente sou sujeito da verdade, no Ocidente moderno, no princípio e no termo de uma sujeição ao Outro" (GROS, F. Situação do curso. In. A hermenêutica do sujeito, p.617. Grifos nossos). Então, do nosso ponto vista, será um tipo de afrontamento a ser produzido diante de toda esta estrutura, que nos permitirá vislumbrarmos a possibilidade de um sujeito que constitua a sua subjetividade não pela força deste Outro, mas a partir de si mesmo, como veremos. 
Situada desta maneira, julgamos encontrar na pastoral uma série de técnicas e procedimentos tanto visando a individualização quanto a totalização em seus efeitos inevitáveis, cuja finalidade inexorável se dirigiu para a condução dos homens. Três conseqüências ganharão terreno desde esta perspectiva histórica que se nos impôs. De imediato, e fazemos questão de insistir neste ponto, a pastoral orientou-se e deu lugar
a toda uma arte de conduzir, de dirigir, de levar, de guiar, de ter em mão, de manipular os homens, uma arte de segui-los e de forçá-los passo a passo, uma arte que tem esta função de tomar sob sua responsabilidade os homens coletivamente e individualmente ao longo de toda vida e a cada passo da existência. ${ }^{101}$

Com isto, assinalamos para uma importante genealogia da história da sujeição, inegável em seu papel nas distribuições de forças presentes nas relações que envolviam a perspectiva que cada um passou a ocupar, função subjetivante, portanto; e notável em sua presença mutante ao longo das formas assumidas a fim de garantir a sua proeminência nos vínculos de dependência/submissão integral, exame perpétuo e produção de verdade pela confissão exaustiva, vigilância e ordenação ininterruptas.

Em segundo lugar, há uma conseqüência de fundo que toca a questão central mesmo da história do sujeito. Como a pastoral inaugura uma forma de poder absolutamente original que, a rigor, produzirá por suas técnicas um modo específico de individualização, ou seja, o indivíduo sob ações de forças como pressuposto idiossincrático da subjetividade ocidental, vemos definir uma "identificação analítica" do indivíduo sob a dependência de um exercício de poder desnivelado pela qualificação e desqualificação de quem conduz e quem é conduzido. Isto representa que a individualização não é "definida pelo estatuto do indivíduo ou por seu nascimento ou pela explosão de suas ações", ao contrário, por um "jogo de decomposição" a definir a cada instante o que ele merece ou não, pois foge de seu alcance o saber conduzir-se. Como nisto estará subsumido não mais "uma afirmação de si sobre si, mas toda uma rede de dependências (servitudes), que implica a dependência geral de todo o mundo em relação a todo mundo", e, ao mesmo tempo, como se isto não bastasse, "a exclusão do eu, a exclusão do ego, a exclusão do egoísmo como forma central, nuclear do indivíduo", então, sob este horizonte, podemos dizer, deparamo-nos com uma "individualização por sujeitamento". Com efeito, sendo assim, salta aos olhos que a individualização como condição prévia do governo dos vivos não vai ser "obtida por uma verdade reconhecida" a partir do próprio indivíduo, já que este é produto de uma força que age sobre ele. Será obtida, outrossim, "pela produção de uma verdade interior, secreta e escondida", cuja forja, porém,

${ }^{101}$ FOUCAULT, M. Sécurité, territoire, population, p.168. 
coincide com os mecanismos de sua extração. Processo, assim, de subjetivação, designado aqui como a obtenção de um sujeito, ou de uma subjetividade implicada sob relações determinadas de forças, pois "um sujeito é subjetivado pela extração de verdade que se lhe impõe" . Posto isto, podemos afirmar com Foucault que:

identificação analítica, sujeitamento, subjetivação caracterizam os procedimentos de individualização que vão ser efetivamente colocados em obra pela pastoral cristã e pelas instituições da pastoral cristã. Portanto é toda a história dos procedimentos de individualização humana no Ocidente que se encontra introduzida pela história da pastoral. Digamos ainda que é a história do sujeito ${ }^{102}$.

Enfim, a posição cardeal da pastoral como arte de conduzir, hipótese ao mesmo tempo ousada e original de Foucault, irá nos situar no eixo das transformações históricas do uso e aplicação das forças nas formas técnica e tecnológica do poder. Desde longe, a pastoral esboça, constitui o prelúdio, aliás, como momento decisivo das condições marcantes das posições de poder inevitavelmente ligadas ao problema político que é aquele de nossa relação omnes et singulatim. Como nos tornamos sujeitos celulares? Como nos tornamos sujeitos orgânicos? Dispendiosas conseqüências não se cansarão em suas reposições de forças. Nisto, a atualidade desta problemática não nos enganará.

Mas do ponto de vista fundamental de que é preciso "compreender por quais mecanismos somos reencontrados prisioneiros de nossa própria história"103, a constituição do sujeito celular, ou seja, das táticas individualizantes, indicará, desde a pastoral, o solo no qual estamos aterrados, recepcionado aqui como senha de uma remarcação híbrida a ressaltar os tipos possíveis de relação de poder que "passa por nossa carne, nosso corpo, nosso sistema nervoso" ${ }^{104}$, constituindo-nos. Trata-se, em último caso, de uma situação de diagnóstico limite cuja moldura pôs em relevo a inseparabilidade do exercício visível do poder com táticas individualizantes, cujas relações de força focalizaram o corpo como centro das experiências de seus domínios, táticas e estratégias. Assim, movemo-nos, defendendo que, com a pastoral, já encontramos uma rede indispensável de apoio e difusão de poder, todavia sustentadas por dispositivos que acenaram para o engendramento do que Foucault denominou de anatomia política. A este propósito, é preciso considerar que

a "invenção" dessa nova anatomia política não deve ser entendida como uma descoberta súbita. Mas como uma multiplicidade de processos muitas vezes mínimos, de origens diferentes, de localizações esparsas, que se recordam, se repetem, ou se imitam, apóiam-

\footnotetext{
${ }^{102}$ Ibidem, p.187. Toda argumentação citada aqui se situa loco citato.

${ }^{103}$ FOUCAULT, M. Le sujet et le pouvoir. Dits et Écrits IV, №306, 1982, p.225.

${ }^{104}$ FOUCAULT, M. La vérité et les formes juridiques. Dits et Écrits I, 1954-1975, № 139, 1974, p.1508.
} 
se uns sobre os outros, distinguem-se segundo seu campo de aplicação, entram em convergência e esboçam aos poucos a fachada de um método geral. ${ }^{105}$

Em nossa interpretação, cremos que o autor de Vigiar e punir recorre a esta idéia de método geral para a questão da anatomia política, pelo fato de ela incidir - não importando o nuançar de sua localização, multiplicidade e registro - sobre o corpo tomado como unidade individual, a sofrer as ações de certas forças. Estas ações estarão sempre no registro da técnica, ou seja, de uma arte produtora do "corpo humano" que entra, doravante, "numa maquinaria de poder que o esquadrinha, o desarticula e o recompõe" ${ }^{106}$. O corpo não é, deste modo, pressuposto para a ação do poder, mas, inversamente, torna-se o veículo de sua força, à medida que é constituído por ele a partir de processos empíricos e refletidos para controlar ou corrigir as suas operações. Assim, o corpo é efeito das incidências de forças articuladas sobre ele. Tanto é que, com as técnicas de controle, é possível trabalhar o corpo em seus detalhes ou, em termos mais precisos, "de exercer sobre ele uma coerção sem folga, de mantê-lo mesmo no nível da mecânica - movimentos, gestos, atitude, rapidez: poder infinitesimal sobre o corpo ativo" ${ }^{107}$. É claro que se depreende deste tipo de ação uma espécie de economia, cuja finalidade repousará não apenas na eficácia das intenções a serem atingidas, mas nos meios otimizados, a fim de assegurar a sua melhor utilização. A chave da anatomia política reside na arte da produção do corpo humano em todos os seus detalhes. É a partir justamente das séries de técnicas sempre minuciosas e por vezes íntimas que definem certo modo de investimento político e detalhado do corpo que a expressão microfísica do poder encontrará o seu sentido. Esta idéia sintetiza as relações particulares de submissão, controle e extração de eficácia, com o propósito de se atingir "um corpo que pode ser submetido, que pode ser utilizado, que pode ser transformado e aperfeiçoado" 108 individualmente.

No âmbito da história dos sujeitos objetivados por incansáveis processos de individualidade, ou seja, como se processaram as promoções de acessos e materialização de tipos de indivíduos compelidos a certos modos de ser, a arte do corpo, imbuída a partir de seus métodos que "permitem o controle minucioso das operações do corpo, que realizam a sujeição constante de suas forças e lhes impõem uma relação de docilidade-utilidade", irá nos situar no "momento histórico das disciplinas"109. Tamanha sanha colocada na ordem da produção,

\footnotetext{
${ }^{105}$ FOUCAULT, M. Vigiar e punir, p.127.

${ }^{106}$ Ibidem, Id.

${ }^{107}$ Ibidem, p. 126.

${ }^{108}$ Ibidem, Id.

${ }^{109}$ Ibidem, p.126 e 127.
} 
sempre ligada a uma força a extrair um produto, permite-nos mesmo afirmar que o corpo no tecido social inteiro, doravante, estará sob o horizonte de uma sociedade disciplinar.

Contudo, antes mesmo de escrutar o que decorre desta afirmação, é preciso notar que a anatomia política desenvolve seus efeitos não apenas a partir de uma ação sobre o corpo, mas também pelo próprio fundamento que a concepção de poder-saber auspiciosamente pontifica enquanto força produtora. Nesta chave, isto quer dizer que "o indivíduo é um efeito do poder e é, ao mesmo tempo, na medida em que é um efeito seu, seu intermediário", ou seja, "o poder transita pelo indivíduo que o constituiu" ${ }^{\prime 10}$. De um lado, porque o modo de o poder se exercer subsume-se a um saber que o legitima. A partir do momento que é a vontade de outrem que se configura na relação entre indivíduos, necessariamente as técnicas de poder se voltam para "dirigi-los de maneira contínua e permanente", é dizer que, de forma global, "certos homens podem mais ou menos inteiramente determinar a conduta de outros homens" "111. Que haja um reduplicar sob o manto inesgotável das ações de uns sobre outros é evidente quando pensamos em toda sorte de relações de sujeição estritamente imbricadas em experiências que, apesar de distintas, operam sob os mesmos mecanismos. Então, de outro lado, todo tratamento dispensado ao que se pretende corrigir, quer seja em seu comportamento, em sua doença, em seu estado mental, em sua postura social ou em seu desejo, demanda o confronto com uma realidade para qual ele "se deve dobrar e pela qual ele deve ser subjugado", porque "é o outro, enquanto centro (centre) de vontade, enquanto lugar de origem (foyer) de poder" ${ }^{\prime 12}$ que aciona uma força cujos efeitos serão não apenas a verdade que se constitui e forma-se, como meio de se chegar e se justificar uma ação, mas todo composto que se concretiza como atitude, ou seja, o próprio comportamento.

A anatomia política, no entanto, não se restringe à forja da exterioridade do comportamento. Levada às últimas conseqüências, esta conjuntura também trabalhará na própria constituição da percepção subjetiva do indivíduo, estruturando a sua interioridade, ou seja, formando mesmo a sua capacidade de responder e interagir com todo tipo de arranjo de forças focalizado sobre ele. Como a questão envolve "uma política das coerções que são um trabalho sobre o corpo, uma manipulação calculada sobre seus elementos, de seus gestos, de seus comportamentos" $" 113$, então, a nosso ver, o sentido que Foucault passa a dar à idéia de alma sintetiza o quanto "as disciplinas de poder aplicadas aos corpos haviam feito sair desses

\footnotetext{
${ }^{110}$ FOUCAULT, M. Em defesa da sociedade, p.35.

${ }^{111}$ FOUCAULT, M. "Omnes et singulatim": vers une critique de la raison politique. Dits et Écrits IV, № 291, 1981, p.136 e 160.

${ }^{112}$ FOUCAULT, M. Le pouvoir psychiatrique, p.173.

${ }^{113}$ FOUCAULT, M. Vigiar e punir, p.127.
} 
corpos sujeitados algo que era uma alma-sujeito, um 'eu', uma psique" ${ }^{\text {114 }}$. Por mais que a formulação seja obscura e talvez também generalizante, o que vemos é uma indicação de que, na cultura das relações de poder, o que podemos compreender como a subjetividade mais profunda e até inacessível do homem não passa de uma superfície permanentemente produzida. A alma é a correspondente descontínua de cada tipo distinto de força que se aplica aos indivíduos, dependendo de quem os conduziu, de qual verdade foi infringida a eles, de qual expectativa foi trabalhada como resultado final desejado, de qual condução se processou. É neste sentido que uma "alma" habita o homem "e o leva à existência, que é ela mesma uma peça no domínio exercido pelo poder sobre o corpo. A alma, efeito e instrumento de uma anatomia política; a alma, prisão do corpo"115.

O cuidado e a cautela que devemos ter neste contexto não são de importância menor. Ao aproximar a perspectiva da alma pela via da anatomia política, não estaria Foucault se equilibrando em uma perigosa linha cujo traçado lembraria todo o jogo de repressão existente na cultura ocidental e, assim, se aceitamos a fatura do poder como relação de forças e produção como ele defende, suscitando uma perigosa contradição? Como poderia ser, então, o poder não repressor, se a alma tornou-se prisão do corpo? É preciso entender, numa escala maior, que é evidente o papel das coerções na constituição dos sujeitos, a norma mesmo atesta isto. As interdições não são ilusões ou miragens, mas espreitam, com todo seu aparato de "proibições, recusas, censuras, negações", as zonas que pretendem se afastar das regulamentações. Apesar disto, porém, elas "são apenas peças que têm uma função local e tática numa colocação discursiva, numa técnica de poder, numa vontade de saber que estão longe de se reduzirem" "116 ao mero campo repressor. A repressão, assim, não é negativa estritamente, pois permite vincular a intensificação dos poderes à multiplicidade do discurso e das práticas que, então, mais uma vez, estão ali para produzir. É desta maneira que a recorrência à alma provoca uma inversão de deslocamento do repressor para o patamar da produção. Afirmar isto é, então, entender que alma-corpo, fusão precípua e indiscriminada,

tem uma realidade, que é produzida permanentemente, em torno, na superfície, no interior do corpo pelo funcionamento de um poder que se exerce sobre os que são punidos - de uma maneira geral sobre os que são vigiados, treinados e corrigidos, sobre os loucos, as crianças, os escolares, os colonizados, sobre os que são fixados a um aparelho de produção e controlados durante toda a existência. ${ }^{117}$

\footnotetext{
${ }^{114}$ FOUCAULT, M. Em defesa da sociedade, p.221.

${ }^{115}$ FOUCAULT, M. Vigiar e punir, p.31-32.

${ }^{116}$ FOUCAULT, M. História da sexualidade: a vontade de saber, p.17.

${ }^{117}$ FOUCAULT, M. Vigiar e punir, p.31. Ora, o que precisa, de fato, ficar claro é uma certa coerência de perspectiva quanto a esta questão. Se a anatomia política, como argumenta Ewald, "faz aparecer o poder como produtor", é porque ela "é 'economia política' no sentido da análise dos modos de produção de poder, e
} 
Posto isto, resta saber ainda como esta produção permanente, invocada acima por Foucault, opera de tal modo que a "alma", com tudo que representa, transuma pelo corpo, suturando-o a ela e convergindo-se para uma anatomia política. No fundo, toda a questão circula pelas engrenagens do poder disciplinar, que "fixa exatamente a função-sujeito sobre o corpo" ${ }^{118}$. Esta afirmação é de suma importância, pois, como pensamos, porta a idéia de que a existência do sujeito não preexiste a nenhum processo de constituição de "singularidade

'economia política' do corpo enquanto os efeitos de poder são obtidos por investimento e sujeitamento do corpo, isto é, produção de corpos, almas, idéias e de saber". Com isto estamos inteiramente de acordo; aliás, pela razão de sustentarmos que a produção mesma do poder se dá na multiplicidade de modos, a pastoral seria um destes modos, o aprisionamento e a internação outros, a medicalização mais um outro modo, enfim. Por isto, quando o próprio Ewald defende a idéia de que "médicos, fisiologistas, especialistas da alma, sempre são apenas fabricantes de almas e de corpos deformados que eles nos dão como a lei de nosso ser "eterno", pois "eles nos fecham sobre nossas deformidades, eles fazem delas nossa prisão", podemos ver que a indicação da produção é evidente. (EWALD, F. Anatomie et corps politiques. In. Critique. Paris: Minuit, Dez. 1975, Tomo XXXI, No 343, p.1239 e 1260). Desta maneira, não podemos consentir com Honneth, quando este sustenta que Foucault, ao admitir "o corpo humano como uma massa energética condicionável ao infinito, sem rosto", arma uma espécie de "dilema teórico no qual ele cai com o conceito quase-behaviorista do corpo" (HONNETH, A. Foucault et Adorno: deux formes d'une critique de la modernité. In. Critique. Paris: Minuit, Ago-Set. 1986, Tomo XLII, No 471-472, p.815). Esta concepção faz sentido a Honneth, pelo fato de este entender que "as operações vitais do corpo humano são violentamente reprimidas por medidas de adestramento e disciplina" (Opus cit, p.811). Para nós, não pode ser assim por dois motivos muito claros. Primeiro, devemos nos certificar de que, se concebermos uma relação entre vida adstrita a operações vitais, como aquele fundo tocado por "necessidades orgânicas, biológicas, que se encontram reprimidas ou suspensas", como já dizia Marcuse (MARCUSE, H. Eros e civilização: uma interpretação filosófica do pensamento de Freud. Rio de Janeiro: Guanabara/Koogan, s/d, p.16), isto é mesmo possível dentro do viés dos frankfurtianos, certamente de onde Honneth se instala para falar. Entretanto não é deste fundo que a vida pode ser compreendida em Foucault. É forçoso dizer que, para ele, "a noção de vida não é um conceito científico, mas um indicador epistemológico classificador e diferenciador cujas funções têm um efeito sobre as discussões científicas, mas não sobre seu objeto". Para nós, isto representa dizer que não é do nível tão somente do adestramento e disciplina que a questão da vida se coloca. O foco seria insistentemente refratário, se é que isto é possível, já que "a essência de nossa vida é feita, depois de tudo, do funcionamento político da sociedade na qual nos encontramos", quer dizer, feita sob os feixes sincréticos encontrados na "sociedade em que vivemos, nas relações econômicas nas quais ela funciona, e o sistema que define as formas regulares, as permissões e as interdições que regem regularmente nossa conduta" (FOUCAULT, M; CHOMSKY, N. De la nature humaine: justice contre pouvoir. In. ELDERS, F (Org.) Sur la nature humaine: compreendre le pouvoir. Interlude. Bruxelles: Les Editions Aden, 2006, p.14 e 52). Parece-nos, ainda a este propósito, que Honneth enxerga o poder sob uma ênfase demasiadamente repressora ou, talvez, sob um estímulo condicionante notadamente negativo. É por esta fresta, em nosso entendimento, que ele conceberá o juízo de um "dilema teórico" em Foucault com um "conceito quase-behaviorista do corpo", e aqui vem a lume nossa segunda objeção. Fora a própria indecisão de Honneth com expressão "quase-behaviorista", lembramos que os estímulos negativos, acercando-nos da própria perspectiva da psicologia behaviorista, não servem sob Foucault, por exemplo, para que a prisão funcione como aversão ou forma de se evitar um comportamento desviante. Nada mais falso do que isto. Não podemos nos esquecer de que Foucault, em Vigiar e punir, demonstra muito bem que "o delinqüente é um produto de instituição", e que, diferentemente de "corrigir" ou estabelecer um comportamento operante - para ficarmos no rez-de-chaussée do behaviorismo -, ele porta uma biografia que atesta o quanto anteriormente passou "por todos esses mecanismos e estabelecimentos dos quais fingimos crer que se destinavam a evitar a prisão" (FOUCAULT, M. Vigiar e punir, p.263). Nestas proporções, é claro, a chave de entendimento é o poder enquanto potência, ou melhor, enquanto relações de forças, pois, assim, nos situamos para além da repressão e chegamos àquele ponto precioso que Deleuze tão bem formulou: o poder "não se reduz à violência, isto é, à relação da força com um ser ou um objeto; consiste na relação da força com outras forças que ela afeta, ou mesmo que a afetam (incitar, suscitar, induzir, seduzir etc: são afectos). (DELEUZE, G. Conversações. São Paulo: Editora 34, p.145).

${ }^{118}$ FOUCAULT, M. Le pouvoir psychiatrique, p.57. 
somática", expressão equivalente a indivíduo, resguardada justamente na intensidade, permanência e exigência que a força aplica a extrair uma função. Mas como isto está envolvido por processos e experiências, toda função indica a instalação de um modo descontínuo e absolutamente múltiplo que demanda um tipo de resposta admitida na propriedade da função. É preciso notar, assim, o inequívoco jogo duplo que tem o seu lugar entre subjetividade conquistada à guisa da função terminal apreendida e o sujeito terminal enquanto "singularidade somática tornada". No caso, é por "mecanismos disciplinares, portadores da função-sujeito, que o indivíduo pôde aparecer no interior de um sistema político", isto é, nas formas precisas em que o "indivíduo se constitui" "119. Mas falar da precisão é, então, explicar o que é a disciplina enquanto poder político-corpo-individual.

De um modo geral, a disciplina se circunscreve sob a nomenclatura de processos históricos, embora heteromorfos e de visadas heterogêneas, a confluir para um objetivo eqüipotente, que é a finalização do indivíduo em seu caráter antropoplástico. Isto significa que ela é uma forma de utilizar e aplicar a força por sinais práticos, administrados e de cunho estratégicos, capazes de instilar disposições, manobras, táticas, técnicas e funcionamentos de poder na obtenção de uma submissão e utilização do corpo de modo contínuo. Podemos dizer que, desta ótica, a sujeição é a priori em todos os seus níveis e ações de consecução. Mesmo porque, ao se tratar de uma relação de poder, temos de ter em mente que é indispensável a presença de dois elementos que justifiquem a própria relação: “que o 'outro' (aquele sobre o qual a relação se exerce) seja bem reconhecido e mantido até o final como sujeito da ação; e que se abra, diante da relação de poder, todo um campo de respostas, reações, efeitos, invenções possíveis" ${ }^{120}$. Ora, será precisamente a partir dos aspectos de controle na obtenção destas respostas, reações, invenções possíveis, como pretende Foucault, que a disciplina assume dimensões ubíquas na esfera da produção de subjetividade. Devemos entender que a disciplina é, então, a conjugação de um determinado poder disciplinar sempre maior com relação ao efeito chegado.

Desta maneira, nunca aportaremos no esgotamento de suas combinações. Entretanto o seu aliciamento, como cremos, não abre mão de uma engrenagem essencial disposta, basicamente, na eficiência do controle do tempo e espaço. Com isto, todo sistema disciplinar tende a ser "uma tomada do tempo em sua totalidade"121. Artificial realidade, o tempo tornase a fechadura controlada pelas mais variadas formas de ritualização e cerimônias que impõem

\footnotetext{
${ }^{119}$ Ibidem, p.58.

${ }^{120}$ FOUCAULT, M. Le sujet et le pouvoir. Dits et Écrits IV, №306, 1982, p.236.

${ }^{121}$ FOUCAULT, M. Le pouvoir psychiatrique, p.49.
} 
ao sujeito a distribuição e quotização de suas tarefas e ordenações a se realizar. O mais relevante aqui são as implicação postas numa "coerção ininterrupta, constante, que vela sobre os processos da atividade mais que sobre seu resultado e se exerce de acordo com uma codificação que esquadrinha ao máximo o tempo" ${ }^{122}$, ou seja, que ressalta menos o produto que a forma de produzir, de ativar sobre o corpo e seus gestos um exaustivo controle, de criar uma techné capaz de extrair daí um saber aprimorado, cuja otimização é sempre bem vinda em proveito da própria construção do tempo. É evidente, assim, embora de uma forma acentuadamente embrionária, o quanto a pastoral já representava esta forma de controle. $\mathrm{O}$ que vem à tona no momento histórico das disciplinas, por conseguinte, irá se tornar conditio sine qua non para a efetivação de saberes que se distribuem de maneira assimétrica, pois a regulação se dispositivou nas próprias condições de que o tempo tornou-se capturado em seus efeitos distintos. Daí o fato de o saber, que se desenvolve e tem locus nas escolas, prisões, hospitais, nos asilos, nos hospícios, quartéis, no âmbito geral da própria sociedade disciplinar, apresentar as suas peculiaridades ainda que sejam interligadas pela própria estrutura disciplinar ${ }^{123}$. Seja como for, relacionado ao tempo, não podemos perder de vista que "o poder disciplinar vislumbra o futuro (avenir), o momento onde tudo funcionará por si e onde a vigilância", arte fundamental no controle, "poderá ser apenas virtual, ou a disciplina, por conseqüência, um hábito" ${ }^{124}$. Sob este esquadro, disciplina configura-se como uma força que faz toda linha temporal encontrar consigo mesma, a fim de reproduzir o tempo sobre o seu próprio eixo, sobre a sua própria repetição, numa mesma mecânica. O modo de ser que emerge daí é absolutamente condicionado a toda distribuição elaborada nos procedimentos desta forma de controle.

Mas isto não é tudo. Aliás, o sentido alcançado na produção de um determinado tempo não se dissocia da própria codificação que esquadrinha também o espaço e os movimentos. $\mathrm{O}$ que Foucault designou de "a arte das distribuições" representa muito bem as maneiras pelas quais o poder disciplinar se acerca de diversas técnicas com o propósito de distribuir os indivíduos no espaço sob o aproveitamento de um tempo para que cada um saiba onde é o seu

\footnotetext{
${ }^{122}$ FOUCAULT, M. Vigiar e punir, p.126.

${ }^{123}$ É relevante o comentário de Ewald neste contexto, pelo fato de nos inserir na dimensão concomitante de divergência e convergência da aplicação dos saberes. De um lado, a sociedade disciplinar se espraia ao longo de toda trama de saber aplicado sobre ela, notadamente, via os canais normatizadores; por outro, unifica-se pelo próprio tecido disciplinar. Sendo assim, "o que faz a sociedade disciplinar é, precisamente, que as disciplinas não dividem (cloisonnent). Ao contrário, sua difusão, longe de cindir ou de compartimentar, homogeneíza o espaço social. O importante na idéia da sociedade disciplinar é a idéia de sociedade: as disciplinas fazem sociedade; elas criam um tipo de linguagem comum entre todos os tipos de instituições; elas as tornam traduzíveis umas às outras" (EWALD, F. Michel Foucault et la norme. In. GIARD, L. (Dir.). Michel Foucault: lire l'oeuvre. Grenoble: Editions Jérôme Millon, 1992, p. 205).

${ }^{124}$ FOUCAULT, M. Le pouvoir psychiatrique, p.49.
} 
devido lugar e aí permaneça fixado. Ao afirmar, assim, que a disciplina "organiza um espaço analítico" ${ }^{125}$, é possível enxergar além dos limites, das linhas e fronteiras a especificar as divisões que fecham os indivíduos em um espaço, a relação de funcionalidade que cada um destes espaços passa a ter. O espaço, assim, torna-se uma codificação possível do indivíduo que venha ocupá-lo: ele torna-se uma tática da subjetividade individual. Não à toa, "a tática disciplinar se situa sobre o eixo que liga o singular e o múltiplo". E mais do que isto,

ela permite ao mesmo tempo a caracterização do indivíduo como indivíduo, e a colocação em ordem de uma multiplicidade dada. Ela é a condição primeira para o controle e o uso de um conjunto de elementos distintos: a base para uma microfísica de um poder que poderíamos chamar "celular" $"$.

É esta relação entre o singular e o múltiplo que amarra muito bem os aspectos de cada corpo a ser controlado com relação ao tipo de individualidade produzida. Quer dizer, do trabalho sobre a especificidade de cada corpo, emerge uma pletora de indivíduos, cujas identidades ou aproximações se darão pela função, utilidade e finalidades postas desde os ajustes temporais e espaciais a que foram submetidos.

Para que o ajuste seja, contudo, o mais eficaz possível, o poder disciplinar, forçosamente, vai reestabelecer a regra, isto é, será capaz de "sempre inventar novos sistemas recuperadores", como diz Foucault, atinentes a um "trabalho perpétuo da norma”, pois o que está em jogo é a ativação infinita de uma força que intenta constantemente "recuperar o indivíduo" ${ }^{127}$, fixar a sua função-sujeito, não permitir que ele escape do controle, da finalidade atribuída numa certa ordem, num dado saber, em tal circunstância. Como fundo, sempre há uma espécie de trabalho ortopédico a se realizar sobre ele: ortopedia discursiva, social, institucional, enfim, campos de correções que interditam a perdição deste indivíduo. Nem que para isto ele precise ser punido e retificado ad nauseum, pois toda penalidade, ainda enquanto micropenalidade, "que atravessa todos os pontos e controla todos os instantes das instituições disciplinares", na verdade, da sociedade disciplinar, "compara, diferencia, hierarquiza, homogeneiza, exclui. Em uma palavra, ela normaliza" ${ }^{128}$. No sistema de disciplina, deste

\footnotetext{
${ }^{125}$ FOUCAULT, M. Vigiar e punir, p.131.

${ }^{126}$ Ibidem, p. 136.

${ }^{127}$ FOUCAULT, M. Le pouvoir psychiatrique, p.56.

${ }^{128}$ FOUCAULT, M. Vigiar e punir, p.163. Nem precisaria ser dito que, acerca deste ponto, são válidos todos os aspectos desenvolvidos por nós referentes à norma. Entretanto não poderíamos deixar de lado uma passagem de Foucault desta mesma obra, que sintetiza muito apropriadamente a relação entre poder disciplinar e norma, aliás, cum grano salis: "a atividade de julgar se multiplicará na medida em que se difundir o poder normalizador. Levado pela onipresença dos dispositivos de disciplina, apoiando-se em todas as aparelhagens carcerárias, este poder se tornou uma das funções mais importantes de nossa sociedade. Nele há juízes da normalidade em toda parte. Estamos na sociedade do juiz-professor, do médico-juiz, do educador-juiz, do 'assistente-social'-juiz;
} 
modo, todos são individualizados não porque são únicos, mas porque a norma passa a ser referência de toda ação que dota de sentido um poder anônimo, que garante a reprodução mecânica e ininterrupta do ato: subordinação, docilidade, adestramento, tudo isto vem à tona. $\mathrm{Na}$ anatomia política do corpo, o homem é um ser calculável.

Não obstante, o cenário do poder disciplinar estaria incompleto, se acaso ignorássemos uma das técnicas mais contundentes responsável pelo uso da força nesta perspectiva de uma sujeição tão estrita, ela carrega o ônus, em boa medida, por tornar o poder sem materialidade, diluído, poroso. Esta técnica consiste e apóia-se nas estratégias de vigilância cujo princípio fundamental é a onivisibilidade. Como o poder disciplinar intervém incessantemente "desde o primeiro instante, desde o primeiro gesto, desde o primeiro esboço", não esquecendo de que também tem em sua tendência a capacidade de "intervir antecipadamente, antes do próprio ato se for possível”, então está implicado aí um “jogo de vigilância, de recompensa, de punição, de pressão que são infra-judiciários" ${ }^{129}$. Com efeito, é justamente no âmbito da vigilância que encontraremos a convergência de todos os recursos e técnicas, com o intuito de dar visibilidade, de modo preciso, a toda e qualquer função-sujeito, cujo relevo é um campo em "que tudo é visto o tempo todo" - Panóptico -, onde há "a

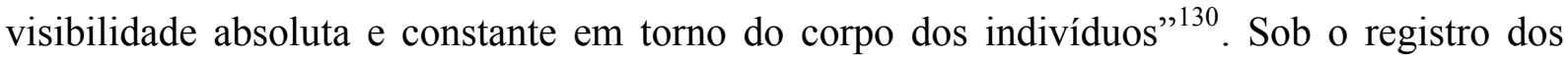
cálculos, é um "diagrama de um mecanismo de poder", como argumenta Foucault, também responsável pela
implantação dos corpos no espaço, de distribuição dos indivíduos em relação mútua, de organização hierárquica, de disposição dos centros e canais de poder, de definição de seus instrumentos e de modos de intervenção, que se podem utilizar nos hospitais, nas oficinas, nas escolas, nas prisões. Assim, cada vez que se tratar de uma multiplicidade de indivíduos a que se deve impor uma tarefa ou um comportamento, o esquema panóptico poderá ser utilizado. ${ }^{131}$

A abrangência concebida aqui não deve nos assustar. De fato, é preciso ter em mente que "nós vivemos num panoptismo generalizado pelo mesmo fato de vivermos no interior de um sistema disciplinar" ${ }^{132}$. Portanto, poderíamos dizer que o panoptismo é um intensificador de forças porque, na mesma dimensão que individualiza pelo jogo de visibilidade, estabelece e acumula um conhecimento sobre o comportamento individual, representando, assim, um saber

\footnotetext{
todos fazem reinar a universalidade do normativo; e cada um no ponto em que se encontra, aí submete o corpo, os gestos, os comportamentos, as condutas, as aptidões, os desempenhos" (opus cit, p.226).

${ }_{129}$ FOUCAULT, M. Le pouvoir psychiatrique, p.53.

${ }^{130}$ Ibidem, p.54.

${ }^{131}$ FOUCAULT, M. Vigiar e punir, p.181.

${ }^{132}$ FOUCAULT, M. Le pouvoir psychiatrique, p.81.
} 
permanente sobre o indivíduo. Não seria, então, desprezível concebermos esta ótica como a sagração final, melhor dizer, o ponto culminante de toda extensa estrutura de forças que transpassa, na mesma proporção que constitui, os sujeitos históricos em suas individualidades. Mesmo porque Foucault nos dá razões de sobra para assim pensarmos, pois “quem está submetido a um campo de visibilidade, e sabe disso, retoma por sua conta as coações do poder; fá-las funcionar espontaneamente sobre si mesmo; inscreve em si a relação de poder e torna-se o princípio de sua própria sujeição" ${ }^{133}$.

Entrementes, como é peculiar à força, inclusive imanente a ela, todo este cenário sofrerá uma transformação profunda e sensível em suas vias de aplicação, acarretando, notadamente em sua distribuição, uma tendência que, a nosso ver, torna-se mais abrangente enquanto uso e prática de forças voltadas para a produção de um novo tipo de sujeito que é o coletivo, orgânico, adstrito a um outro nível que não mais se identifica estritamente com o indivíduo. Na inauguração desta nova démarche, o âmbito do controle perderá a sua especificidade disciplinar, portanto celular, para atingir contornos generalizantes e massificadores. Mais do que nunca, veremos os processos de subjetividade se verticalizar no fundo de um horizonte totalizador que assume não apenas a tarefa de empreender, na prática, técnicas de poder, mas também tecnologias. O Panóptico, por assim dizer, passa a ser acompanhado por um "personagem político absolutamente novo: a população"134. Os dispositivos de poder se avançam para as "instâncias tutelares da espécie"135. O poder torna-se biopoder; a estrutura anátomo-política em biopolítica.

A interpretação que intentaremos forjar para este cenário emergente considerará a formação desta tecnologia de poder como um paroxismo das relações de forças nos processos históricos de constituição das subjetividades, notadamente pelo fato de pôr em relevo as camadas e extensões do âmbito da arte de condução humana que se arrefecem. Talvez, adiantando-nos um pouco, todo tipo de enfrentamento possível existente no eixo e margens do poder se dá precisamente na dinâmica das forças efetivadas para conduzir, não importando a forma, mas sempre estabelecendo um tipo de teleologia subjetiva, contra as forças que pretendem afrontar, escapar, debater, transgredir, romper, modular, refazer, enfim, contra os nódulos das amarras que criam, ligam e saturam os propósitos da vida. Nisto, queremos afirmar que não seria um equívoco conceber o pensamento de Foucault entre análises e

\footnotetext{
${ }^{133}$ FOUCAULT, M. Vigiar e Punir, p. 179.

${ }^{134}$ FOUCAULT, M. Sécurité, territoire, population, p.69.

135 A expressão, embora coadune perfeitamente ao pensamento de Foucault, como veremos, pertence a Klossowski (cf. KLOSSOWSKI, P. Nietzsche e o círculo vicioso. Rio de Janeiro: Pazulin, 2000, p.177).
} 
diagnósticos das forças incontornáveis de nossa constituição e campos de problematização que instigam, criam e afirmam um par-de-là destas forças, uma possibilidade de vida, cuja condução não seja extenuativamente exterior ao sujeito. De uma forma ou de outra, e indiscriminadamente, o fundo é sempre o caráter político envolvido no modo de ser.

Isto se torna tanto mais convincente e seguro o seu autêntico sentido quando seguimos as transformações do nível dos mecanismos, das técnicas para as tecnologias do poder empreendidas já a partir da aula de 17 de março de 1976, a última por sinal, do curso Em defesa da sociedade, quanto no último capítulo de A vontade de saber, também de 1976, seguidos dos cursos de 1977-1978, Sécurité, territoire, population, e de 1978-1979, Naissance de la biopolitique, sem contar o de 1980-1981, Du gouvernement des vivants.

Levando isto em consideração, julgamos que está, precisamente naquela última aula do curso Em defesa da sociedade, uma importante chave de compreensão do movimento que refocaliza a conjugação e operação das forças. Ali, Foucault fartamente argumenta que, embora veja a partir da metade do século XVIII o surgimento de uma nova tecnologia de poder, é completamente possível conceber que esta

tecnologia de poder não exclui a primeira, que não exclui a técnica disciplinar, mas que a embute, que a integra, que a modifica parcialmente e que, sobretudo, vai utilizála implantando-se de certo modo nela, e incrustando-se efetivamente graças a essa técnica disciplinar. Essa nova técnica não suprime a técnica disciplinar simplesmente porque é de outro nível, está noutra escala, tem outra superfície de suporte e é auxiliada por instrumentos totalmente diferentes ${ }^{136}$.

O entrecruzamento inevitável da técnica com a tecnologia, talvez numa peculiar imbricação residente aí, indica o tipo de silagem sobre a qual uma nova variedade de fenômeno de sujeitamento ganha visibilidade e função, maximizando, ao mesmo tempo, as práticas que se deslocam e desdobram-se na confluência de uma nova tomada de poder. De um modo simples, falar doravante em tecnologia de poder é assumir a re-equalização das instâncias e mecanismos do viés disciplinar focado no homem-corpo para a transformação desta dimensão numa vertente homem-espécie. A questão toda se respalda entre a transição de uma força "essencialmente centrípeta", acima de tudo porque funciona sob um tempo-espaço que concentra, fecha, fazendo voltar o seu interior para si mesmo num efeito de circunscrição em pleno limite regulamentar, para uma "força centrífuga", ou seja, cuja tendência é sempre ampliar, integrando-se a novos elementos e circuitos de forças cujas margens são mais fluidas, abrangentes e não tão regulamentares, pois se dão no plano de uma gestão cujo objetivo

${ }^{136}$ FOUCAULT, M. Em defesa da sociedade, p.289. 
central é alcançar “ regulações (régulations) que permitirão as regulações naturais" 137 da vida dos homens. A tecnologia do poder, deste modo, se difere essencialmente das técnicas, pois nela ressalta-se o papel da gestão sob a ótica de uma naturalização de tendências, organizações, distribuições, em que o indivíduo passa a ser abstraído globalmente na esfera de um corpo-população, mas à guisa de sua própria condição como "homem vivo", com relação ao "homem ser vivo", no limite, ao "homem-espécie"138. O importante é ressaltar que, numa metáfora biológica, ou melhor, do saber clínico, o poder passa a gerir tanto a célula quanto o organismo.

Nesta perspectiva, a tecnologia do poder põe em cena um movimento de duplo alcance. De um lado, considera o corpo-espécie, dado e instância bruta natural da vida, totalmente modificado a partir das ações de forças e controle que passam a gravitar no eixo de um campo problemático "traspassado pela mecânica do ser vivo e como suporte de processos biológicos", como aponta Foucault, concernentes à "proliferação, os nascimentos e mortalidade, o nível de saúde, a duração da vida, a longevidade, com todas as condições que podem fazê-los variar". Por certo que em jogo estará uma série de intervenções que assume o papel, além de controlador, de gestor mesmo, quer dizer, de fazer circular um tipo de racionalidade que submete a vida no âmbito não apenas do pragmatismo, mas também da otimização dos recursos e de suas aplicações para a melhor "gestão calculista da vida"139. Maximização, de um lado, de elementos positivos a serem criteriosamente definidos pela estimativa política como algo pertinente à vida e, de outro, minimização constante dos riscos, perdas, inconvenientes e ameaças como, por exemplo, das medidas, não importam quais, que se destinam às doenças, às pestilências, aos roubos, à fome, enfim, ao que causa danos e prejuízos a toda forma de gestão. Estamos perante uma nova forma de cálculo que age peremptoriamente sobre o tenir compte do que pode acontecer, contudo sob as ações estatísticas para garantir, por um instante, "a perfeição da função" que se pretende chegar com a vida ${ }^{140}$.

Não obstante, para assegurar o funcionamento desta nova tomada de poder, precisamos entender a ligação da vida gerida com o aspecto diacrônico da própria conjuntura na qual ela se instala, ou seja, que, nas condições administradas artificial e intencionalmente, a vida passa a se dispor no núcleo de uma população qualquer, fruto de um recorte tornado

\footnotetext{
${ }^{137}$ É de Foucault a diferenciação entre força centrípeta e centrífuga. Cf. Sécurité, territoire, population, p.46. Quanto a esta citação, opus cit, p.361.

${ }^{138}$ FOUCAULT, M. Em defesa da sociedade, p.289.

${ }^{139}$ Acompanhamos aqui a argumentação de FOUCAULT, M. História da sexualidade: a vontade de saber, p.131.

${ }^{140}$ Cf. FOUCAULT, M. Sécurité, territoire, population, p.21 ss.
} 
efeito de medidas adotadas em nome de sua segurança. Entendida como "uma multiplicidade de indivíduos que estão e existem a não ser profundamente, essencialmente, biologicamente ligados à materialidade e ao meio no qual existem" ${ }^{141}$, a população porta uma dupla marca. A das intenções de gestão que estão apoiadas em um novo dispositivo, cujo estandarte soergue um discurso e uma prática em nome da segurança desta população. Quer dizer, atuando na construção de um meio adequado para a sua disposição e distribuição - meio enquanto espaço em que se permite ou interdita determinada circulação -, os dispositivos de segurança irão atuar, "fabricando, organizando, arrumando um meio antes mesmo que a noção tenha sido formada e isolada" ${ }^{142}$, isto é, maximizando um espaço próprio, onde será posto em evidência um determinado tipo de população. Cada meio poderá, assim, interferir com uma série de acontecimentos e especificações que, num jogo de associação e homeóstase política, produz em torno dele a "irrupção da naturalidade do espaço no interior da artificialidade política de uma relação de poder" ${ }^{\text {"143 }}$. Não é sem sentido que para Foucault "o problema político moderno está ligado à população" 144 enquanto sujeito coletivo construído também politicamente. Tendo isto em vista, podemos então apreender o quanto esta tecnologia de poder

se instala, se dirige à multiplicidade dos homens, não na medida em que eles se resumem em corpos, mas na medida em que ela forma, ao contrário, a massa global, afetada por processos de conjunto que são próprios da vida, que são processos como o nascimento, a morte, a produção, a doença, etc., ${ }^{145}$

mas sempre consignados a um tipo de meio produzido artificialmente.

Se é assim, a vida não existe mais para fora dos critérios que são essencialmente as forças de condição exercidas por intermédio do jogo de veridicção que se instala como forma, ou melhor, espécie de regime criterioso imbuído por um "conjunto de regras que permitem, à propósito de um discurso dado, fixar quais são os enunciados que poderão ser caracterizados como verdadeiros ou falsos" ${ }^{146}$. Numa idéia muito simples, a vida entra na dimensão cuja trama condicionante passa a ser os critérios engendrados em toda forma de política de gestão que, desde os critérios notadamente econômicos, de mercado, de ganhos e perdas, enfim, dos "cálculos das relações, cálculos das riquezas, cálculos dos fatores de potência"147, estabeleceram uma nova forma de condução ligada a uma história precisa, rigorosa e

\footnotetext{
${ }^{141}$ FOUCAULT, M. Ibidem, p.23.

142 Ibidem, p.22.

143 Ibidem, p.23.

${ }^{144}$ Ibidem, p.78.

${ }^{145}$ FOUCAULT, M. Em defesa da sociedade, p. 289.

${ }^{146}$ FOUCAULT, M. Naissance de la biopolitique, p.37.

${ }^{147}$ Ibidem, p.315.
} 
articulada sobre uma arte de governar, da qual não podemos escapar, de uma maneira ou de outra.

Todo este cenário, a nosso ver, indicia o estatuto dos princípios e formas, a depender da plasticidade que, como Foucault faz questão de sublinhar, é sempre de um modo muito geral, toca a população por inúmeros processos que assumem os papéis de intenção, controle, remanejamento, proibições, permissões, divisões viridiccionais, enfim, com o intuito de fazer cumprir uma série de "controles reguladores: uma biopolítica da população"148. O que vemos se concretizar neste bojo é a gestão calculista da vida. Nela, o que vem a ser administrado é um "corpo múltiplo, corpo com inúmeras cabeças, se não infinito pelo menos necessariamente numerável" " Daí o destaque e importância da presença de mecanismos políticos que se voltam para as previsões, as estimativas, as medições globais. Não é à toa que Foucault enxergará aí uma chave crucial como condição histórica de cálculos explícitos de um poder tornado biopoder que, como ele sustenta, foi, sem a menor dúvida, o "elemento indispensável ao desenvolvimento do capitalismo, que só pôde ser garantido à custa da inserção controlada dos corpos no aparelho de produção por meio de um ajustamento dos fenômenos de população aos processos econômicos" ${ }^{150}$. Foi necessário, assim, que um determinado tipo de poder investisse sobre a vida, de cima a baixo, para otimizar um estado específico em detrimento de outros.

A esta altura, as formas de regulamentação se diluem no estatuto das formas de gestão que estarão presentes e caracterizarão as distintas maneiras de governamentalidade que se instalam no Ocidente. Neste caso, regular passa a ser, in extremis, a capacidade de exercer o "direito de morte e poder sobre a vida", ou seja, o poder assumindo a função de "intervir para fazer viver, e na maneira de viver, e no 'como' da vida, a partir do momento em que, portanto, o poder intervém sobretudo nesse nível para aumentar a vida, para controlar seus acidentes,

\footnotetext{
${ }^{148}$ FOUCAULT, M. História da sexualidade: a vontade de saber, p.131. Interessante notar o comentário muito preciso de Giorgio Agamben a este respeito. Para este autor, a biopolítica marca "a crescente implicação da vida natural do homem nos mecanismos e nos cálculos do poder" e, por isto mesmo, "em nosso tempo a política se tornou integralmente biopolítica", pois "ela pôde constituir-se em uma proporção antes desconhecida como política totalitária" (AGAMBEN, G. Homo sacer: o poder soberano e a vida nua I. Belo Horizonte: Editora UFMG, 2002, p.125-126). Conceber a biopolítica no horizonte de em uma política totalitária, conforme a nossa interpretação, é situá-la além de qualquer totalitarismo histórico enquanto prática de dominação vigente e exacerbada. No caso, entendemos este ponto como o cúmulo da presença de um poder que, notadamente voltado para a vida, ainda é da ordem da produção, pois, como ainda remarca Agamben, "uma das características essenciais da biopolítica moderna (que chegará, no nosso século [século XX], à exasperação) é a sua necessidade de redefinir continuamente, na vida, o limiar que articula e separa aquilo que está dentro daquilo que está fora" (Ibidem, p.137-138). As questões atuais, deste modo, tocante aos direitos, cidadania, nacionalidade, normalidades e anormalidades, por exemplo, corroboram esta interpretação e ainda ressaltam, por evidência, o tipo de estrutura fundamental que a biopolítica encerra sobre si: "a decisão sobre o valor (ou sobre o desvalor) da vida como tal" (Ibidem, p.144)

${ }^{149}$ FOUCAULT, M. Em defesa da sociedade, p.292.

${ }^{150}$ FOUCAULT, M. História da sexualidade: a vontade de saber, p.132.
} 
suas eventualidades, suas deficiências" $" 151$. Seja como for, tal registro evidencia o aspecto assimétrico que permeia qualificação e desqualificação da vida. É por este caminho, aliás, que a problemática da raça surgirá como nó central na esfera da biopolítica-biopoder. Ora, as questões a ela associadas redimensionam a intenção de equilíbrio global forçado pelo âmbito da gestão da vida, a se apresentar como um dos nós centrais com relação à força que se exerce no âmbito da tecnologia, pois faz valer um tipo de homeóstase justificada pela "segurança do conjunto em relação aos seus perigos internos" ${ }^{152}$, ou seja, traz à lume um tipo de assimilação imposta pelo interesse de uma curvatura normalizante.

Mais uma vez, tal como no poder voltado à série corpo individual-disciplinainstituições, veremos a norma atuando na série corpo coletivo-mecanismos regulamentadoresgestão-Estado, onde se acentua uma espécie de bio-regulamentação pelo Estado, representante cabal na arte da condução humana, que permite, a um só tempo, "controlar a ordem disciplinar do corpo e os acontecimentos aleatórios de uma multiplicidade biológica, de uma população que se quer regulamentar" ${ }^{\prime 153}$. Nesta confluência, a raça se desdobra como um problema de duas vias. Numa primeira instância, o tipo de corte, a cisão incontornável, que o biopoder incumbe de realizar com relação a um domínio preciso da vida: "o corte entre o que deve viver e o que deve morrer”. A raça, neste contexto, é um tipo de fragmentação política operada na vida, quer dizer, uma maneira de "defasar, no interior da população, uns grupos em relação aos outros", no sentido de uma censura biológica respaldada pela conveniência de um domínio ou projeto de condução humana. Assim, a função do racismo torna-se a de "fragmentar, fazer censuras, no interior desse contínuo biológico a que se dirige o biopoder" ${ }^{154}$. Consonante a isto, numa segunda instância, vemos plasmar um papel positivo

\footnotetext{
${ }^{151}$ FOUCAULT, M. Em defesa da sociedade, p.295.

${ }^{152}$ Ibidem, p.297.

${ }_{154}^{153}$ Ibidem, p.302.
}

${ }^{154}$ Acompanhamos a argumentação de FOUCAULT, M. Ibidem, p.305. Esta é a interpretação, a nosso ver, que Agamben dispensa à própria noção de povo. Seguir a sua linha argumentativa é de extrema importância não apenas para o entendimento deste tópico como, não menos importante, o de sua atualização. Para Agamben, “toda interpretação do significado do termo 'povo' deve partir do fato singular de que, nas línguas européias modernas, ele sempre indica também os pobres, os deserdados, os excluídos." Mas, deste modo, "um mesmo termo denomina, assim, tanto o sujeito político constitutivo quanto a classe que, de fato, senão de direito, é excluída da política". Com isto, continua Agamben, "o 'povo' carrega, desde sempre, em si, a fratura biopolítica fundamental. Ele é aquilo que não pode ser incluído no todo do qual faz parte, e não pode pertencer ao conjunto no qual já está desde sempre incluído. Daí as contradições e as aporias às quais ele dá lugar toda vez que é evocado e posto no jogo da cena política". Mas na dotação das engrenagens do biopoder, esta biopolítica pode ter justamente a pretensão de eliminar todo este jogo de fendas por intermédio da regulação da vida gestada na utopia dos cálculos planificadores a forçar uma certa adaptabilidade à normalização que se impõe. "Nesta perspectiva, o nosso tempo nada mais é que a tentativa - implacável e metódica - de preencher a fissura que divide o povo, eliminando radicalmente o povo dos excluídos. Esta tentativa mancomuna, segundo modalidades e horizontes diversos, direita e esquerda, países capitalistas e países socialistas, unidos no projeto - em última análise vão, mas que se realizou parcialmente em todos os países industrializados - de produzir um povo uno e indiviso. A obsessão do desenvolvimento é tão eficaz, em nosso tempo, porque coincide com o projeto 
para o racismo, que privilegiará não mais um indivíduo, mas todo um fundo de espécie fazendo vigorar determinadas condições que têm de ser compatíveis com uma força. Aqui, o exercício do biopoder é inerente ao preço da vida que uns pagam em detrimento das vantagens que outras vidas acumulam. "Se você quer viver, é preciso que o outro morra"; então "viverei, mais forte serei, mais vigoroso serei, mais poderei proliferar", quer dizer, a morte articulada nesta conjuntara se delineia numa especificidade terrificante e, enquanto tal, de uma maneira extremamente nua: "a morte do outro não é simplesmente a minha vida, na medida em que seria minha segurança pessoal; a morte do outro, a morte da raça ruim, da raça inferior (ou do degenerado, ou do anormal), é o que vai deixar a vida em geral mais sadia; mais sadia e pura". Por conseguinte, no âmbito da biopolítica, o poder que se exerce é de uma força adstrita à relação biológica. É o fato de que a vida não está submetida apenas a um risco direto de morte, mas a uma morte indireta, a um tipo de assassínio indireto pelo fato de uns mais que outros estarem expostos à morte, "de multiplicar o risco de morte ou, pura e simplesmente, a morte política, a expulsão, a rejeição, etc”. Ainda na farta argumentação de Foucault se:

esse mecanismo pode atuar é porque os inimigos que se trata de suprimir não são adversários no sentido político do termo; são os perigos, externos ou internos, em relação à população e para a população. Em outras palavras, tirar a vida, o imperativo da morte, só é admissível, no sistema do biopoder, se tende não à vitória sobre os adversários políticos, mas à eliminação do perigo biológico e ao fortalecimento, diretamente ligado a essa eliminação, da própria espécie ou da raça. A raça, o racismo, é a condição de aceitabilidade de tirar a vida numa sociedade de normalização ${ }^{155}$.

Numa idéia final e por conseguinte, o racismo passa a ser a expressão mais viva da presença do biopoder e dos processos que racionalizam a sua aplicabilidade, a biopolítica, como exercício de uma força que se dirige ao direito de causar a vida ou devolver à morte. Enfim, o racismo, como argumenta Foucault,

[...] se forma nesse ponto (racismo em sua forma moderna, estatal, biologizante): toda uma política do povoamento, da família, do casamento, da educação, da hierarquização social, da propriedade, e uma longa série de intervenções permanentes no nível do corpo, das condutas, da saúde, da vida quotidiana, receberam então cor e

biopolítico de produzir um povo sem fratura". Mas não nos esqueçamos de que, para tanto, é justamente o trabalho de corte que se realiza, isto é, as operações que infinitamente procuram purificar o "povo" de todos aqueles velhos empecilhos conhecidos de nós que podem atravancar todo e qualquer tipo de avanço e desenvolvimento. Estão aí para testemunhar as lutas entre o povo da cidade e do campo; o povo do ocidente e o povo árabe; o povo cristão e o povo mulçumano e o povo judeu; o povo do Primeiro Mundo e o povo do Terceiro. O que mantém sempre latente a biopolítica é a sua constante relação com a fissura e a sua tentativa incansável de seu preenchimento. (AGAMBEN, G. Homo sacer: o poder soberano e a vida nua I. Belo Horizonte: Editora UFMG, 2002, p.183, 184, 185 para as respectivas citações realizadas aqui).

${ }^{155}$ Ibidem, p.305-306 para toda citação deste contexto. 
justificação em função da preocupação de proteger a pureza do sangue e fazer triunfar a raça ${ }^{156}$.

Sob este cenário, a vida torna-se não apenas um conceito político, mas também uma perspectiva política. A implicância fundamental aí é toda série de arranjo como forma de intervenção e construção de campos que se dirigem para um tipo de subjetividade - ou simplesmente práticas e experiências de vida - administrada. Em nossa história recente, somos todos margeados por forças que enquadram politicamente, se também não criam, as nossas condutas a uma especificidade controlada que se torna uma população. Com isto, é preciso entender que a biopolítica designará "a maneira pela qual se tentou, desde o século XVIII, racionalizar os problemas propostos à prática governamental, pelos fenômenos próprios a um conjunto de seres vivos constituídos em população" ${ }^{157}$. Assim, ela necessariamente liga-se com uma multiplicidade de tecnologias de governo que perpassa os problemas específicos da vida numa população, fazendo sobrepor a "arte de governar pela verdade, arte de governar pela racionalidade do Estado soberano, arte de governar pela racionalidade dos agentes econômicos, arte de governar pela racionalidade dos próprios governados" ${ }^{158}$. E serão os jogos de forças exercidos por estas distintas artes de governar que focalizarão os problemas específicos de todo modo de ser como objeto de debate, ação e prática de governamentalidade.

Ao longo de toda esta linha e do ponto de vista da história da subjetividade ocidental, o que desejamos deixar claro é que o conjunto de força essencial a se relacionar com a constituição do sujeito não prescinde nem dos processos e técnicas de poder-saber para a individualização nem dos processos e tecnologias de poder-saber para a totalização. De um modo ou de outro, é sempre sob este espectro que o terreno da subjetividade se condicionou, tipo de círculo vicioso cujos repertórios são dispostos como possibilidade de ser, para ser, encaixados numa ordem qualquer: a do saber, a do poder, a da subjetividade articulada politicamente. Toda série tangente ao governo dos homens nada mais é do que o paroxismo da ação da força: a correspondência perfeita de expectativa. Então, "se a governamentalização é realmente o movimento relacionado à sujeição individual na realidade de uma prática social por mecanismos de poder que apelam para a verdade", ou seja, a teleologia disposta no valor de uma condução qualquer, seria o caso de indagarmos se, desta tomada, não é possível a consecução de um outro tipo de força que vislumbraria o confronto de toda a nossa história de

\footnotetext{
${ }^{156}$ FOUCAULT, M. História da sexualidade I: a vontade de saber, p.140.

${ }^{157}$ FOUCAULT, M. Nascimento da biopolítica. In. Resumos dos cursos do Collège de France, p.89.

${ }^{158}$ FOUCAULT, M. Naissance de la biopolitique, p.316.
} 
sujeição. Mas aí é imprescindível a construção de um movimento distinto, que não abre mão de um tipo de sujeito, por assim dizer; movimento, é forçoso ressaltar, a estabelecer justamente a crítica ao sujeito: campo de decomposição tática e estratégica permanente, que afrontará toda linha de condução e de possibilidade de ser administrada. A crítica, de tal modo, "é o movimento para o qual o sujeito dá a si mesmo o direito de questionar a verdade concernente aos efeitos de poder e questionar o poder referente aos discursos de poder". Numa idéia final, a "crítica será a arte da insubmissão voluntária, da reflexão indócil. A função essencial da crítica seria o que, num jogo de dessujeição, poderíamos chamar de política da verdade" ${ }^{159}$. Um novo campo, então, será possível como experiência para o sujeito. Essa experiência tão tênue e tão inesgotável, contudo, mais uma vez se encontrará com a necessidade de um pensamento, cuja expressão de diagnóstico e de experimento não se descentra da própria história crítica do pensamento. Pensar o sujeito é, incontornavelmente, posicionar-se aí: questão de perspectiva inesgotável - alguma coisa é suscetível de se transformar; alguma coisa é suscetível de se dessujeitar. Como, então, ultrapassar as próprias relações de forças dadas em toda esta dimensão? Como é possível romper com as redundâncias dos processos históricos de sujeição? E quais as implicações disto? De que modo o uso e aplicação das forças podem ser engendrados para um governo de si, para a criação de processos de uma subjetividade cuja identificação do sujeito passa a ser a sua própria força?

\subsection{Acontecimento e dessujeição: a constituição do sujeito da ação ou a força produtiva de si}

Marcada essencialmente com a emersão de acontecimentos estranhos a uma sucessão ou continuidade temporal, a descontinuidade ressalta, como dobra, toda nova série de condições de saberes, ordens discursivas, práticas, domínios, instituições, canalização e dispersão de forças, por exemplo, que funciona como linhas margeadoras das experiências humanas em todo campo de finitude. Duas passagens, a nosso ver, representam a própria descontinuidade reencontrada nas sinuosidades da produção de novos acontecimentos tangentes à temática do sujeito. A primeira anuncia: "somos prisioneiros de certas concepções de nós mesmos e de nossa conduta. Devemos mudar nossa subjetividade, nossa relação

\footnotetext{
${ }^{159}$ FOUCAULT, M. What is critique? p.386.
} 
conosco mesmo"; já a passagem seguinte assevera: "sem dúvida, neste instante, o objetivo principal não é o de descobrir, mas o de recusar o que somos. Devemos promover novas formas de subjetividade refutando o tipo de individualidade que nos foi imposta durante vários séculos" $" 160$. Parece-nos que aqui e doravante a fecundidade do pensamento foucaultiano se depara com uma problematização rigorosa, que põe à prova, tanto quanto desafia, a extensão de um diagnóstico histórico que se preocupou em atualizar, cada vez mais adiante, os diversos campos das forças produtoras que, simultaneamente, estão a plasmar pelos mecanismos individualizantes e totalizadores um tipo de subjetividade extensiva a toda ordem de saberpoder-domínios moralizantes presentes, de alto a baixo, em todo corpo social. Como seria possível, então, concebermos uma mudança de subjetividade se dela já somos prisioneiros dado os limites históricos dos quais não podemos saltar? "- não podemos pular para fora deste mundo" 161 . Como estabelecer uma perspectiva de recusa do que somos se o somos desde uma individualidade constituída e firmada na normalização das esferas de poderes englobalizadores, efeitos de população? É possível mesmo, aliás, buscar a afirmação de um tipo de sujeito de coupure, pensemos em força-menor, diante de toda série de força-maior, que vigora e redunda sobre ele enquanto condições históricas incontornáveis, ao alegar o incitamento a uma promoção de novas subjetividades? Ou seja, como romper, como descontinuar se o sujeito já é um ser-aí na história; como refutar o que é imposição? Vis-à-vis a todo uso e aplicação de força na constituição das sujeições, numa idéia, como tornar-se sujeito sem ser sujeitado?

O conjunto destas questões não diz respeito a um impasse ou armadilha constituída no bojo de uma contradição, porém remarca e confirma tanto mais todo viés de Foucault, tanto metodológico quanto teórico, donde, aliás, torna-se perfeitamente possível o lançamento desta nova démarche. Do lado metodológico, o que vemos é novamente a busca do posicionamento de reproblematização quanto à história. Porque não é uma história de solução que se impõe, o fundamental é entender que a constituição de um ponto de problematização está para um trabalho específico do pensamento que não se furta à sua operação fundamental, que é "pressentir o perigo que ameaça em tudo que é habitual, e de tornar problemático tudo que é

\footnotetext{
${ }^{160}$ FOUCAULT, M. Foucault étudie la raison d’État. Dits et Écrits IV, No 280,1980 , p.37-38; Le sujet et le pouvoir. Opus cit, $\mathrm{N}^{\circ} 306,1982$, p. 232.

${ }^{161}$ A referência é de FREUD, S. em O mal-estar na civilização. In. Obras completas. v. XXI. Rio de Janeiro: Imago, p.82. Por sua vez, Freud atribui ao autor C. D. Grabbe, em Hannibal: "Ja, aus der Welt werdem wir nicht fallen. Wir sind einmal darin". [Sim, não pularemos para fora deste mundo. Estamos nele de uma vez por todas]. Conforme nota 2 da parte I de $O$ mal-estar na civilização.
} 
sólido" ${ }^{162}$. E aqui cremos que o trabalho maior de Foucault consistiu em tornar visível as forças atuantes, tão solidificadas, sistematizadas, repetidas e bem administradas para a constituição de nós mesmos, ou seja, na preparação e condução dos destinos individuais e coletivos ora explícita ora sub-repticiamente ligados aos inumeráveis cruzamentos históricos de forças plasmadas em séries de práticas e discursos. Todavia, como o nosso sólido destino é concebido precisamente no tabuleiro das forças, não podendo nos livrar delas porque elas produzem e são imanentes à história, o afrontamento daí torna-se inevitável. Esta armação teórica, por assim dizer, restitui o posicionamento de embate ou guerra continuada pelo viés político inerente a todo âmbito e circulação das relações humanas. Este aspecto teórico central na estrutura do pensamento foucaultiano, e tanto mais por isto, é a engrenagem motriz para a produção de deslocamentos no destino absoluto do sujeito na história ocidental. Em outros termos, deslocamento do sujeito que vem a falar na história, que está nela e que, portanto, pode tentar modificar o seu posicionamento e tratamento num jogo de forças que não fecha as possibilidades de formas de subjetividades, pois são inesgotáveis.

Em todo caso, julgamos que a operação primordial consiste em abandonar a ênfase de como a constituição do sujeito se dá de modo objetivado por séries entrecruzadas de "técnicas de dominação" que, mesmo assentadas sobre uma relação poligonal de diferentes fenômenos, finalizam suas forças sempre de modo objetivo. O sujeito aí é forma e invenção dadas por intermédio de limites externos que funcionam como modelos dominantes de existência e experiência, como possibilidade controlada de atuação e cadeias de sentido traçadas conforme a expectativa objetiva posta sobre ele. As redes de saberes, o jogo da norma, os dispositivos, a realidade da verdade e das veridicções, a dinâmica disciplinar, o biopoder, todas as séries das artes de governar, enfim, representam senão apenas alguns aspectos importantes de diagnóstico, de certas estratégias, de possíveis cenários que armam as condições preponderantes para que tipos de subjetividades sejam definidas desde o instante que o indivíduo não escapa de se tornar um dado objeto.

Mas mesmo que Foucault tenha reconhecido o seu excesso de insistência nas técnicas de dominação em seus estudos ${ }^{163}$, é certo que, a partir da concepção da história crítica do pensamento, tratou, antes de tudo, de interrogar a história e qualquer um de seus objetos no lugar de se deixar conduzir por eles. Neste aspecto, o foco sempre esteve marcado pelas possibilidades de se entender as vias de transformação histórico-culturais sob as quais sempre

\footnotetext{
${ }^{162}$ FOUCAULT, M. À propos de la généalogie de l'éthique: un aperçu du travail en cours. Dits et Écrits IV, No 344, 1984, p.612.

${ }^{163}$ Cf. FOUCAULT, M. Sexualité et solitude. Dits et Écrits IV, No 295, 1981, p.171.
} 
estivemos suscetíveis também de sofrer transformações. Mas, no momento em que nos é permitido ver que é possível ativar certos operadores de transformação de todo jogo de verdade, tanto o nosso lugar (lieu) quanto a nossa ligação (lier) na/com a história, portanto conosco mesmo, refazem-se. Então é possível pensar como, no lugar do sujeito ser objetivado a partir de forças postas para a sua constituição, para a formação de sua subjetividade, ele poderia, ao contrário, tomar o seu próprio ser como transformação constituída a partir de si mesmo, sob o horizonte de outras ligações de forças. Do sujeito constituído pelo Outro ao sujeito constituído pelo $S i$ - sujeito como objeto em construção para si mesmo. No fundo, a transformação histórica torna-se um acontecimento microscópico na ordem de um modo de ser que pretende se contrapor aos níveis de forças já ordenados. Mais uma vez, o desdobramento genealógico se faz ouvir, pois ainda é o corpo a superfície de todos os acontecimentos, contudo ainda a serem provocados, instigados, produzidos, é verdade, por outro tipo de força.

O ponto central para pensarmos nesta direção e mesmo viabilizá-la consiste, conforme nossa interpretação, em um redimensionar da atuação política do sujeito na história, importante dizer, em toda sua relação com os acontecimentos e a atualidade. Mas não na direção de seus aspectos de sucessão imediata, quer dizer, das experiências fechadas e realizadas, estabelecidas e já circunscritas no interior de uma ordem de sentidos, domínios, instâncias, práticas, enfim, das séries de estados discursivos e não-discursivos a funcionar como estruturas repetitivas e homotópicas na consecução de uma subjetividade, cujo término é sempre dominante. A instigante intermitência da história, a sua descontinuidade, autoriza-nos o desencantamento de um mundo onde não há mais transição pacífica: o próprio cotidiano é sempre abrupto. Esta é a condição de fundo para pensarmos que, embora o sujeito sempre falou, trabalhou e viveu a partir de algum lugar - desde as incansáveis referências da ordem de um discurso, da ordem de um poder - é a ele sempre possível uma interferência sobre estes limites. "É preciso sempre o trabalho sobre os nossos limites" 164 , diria Foucault. De fio a pavio os limites traçam-nos, referenciam-nos, fixam-nos, modelam-nos, disciplinam-nos, abstraem-nos, setorizam-nos, estandardizam-nos, controlam nossas potências, ou melhor, as nossas forças. Trabalhar sobre eles redunda, inescapavelmente, num trabalho sobre nós mesmo enquanto sujeitos, pois, além de sermos "constituídos através de práticas de sujeitamento", o que coincide com o dentro dos limites, de outro modo, quando se opera sobre as suas margens, emerge uma "prática de liberação, de liberdade", que consiste basicamente

${ }^{164}$ FOUCAULT, M. Qu'est-ce que les Lumières? Dits et Écrits IV, № 339, 1984, p.578. 
em tomar por atitude a constante indagação dupla: "o que é preciso aceitar ou não aceitar?”; "se não se aceita, o que se pode fazer?"165.

Se pensarmos no âmbito da multiplicidade do uso e aplicação das forças existentes e nas suas infinitas conjugações e rearranjos, constatamos que a ativação do questionamento acerca dos limites torna-se chave complexa de possibilidades de atuação e ação também inesgotáveis, pois a própria dimensão da força nos permite isto:

\begin{abstract}
o exercício do poder é um conjunto de ações sobre ações possíveis: ela opera sobre o campo de possibilidades onde vem se inscrever o comportamento dos sujeitos ativos (agissants): ele incita, induz, desvia, facilita ou torna mais difícil, ele amplia ou limita, ele torna mais ou menos provável; no limite, ele constrange ou impede absolutamente; mas ele é sempre uma maneira de agir sobre um ou sobre sujeitos ativos, e enquanto eles agem ou são suscetíveis de agir. Uma ação sobre ações. ${ }^{166}$
\end{abstract}

A possibilidade, então, de uma ação sobre outras ações indica uma reversão em nada contemptível no/do fluxo de uma força exercida, pouco importando o seu mecanismo e funcionamento. Deste modo, a posição terminal de um sujeito sob o feixe complexo de forças pode ganhar mobilidade e errância. Entramado como possibilidade de ação, então, o seu envolvimento com as experiências nas quais está suscetível de se defrontar sofre um golpe decisivo que se dá no âmbito da instalação inicial de um ponto de obstáculo haurido da própria condição do poder, de seus espaços, intervalos, desconexões, fissuras, limites - é quando se instala o inesperado, o inclassificável, o irredutível, o divergente, o imponderável, o desvio na linha-limite.

Devemos ressaltar, entretanto, a profunda dependência existente entre o efetivar da ação e a sua real correlação com certos processos criativos. Por sua vez, é preciso pensá-los à guisa de certos envolvimentos, de um lado, e de determinados desenvolvimentos potenciais, de outro. Isto significa o seguinte: se a subjetivação é "o processo pelo qual se obtém a constituição de um sujeito, mais exatamente de uma subjetividade" ${ }^{\text {167 }}$, é justamente na idéia de processo que encontraremos o estatuto provisório de todo sujeito. Quer seja no registro das forças cuja finalização é a subsunção e sujeição; quer seja no registro das forças cuja finalização é a dessujeição, o processo é carente de uma criação que representa sempre um vir-a-ser, pois o sujeito ou não pode deixar de sofrer as incidências de forças que se voltam para ele a fim de finalizá-lo ou não pode deixar de tentar afrontá-las com o intuito de criar outro processo de subjetivação. Então é imperativo que a criação seja sempre a potência

${ }^{165}$ FOUCAULT, M. L'ethique du souci de soi comme pratique de la liberté. Dits et Écrits IV, No 356, 1984, p.733.

${ }_{166}$ FOUCAULT, M. Le sujet et le pouvoir. Dits et Écrits IV, No306, 1982, p.237.

${ }^{167}$ FOUCAULT, M. Le retour de la morale. Dits et Écrits IV, No354, 1984, p.706. 
infinita a materializar-se em ações que não se podem fechar nem na estabilidade nem na continuidade de uma força, a fim de não perder o seu caráter inovador em um processo. A criação é um constante macular no sujeito constituído para desconstituí-lo e novamente abrir outra constituição, não de reposição, mas de efetivação, cuja potência é elevada ao infinito; abertura plena para novas experiências: sujeito em ontogênese vinda-a-ser. "A dessubjetivação, a desnormalização, a despsicologização implicam necessariamente a destruição do indivíduo como tal". Como ele é término das experiências disciplinares, por exemplo, é fazendo “o poder disciplinar malograr: produzindo aquilo que ele não pode classificar - o inclassificável"168 como point d'achoppement, conforme a idéia de Foucault, que os limites são confrontados e o redesenhar de novas margens numa espécie de geopolítica do sujeito podem emergir. Assim, chegamos à idéia de um sujeito de ação: ele é dependente de toda criação possível de ser elaborada, mas sem estabilidade, antes que sua força seja reabsorvida por outra maior. O sujeito da ação é sempre proto-sujeito; cartografia mutante. É dissímil, pois põe em xeque as suas condições de ser. É resiliente, pois não se dá por acabado, não se perde nas estruturas repetitivas. O sujeito de ação é proto-dissímil-resiliente ${ }^{169}$.

O sentido que pretendemos dar a esta conjuntura vai ao encontro de um aspecto nodal do pensamento tardio de Foucault que, conforme defendemos, pode ser entendido como a linha cervical da constituição do sujeito de ação ou da força produtiva que visa à relação de si para consigo mesmo. Levando em consideração a implicação e presença de estratégias e

\footnotetext{
${ }^{168}$ FOUCAULT, M. Le pouvoir psychiatrique, p.55 e 58.

${ }^{169}$ A perspectiva da subjetivação inserta no contexto de sua própria criação é uma discussão rica e ampla que não apenas faz sentido ao pensamento de Foucault, mas que pode ser vista sob certa influência marcante na perspectiva filosófica que, além de nos levar a pensar acerca de "quais processos o indivíduo coloca em obra a fim de se apropriar ou de sua própria relação a si?" (cf. REVEL, J. Le vocabulaire de Foucault. Opus cit, p.61), permite-nos ver que a "subjetivação consiste na invenção de novas possibilidades de vida, na constituição de verdadeiros estilos de vida: um vitalismo sobre fundo estético" (cf. DELEUZE, G. Conversações. Opus cit, p.114.) Contudo, como argumentamos, a medida pela qual o sujeito chega a uma relação consigo mesmo ou em uma subjetivação ativa, um vitalismo sobre si mesmo, depende de uma criação aberta fundada em operações cuja potência é sempre infinita: obra sempre incompleta; ponto difuso no mosaico. Duas abordagens, ambas influentes no pensamento de Foucault, ajudam-nos a reforçar este ponto. A primeira, uma indagação de Canguilhem: "Na medida em que seres vivos se afastam do tipo específico, serão eles anormais que estão colocando em perigo a forma específica, ou serão inventores a caminho de novas formas?" (cf. CANGUILHEM, G. O normal e o patológico. Opus cit, p.100.). A segunda, uma afirmação de Klossowski: "no campo experimental, criar é violentar aquilo que existe, logo, violentar também a integridade dos seres. Toda criação de um novo tipo deve procurar um estado de insegurança; a criação deixa de ser um jogo à margem da realidade; $\mathrm{o}$ criador, a partir de então, não mais reproduz mas produz, ele mesmo, o real" (cf. KLOSSOWSKI, P. Nietzsche e o círculo vicioso. Rio de Janeiro: Pazulin, 2000, p.151). Que a criação de novas formas e a própria criação se vinculam à ordem da transgressão, do próprio questionamento e do repensar o que se é possível fazer conosco mesmo é algo que a empresa foucaultiana não se furta. Seja como for, o sentido de tudo isto ocorre no âmbito de um jogo de desestabilização de forças, como cremos nós. Ou como bem indicou Guattari, "esta tensão não é de nenhuma maneira congelada, catatônica ou abstrata [...], mas animada de um criacionismo mutante, sempre em processo de reinventar-se e também sempre a um passo de perder-se" (cf. GUATTARI, F. O novo paradigma estético. In. SHNITMAN, D. F. (Org.) Novos paradigmas, cultura e subjetividade. Porto Alegre: Artmed, 1996, p.131).
} 
táticas na composição desta temática, entendemos que é pelo viés da análise da problematização do governo de si que uma ferramenta importante vem à tona na direção da criação de uma nova perspectiva política para o sujeito. Isto porque pensamos tratar-se do posicionamento do sujeito para si mesmo enquanto objetivação transcorrida sob o domínio que ele exerce sobre si, como invenção de novas possibilidades de ser. Neste horizonte, não apenas as linhas de afrontamento devem ser definidas e plasmadas, como ainda mais os tipos de forças necessários para tomar o seu próprio modo de ser como autorealização implicada nas opções forjadas de como se posicionar diante de todas as escolhas de finitudes. Desta maneira, cremos que o governo de si é uma espécie de campo organizador, gerador e operacional do modo de ser do sujeito que toma a si mesmo como tarefa a ser realizada. Numa questão geradora, poderíamos dizer que o governo de si atrai para seu campo, ao mesmo tempo que pressupõe e ativa o sujeito de ação, pois em jogo passam a estar todos os aspectos de forças engendrados, a fim de serem utilizados e aplicados para a condução do sujeito, isto é, para distanciá-lo de um modo de ser refratário às malhas dos dispositivos implicados em toda questão do poder.

Levando em consideração que as análises de Foucault relativas à governamentalidade indicam muito bem o vértice e acúmulo das configurações das forças acerca deste ponto, é fundamental, então, partirmos, a fim de darmos consecução e ensejo tanto às características quanto aos efeitos do governo de si, da relação expressamente inequívoca existente entre o si como objeto de constituição do próprio sujeito e a dimensão política envolvida aí, donde, mais uma vez, nos depararemos com a especificidade da política do ser e do ser na política. Notemos, para bem do argumento, a substanciosa colocação de Foucault:

se considerarmos a questão do poder, do poder político, situando-a na questão mais geral da governamentalidade - entendida a governamentalidade como um campo estratégico de relações de poder, no sentido mais amplo do termo, e não meramente político, entendida pois como um campo estratégico de relações de poder no que elas têm de móvel, transformável, reversível - , então, a reflexão sobre a noção de governamentalidade, penso eu, não pode deixar de passar, teórica e praticamente, pelo âmbito de um sujeito que seria definido pela relação de si para consigo mesmo. ${ }^{170}$

Embora, no contexto desta passagem, seja a ética o destaque para a relação de si para consigo mesmo, julgamos ser ela um composto específico, dentre outros, como veremos, arranjados ou dispostos na amplitude maior, cuja expressão mais singular é o governo de si. Sob esta chave de leitura, então, somos autorizados a pensar em quais esforços o sujeito pode hoje

${ }^{170}$ FOUCAULT, M. A hermenêutica do sujeito, p.306. 
fazer para tomar o seu si mesmo, na verdade, criá-lo, constituí-lo, produzi-lo sob o agir voltado para as suas condições e experiências, enfim, como campo estratégico de relações de poder em mobilidade, transformação e, por que não dizer, reversão de forças no feixe da governamentalidade.

Nesta conjuntura, a nossa análise é no sentido de sustentar que o si relacionado aí não é uma forma reflexionante já dada para o sujeito ou sobreposta a ele. Com tanto maior vigor, aliás, sobressai para a sua concepção uma longa e complexa trajetória derivada de processos exclusivamente históricos que se modificam insistentemente. Por intermédio deles, o que está em questão "são as formas e as modalidades da relação consigo através das quais o indivíduo se constitui e se reconhece como sujeito" ${ }^{171}$. As formas desta constituição e reconhecimento, ao que nos parece, são totalmente dependentes do posicionamento que o sujeito passa a ocupar, todavia, sob o registro de uma ação: o si aqui é apenas reconhecido numa certa relação como o governo de si enquanto formação de uma força criativa enquanto estratégia de saída às forças que se impõem e articulam-se. Tal formulação, contudo, está imbricada com toda série de demanda articulada no que Foucault denominou de "cultura de si", que pode ser entendida, conforme nosso especial interesse aqui, por todo tipo de "intensificação da relação consigo pela qual o sujeito se constitui enquanto sujeito de seus atos" ${ }^{172}$. A nosso ver, há aí um chamado para uma tarefa politicamente indispensável, pois é outro posicionamento que passa a ser demandado ao sujeito que, por seu turno, estará intimamente ligado com a perspectiva de que "não há outro ponto, primeiro e último, de resistência ao poder político

\footnotetext{
${ }^{171}$ FOUCAULT, M. História da sexualidade II: o uso dos prazeres, p.11.

${ }^{172}$ FOUCAULT, M. História da sexualidade III: o cuidado de si, p.47. Aqui precisamos assinalar que buscamos na noção-operadora da cultura de si não o seu entendimento exaustivo e meticuloso disposta na obra de Foucault desde suas análises da cultura grego-romana. Tal empresa mereceria, por si só, uma outra linha de pesquisa, o que, de fato, não descartamos. Ao trazer a questão da cultura de si, porém, pretendemos nos dispor na mesma perspectiva que encontramos na tarefa foucaultiana quando pretende atualizar um campo de problematização para "compreender de que maneira o indivíduo moderno podia fazer a experiência dele mesmo enquanto sujeito [...]" (cf. História da sexualidade II: o uso dos prazeres, p.11). Ou seja, a cultura de si nos auxilia a pensar o terreno de atualização de uma problemática desafiadora: como podemos nos tornar sujeitos de nossos atos? Dado o pressuposto do labeur infini exigente para tanto, como insistentemente temos demonstrado, julgamos injusta a tentativa de Hadot ao ponderar que "no lugar de 'cultura de si', seria preferível [a Foucault] falar de transformação, de transfiguração, de 'superação de si' (dépassement de soi)" (HADOT, P. Un dialogue interrompu avec Michel Foucault - convergences et divergences. In. Exercices spirituels et philosophie antique. Paris: Albin Michel, 2002, p.308). Não é apenas o alcance bastante geral que a cultura de si resguarda que está em jogo, mas a recepção e desdobramento atinentes a este enfoque que, ao que nos parece, pelo fato de pôr em cena o debate do cuidado de si, das técnicas de si, do ocupar-se consigo mesmo, da arte de viver, uma série de aspectos atinentes ao governo de si, Foucault pôs à mostra justamente os modos de transformação, transfiguração e superação de si possíveis numa dada cultura. Pensar estes aspectos não é buscar uma solução de reposição, algo rechaçado pelo filósofo; mas problematizar em nossa própria época as condições existentes para emergirmos uma cultura que pudesse privilegiar a experiência de vida como exercício para si e não como domínio de condução, submissão, em que a subjetividade já é arranjada. Mas nem por isto poderíamos pensar, como ainda o fez Hadot, que Foucault tem "a pretensão de propor soluções gerais e definitivas aos problemas filosóficos de nosso tempo" (cf. Opus cit, p.311).
} 
senão na relação de si para consigo" ${ }^{173}$. Então, o si não antecede o sujeito, entretanto, indicia um tipo de modalidade, na verdade um modo de ser, pondo em circulação e relevo tipos de relações e ações que precisam ser evocadas para a efetivação desta modalidade, isto é, da insistência permanente de si como objeto em processo de existir apenas em detrimento de sua própria condução, de seu governo de si. No limite, a emergência do si diz respeito a toda forma de singularidade irredutível e ainda residual, pois parte do solo histórico de cujo pertencimento não escapa: o si é uma insistência e não uma instância ${ }^{174}$.

Destarte, esta abordagem, desde o início, traz em seu bojo a correlação dos temas cuja finalidade e incidência recaem no trabalho de transformação exigente à consecução desta modalidade de sujeito. Ao indagar acerca do "que fazer de si mesmo? Que trabalho operar sobre si? Como 'se governar', exercendo ações onde se é o objetivo dessas ações, o domínio em que elas se aplicam, o instrumento ao qual podem recorrer e o sujeito que age?"175, Foucault, além de nos levar a pensar o estatuto do sujeito por evocar o exercício de crítica permanente interposta entre as condições vigentes e as vindouras de produção de subjetividade, incita-nos a um importante movimento, que vai na direção de delineamentos práticos que fundamentem e possibilitem a chegada a este sujeito que age e cria ações para si mesmo: que trabalho operar sobre si? Em torno disto, parece-nos que dois movimentos se firmam e precisam ser analisados de mais perto. De um lado, algo que poderíamos designar de trabalho crítico; de outro, a série experimental ou prática atinente às operações necessárias para o exercício de um governo de si. Mas, seja como for, julgamos ser impossível a viabilização de qualquer tipo de transformação na produção de subjetividade se não partirmos da forma de enfrentamento mais fundamental a ser estabelecida diante dos pontos de forças conjugados para absorver a singularidade enquanto ponto de resistência. Para impor limite aos limites, temos de nos haver com o modo precípuo de resistência ao uso e aplicação de forças consolidadas de modo capital na abrangência dos empreendimentos de condução presentes na biopolitização da existência e em seu espelhamento encontrado nas combinações do biopoder. Mas por quê? Porque este viés representa a extensão mais regular, atual e reinstalada na produção de efeitos de realidade, cuja essência intransponível diz respeito às artes de conduzir o homem, ou seja, de se portar no diâmetro oposto dos interesses da temática do governo de si. Eis, aí então, o campo da crítica como produção de acontecimento de resistência e

\footnotetext{
${ }^{173}$ FOUCAULT, M. A hermenêutica do sujeito, p.306.

${ }^{174}$ Devemos esta última idéia a POTTE-BONNEVILLE, M. Michel Foucault: l'inquiétude de l'histoire. Paris: PUF, 2004, p.11.

${ }^{175}$ FOUCAULT, M. Subjectivité et vérité. In. Dits et Écrits IV, № 304, 1981, p.213.
} 
transformação urgentes. Que tipo de entendimento, contudo, trazemos a lume quando mencionamos o papel da crítica? Aliás, o que seria, neste registro, a crítica?

A crítica é um instrumento aplicado como agente de transformação porque toda transformação, segundo Foucault, não prescinde da crítica: "o trabalho de transformação profunda não se faz senão em ar livre e sempre agitado de uma crítica permanente" ${ }^{176}$. Sempre voltada para a problematização que não subtrai da atualidade a sua importância maior, deve ser vista como um "modo de ação que é capaz de exercer no interior de certa atualidade", quer dizer, ao indagar o presente como experiência de séries de acontecimentos na proporção que demanda pelo sentido "desta atualidade", o faz com o desígnio de se pensar o que fazer quando falamos em atualidade. É para não nos furtarmos à responsabilidade individual em que "cada um é responsável de uma certa maneira por este processo de conjunto"177, que a crítica deve ser apreendida como instrumento, é claro, visando ao "sujeito da ação - da ação através da qual o real é transformado" ${ }^{178}$. Posto isto e de modo inicial, podemos assinalar com uma citação bastante sólida que

a crítica não deve ser a premissa de um raciocínio que se concluiria por: eis aqui, portanto, o que lhes resta fazer. Ela deve ser um instrumento para aqueles que lutam, resistem e não querem mais as coisas como estão. Ela deve ser utilizada nos processos de conflitos, de enfrentamentos, de tentativas de recusa. Ela não tem de impor a lei à lei. Ela não é uma etapa em uma programação. Ela é um desafio em relação ao que $\mathrm{e}^{179}$.

Autorizados, então, a tomarmos a crítica como um instrumento de luta, resistência e, sobretudo, de não conformidade com o assentamento da realidade, torna-se explícita a incontornável ligação de tais intentos com uma força que necessariamente se põe em conflito, na posição de enfrentamento. Neste caso e mesmo para nos forçar a pensar no seu "desafio em relação ao que é”, estruturamos a crítica em três frentes essenciais: como a arte de não ser governado ou conduzido, o que presume sempre, em maior ou menor escala, o jogo de sujeição; a insubmissão voluntária e reflexão indócil e, finalmente, a crítica como atitude na criação de processos de dessujeição, que nos leva a sustentar que este campo está estritamente ligado com o experimentalismo de Foucault, sendo o governo de si o seu aspecto paroxístico.

Sob este cenário, a crítica exercerá uma função interventora de limite diante dos excessos de governo e condução que atingem amplas esferas da existência, da vida abstraída

\footnotetext{
${ }^{176}$ FOUCAULT, M. Est-il donc important de penser? In. Dits et Écrits IV, № 296, 1981, p.181.

${ }^{177}$ Aqui acompanhamos a argumentação de Foucault respectivamente em Qu'est-ce que les Lumières? In. Dits et Écrits IV, $\mathrm{N}^{\circ} 351,1984$, p.681 e $\mathrm{N}^{\circ} 339,198$, p.568.

${ }^{178}$ FOUCAULT, M. Table ronde du 20 mai 1978. In. Dits et Écrits IV, $\mathrm{N}^{\circ} 278$, p.32.

${ }^{179}$ Ibidem, Id.
} 
nos processos massificadores que passam a ser contabilizados, administrados e calculados no formato de população, que é a prospecção mais profunda do poder sujeitador. O que acontece toda vez que obedecemos? O que é ativado? O que está em jogo? Diante disto, a crítica, para Foucault, "será um meio para um futuro ou uma verdade que ela não saberá e que não será, ela é um olhar sobre um domínio no qual ela quer apresentar limites, no qual ela não é capaz de se tornar a lei" 180 . Parece-nos que o que está em aposta é a tentativa de se buscar transformar as relações possíveis que estão estabelecidas numa perspectiva de poder, pois a crítica torna-se um meio para um futuro, ou seja, dirige-se a um vir-a-ser. Há nela um jogo de forças que pretende transgredir o presente, o estabilizado e estabelecido no tempo, pois, se sofremos a ação de um tipo de governo no presente, e não há como negá-lo, ainda não o fomos na totalidade dos acontecimentos que ainda estão por vir, que estão em construção. Como não ser, então, governado em um futuro na mesma perspectiva que somos neste presente? A indagação é característica própria deste âmbito da força crítica, o que significa dilatar uma espécie de contra-força negativa: “como não ser governado como isto, por isto, em nome destes princípios, nas perspectivas de tais objetivos e por meio de tais métodos, não como isto, não por isto, não por eles",181.

\footnotetext{
${ }^{180}$ FOUCAULT, M. What is critique?, p.383.

${ }^{181}$ Ibidem, p.384. Não podemos nos furtar de indicar que a especificidade de toda esta concepção acompanha o importante diálogo que Foucault estabeleceu com a questão da Aufklärung kantiana. Segundo Foucault, com a publicação-acontecimento de Kant, Beantwortung der Frage: Was ist Aufklärung?, temos a inauguração de um novo modo de interrogação, pois é o presente, a atualidade, o hoje, o que se passa agora que se torna objeto de análise para se criar condições de um "modo de ação" sobre esta atualidade (cf. Qu'est-ce que les Lumières? In. Dits et Écrits IV, No 339,1984 , p. 562-567). Assim, a Aufklärung implicaria necessariamente numa coragem, numa audácia de saber (Aude sapere) o que se passa e o que deve ser feito com o que se passa. No limite, somos incitados a procurar e provocar todo tipo de saída (Ausgang) da condição que, apesar de situada em 1784, ainda continua a exercer o seu domínio sobre o homem nos aspectos da arte de condução. Na interpretação de Foucault, Kant queria lutar contra a menoridade, ou seja, contra "um certo estado de nossa vontade que nos faz aceitar a autoridade de um outro para nos conduzir nos domínios em que convém usar a razão. Kant dá três exemplos:" - ainda segundo Foucault - "estamos no estado de menoridade quando um livro toma o lugar do entendimento, quando um orientador espiritual toma o lugar da consciência, quando um médico decide em nosso lugar a nossa dieta [...] Em todo caso, a Aufklärung é definida pela modificação da relação preexistente entre a vontade, a autoridade e o uso da razão" (Ibidem, p.564). Este jogo é definido pela modificação do foco na recusa de ser governado: que tipo de diferença o nosso hoje pode introduzir para o futuro, sem a pretensão de concebêlo em acabamento; que tipo de diferença o nosso hoje pode introduzir em relação ao passado? Um pouco neste propósito, encontra-se o comentário de Fimiani, para quem "a interrogação sobre o presente, sobre a Aufklärung, nos incita a indicar a diferença radical, o corte no tempo, porque a filosofia das Luzes é, antes de tudo, para a Beantwortung, um Ausgang, uma 'saída' e uma orientação moral, ela é 'um processo que nos livra do estado de menoridade' pela vontade pessoal de pensar, pela decisão de não se deixar conduzir, se não for por sua própria reflexão" (FIMIANI, M. Foucault et Kant: critique, clinique e éthique. Paris: L'Harmattan, 1998, p.21). Mas apesar disto, julgamos que Butler tenha sido mais contundente ao sustentar que "o que Foucault procura na sua descrição das Luzes é precisamente o que resta 'impensado' na sua terminologia: justamente porque a sua história é uma história crítica”. (BUTLER, J. Qu'est-ce que la critique? Essai sur la vertu selon Foucault. In.GRANJON, M-C. (Org.) Penser avec Michel Foucault: théorie critique et pratiques politiques. Paris: Karthala, 2005, p.86). Este impensado traz à tona o reposicionamento de toda visibilidade das experiências, do pensamento e posicionamento do sujeito em face da história, do Outro e de si mesmo. Não é à toa que o tema da atualidade torna-se recorrente na Aufklärung à Foucault. E, neste ponto, faz muito sentido pensarmos como
} 
É evidente, todavia, que a crítica não visa a uma oposição total e generalizada, um tipo de revolta abstrata contra toda forma de governamentalização, que consiste no efeito da multiplicidade das artes de governar; mesmo porque Foucault se distancia de toda tentativa de universalização de um processo de consciência política ou de totalização histórica. É mais na direção de uma oposição contrapontual, marcada pela força microparticular do indivíduo ou de um grupo-singular que se esforça para se despregar da abstração populacional, cada um à sua maneira de mudar, já que nada é mais arrogante do que querer fazer a lei para os outros ${ }^{182}$, que temos de pensar. É neste horizonte que a questão se coloca, enquanto a arte de não ser muito governado, de não querer isto. Atentemo-nos aos termos de Foucault:

contra isto, como contraponto, ou em vez de parceiro ou adversário das artes de governo, como modo de suspeitar delas, de mudá-las, limitá-las, de encontrar suas medidas certas, de transformá-las, de procurar escapar destas artes de governar ou, de qualquer modo, deslocá-las, com uma relutância essencial, mas também ao modo de uma linha de desenvolvimento das artes de governar [...] que eu simplesmente chamaria de a arte de não ser governado, ou a arte de não ser governado com isto, a este preço $^{183}$.

Esta tomada, ao que nos parece, pode muito bem coadunar-se com as possibilidades de "série de contra-condutas", como Foucault expõe em Sécurité, territoire, population. No limite, elas representam a ruptura de todos os laços de obediência, notadamente no aspecto de se "recusar a razão do Estado e as exigências fundamentais desta razão de Estado"184. Enxergar, então, a arte de não ser governado como ênfase numa determinada contra-conduta pode tornar-se o ponto de ancoragem fundamental para uma crítica que, ao indagar pelos

Ewald: "O que formula o problema da atualidade é que a atualidade é em seu sentido, a partir do momento onde se pode fazer esta identificação do presente, a posição ao mesmo tempo de um ato que é suscetível de romper com o presente. É algo de fundamental, muito presente em Foucault: o presente é o que deve ser interrompido. Dividir o presente é fazer que haja um passado e um futuro, donde a noção mesmo do futuro. O futuro é a maneira em que transformamos em verdade um momento, uma dúvida." (EWALD, F. Foucault et l'actualité. In. Au risque de Foucault. Paris: Supplémentaires, 1997, p.205). Portanto, que atualidade invoque a pertinência da ação, melhor, do sujeito de ação como combate à repetição, não nos demora perceber em toda esta conjuntura. ${ }^{182}$ Conforme discorre Foucault em Pour une morale de l'inconfort. In. Dits et Écrits III, No 266, 1979, p.783 ss.

${ }^{183}$ FOUCAULT, M. What is critique?, p.384.

${ }^{184}$ FOUCAULT, M. Sécurité, territoire, population, p.363. A título de um melhor balizamento, colocamos a questão assim: "podemos ver que a razão de Estado, no sentido de um governo racional capaz de aumentar a potência do Estado de acordo com ele próprio, passa pela constituição prévia de um certo tipo de saber. $\mathrm{O}$ governo só é possível se a força do Estado for conhecida; assim ela pode ser mantida". Então, as contra-condutas seriam justamente uma possibilidade de minar a potência do Estado. No caso, o percurso que fizemos no tópico anterior não apenas corrobora, digamos, a genealogia de toda esta razão do Estado no Ocidente como também mostra os seus caminhos de efetivação de potência. Não é destituído de sentido, assim, o que Foucault vem a sublinhar: "A racionalidade política se desenvolveu e se impôs ao longo da história das sociedades ocidentais. Inicialmente, ela se enraizou na idéia do poder pastoral, depois, na da razão de Estado. A individualização e a totalização são seus efeitos inevitáveis. A liberação só pode vir do ataque não a um ou outros pontos desses efeitos, mas às próprias raízes da racionalidade política". (Cf. FOUCAULT, M. "Omnes et singulatim": vers une critique de la raison politique. In. Dits et Écrits IV, No 291, 1981, p.153 e 161). 
limites do direito de governar, no caso da biopolítica, de gerir a vida dos indivíduos na dimensão da população, questiona a base da segurança de quem governa. Talvez ainda mais, em face das exigências do governo e da obediência, "se opõe aos direitos universais e irrevogáveis com o qual cada governo - não importando ser, não importando que ele tenha o papel de monarca, magistrado, educador ou pai de família - terá de submeter" ${ }^{185}$ quem é governado.

Não convém esquecer que toda tecnologia de poder, por conseguinte, toda governamentalização, sustenta-se às custas de uma institucionalização de um discurso eficaz, que circula determinadas ordens de saberes e poderes na direção de uma prática que se pretende verdadeira, desde o saber jurídico, no caso da soberania e legitimidade de um poder que governa, até o discurso científico da biologia no eixo vida-população, no caso da biopolítica. Deste modo, a arte de não querer ser governado elabora, enquanto crítica, "uma espécie de empreendimento para dessujeitar os saberes históricos e torná-los livres, isto é, capazes de oposição e luta contra a coerção de um discurso teórico unitário, formal e científico”. Então, o que passa a estar em questão é a ativação das incoerências, das forças coercitivas, dos limites impostos a cada ser, dos jogos de qualificação e desqualificação administrados, da vida gerida e regulada, da verdade aceita de modo natural, como verdade orgânica, enfim, ativação que pretende: "não aceitar como verdade porque uma autoridade nos diz que é verdade" ${ }^{186}$, enfatiza Foucault. Desta maneira, a crítica abre um campo para a dessujeição dos sujeitos, já que todo processo de sujeição se encontra na confluência das ações da verdade no correlacionar de forças instaladas no eixo poder-saber. Portanto a crítica como a arte de não ser governado como isto, nem pelo preço que pagamos, coloca-se como ponto vital na ação de toda resistência às regulamentações que asseguram as mesmas perspectivas da verdade. Eis aí o passo inicial para uma política de dessujeitamento. Como assevera Foucault, “a crítica essencialmente terá, por função, o dessujeitamento no jogo do que poderíamos chamar, numa palavra, a política da verdade" ${ }^{, 187}$.

\footnotetext{
${ }^{185}$ FOUCAULT, M. What is critique?, p.385.

${ }^{186}$ Ibidem, Id. Válido também para a citação anterior.

${ }^{187}$ Ibidem, p.387. Julgamos extremamente relevante a interpretação que Butler dispensa: "a política da verdade pertence às suas relações de poder que circunscrevem antecipadamente o que será ou não será considerado para a verdade que agencia o mundo de maneira regular e regulável e que nos conduz a aceitar como o campo estabelecido do saber. Compreendemos a importância desta questão quando começamos a indagar: o que é considerado como uma pessoa? O que é considerado para a diferença coerente dos sexos? Quem merece o nome de cidadão? Quem são indivíduos em que o mundo tem uma realidade legítima? De maneira subjetiva, indagamos: que posso eu me tornar em um mundo onde as significações e os limites do sujeito são determinados antes para mim? Quais são as normas constritoras quando eu começo a me indagar o que eu poderei me tornar? Aonde chego quando eu começo a me tornar um objeto para o qual não há lugar no regime estabelecido da verdade? Não é precisamente isto que se trata do significado o 'dessujeitamento do sujeito no jogo da política da
} 
Posto isto, não é difícil de entendermos o desdobrar da crítica numa ação afirmativa ou positiva, que fará circular, nos espaços produzidos pelas estratégias de não querer ser governado, momentos de alteração móveis, inaugurando uma nova tensão nas linhas de experiência com a governamentalização. Trata-se, nesta dimensão, não de um engajamento, mas de um campo de experiência que Foucault nomeará de insubmissão voluntária. A própria relação da estrutura disciplinar presente nas profundezas do corpo social a instilar a docilidade nos incita a vermos aqui uma representação de força que, transtrocando as margens históricas e contextuais do eixo da ordem da política, pretende fazer emergir experiências contrárias a de uma servidão voluntária. Talvez esteja nisto a eficácia de uma biopolítica, pois, ao ativar inúmeras forças que contingenciam a vida dos indivíduos, por conseguinte, acaba referenciando a norma como proximidade de comportamento e exemplo: distribui "os vivos em um domínio de valor e utilidade”, donde será necessário que as artes de governo se valham de um poder que, se tem por tarefa se encarregar da vida, "terá necessidade de mecanismos contínuos, reguladores e corretivos" $" 188$. Assim, toda investidura sobre o corpo, a saúde, as maneiras de se alimentar e de morar, as condições de vida, a sexualidade, enfim, todo o espaço da existência tem de ser administrado como se não o fosse de modo racionalizado, quer dizer, como se todo processo fizesse parte de uma verdade absoluta que simplesmente ativa um curso histórico natural.

Mas se a crítica exerce uma insubmissão voluntária, globalmente o ato e processo de governo, outrora vistos como naturais, fragmentam-se, pois não são justificados por nenhuma voluntariedade. Valendo-nos da argumentação de Foucault:

se governamentalização é realmente o movimento relacionado à sujeição individual na realidade de uma prática social por mecanismos de poder que apelam para a verdade, eu direi que a crítica é o movimento para o qual o sujeito dá a si mesmo o direito de questionar a verdade concernente aos efeitos de poder e questionar o poder referente aos discursos de poder. Crítica será a arte da insubmissão voluntária, da reflexão indócil $^{189}$.

É preciso notar que o par insubmissão voluntária e reflexão indócil não visa somente aos processos de condução e administração da vida, evidenciando uma disposição antagônica a qualquer processo de docilização ou domesticação, que tem por base a distribuição de

verdade?" (BUTLER, J. Opus cit, p.91-92) Isto vem muito mais corroborar o ponto de vista aqui sustentado por nós: a política de dessujeitamento deve estar pari passu com a produção de si, cujo vértice se expressa no governo de si. A este propósito, ainda Butler: "a produção de si e o dessujeitamento se produzem simultaneamente quando se aventura em um modo de existência que não é verificado pelo que ele [Foucault] designou de regime de verdade" (Ibidem, p.78).

${ }^{188}$ FOUCAULT, M. História da sexualidade I: a vontade de saber, p.135.

${ }^{189}$ FOUCAULT, M. What is critique?, p.386. 
justificativas próprias em elementos racionais, calculados, quantificados, tecnicamente eficientes. Indo além, a crítica, neste viés, pretende minar as tecnologias de governo, cujas bases arcaicas se dispõem nos poderes de homogeneidade que na história do Ocidente, como demonstramos alhures, inspirou-se, guardadas as proporções, no aspecto pastoral cuja centralidade no uso das tecnologias de governo tinha como finalidade a condução total do homem, de sua consciência aos seus gestos menores. Não há dúvida de que a arte de governar atual, cujo esteio preponderante se avaliza no par biopolítica-biopoder, é devedora deste longo percurso que começou a preparar os corpos individuais para receberem bem disciplinarmente, docilmente, as forças multirefratárias capazes de reunir, submeter, ajustar, obrigar, controlar. Neste horizonte, "a crítica tem, portanto, uma dupla tarefa, aquela de mostrar como o saber e o poder trabalham construindo uma maneira mais ou menos sistemática de agenciar o mundo", de governá-lo também, acrescentaríamos nós, "segundo as próprias "condições de aceitabilidade de um sistema', mas também uma maneira de 'seguir as linhas de ruptura que marcam sua emergência" "190. Ora, será precisamente esta linha de ruptura, interseccionada pela arte de não ser governado, a insubmissão voluntária e a reflexão indócil, que marcará a crítica como uma final função, quer dizer, como prática de resistência por intermédio do que Foucault denominou de atitude crítica.

Ao referir-se "a uma certa maneira de pensar, de falar, como também de agir, e uma certa relação para o que existe, para o que se sabe, se faz, bem como para uma relação social,

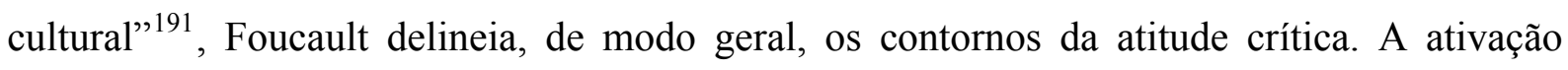
desta atitude diz respeito a um permanente modo de ser histórico que se caracteriza justamente como crítica permanente ao nosso atual modo de ser histórico. Exarada nas problematizações de nossa relação com o presente, a atitude, inexoravelmente, é engendrada e implicada em "um modo de relação que concerne à atualidade; uma escolha voluntária que é feita por alguns; enfim, uma maneira de pensar e de sentir, uma maneira também de agir e de se conduzir que, tudo ao mesmo tempo, marca uma pertinência e se apresenta como uma tarefa" ${ }^{192}$. Defendemos que a posição central que a atitude ocupa na produção da crítica se deve à constituição histórica daquilo que nos tornamos ou somos, que o seu propósito, a não ser perdido o foco, seja "o princípio de uma crítica e de uma crítica permanente de nós mesmos em nossa autonomia" ${ }^{\prime 93}$, quer dizer, como tomada de posicionamento que procura inventar-se a si mesmo: autonomia, portanto, como tarefa, como aquilo que não temos, mas

\footnotetext{
${ }^{190}$ Cf. BUTLER, J. Opus cit, p.94.

${ }^{191}$ FOUCAULT, M. What is critique?, p.382.

${ }^{192}$ FOUCAULT, M. Qu'est-ce que les Lumières? In. Dits et Écrits IV, No 339, p.568.

${ }^{193}$ Ibidem, p.573.
} 
que podemos criar. Esta menção, aliás, permite que a atitude crítica e criação se interliguem como constituição de um campo de forças que atuará como estratégia para não sermos governados totalmente e viabilizarmos, de fato, a reflexão indócil e a insubmissão voluntária como forma de nos relacionarmos com o presente, sem descartar as conseqüências futuras, pois, assim, criticar é criar. Entretanto isto não é tudo. Esta força criativa se desdobra em duas perspectivas que, par e passo, dão azo à atitude crítica. São elas, a atitude-limite e a atitudeexperimental.

Ao redor deste núcleo da crítica, cremos poder encontrar a ignição para fazer trabalhar toda série de inflexão de outras práticas de subjetividade, já que essencialmente a atitudelimite não tratará de rejeitar a vida em suas múltiplas possibilidades ou de se forçar uma escapatória, como alternativa, de um dentro ou fora dos limites estabelecidos. O que ela pretende é abusar das fronteiras; ela mesma se coloca na fronteira do que já é empreendido pelos processos de governamentalização e do que pode vir-a-ser. Quer dizer, a atitude-limite aqui é a postura criativa que forçará a emergência de determinados limites, pois "no que nos é dado como universal, necessário, obrigatório, qual é a parte do que é singular, contingente e que é derivado de coerções arbitrária” que poderá nos levar a outras atitudes em nosso fazer, pensar e dizer? Em termos distintos, e ainda sob a expressão de Foucault, "trata-se em suma de transformar a crítica exercida na forma da limitação necessária em uma crítica prática na forma de uma transposição possível" ${ }^{194}$. Mas se há uma pretensão, por parte da atitude crítica, de se criar uma transposição possível às formas de subjetividade ou condução, ela não poderá abrir mão do componente experimental que associa a própria atitude como contra-força de todo o alvo de regulação, regulamentação e gestão dos aspectos da vida.

É claro que a aposta recai sobre as combinações de número infindo de uso e aplicação de forças a fim de reduzir a vida dos homens em certos campos de experiência: o que se pode ou não fazer, o que se deve ou não fazer com a saúde, a vida, a família, a sexualidade, a morte, a razão, nos servem como exempli gratia. Entretanto, vistos sob o horizonte da atitudeexperimental, estes processos de subjetivação são deslocados na direção de um eixo cujas experiências se colocarão como "prova (épeuvre) da realidade e da atualidade, por sua vez, para empreender os pontos onde a mudança é possível e desejável e para determinar a forma precisa em que ocorrerá esta mudança" ${ }^{195}$. Para tanto, Foucault argumentará que é preciso a elaboração de uma “ontologia histórica de nós mesmos", uma ontologia aberta, diríamos nós, que se radicaliza contra toda determinação e administração do ser. Trata-se de nos desviarmos

\footnotetext{
194 Ibidem, p.574.

${ }^{195}$ Ibidem, Id.
} 
"de todos os projetos que pretendem ser globais e radicais", ou ainda, dos "programas de conjunto de uma sociedade"196. Então, a atitude-experimental preferirá as transformações precisas que podem muito bem ter lugar num certo "número de domínios concernentes ao nosso modo de ser e pensar as relações de autoridade, as relações de sexualidade, o modo pelo qual percebemos a loucura ou a doença" ${ }^{\text {197 }}$. Enfim, tal atitude, enquanto crítica, interroga os limites que nos são colocados e persegue a prova de como os seus ultrapassamentos são possíveis na criação de processos históricos de dessujeição, ou ainda, de deslocamento de subjetividades.

Atentos a esta conjuntura e levando a sua conseqüência ao extremo, nos damos conta de que a própria crítica é um campo do vasto experimentalismo presente no pensamento de Foucault. Os esforços e empreendimentos no sentido de nos livrar de todo destino e rotas já consagradas e engendradas, na tentativa de pensarmos e abordarmos a temática do sujeito de ação, também se encontra neste experimentalismo. É neste registro, sustentamos nós, que devemos recepcionar as análises referentes às multiplicidades temáticas dos posicionamentos do sujeito no recorte histórico-filosófico do universo Greco-romano, elaboradas nas pesquisas dos anos de 1980. Menos, é certo, para medirmos a possibilidade de um vínculo-indentidadepossível de um Foucault estóico, cínico ou helenista e mais para percebermos o quanto o modo de pensar o sujeito pôde ser deslocado de toda centralidade racional e cogitante que, direta ou indiretamente, afastaram-nos de certas modalidades, experiências e possibilidades de tomarmos o ser como campo de problematização em produção constante, sob domínios implicados em toda sorte de atitude e experimento que o sujeito é capaz de provar, provocar, obter, praticar, seja para a constituição, seja para a transformação de si. Campo de outras práticas de subjetividades que não podem ser postuladas sob prescrições, campo que leva em consideração o sujeito como objeto de si e para si mesmo fora dos universalismos que marcaram a trajetória histórico-filosófica do sujeito. O si, tido em seu cuidado de si, implica na tomada que visa "constituir-se como sujeito da ação, capaz de reagir de maneira direta e firme aos acontecimentos do mundo" $" 198$.

\footnotetext{
196 Ibidem, p.575.

${ }^{197}$ Ibidem, id.

${ }^{198}$ Cf. GROS, F . Introduction. In. GROS, F. e LÉVY, C (Orgs.). Foucault et la philosophie antique. Frédéric. Paris: Éditions Kimé, 2003, p.11. Isto tudo está muito bem indicado, por exemplo, a partir da aula de 24 de março de 1982, em sua primeira hora, do curso A hermenêutica do sujeito, quando, após seguir um longo e exaustivo percurso histórico nos Antigos, relendo Aristóteles, Platão, Marco Aurélio, Epiteto e Sêneca, é demonstrado por Foucault que o "conhecimento de si", chave marcante no entendimento do sujeito na história do pensamento ocidental, subordina-se a uma cultura de domínio de si, de dominação ativa sobre si e outros, mas jamais fundada em um sujeito do conhecimento. O sujeito relacionado ao "conheça-te a ti mesmo" emerge por intermédio de um jogo de práticas envolvidas numa série de cuidados, regras que ele faz, por si, a opção de seguir ou não, de aplicar sobre si ou não, seja como for, sempre tendo a finalidade de se governar, de conduzir-se
} 
Por sua vez, a nossa reação aos acontecimentos deste mundo tem o seu sentido senão na produção de acontecimentos disjuntivos de toda ordem. Neste âmbito, a validade de todo experimentalismo não é questionada, mas julgamos poder encontrar no governo de si a forma mais tensionada e criativa de auto-subjetivação pelo fato de pôr em xeque os domínios de condução. Mais do que um encontro com a crítica, esta perspectiva já atestaria a crítica como parte essencial do governo de si. Então, queremos sustentar por esta forma de subjetivação a produção fundamental de um acontecimento enquanto processo de dessujeição, visando ao sujeito da ação e à força produtiva de si mesmo, pelas seguintes razões.

Em primeiro lugar, o governo de si é indissociável de uma cultura de si. Basicamente, as implicâncias aí são de duas ordens. De ordem política, pelo fato de o cuidado de si estar ligado a um exercício de poder, ou seja, ao tipo de força que o sujeito tem de lançar mão para fazer de sua vida uma prova no sentido da experiência e do exercício, isto é, "aquilo a partir do que, através, a despeito ou graças a que iremos nos formar, nos transformar, caminhar em direção a uma meta ou uma salvação, seguir ao encontro de nossa própria perfeição" ${ }^{199}$. As opções atinentes a este campo são forças de abertura contínuas, e por que não dizer, também saídas, em relação às linhas de forças limitantes da própria vida. Em jogo, uma outra economia de força como possível horizonte de uma outra política, quer dizer, de uma distinta forma de tomar o corpo, a existência e as experiências como acontecimentos não programados, fechados, viciosos e contingenciados. É neste horizonte e no limite que ocorre uma mudança fundamental de perspectiva tanto nas partidas quando nas travessias e possíveis chegadas das séries de experiências que são contra-forças ou contra-condutas - "as ilegalidades são o motor das transformações na tecnologia do poder" ${ }^{200}$. Que experiência é possível fazer de si mesmo? A que tipo de força e sob que preço cada um deve se submeter?

Mas a esta perspectiva emerge uma outra que poderíamos chamar de ordem estética. Se o governo de si implica no tomar a si mesmo como objeto, a tomada de consciência da

a si mesmo. Então Foucault diz algo que devemos sublinhar: "A tradição filosófica, no Ocidente em geral, sempre privilegiou o gnôthi seautón, o conhecimento de si, como o fio condutor de todas as análises sobre os problemas do sujeito, da reflexividade, do conhecimento de si, etc [...] espécie de desenvolvimento contínuo do conhecimento de si". Mas, "no interior da própria história do cuidado de si, o gnôthi seautón não tem a mesma forma nem a mesma função. A conseqüência é que os conteúdos de conhecimento que o gnôthi seautón propicia ou libera não serão sempre os mesmos. Isto significa que as próprias formas do conhecimento que são praticadas não são as mesmas. O que significa também que o próprio sujeito, tal como é constituído pela forma de reflexividade, corresponde a um ou outro tipo de cuidado de si , irá se modificar. Por conseguinte, não se deve constituir uma história contínua do gnôthi seautón, que teria por postulado, implícito ou explícito, uma teoria geral e universal do sujeito, mas deve-se começar, a meu ver, por uma analítica das formas da reflexividade, na medida em que são elas que constituem o sujeito como tal" (FOUCAULT, M. A hermenêutica do sujeito, p. 560.).

${ }^{199}$ FOUCAULT, M. A hermenêutica do sujeito, p.590.

${ }^{200}$ Cf. EWALD, F. Anatomie et corps politique. In. Critique. Paris: Minuit, Dez. 1975, Tomo XXXI, No 343, p. 1252 . 
presença de uma força que delineia e constitui a experiência de ser, totalmente aberta possibilidades nas finitudes - aí devemos notar a heteroplasticidade do si, pois a sua variação se dispõe na finalidade mutante de cada possibilidade em experiência. Quer dizer, do mesmo modo que "existe diferentes formas de cuidado", diferentes formas de se conduzir, pois é justamente o jogo de potência infinita que está em cena como transformações do uso e aplicações de forças já engendrados, também deve existir "diferentes formas de si" "201. O sujeito, terminação nominal, deve plasmar a sua forma que não é sempre idêntica a ela mesma, uma vez que as suas relações com as forças são mutantes, algumas mais passageiras, outras decididamente mais permanentes, outras imanentes ao desejo, todavia sempre congruentes a um tipo de ação. Podemos dizer que reside aí o sentido da expressão "fazer de nós mesmos uma obra de arte" ${ }^{202}$. Empreendimento subsumido a uma elaboração de uma estilização da vida que não se perde nem no individualismo arregimentado nos processos de disciplinarização nem no motor da abstração das políticas biopolitizantes. A questão nos impele sempre para um transformar-se, um "modificar-se em seu ser singular e fazer de sua vida uma obra que seja portadora de certos valores estéticos e responda a certos critérios de estilo", numa idéia, "diferentes maneiras de se conduzir, agir"203, acrescentaríamos nós, de desejar, criar, de forjar experiências de alargamento do horizonte e aprofundamento de sentido. No limite, aqui o sujeito opera uma inversão importante: criar e exercer um tipo de força que sirva como instrumento - um abridor de horizontes - para suas escolhas no modo de ser em um mundo, cujos horizontes já foram escolhidos para ele.

Irmos além disto, apesar de tentador, é claro, já não seria coerente com uma produção de si que em nada tem a ver com um desenvolvimento de cunho preceptor ou propedêutico; menos ainda com algum tipo de debate que pudesse sugerir soluções e encaminhamentos. Com efeito, a nosso ver, a angústia da derrelição, neste sentido, deve permanecer latente como força motriz de todo experimentalismo em que o sujeito é capaz de efetivar enquanto visibilidade fugaz de um espaço sempre inocupável e sem totalidade. Se há uma ação, para tanto, ela se centra em jogos de possibilidades, cuja vitalidade é sempre transbordante em sua configuração de força. Atualizar sempre o governo de si, deste modo, é ter por finalidade a submissão do real situado nas dobradiças dos acontecimentos através - no sentido daquilo que corta trespassando - da criação de outros acontecimentos: expressão de vontade, de força, contra-exigüidade de experiências. O sujeito aqui, para além da identidade do termo -

\footnotetext{
${ }^{201}$ Cf. FOUCAULT, M. Les techinique de soi. In. Dits et Écrits IV, № 363, 1988, p. 788.

${ }^{202}$ FOUCAULT, M. À propos de la généalogie de l'éthique: un aperçu du travail en cours. Dits et Écrits IV, $\mathrm{N}^{\circ}$ 326, 1984, p.392.

${ }^{203}$ FOUCAULT, M. História da sexualidade II: o uso dos prazeres, p.15 e 27.
} 
“existem menos vocábulos que designam do que coisas a designar" -, pode muito bem representar aquela "vacância absoluta do ser que é necessário investir, controlar e preencher pela invenção pura". Então, poderíamos nos dar conta de que é ainda uma imagemexperiência mais ou menos inescapável, imponderável, inefável, de porosidade completamente aberta, um acontecimento pleno de vir-a-ser o lance da aposta. Voltaríamos assim à história e ao palco do mundo e ali, entre a cena que sempre se deslinda e o rosto que se desvanece, como, na orla do mar um rosto de areia, veríamos nós mesmos como sujeitos, todavia em "imagem invisivelmente visível, perceptível mas não decifrável, dada num clarão e sem leitura possível, presente numa irradiação que rechaça o olhar"204.

\footnotetext{
${ }^{204}$ As citações aqui seguem a seguinte ordem: FOUCAULT, M. Raymond Roussel, p.13 e 48.
} 


\title{
CONCLUSÃO
}

\section{Meu modo de não ser mais o mesmo é, por definição, a parte mais singular do que sou.}

\author{
Michel Foucault, \\ Pour une morale de l'inconfort
}

Se Jean Hyppolite chegou a constatar que "a filosofia francesa" - e Foucault secundaria: por conseguinte a filosofia ocidental - "sempre desprezou e desconheceu a história"1, toda uma reflexão e trajetória de pensamento, ao longo das linhas em que se desenvolveram e ganharam emergência, atestarão os sinais contrários daquela disposição. É assim a perspectiva foucaultiana: nada pode ser pensado ou concebido fora da história.

Em nosso exame, tomamos a subjetividade como um intensificador deste empreendimento pautado por campos de situações históricas de estratos diversificados e heterotopológicos. O intuito primordial foi o de fazer reconhecer a importância que o sujeito ocupa na trajetória singular e transmutante deste pensador, que continua a nos incitar a reconhecer, nas distintas análises possíveis de serem feitas da própria história, os nossos processos incontornáveis de transformação. Foi para isto que assumimos a posição de não nos limitarmos no lançamento de uma hipótese interpretativa meramente condutora da obra. Mas procuramos nos debruçar em certas variantes dos traços que julgamos os mais pertinentes com relação à posição que a temática da subjetividade ali pudesse ocupar. Para tanto, levamos em consideração as formas de abordagem que não apenas seriam capazes de modificar o entendimento dispensado à questão, como também assinalamos para a sua superação constante, visando a ultrapassar problematizações que, no fundo, sublinharam toda tomada de destruição do sujeito como um falso objeto, ou melhor, como uma substância preconcebida ou às margens das condições de transformação histórica.

Se por vezes sujeito e subjetividade se confundiam, um termo sendo tomado pelo outro, na verdade, isso se deveu ao fato de existir aí uma problemática crucial no pensamento de Foucault que se apresenta como uma radicalização e inovação que se desposa com a

\footnotetext{
${ }^{1}$ HYPPOLITE, J. Histoire et Existence. In. Figures de la pensée philosophique. Tomo II. Paris: Quadriage/PUF, 1971, p.973.
} 
condição inseparável de que a constituição de um sujeito na história é tão devedora das condições de subjetividade nas quais ele está implicado. Os feixes diferentes nos processos de transformação de subjetividade efetivam, garantindo e franqueando, a posição de determinados sujeitos. Toda e qualquer mudança no foco interpretativo histórico é, inescapavelmente, uma nova tensão que se engendra para o sujeito.

Foi decisiva, assim, a nossa insistência no âmbito das relações de forças. Das experiências fundamentais numa cultura sob o regime condicionante das ordens mais distintas que estão instaladas na história - de nosso destino à vontade de saber, de poder e de verdade até aos pontos das experiências-limites, é o jogo incessante entre a força que opera no sentido da sujeição com aquela a afrontar as suas estratégias e táticas, visando a dessujeição, que um fio vermelho emerge apesar de se dispor pelos veios de canais descontínuos. Se vimos isto na obra de Foucault, é porque acompanhamos o próprio diagnóstico que ele fez da história: o de sua descontinuidade. E, quanto a isto, já não pudemos assegurar, nem para nós mesmos, um conforto didático que fosse capaz de criar pontes a contento. Nós, enquanto sujeito que somos, também ficamos perdidos nesta trama. Se não nos achamos totalmente ali, talvez, seja pela própria intenção da força de um pensamento que nos projeta à busca constante pelos fios que nunca serão ligados. Esta pequena armadilha já é o sintoma mais elevado da incompletude do próprio sujeito. Aliás, nisto está o sinal do que tentamos chamar de coerência na obra.

A própria relação que buscamos estabelecer entre arqueologia e genealogia tentou mostrar isto desde a pauta metodológica de Foucault. Criar ferramentas singulares e específicas de análises só atestou a fundamental necessidade de repor, às tomadas de compreensão do sujeito, outras perspectivas de seus contornos e também de seus modos de apreensão. Em nosso entendimento, este movimento faz parte complexa de um campo situacional que definitivamente nos faz reconhecer as interdições que se colocam a todo tipo de pensamento inclinado à fixidez ou entregue aos pressupostos definidos de antemão, paralisando as vias significado-significante, que tentam fazer do homem um objeto de análise. Com efeito e por isto mesmo é que a cautela teve de assumir lugar privilegiado na organização e posição de qualquer discurso que pretendesse tomar o pensamento de Foucault como obstinada resposta aos problemas atuais. Não se deve tratar de receituários - como se deve fazer - prognósticos incisivos, itens básicos para transformação individual, social, postulados modificadores, enfim, Foucault sob a demanda de uma indústria cultural que incita saídas banais para velhos problemas. A isto tentamos não reduzir todo campo de problemática, ou seja, a um tipo de bandeira incitante. Aqui, talvez, entendemos o próprio 
efeito da crítica enquanto operador tanto do conteúdo quanto das manobras possíveis de serem extraídas deste conteúdo.

Esta postura, a nosso ver, torna-se fundamental para a apreensão e depuração dos trabalhos de Foucault como ferramenta. A alusão é no sentido mesmo da multiplicidade que deve ser assumida e invocada como instrumento a ser usado em infinitas conjugações, possibilidades e frentes de prospecção, análise e atuação do pensamento, até mesmo para que as práticas humanas sejam repensadas até nas cadeias invisíveis de seus acontecimentos. Pois, em seu cerne, se somos obrigados a assumir uma posição, a história dos homens sempre será a de uma força que se produziu voltada para eles, sempre refundada em sua criatividade sujeitante, a se pôr contra outros tipos de forças que enfrentam tais composições na expectativa de nos desviar de qualquer tipo de destino absoluto. $\mathrm{Na}$ orla de nossos limites históricos, uma linha sempre quer se mover em outra direção. Saber aproveitar o seu instante, o movimento fugidio, apreender-nos nesta experiência, irá tratar-se de nos colocarmos no registro da dessujeição antes que ela seja englobada novamente por um registro normatizantenormalizante, sob exercícios de dominação, ao grande litoral da norma-verdade. Eis aí a demanda incessante e o lugar que ocupam as lutas, as resistências, as contra-condutas, a produção de acontecimentos singulares, toda série possível de engendramento para um governo de si - o sujeito da ação criativa. Também eis aí um quadro de exigências para o não estiolamento do sujeito, um reposicionar-se perante toda destinação de passividade a que somos submetidos continuamente, uma cartografia a ser traçada pela descoberta, pela interrogação da própria atualidade. Enfim, para nós, a temática da história e subjetividade em Michel Foucault deve resultar em um posicionamento que, apesar de diagnosticar nossos limites, os campos de homogeneidade a que estamos e somos submetidos, não redunda nem implica, de agora em diante, em dizer ou pensar ou comportar-se do mesmo modo. A história, por estar sempre nas frinchas das dobras de forças, autoriza o estatuto incoativo do sujeito: sob ela, tudo pode recomeçar. "Experiência com... mais que engajamento em...", diria Foucault ${ }^{2}$.

Mas, então, para onde devemos nos avançar? Em boa medida, ao dissolvermos a referência axiológica da ontologia do sujeito por intermédio da ênfase política na qual ele se constitui e está situado, constatação ulterior de seu fatum histórico, sub-repticiamente emergimos a condição de instalação, de uma vez por todas, da questão da atualidade para o sujeito. Dado a existir já em um campo de forças, a sua atualidade, como se colocar por ela a

\footnotetext{
${ }^{2}$ FOUCAULT, M. Pour une morale de l'inconfort. In. Dits et Écrits III, N² 266, 1979, p.785.
} 
fim de forjar pelos pontos minúsculos do acontecimento uma dimensão dissímel para esta atualidade, logo, para si mesmo? Em termos mais diretos: em que medida o pensamento de Foucault ainda nos auxilia a pensar, nos localizar e nos mover na atualidade? Parece-nos ser esta a indagação pulsante e crucial de todo este eixo que não se furta a se colocar entre história e subjetividade o próprio papel para a filosofia enquanto exercício de pensamento ou ensaio aberto enquanto um tipo de "ascese" no pensamento, um exercício de si como experiência modificadora de si no jogo da verdade, ou seja, nos domínios da própria atualidade ${ }^{3}$. Assim, fazer pensar por intermédio de Foucault seria fazer agir.

Ora, se foi no âmbito da função e do estado a ocupar que procuramos circunscrever toda a constituição do sujeito, ao nos aproximarmos da inventividade que subjaz à vida como ensaio, então podemos sustentar que, no presente, o sentido atual do pensamento de Foucault nos impulsiona para a ampliação de discursos e práticas, pontos de contatos entre arqueologia e genealogia, que trabalharão no sentido de confrontar todas as séries de verdade para as quais estávamos destinados. Tanto a ordem do saber, do poder quanto o metrônomo de toda moral vigente, articulações das engrenagens que nos conduzem no Ocidente, podem, assim, sofrer modificações pelo viés de novas estratégias e táticas para as quais somos convocados a pensar as ações de torção destes eixos que predominam e articulam a vida. Temos um campo aberto de atuação para o sujeito diante da história, atuação prefigurada por suas ações e escolhas que convergem para o seu próprio governo: é a possibilidade mais próxima na história humana para se estabelecer pontos de resistência em toda rede de poder.

Dobrar as forças é procurar nos instalar em um outro nível de atualidade, ou seja, em um espaço onde o pensamento e o acontecimento sejam dados sob condições de constituição permanente em criatividade, invenção, arte como técnica de si, ensaio como fluxo aberto nos jogos de verdade, instabilidade enquanto dissolução de forças de coerções. Ponderar as formas de atual constituição de nossa experiência na contemporaneidade é forjar, inevitavelmente, uma tensão nos campos das epistemologias e dos dispositivos que demarcam o que é possível nomear, pensar e agir. Entrar nestes desvãos seria não falar, nem agir ou pensar a partir do interior das regras do mesmo. É cortar por todos os lados e direções a cultura da homogeneização - a nossa câmara ontológica invertida - por intermédio daquilo

\footnotetext{
${ }^{3}$ Conforme coloca Foucault na História da sexualidade II: o uso dos prazeres, p.13, lembramos o contexto que julgamos, além de belo, importante para o momento: "Existe sempre algo de irrisório no discurso filosófico quando ele quer, do exterior, fazer a lei para os outros, dizer-lhes onde está a sua verdade e de que maneira encontrá-la, ou quando pretende demonstrar-se por positividade ingênua; mas é seu direito de explorar o que pode ser mudado, no seu próprio pensamento, através de um exercício de um saber que lhe é estranho. $\mathrm{O}$ 'ensaio' - que é necessário entender como experiência modificadora de si no jogo da verdade, e não como apropriação simplificadora de outrem para fins de comunicação - é o corpo vivo da filosofia, se, pelo menos, ela for ainda hoje o que era outrora, ou seja, uma 'ascese', um exercício de si, no pensamento".
} 
que Guattari denominou de microrevolução, mas que também poderíamos chamar de atitudelimite e experimental, singularização, contra-conduta, experiência de força autóctone.

Seja como for, julgamos que as pesquisas vindouras atinentes à herança foucaultiana devem avançar por toda série de problemáticas que ainda persistirão ao longo desta mesma dobra de nossa experiência cultural e que, por isto mesmo, deve ser levada em consideração com mais vigor. Desde a fértil pastoralização da existência que se dissemina no fechamento das relações sociais ou de sua privatização e, por conseguinte, em seu empobrecimento dos repertórios de convivência humana atestada pelo universo dos personal, coaching, guias de consciência de todas as espécies, que banham a sociedade com as diretrizes individuais de condução, de comportamento, de estilização, de pensamento, até a presença marcante de um biopoder que encerra a capacidade de controlar a vida em sua totalidade, tudo isto nos marca do modo indelével. Quanto a este, é preciso denunciar a perversidade escandalosa que, em nome das melhorias via as regulamentações político-sociais, em nome de todos, o que se estabelece é um jogo de forças cujas regras autorizam o que se pode ou não para a vida. $\mathrm{O}$ biopoder/biopolítica têm introduzido na sociedade, nos domínios da existência: "um corte entre o que é bom para vida e o que deve morrer" ${ }^{\wedge}$. O desafio, ao pensarmos em termos de estratégia histórica para o sujeito, para a produção de outras subjetivações, é não se tornar população, indivíduo abstraído neste grande sujeito coletivo. A questão é saber, de um lado, como é possível se interpor aos padrões atuais verdadeiros de saúde, beleza, sucesso, raça, de felicidade, do eudemonismo vivo presente no sangue do consumismo, do padrão da boa forma.

Mas, de outro lado, é urgente trazer para a pauta das reflexões sobre a atualidade o aspecto destrutivo da vida pelo uso e aplicação da força biopolítica concernente às guerras. Temos de fazer notar que os atuais movimentos beligerantes são, maciçamente, fundados e articulados em nome do biopoder, arrefecendo, assim, uma certa lógica de um establishment: controle daquilo que se julga melhor para uma nação, em nome de um jogo de verdade, atingindo, transformando, deformando, assim, inúmeras vidas; nisto não mais importa quaisquer idiossincrasias culturais, religiosas e até mesmo econômicas. A guerra em nome da planificação planetária. O biopoder traz, neste prisma, a questão do racismo, bioética, do controle tecno-científico da concepção das coisas matérias, objetificando o ser humano. Coloca em cena a angústia dos refugiados, desta multidão invisível que se move às custas das conseqüências de uma certa gestão da vida. Tal cenário também faz emergir as políticas de

\footnotetext{
${ }^{4}$ FOUCAULT, M. Em defesa da sociedade, p.304.
} 
assassínio indireto, ou seja, daquele nível de vida no qual os sujeitos são expostos, a cada instante, às agressões do medo, da exposição contínua à ameaça de morte, à expulsão, à rejeição e à exclusão social.

Salta aos olhos, sob o peso de tal perspectiva, que é do ponto de vista de uma história crítica do pensamento que somos convocados a nos colocar. Esta história cuja força primordial é modificar o nosso entendimento acerca dos objetos existentes e das práticas possíveis que advém de nossa relação com estes mesmos objetos. "Quem somos nós neste exato instante? Qual é, portanto, o momento tão frágil em que podemos desprender nossa identidade e que será levada com ele?" 5 . É a dissolução de um Eu integrado a todo tipo de força constritora que nos faz pensar na constituição histórica constante da subjetividade. Em nosso exame, portanto, o que persiste é esta tarefa umbilical que não mais desloca o sujeito para fora de sua dimensão histórica. Este tipo de labeur infini sobre nós mesmo, que a própria obra de Michel Foucault persiste em testemunhar, é o que nos situa nesta trama inesgotável de possibilidade de pensarmos, agirmos e sermos entre a história já circunscrita, a de nosso vir-aser e de toda possibilidade de nossa subjetividade: nossas incontornáveis experiências com as finitudes. De que espécie de devir histórico, então, somos capazes?

\footnotetext{
${ }^{5}$ FOUCAULT, M. Pour une morale de l'inconfort. In. Dits et Écrits III, Nº 266, 1979, p.785.
} 


\section{BIBLIOGRAFIA}

\section{OBRAS DE MICHEL FOUCAULT}

FOUCAULT, M. Histoire de la folie à l'âge classique (1972). Paris: Gallimard, 2000.

. O nascimento da clínica. Trad. Roberto Machado. 6. ed. Rio de Janeiro: Forense Universitária, 2004.

Raymond Roussel. Trad. Manoel Barros da Motta e Vera Lucia

Avellar Ribeiro. Rio de Janeiro: Forense Universitária, 1999.

Paulo: Martins Fontes, 1999.

As palavras e as coisas. Trad. Salma Tannus Muchail. 8. ed. São . Nietzsche, Freud \& Marx. Trad. Jorge Lima Barreto. São Paulo:

Princípio, 1997.

A ordem do discurso. Trad. Laura Fraga de Almeida Sampaio.

11.ed. São Paulo: Edições Loyola, 2004.

. A arqueologia do saber. Trad. Luiz Felipe Baeta Neves. 6.ed. Rio de Janeiro: Forense Universitária, 2002.

Le pouvoir psychiatrique - cours au Collège de France (19731974). Paris: Gallimard/Seuil, 2003.

. Os anormais - curso no Collège de France (1974-1975). Trad.

Eduardo Brandão. São Paulo : Martins Fontes, 2001.

. Em defesa da sociedade - curso no Collège de France (1975-1976). Trad.

Maria Ermantina Galvão. São Paulo: Martins Fontes, 2002.

. Vigiar e punir. Trad. Ligia M. Pondé Vassalo. 5.ed. Petrópolis:

Vozes, 1987.

. História da Sexualidade I: a vontade de saber. Trad. Maria Thereza da Costa Albuquerque. 8.ed. Rio de Janeiro: Graal, 1998.

. Sécurité, territoire, population - cours au Collège de France (1977-1978). Paris: Gallimard/Seuil, 2004.

. Naissance de la biopolitique - cours au Collège de France (1978-

1979). Paris: Gallimard/Seuil, 2004. 
A hermenêutica do sujeito - Curso no Collège de France (19811982). Trad. Márcio Alves da Fonseca e Salma Tannus Muchail. São Paulo : Martins Fontes, 2004.

. História da Sexualidade II: o uso dos prazeres. Trad. Maria Thereza da Costa Albuquerque. 8. ed. Rio de Janeiro: Graal, 1998.

. História da Sexualidade III: o cuidado de si. Trad. Maria Thereza da Costa Albuquerque. 10. ed. Rio de Janeiro : Graal, 1998.

. Dits et Écrits I - 1954-1975. Paris: Gallimard, 2001.

. Dits et Écrits I - 1954-1969. Paris: Gallimard, 1994.

. Dits et Écrits III - 1976-1979. Paris: Gallimard, 1994.

. Dits et Écrits IV - 1980-1988. Paris : Gallimard, 1994.

- Microfísica do poder. Trad. Roberto Machado. 12.ed. Rio de

Janeiro : Graal, 1996.

. Resumo dos cursos de Collège de France (1970-1982). Trad. Andrea Daher. Rio de Janeiro: Jorge Zahar Editor, 1997.

. What is critique? In: SCHMIDT, James (Ed.). What is

Enlightenment? Eighteenth-Century answers and Twentieth-Century questions. Berkeley: University of California Press, 1996. p. 382-398.

FOUCAULT, M; CHOMSKY, N. De la nature humaine: justice contre pouvoir. In. ELDERS, F. (Org.). Sur la nature humaine: compreendre le pouvoir. Interlude. Bruxelles: Les Editions Aden, 2006.

\section{OBRAS DE COMENTADORES}

ADORNO, Francesco P. La tâche de l'intellectuel: le modèle socratique. In: LÉVY, C.; GROS, F. (Orgs.). Foucault et la philosophie antique. Paris: Éditions Kimé, 2003. p.35-59.

ADORNO, Sérgio. Foucault, a lei e o direito. In : ALVAREZ, Marcos Cesar et al (Orgs.). $O$ legado de Foucault. São Paulo: Editora da UNESP, 2006, p. 201-222.

AGAMBEN, Giorgio. Homo sacer: o poder soberano e a vida nua I. Trad. Henrique Burigo. Belo Horizonte: Editora UFMG, 2002.

ARTIÈRES, Philippe. Dire l'actualité. Le travail de diagnostic chez Michel Foucault. In: LÉVY, C.; GROS, F (Orgs.). Foucault et la philosophie antique. Paris: Éditions Kimé, 2003. p. 11-33. 
BALIBAR, Étienne. Foucault et Marx: l'enjeu du nominalisme. In: Michel Foucault philosophe. Rencontre internationale Paris 9, 10, 11 janvier 1988. Paris: Éditions du Seuil, 1989. p. 54-77.

BAUDRILLARD, J. Esquecer Foucault. Rio de Janeiro: Rocco, 1984.

BERNAUER, J; RASMUSSEN, D. The Final Foucault. Londres: MIT Press, 1991.

BILLOUET, Pierre. Foucault. São Paulo: Estação Liberdade, 2003.

BORHEIM, Gerd. O Sujeito e a Norma. In: Ética. São Paulo: Companhia das Letras, 1992. 242-260p.

BUTLER, Judith. Qu'est-ce que la critique? Essai sur la vertu selon Foucault. In: GRANJON, Marie-Christine (Org.). Penser avec Michel Foucault: Théorie critique et pratiques politiques. Paris: Karthala, 2005. p. 75-101.

CANGUILHEM, George. Mort de l'homme ou épuisement du cogito? Critique. Paris: Éditions de Minuit, T. XXIV, n. 242, p. 599-618, juillet 1967.

CERTEAU, Michel de. Histoire et psychanalyse: entre science et fiction. Paris: Gallimard, 1987.

CLEGG, S. Weber and Foucault: social theory for the study of organizations. In. Organization Articles. London, Vol. 1 (1): p.149-178.

CHARTIER, Roger. Au bord de la falaise: l'histoire entre certitudes et inquiétude. Paris: Albin Michel, 1998.

DAVIDSON, Arnold I. Archaeology, Genealogy, Ethics. In: HOY, Couzens David (Ed.). Foucault: A Critical Reader. New York: Basil Blackwell, 1987. p.221-233.

. Le gouvernement de soi et des autres. In: DAVIDSON, A. I.; GROS, F. (Orgs). Michel Foucault. Philosophie Anthologie. Paris: Gallimard, 2004. p.651-664.

. Régimes de pouvoir et régimes de vérité. In: DAVIDSON, A. I.; GROS, F. (Orgs). Michel Foucault. Philosophie Anthologie. Paris: Gallimard, 2004. p. 381-392.

DELEUZE, Gilles. Foucault. Paris: Éditions de Minuit, 1986.

Editora 34, 2006.

. Conversações 1972-1990. Tradução de Peter Pál Pelbart. São Paulo:

. Qu'est-ce qu'un dispositif? In: Michel Foucault philosophe. Rencontre internationale Paris 9, 10, 11 janvier 1988. Paris: Éditions du Seuil, 1989. p. 185-195.

. Écrivain non: un nouveau cartographe. Critique. Paris: Éditions de Minuit, T. XXXI, n. 343, p.1207-1227, décembre 1975. 
DEFERT, Daniel. Glissements progressives de l'oeuvre hors d'elle-même. In: FRANCHE, D. et al (Orgs.). Au risque de Foucault. Paris: Éditions du Centre Pompidou, 1997. p.151-160.

. Le « dispositif de guerre » comme analyseur des rapports de pouvoir. In: ZANCARINI, Jean-Claude (Org.). Lectures de Michel Foucault, v.1. A propos de "il faut défendre la société ». Lyon: ENS Éditions, 2001. p.59-65

DESCOMBES, Vincent. Le Même et L'autre - quarente-cinq ans de Philosophie Française (1933-1978). Paris, Les Éditions Minuit, 1979.

Gallimard, 2004.

Le complement de sujet: enquête sur le fait d'agir de soi-même. Paris:

. Desire and Pleasure. In: DAVIDSON, Arnold I. (Ed.). Foucault and his interlocutors. Chicago: Chicago Press, 1997. p.183-192.

DOSSE, François. História do Estruturalismo. V.2. O canto do cisne, de 1967 a nossos dias. Campinas: Editora da Unicamp, 1994.

- A história à prova do tempo: da história em migalhas ao resgate do sentido. Trad. Ivone Castilho Benedetti. São Paulo: Editora UNESP, 1999.

DREYFUS, H.; RABINOW, P. Michel Foucault: Uma trajetória filosófica - para além do estruturalismo e da hermenêutica. Trad. Vera Porto Carrero. Rio de Janeiro: Forense Universitária, 1995.

. Habermas et Foucault : qu'est-ce que l'age d'homme ? Critique - Michel Foucault : du monde entier. Paris: Éditions de Minuit, t. XLII, n. 471-472, p.857-872, aoûtseptembre 1986.

ÉVRARD, Franck. Michel Foucault et l'histoire du sujet en Occident. Paris: BertrandLacoste, 1995.

EWALD, François. Foucault: a norma e o direito. Lisboa: Vega, 1993.

. Foucault et l'actualité. In. FRANCHE, D. et al (Orgs.). Au risque de Foucault. Paris: Éditions du Centre Pompidou, 1997. p.203-212.

. Michel Foucault et la norme. In: GIARD, Luce (Dir.). Michel Foucault: Lire l'oeuvre. Grenoble: Jérôme Millon, 1992. p. 201-221.

FARGE, Arlette. Des lieux pour l'histoire. Paris: Éditions du Seuil, 1997.

FERRY, L. e RENAUT, A. Pensamento 68: ensaio sobre o anti-humanismo contemporâneo. São Paulo: Editora Ensaio, 1988.

FIMIANI, Mariapaola. Foucault et Kant: critique, clinique, éthique. Paris: L'Harmattan, 1998. 
Le véritable amour et le souci commun du monde. In: LÉVY, C.; GROS, F. (Orgs.). Foucault et la philosophie antique. Paris: Éditions Kimé, 2003. p. 87-127.

FONSECA, Márcio A. Michel Foucault e a constituição do sujeito. São Paulo: Educ, 1995.

GLÜCKSMANN, André. Le nihilisme de Michel Foucault. In: Michel Foucault philosophe. Rencontre internationale Paris 9, 10, 11 janvier 1988. Paris: Éditions du Seuil, 1989. p. 395398.

GROS, Frédéric. Situations de cours. In. L'herméneutique du sujet Cours au Collège de France. 1981-1982. Paris: Gallimard, 2001.

. La parrhêsia chez Foucault. In: LÉVY, C.; GROS, F. (Orgs.). Foucault et la philosophie antique. Paris: Éditions Kimé, 2003. p. 155-166.

. Michel Foucault, une philosophie de la vérité. In: DAVIDSON, A. I.; GROS, F. (Orgs.). Michel Foucault. Philosophie Anthologie. Paris: Gallimard, 2004. p. 1125.

HABERMAS, J. Une flèche dans le coeur du temps présent. Critique - Michel Foucault : du monde entier. Paris: Éditions de Minuit, t. XLII, n. 471-472, p.794-799, août-septembre 1986.

HADOT, Pierre. Un dialogue interrompu avec Michel Foucault - convergences et divergences. In: Exercices spirituels et philosophie antique. Paris: Albin Michel, 2002. p. 307-311.

HONNETH, Axel. Foucault et Adorno: deux formes d'une critique de la modernité. Critique - Michel Foucault : du monde entier. Paris: Éditions de Minuit, t. XLII, n. 471-472, p.800815, août-septembre 1986.

. Foucault's theory of society: a systems-theoretic dissolution of the Dialectic of Enlightenment. In: KELLY, Michael. Critique and Power: recasting the Foucault/Habermans debate. Massachusetts/London: MIT Press, Cambridge, 1994. p.157182.

LE GOFF, Jacques. Foucault et la nouvelle histoire. In. FRANCHE, D. et al (Orgs.). Au risque de Foucault. Paris: Éditions du Centre Pompidou, 1997. p.129-139.

LEBRUN, Gérard. Passeios ao léu. Ensaios. São Paulo: Brasiliense, 1983.

. Note sur la phénoménologie dans Les Mots e les Choses. In: Michel Foucault philosophe. Rencontre internationale Paris 9, 10, 11 janvier 1988. Paris: Éditions du Seuil, 1989. p. 33-52.

LÉVY, C.; GROS, F. Introduction: le courage de la vérité. In: LÉVY, C.; GROS, F. (Orgs.). Foucault et la philosophie antique. Paris: Éditions Kimé, 2003. p.

MACHADO, Roberto. Archéologie et épistémologie. In: Michel Foucault philosophe. Rencontre internationale Paris 9, 10, 11 janvier 1988. Paris: Éditions du Seuil, 1989. p. 1531 . 
2000.

. Foucault, a filosofia e a literatura. Rio de Janeiro: Jorge Zahar Editor,

MARIETTI, Angele K. Michel Foucault: archéologie et généalogie. Paris: Grasset, 1985.

MARTON, Scarlett. Extravagâncias: ensaios sobre a filosofia de Nietzsche. São Paulo: Discurso Editorial, 2000.

MUCHAIL, Salma T. Da Arqueologia à Genealogia. Acerca do(s) propósito(s) de Michel Foucault. Cadernos PUC. São Paulo, n.32, p.31-46, 1988.

. O Mesmo e o Outro: Faces da história da loucura. In: MARIGUELA, M. (Org.). Foucault e a Destruição das evidências. Piracicaba: Editora Unimep, 1995. p.29-42.

O'NEILL, J. The disciplinary society: from Weber to Foucault. In. The British Journal of Sociology, v. XXXVII, n.1. p.42-60.

ORTEGA, Francisco. Amizade e Estética da Existência em Foucault. Rio de Janeiro: Graal, 1999.

POSTER, Mark. Foucault, le présent et l'histoire. In: Michel Foucault philosophe. Rencontre internationale Paris 9, 10, 11 janvier 1988. Paris: Éditions du Seuil, 1989. p. 354-370.

POTTE-BONNEVILlE, Mathieu. Michel Foucault, l'inquiétude de l'histoire. Paris: PUF, 2004.

PRADEAU, J-F. Le sujet ancien d'une éthique moderne. À propos des exercices spirituels anciens dans l'Histoire de la sexualité de Michel Foucault. In. GROS, F. (Org.). Foucault, le courage de la vérité. Paris: PUF, 2002, p.131-154.

RAJCHMAN, John. Foucault: a liberdade da filosofia. Trad. Álvaro Cabral. Rio de Janeiro: Jorge Zahar Editor, 1987.

. Foucault: 1'éthique et l'oeuvre. In: Michel Foucault philosophe. Rencontre internationale Paris 9, 10, 11 janvier 1988. Paris: Éditions du Seuil, 1989. p. 249259.

REVEL, Jacques. Machines, stratégies, conduits: ce qu'entendent les historiens. In. FRANCHE, D. et al (Orgs.). Au risque de Foucault. Paris: Éditions du Centre Pompidou, 1997. p.109-126.

REVEL, Judith. Le vocabulaire de Foucault. Paris: Ellipses, 2002.

. Expériences de la pensée - Michel Foucault. Paris : Bordas, 2005.

. La pensée verticale: une éthique de la problématisation. In: LÉVY, C.;

GROS, F. (Orgs.). Foucault et la philosophie antique. Paris: Éditions Kimé, 2003. p.63- 86. 
SERRES, Michel. The geometry of the incommunicable: madness. In: DAVIDSON, Arnold I. (Ed.). Foucault and his interlocutors. Chicago: Chicago Press, 1997. p.36-56.

VÉDRINE, Hélène. Le sujet éclaté. Paris: Grasset, 2000

VEYNE, Paul. The final Foucault and his ethics. In: DAVIDSON, Arnold I. (Ed.). Foucault and his interlocutors. Chicago: Chicago Press, 1997. p. 225-233.

. Como se escreve a história e Foucault revoluciona a história. Brasília:

Editora UNB, 1998.

. Foucault et le dépassement (ou achievement) du nihilisme. In: Michel Foucault philosophe. Rencontre internationale Paris 9, 10, 11 janvier 1988. Paris: Éditions du Seuil, 1989. p. 399-404.

WAHL, François. Hors ou dans la philosophie? L'Archeologie du savoir, L'Usage des plaisirs, Le Souci de soi. In: Michel Foucault philosophe. Rencontre internationale Paris 9, 10, 11 janvier 1988. Paris: Éditions du Seuil, 1989. p. 85-100.

ZARKA, Yves Charles. Figures du pouvoir: études de philosophie politiques de Machiavel à Foucault. Paris: PUF, 2001.

\section{OUTRAS OBRAS}

ADORNO, T. W.; HORKHEIMER, M. Dialética do Esclarecimento - fragmentos filosóficos. Trad. Guido Antonio de Almeida. Rio de Janeiro: Jorge Zahar Editor, 1985.

BACHELARD, G. La formation de l'esprit scientifique. Paris: Vrin, 2000.

BAUDELAIRE, C. As flores do mal. Edição bilíngüe. Trad. Ivan Junqueira. Rio de Janeiro: Nova Fronteira, 1985.

BENTHAM, J. O panóptico. Trad. Tomaz T. da Silva. São Paulo: Autêntica, 2000.

BORGES, Jorge L. O tempo. In: Obras completas IV - 1975-1988. Trad. Maria Carolina de Araujo e Jorge Schwartz. São Paulo: Editora Globo, 1999.

CAILlE, A. et al. História crítica da filosofia moral e política. Trad. sob direção de Manuel Costa Freitas. Lisboa/São Paulo: Editorial Verbo, 2005.

CANGUILHEM, G. O normal e o patológico. Trad. Maria Thereza R. de Carvalho Barrocas. 6. ed. rev. Rio de Janeiro: Forense Universitária, 2006.

CLAUSEWITZ, K. Von. De la guerre. Paris: Les Éditions de Minuit, 2006. 
DELEUZE, G.; GUATTARI, F. Mil Platôs: capitalismo e esquizofrenia. V. 1. Trad. Aurélia Guerra Neto e Celia Pinto Costa. São Paulo: Editora 34, 2004.

DELUMEAU, J. O pecado e o medo: a culpabilização no Ocidente. Trad. Álvaro Lorencini. Bauru: Edusc, 2003.

DESCARTES, R. Obras incompletas. Coleção “Os Pensadores”. Trad. J. Guinsburg e Bento Prado Júnior. 3.ed. São Paulo: Abril Cultural, 1983.

DUMÉZIL, G.; BÉGARIE-COUTAU, H. Mythes et dieux des Indo-Européens. Paris: Flammarion, 1999.

ELIOT, T. S. Poesia. In: Obras Completas. Trad. Ivan Junqueira. São Paulo: Editora Arx, 2004.

FREUD, S. O mal-estar na civilização. In: Obras Completas de Sigmund Freud. Trad. José Octávio de Aguiar Abreu. v. XXI. Rio de Janeiro: Imago, 1974. p. 81-171

GUATTARI, F. e ROLNIK, S. Cartografias do desejo. 7. ed. rev. Petrópolis: Vozes, 2005.

HOBBES, T. Obras incompletas. Coleção "Os Pensadores”. Trad. João Paulo Monteiro e Maria Beatriz Nizza da Silva. São Paulo: Nova Cultural, 1999.

HYPPOLITE, J. Figures de la pensée philosophique. Paris: Quadrige/PUF, 1991.

ITAPARICA, André Luis M. Nietzsche: estilo e moral. São Paulo: Discurso; Editora Unijuí, 2002.

KANT, I. Idéia de uma história de um ponto de vista cosmopolita. Trad. Ricardo R. Terra e Rodrigo Naves. São Paulo: Martins Fontes, 2003.

Resposta à pergunta: Que é "Esclarecimento"? Trad. Floriano de Sousa Fernandes. 3. ed. In. Textos selecionados. Petrópolis: Vozes, 2005. P. 63-71.

KLOSSOWSKY, P. Nietzsche e o Círculo Vicioso. Trad. Hortencia S. Lencastre. Rio de Janeiro: Pazulin, 2000.

LA BOÉTIE, Etienne de. Discurso da servidão voluntária. Trad. Laymert Garcia dos Santos. 4. ed. São Paulo: Editora Brasiliense, 1987.

LE GOFF, Jacques. A recusa do prazer. In. Amor e sexualidade no Ocidente. Edição especial da revista L'Histoire/Seuil. Trad. Anna Maria Capovilla et al. Porto Alegre : L\&PM, 1992, p.150-162.

LÉVI-STRAUSS, C. Obras incompletas. Coleção “Os Pensadores”. Trad. Eduardo P. Graeff, Inácia Canelas, Malcom Bruce Corrie. São Paulo: Abril Cultural, 1980.

MARCUSE, H. Eros e civilização: uma interpretação filosófica do pensamento de Freud. Trad. Álvaro Cabral. 8. ed. Rio de Janeiro: Guanabara/Koogan, s/d. 
MATOS, Olgária C. F. Para uma crítica do presente. Revista de Antropologia (USP). São Paulo, v. 44, n. 2, p. 259-267, 2001.

MERLEAU-PONTY, M. A prosa do mundo. Trad. Paulo Neves. São Paulo: Cosac \& Naify, 2002.

MY SECRET LIFE. Récit de la vie sexuelle d'un Anglais de l'époque victorienne. Paris: Éditions Les Formes du Secret, 1977.

NIETZSCHE, F. Humano, demasiado humano. Trad. Paulo César de Souza. São Paulo: Companhia das Letras, 2002.

Genealogia da moral. Trad. Paulo César de Souza. 5.ed. São Paulo: Companhia das Letras, 2001.

SANTO AGOSTINHO. Confissões. Trad. Maria Luiza Jardim Amarante. São Paulo: Paulinas, 1984.

SKINNER, B. F. Ciência e comportamento humano. Trad. João Carlos Todorov e Rodolph Azzi. 5. ed. São Paulo: Martins Fontes, 1981. 